Sylvia Adriana Dobry Pronsato

\title{
Para quem e com quem: ensino de Arquitetura e Urbanismo
}

Tese apresentada como experiência parcial para obtenção do título de doutor em Arquitetura e Urbanismo

FAU-USP

Área de concentração projeto, espaço e cultura

Orientadora Maria Ângela Faggin Pereira Leite

São Paulo 2008 
AUTORIZO A REPRODUÇÃO E DIVULGAÇÃO TOTAL OU PARCIAL DESTE TRABALHO, POR QUALQUER MEIO CONVENCIONAL OU ELETRÔNICO, PARA FINS DE ESTUDO E PESQUISA, DESDE QUE CITADA A FONTE.

ASSINATURA:

E-MAIL: sydobry@gmail.com

Pronsato, Sylvia Adriana Dobry

P965p Para quem e com quem: ensino de Arquitetura e Urbanismo / Sylvia Adriana Dobry Pronsato. - - São Paulo, 2008.

319 p. : il.

Tese (Doutorado - Área de Concentração: Projeto, Espaço e Cultura) - FAUSP.

Orientadora: Maria Ângela Faggin Pereira Leite

1.Arquitetura (Estudo e ensino) - Brasil 2.Arquitetura (Estudo e ensino) - Argentina 3.Urbanismo (Estudo e ensino) Brasil 4.Urbanismo (Estudo e ensino) - Argentina I.Título

CDU $72: 37$ 
Agradecimentos

A realização desta dissertação só foi possível com a colaboração das pessoas que acompanharam a sua elaboração.

À minha orientadora, Profa. Maria Angela Faggin Pereira Leite, agradeço pela importância de suas críticas, às vezes implacáveis, mas sempre instigantes e permeadas de humor e afeto, levando-me a repensar, questionar e aprofundar as idéias deste trabalho.

Aos professores Ari V. Fernandes e Francisco de Oliveira, que integraram a banca de qualificação, contribuindo com experiência e sensibilidade ao esclarecer as deficiências e avanços do trabalho, e pelo apoio generoso durante o processo de pesquisa.

À Profa. Catharina Cordeiro Lima e à Profa. Vera Pallamin, pelos importantes subsídios ao longo de meu trabalho e pela amizade sempre presente.

A Regina Cardarelli, que me brindou generosamente com o relato de sua experiência no IPC-FAU-SJ C, suas dúvidas e certezas, que motivaram e permitiram evoluir na pesquisa. Pelas sugestões, pelos desenhos e, sobretudo, pela valiosa amizade.

A Ana Claudia Barone, Caio Boucinhas e Raul Pereira, pelas contribuições generosas, discussões esclarecedoras, incentivo e valiosa amizade. 
Aos arquitetos Paulo Bastos, Miguel Pereira, Guto Lacaz, Nabil Cury, Renato Araujo, Renato Daud, I ves de Freitas, Yara Vicentini, José Manoel Esteves de Castro, Carlos H. Heck, Silvia Vitale e o amigo e colega Luiz G. Ackel, que através das entrevistas brindadas abriram seu baú de lembranças, imprescindíveis para a realização desta tese. À Profa. Nídia Pontushka, pelas importantes reflexões, pelo apoio e amizade.

À equipe do LAPECH-FEUSP, que possibilitaram o conhecimento das problemáticas da educação e a prática do trabalho em equipe interdisciplinar.

A Emilene Miossi, pela digitação, editoração e diagramação deste, e o apoio e carinho sempre presentes.

A Mirtes Leal Boucinhas, pela paciente revisão esclarecedora e pela amizade.

A Silvia Alicia Martinez e Nora Lamfri, que sem me conhecer me brindaram generosamente com seus conhecimentos sobre o tema e os documentos valiosos enviados.

Ao Prof. Carlos Eduardo Zahn, pelas sugestões e críticas durante 0 processo de trabalho.

Aos funcionários da secretaria da Pós-FAUUSP: Cilda, Cristina, Dina, Isa, Ivani, Maria I nês e Sara; às bibliotecárias: Estelita, Filomena e Maria José, pelo apoio e amabilidade durante todo o período desta pesquisa.

Aos amigos participantes do Ateliê Total de Arquitetura: Benjamim Elkin, Elsa Chanaguirre, Carlos Pronsato, Sônia Filoñuk, Victor Barrionuevo e Maria Violeta Uehara, que me ajudaram na recuperação da memória dessa experiência.

À amiga Denise Pessoa, pela tradução do resumo, as reflexões pertinentes e 0 incentivo. 
Aos amigos Fanny Galander, Maria de Lourdes Nogueira, Suzel Maciel e Edgard Couto, que me estimularam tecendo comentários e sugerindo aprimoramentos e a Maria Inês Ghiraldelli Fiaschi pelo desenho da FAUUSP à rua Maranhão.

Ao Marco Antônio Ruivo, pelo apoio e a paciência permeada de humor. Às minhas filhas, cujo afeto foi decisivo nos momentos de maior ansiedade: a Andrea, pelo apoio e carinho sempre presentes; a Carla, pela paciência carinhosa, pelo esforço da digitação e as discussões esclarecedoras sobre arte; a Laura, pelas críticas construtivas e severas, porém permeadas de afeto e sempre importantes, e as reflexões sobre arte e educação, suas dúvidas e certezas que me ajudaram a evoluir na pesquisa. 
Sumário

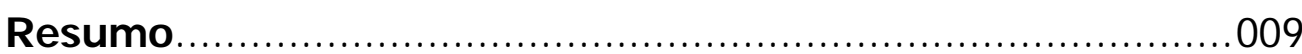

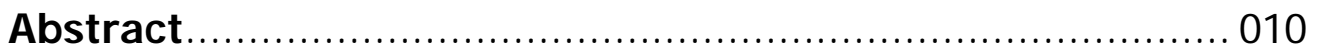

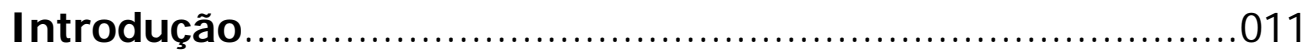

Parte I

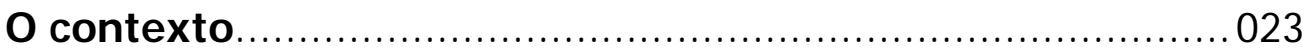

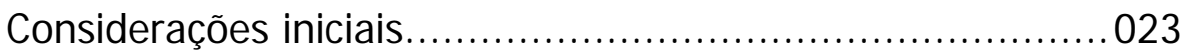

\section{Capítulo I}

Subdesenvolvimento e capitalismo............................ 028

Desenvolvimentismo............................................. 029

A comissão econômica para America Latina(CEPAL).............030

A OEA e as políticas de Ensino Superior............................. 031

Os anos 1950 e as independências das FAUs.................... 035

\section{Capítulo II}

Acumulação e paisagem nas periferias urbanas........ 037

Passagem de ciclos.................................................. 038

Exército de reserva, mutirões e a paisagem das favelas....... 040

0 inchaço do terciário................................................... 041

\section{Parte II}

O ensino de Arquitetura e Urbanismo................................ 045

Considerações I niciais...................................................... 045

\section{Capítulo I}

As políticas publicas de Ensino Superior.....................046

O ensino superior no Brasil nos anos1960 a 1980............... 048

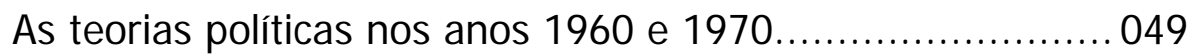

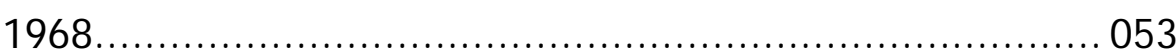

Novas questões para o debate no ensino de arquitetura...... 059

O papel da Reforma de 1968........................................ 061

A expansão do Ensino Superior Privado............................. 062

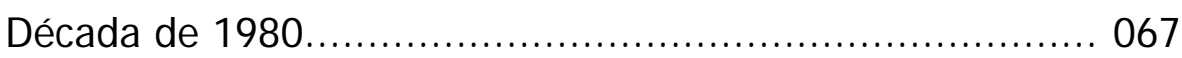

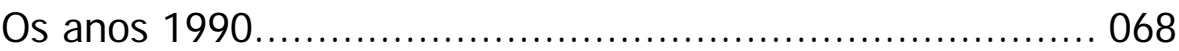




\section{Capítulo I I}

Algumas experiências de Ensino de Arquitetura e Urbanismo

São Paulo -Brasília - Córdoba.................................... 072

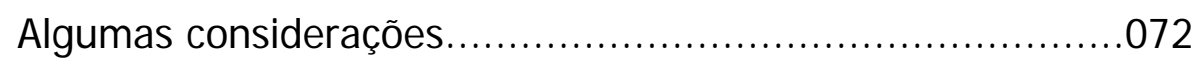

Reorganização do capital no nível do ensino superior..........073

Dois paradigmas para a universidade.............................. 075

Algumas experiências de ensino de Arquitetura e Urbanismo:

São Paulo/ Brasília/ Córdoba............................................ 076

FAU-UNC …............................................................... 078

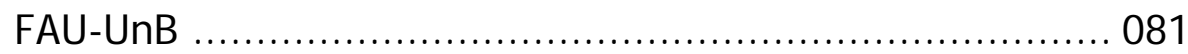

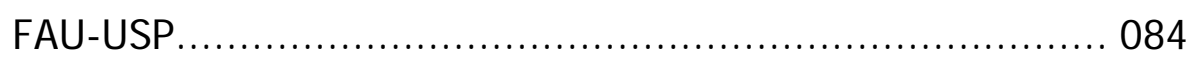

\section{Capítulo III}

Ditaduras e ensino de Arquitetura e Urbanismo

São Paulo - Brasília - Córdoba....................................... 096

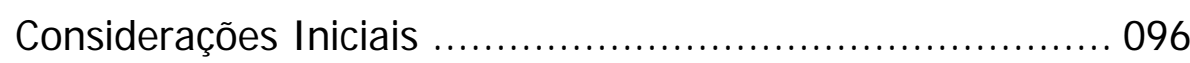

Fórum de 1968 na FAU-USP - 1969 e o Al 5....................... 098

Reabertura da FAU-UnB em 1968 ................................... 103

As origens do Taller Total em Córdoba - 1968-1970 ............ 115

A memória e a transmissão .........................................116

Algumas palabras sobre a UNC ….................................... 117

“Universidade e vai e vens políticos cruzam os anos 60"..... 118

\section{Parte I I I}

\section{Para Quem e Com Quem: O ensino critico e participativo de}

Arquitetura e Urbanismo.

Considerações I niciais..................................................... 135

\section{Capítulo I}

Bauhaus, Hannes Meyer e Ernest May....................... 136

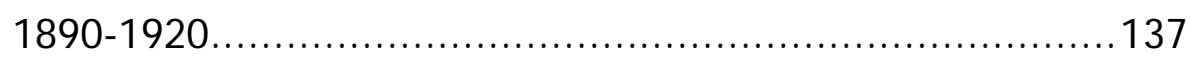

A República de Weimar............................................ 139

Período da inflação ............................................................140

As experiências de Ernest May e Hannes Meyer durante 0 período da inflação.......................................................149

Período da estabilização temporal (1923 a1928).................152

Ernest May e equipe em Frankfurt.....................................155

A Bauhaus no segundo período da prosperidade econômica 159 Hannes Meyer e a Bauhaus (1928-1930)........................... 161 


\section{Capítulo II}

O Taller Total................................................................ 169

A inter-relação contexto - Taller Total.................................169

Duas propostas de ensino.............................................. 175

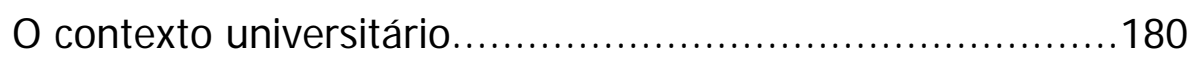

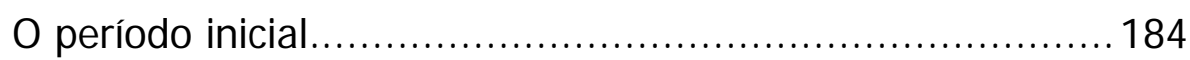

O Taller Total - considerações gerais................................. 185

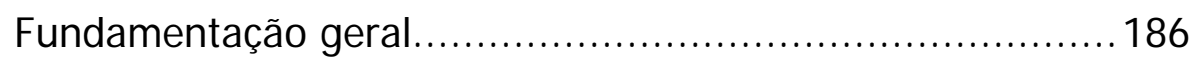

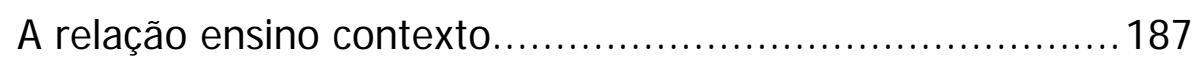

A fundamentação pedagógica.......................................... 190

Objetivo pedagógico do Taller Total.................................. 191

Forma organizativa da primeira etapa do Taller Total...........192

1970 - currículo inicial.......................................................... 192

Pontos principais da avaliação do ano letivo de 1970.......... 197

As transformações desejáveis e necessárias....................... 198

Plano de Estudos para 1971............................................200

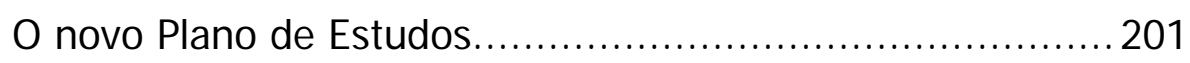

Esquema funcional do Taller Total....................................204

Funções das áreas e sub-áreas......................................... 205

I déias paradigmáticas do Taller Total............................... 207

A discussão sobre a formação do arquiteto........................ 209

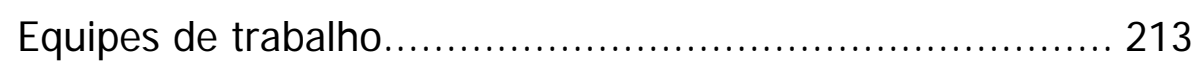

Comissões de trabalho................................................ 213

A função das coordenadorias........................................ 214

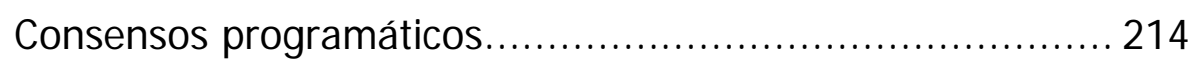

A Equipe de Pedagogia................................................ 215

Temas desenvolvidos................................................ 217

Carreira docente e concursos........................................... 219

\section{Capítulo III}

FAU-SJ C: O I PC-I nstituto de Projeto e Comunicação 225

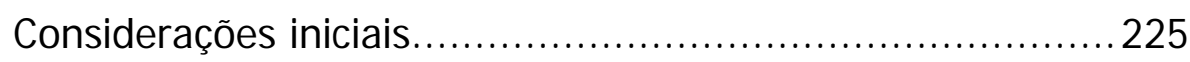

As novas FAUs privadas no estado de São Paulo................ 229

Implantação da FAU-SJ C e sua relação com a cidade de São J osé

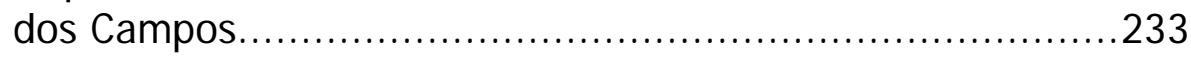

Conversações iniciais para a abertura da FAU-SJ C............... 236

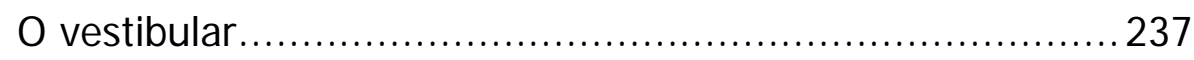

Proposta inicial: o IPC................................................ 237

$1^{\text {a }}$ crise: o curso seriado $\left(2^{\circ}\right.$ semestre de 1970$) \ldots \ldots \ldots \ldots \ldots . . . .243$

A resistência ao curso seriado: a volta do IPC.................... 244 


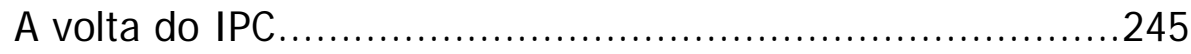

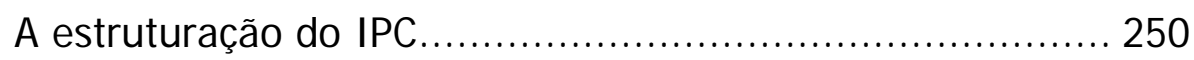

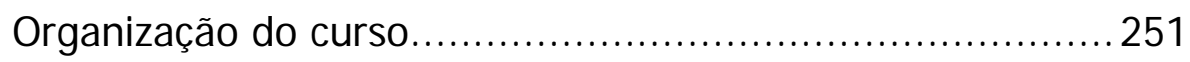

A relação com a comunidade.......................................... 252

O debate sobre a formação do arquiteto na FAU-SJ C........... 255

Redução da proposta inicial do IPC..................................256

Efetivação do Ateliê Integrado........................................... 257

\section{Capítulo IV}

Das críticas ao Ateliê às Unidades I nterdepartamentais

de Ensino e Pesquisa na FAU-SJ C .............................263

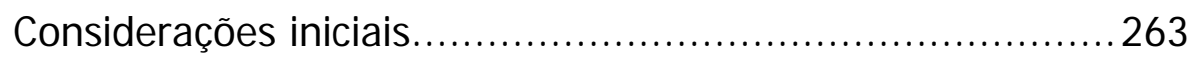

As críticas ao Ateliê na FAU-SJ C.......................................... 266

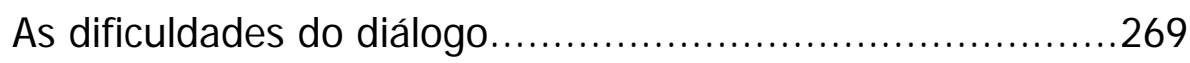

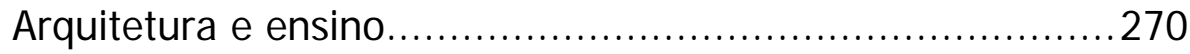

Arquitetura, urbanismo e contexto................................... 272

Paulo Freire, Arquitetura e ensino participativo.................. 279

O novo perfil do arquiteto a partir dos anos 1970:

desmistificando a profissão........................................... 281

A estrutura organizacional............................................ 287

As unidades interdepartamentais de Ensino e Pesquisa e os

Órgãos das Escolas de Arquitetura.................................... 297

Procurando a institucionalização......................................297

Considerações finais............................................................. 303

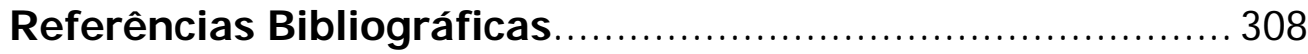

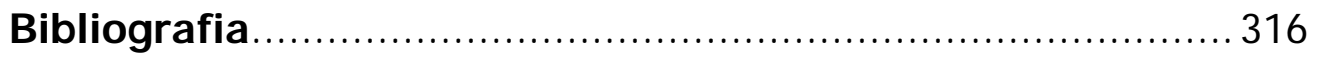


Resumo

O tema deste doutorado refere-se à formação do arquiteto, centrado no debate sobre $o$ ensino de arquitetura e urbanismo que permeou as décadas de 1960, 1970 e 1980, tendo como objeto de trabalho a experiência de ensino na FAU-SJ C, Faculdade de Arquitetura de São J osé dos Campos, inicialmente conhecida como IPC, Instituto de Projeto e Comunicação, nos anos 1970 a 1976.

As experiências de ensino de Arquitetura e Urbanismo, nos anos 1970, consideradas pioneiras e analisadas neste trabalho - a da FAU-SJ C como objeto de trabalho, as das FAUs USP e UnB, como referências diretas no Brasil, e o Taller Tota/ na FAU-UNC Argentina, como referência indireta - são parte do debate latino-americano sobre 0 ensino de arquitetura e urbanismo iniciado nos anos próximos a 1960, que re-valorizava o pensamento da Bauhaus.

Parte-se da idéia de que o contexto econômico, social, cultural do país indica um determinado tipo de necessidade de formação profissional. A crença nessa afirmação traz à discussão a organização dos currículos e o projeto pedagógico dos cursos de arquitetura e urbanismo que melhor atendam a essa solicitação. 


\section{Abstract}

The theme of this thesis refers to the architect's education and is centered in the debate of the teaching of architecture and urbanism that occurred during the decades of 1960, 1970 and 1980. It presents, as study object, the teaching experience of the FAU-SJC, Faculdade de Arquitetura de São J osé dos Campos, known in the beginning, from 1970 to 1976, as IPC, Instituto de Projeto e Comunicação.

The teaching experiences in Architecture and Urbanism in the 1970s, which are considered pioneers, are analyzed in this work. They are: FAU-SJ C as a central focus, FAU-USP (Faculdade de Arquitetura e Urbanismo - Universidade de São Paulo) and UnB (Universidade de Brasília), as direct references in Brazil, and Taller Tota/ in FAU-UNC (Facultad de Arquitectura y Urbanismo de la Universidad Nacional de Córdoba) in Argentina as indirect references. These schools took part of the Latin American debate about the teaching of architecture and urbanism which started in the 1960s and revalued the Bauhaus thinking.

It is supposed that the economical, social and cultural context of the country points to a certain kind of professional education. The belief in this affirmation brings to discussion the curriculum organization and the pedagogical project in the schools of architecture and urbanism that better accomplished this solicitation. 


\section{INTRODUÇÃO}

\section{As inquietações iniciais}

Antes de iniciar as reflexões neste texto, gostaria de acrescentar algumas considerações que podem esclarecer a leitura do que virá posteriormente.

Algumas tendências de arquitetura e urbanismo argumentam que a arquitetura é indissoluvelmente ligada à paisagem, entendida como processo e produto da ação dos homens; outras consideram que a arquitetura é só o projeto do edifício isolado.

Colocando-me desde o primeiro ponto de vista já durante a pesquisa de mestrado, na busca da gênese do processo participativo, ao realizar entrevistas com arquitetos paisagistas foi possível constatar que as idéias participativas tinham origem em sua formação nas faculdades de arquitetura, através de professores e estudantes ligados às lutas populares de resistência à ditadura, como também às lutas por moradia e educação popular, que evoluíram, no processo, para preocupações ligadas à paisagem e ao ambiente.

Também durante o desenvolvimento desse mestrado tomei contato com as idéias de Sérgio Ferro, Mayumi Souza Lima, Flávio Império, Rodrigo Lefèvre, percebendo que, de maneira diferente em cada um deles, havia pontos de contato com as idéias debatidas nos anos 1960 e 1970 na FAU-UNC (Córdoba, Argentina), em especial com o debate incluído na experiência do Taller Total de Arquitectura, da qual participei. Vários professores da FAU-USP, entre eles Sylvio Sawaia e Miguel Pereira, afirmaram, seja em conversas informais, seja em entrevistas concedidas à autora, que a experiência do Taller Total fora 
discutida no âmbito da FAU-USP e na FAU-UnB, sendo referência para esta última após sua reabertura nos anos 1970.

Ao tomar conhecimento da experiência de ensino de arquitetura que se desenvolveu nos anos 1970-1976 na FAU-SJ C, constatei que ela se deu no mesmo período da realização do Taller Total, em Córdoba, Argentina. A participação nessa experiência, considerada pioneira por diversos autores, foi no início uma forte motivação para a elaboração deste trabalho, que foi mostrando coincidências e diferenças entre as duas práticas de ensino de arquitetura, desenvolvidas no mesmo período, em países diferentes da América Latina, ambas em momentos conturbados da história desses países, apesar de suas especificidades. A bagagem adquirida nesses anos foi revertida e enriquecida em várias atividades que em outro momento histórico vim a desenvolver em São Paulo, Brasil. Atividades que, considero, têm filiação similar. Entre elas, a participação no Projeto 'Uma Fruta no Quintal', em Diadema (1996) sob a coordenação geral do arquiteto Raul Pereira e a coordenação, entre outros, do arquiteto Caio Boucinhas -, que foi também objeto de reflexão na pesquisa de mestrado.

Foram os professores das escolas de primeiro e segundo grau de Diadema que, observando coincidências de idéias, me indicaram 0 Laboratório de Pesquisas e Ensino em Ciências Humanas, FE-USP, coordenado pela professora Nidia Nacib Pontuschka. É uma equipe interdisciplinar que realiza, entre outros trabalhos, Estudos do Meio, dando apoio a professores da rede estadual e municipal.

Entre eles, destaco o Estudo do Meio na Aldeia de Carapicuíba. Essa atividade começou com um acordo entre FAU-USP (com um grupo de alunos de uma disciplina de pós-graduação ministrada pelo professor doutor Sylvio Sawaya), a FE-USP (através do Lapech) e a EEPG Esmeralda Becket.

Nessa oportunidade, desenvolvi, junto com uma equipe, um trabalho que, acadêmico no início, estendeu-se depois além desse limite - 
englobando um projeto de revitalização urbana na Aldeia de Carapicuíba, São Paulo. A equipe contou com a consultoria do arquiteto Caio Boucinhas, reponsável pelo processo que visava a elaboração de um parque, conforme exigência da Prefeitura de Carapicuíba. 0 Estudo do Meio, que teve coordenação da professora Nidia Nacib Pontuschka, foi realizado na Escola Esmeralda Becker. Entre os objetivos a serem atingidos, um dos mais relevantes era a inter-relação e o debate, entre os professores das diversas disciplinas, para elaborar um processo interdisciplinar de construção de conhecimento. Outro objetivo era conhecer o lugar, o que ele poderia nos revelar, seus moradores, seus sonhos, suas ações no quotidiano.

A experiência junto à equipe do Lapech e com arquitetos preocupados com a realização de projetos de arquitetura e urbanismo de forma participativa veio ao encontro de aspirações despertadas já no Taller Total: o desenvolvimento da formação docente para o ensino de arquitetura, a construção de conhecimentos de maneira interdisciplinar e inseridos na realidade - e o aprofundameto nas teorias de Paulo Freire e Gramsci, questões que foram também objeto de reflexão no desenvolvimento do mestrado. Estes últimos, entre outros, contribuíram para despertar o interesse no tema desenvolvido neste doutorado, com o título Para quem e com quem: ensino de arquitetura e urbanismo.

No inicio as idéias estavam muito ligadas ao mestrado, publicado em 2005 com o título Arquitetura e Paisagem, Projeto Participativo e Criação Coletiva, e à minha experiência de ensino de arquitetura no Taller Total, na Argentina.

Aos poucos, a linha de pesquisa foi-se moldando de forma mais abrangente e aprofundada, por focalizar melhor o tema em questão. Esse aprofundamento ocorreu sobretudo no recorte do período escolhido e na definição de quais experiências seriam abordadas como objeto de trabalho, como referência e como comparação. A partir da 
pesquisa inicial no interior dessas experiências de ensino de arquitetura, foi possível o aprofundamento no referencial teórico que permitiu uma percepção mais ampla do tema pesquisado, delimitando, definindo e esclarecendo melhor os eixos a serem estudados.

\section{O trabalho}

O tema deste doutorado refere-se à formação do arquiteto, centrado no debate sobre ensino de arquitetura e urbanismo que permeou as décadas de 1960, 1970 e 1980, tendo como objeto de trabalho a análise da experiência de ensino na FAU-SJ C, Faculdade de Arquitetura de São J osé dos Campos, inicialmente conhecida como IPC, Instituto de Projeto e Comunicação, nos anos 1970 a 1976.

A FAU-SJ C é parte de um conjunto de experiências de ensino de arquitetura e urbanismo, com teor crítico e intenção transformadora, que discutia o papel do arquiteto na sociedade e na educação universitária, no período próximo aos anos 1960 a 1986.

Essas experiências inscreveram-se nas políticas públicas de ensino superior no Brasil, no seu contexto histórico vinculado ao latinoamericano e suas principais referências mundiais, já que existia uma profunda e complexa relação, no marco do processo de internacionalização do capital, que provocou reflexos no plano da arquitetura, do urbanismo e seu ensino.

A relevância da experiência de ensino, objeto deste doutorado, foi expressada na abertura do IV Seminário do Curso de Arquitetura da Faculdade de Belas Artes, em 1983, na qual Miguel Pereira resgatou a FAU-SJ C como uma das experiências mais importantes no ensino de arquitetura no Brasil, como também o Taller Tota/ de Arquitetura na FAU-UNC, conhecida em toda América Latina com esse nome. Segundo Miguel Pereira, essas idéias vieram para o Brasil e conseguiu-se colocar em pauta algumas experiências, entre elas a da FAU-UnB, que tentou desenvolver a idéia do ateliê total depois da reabertura de 1968. 
Nos anos próximos a 1970, o debate sobre arquitetura e urbanismo e seu ensino, implícito no debate político na América Latina, no que se incluem as diferentes visões sobre subdesenvolvimento, assume uma dimensão particularmente acirrada na capital e em outras cidades do estado de São Paulo. Foi talvez a FAU de São J osé dos Campos o caso em que essas divergências foram mais aprofundadas e explicitadas. As oposições da época, participação e alienação e opressão e liberdade sinalizavam polarizações do debate inseridas em diferentes visões da sociedade, conservadoras ou transformadoras.

Essas experiências de ensino de arquitetura e urbanismo estavam imersas no acelerado processo de privatização do ensino, no contexto da expansão do capital, que promovia mudanças políticas e sociais, sobretudo por meio de reformas, que se expressavam no ensino superior.

Nesse contexto, não foram elaboradas, mesmo com o fim do regime militar, propostas inovadoras e consistentes de reformulação do ensino de arquitetura e urbanismo. Isso traz à tona a importância de se retomar esse debate.

Parte-se da idéia de que o contexto econômico, social e cultural do país indica um determinado tipo de necessidade de formação profissional. A crença nessa afirmação traz à discussão a organização dos currículos e o projeto pedagógico dos cursos de arquitetura e urbanismo que melhor atendam a essa solicitação.

As experiências de ensino de arquitetura e urbanismo, nos anos 1970, consideradas pioneiras e analisadas neste trabalho - a da FAU-SJ C como objeto de trabalho, as das FAUs USP e UnB como referências diretas no Brasil e o Taller Total, na FAU-UNC, Argentina, como referência indireta - são parte do debate latino-americano sobre ensino de arquitetura e urbanismo iniciado nos anos próximos a 1960, que revalorizava o pensamento da Bauhaus. 
Este trabalho tem, como objetivo geral, contribuir com o resgate do debate sobre ensino de arquitetura e urbanismo realizado nos anos 1970, visando encontrar formas desse ensino que respondam criativa e inovadoramente e com intenção transformadora às contradições incluídas na dialética arquitetura-sociedade.

Faz parte ainda dos objetivos do trabalho trazer contribuições para a arquitetura e urbanismo e seu ensino, discutindo aspectos da criatividade coletiva-individual e interdisciplinar que contemplem a participação como parte integrante do processo projetual. E também colaborar com a construção de uma relação dialética entre os movimentos populares de inserção social e o processo de ensino de arquitetura e urbanismo, visando discutir suas diretrizes.

\section{Metodologia}

Nos recortes históricos realizados inclui-se a relação entre o ensino, a comunidade e seu ambiente, vista como processo dinâmico, que exigiu o estabelecimento de categorias de análise relacionando o objeto de pesquisa com o contexto.

A metodologia privilegiou a relação entre o pesquisador e o objeto de pesquisa, utilizando como estratégia de investigação análise bibliográfica, entrevistas, fotografias, desenhos etc.

\section{Estrutura do trabalho}

Os capítulos que integram este doutorado foram desenvolvidos e organizados de forma a permitir que a busca de um suporte teórico proporcione maior enriquecimento e aprofundamento da reflexão sobre as experiências de ensino de arquitetura e urbanismo citadas, visando criar um sistema dialético de conhecimentos práticos e teóricos. Está, portanto, desde o inicio, delineada a busca de reflexão teórica que irá 
permear todo o trabalho, que, para melhor compreensão, apresenta-se dividido em três partes:

Parte I - O contexto

Parte II - O ensino de arquitetura e urbanismo

Parte III - Para quem e com quem: o ensino crítico e participativo de arquitetura e urbanismo

Na parte I - O contexto, que contém os capítulos I e II - realizei uma reflexão sobre a relação ensino de arquitetura e sociedade no período que vai dos anos 1960 até meados da década de 1980.

Esses anos foram pródigos, na área de arquitetura e urbanismo, em experiências de ensino com teor crítico e intenção transformadora e em discussões sobre o papel do arquiteto na sociedade. Tais experiências, objeto deste trabalho - em particular o processo vivenciado na Faculdade de Arquitetura e Urbanismo de São J osé dos Campos, SP (FAU-SJC) -, foram identificadas por meio de depoimentos e análises bibliográficas.

No capítulo I - Subdesenvolvimento e capitalismo - considerei a necessidade, para entender o contexto geral, de remeter ao estudo de Francisco de Oliveira, em Crítica à razão dualista e 'O ornitorrinco', por conter uma visão esclarecedora que pode se estender a outros países latino-americanos apesar de suas especificidades.

As reflexões desse autor, que remetem à idéia de que 0 subdesenvolvimento está incluído na formação capitalista, e sua crítica à teoria desenvolvimentista, contribuíram para a compreensão das relações entre contexto, arquitetura e ensino, e permitiram explicar os debates acirrados, presentes nas experiências analisadas.

Analisei brevemente o período da pós-Segunda Guerra Mundial, para o que contribuíram também as idéias de Nicolau Sevcenko. A política da Comissão Econômica para América Latina, as relações entre a OEA e as 
políticas públicas de Ensino Superior foram temas desenvolvidos com 0 apoio de, entre outros autores, Alexander da Silva Machado.

Nesse contexto, foi possível entender como nos anos 1950 as FAUs tornaram-se independentes, seja das faculdades de engenharia, seja das escolas de belas artes (constatando-se que esse processo ocorreu também, nesses anos, em outros países da América Latina e do mundo).

Ainda na parte I, capítulo II - Acumulação e paisagem nas periferias urbanas - , tratei das relações entre o processo de industrialização no Brasil, a formação do exército de reserva e a paisagem nas periferias das cidades e suas características, que inclui 0 tema da habitação para as amplas massas, problemas que no Brasil são revelados também nas formas não resolvidas de acesso à terra. As formulações de Francisco de Oliveira deram suporte teórico à analise realizada. Esses temas foram, de varias maneiras, centro de debates e fortes preocupações nas experiências de arquitetura e urbanismo apresentadas.

Na parte II - O ensino de arquitetura - considerei necessário, para entender essas experiências, fazer uma análise das políticas públicas de ensino superior no Brasil em seu contexto histórico, vinculado ao latinoamericano e mundial, já que foi possível perceber, mediante a pesquisa bibliográfica, a existência desse vínculo, no marco do processo de mundialização do capital.

No capítulo I - As políticas públicas de ensino superior selecionei como referência a pesquisa realizada por João dos Reis Silva Jr. e Valdemar Sguissardi por abranger os aspectos mais densos e centrais do contraditório processo de reforma e redisposição do sistema de educação superior no Brasil, tanto público quanto privado. A analise do movimento de privatização desse ensino durante as décadas de 
1960-80, contribui para entender o contexto em que se desenvolveu a FAU-SJ C, objeto de trabalho deste doutorado.

O ano de 1968 mereceu destaque, com base nas contribuições teóricas de Alvaro Tarazona, Eric Hobsbawm e Jorge Volpi, que me ajudaram a entender essa emblemática referência das novas questões para 0 debate do ensino de arquitetura e urbanismo no contexto brasileiro, latino-americano e mundial.

Na parte II, capítulo II - Algumas experiências de ensino de arquitetura e urbanismo: São Paulo - Brasília - Córdoba elaborei um breve histórico de momentos relevantes no ensino de arquitetura e urbanismo com caráter democrático e intenção transformadora, fazendo um recorte em São Paulo (cidade e estado), Brasília e Córdoba, Argentina, entre os anos próximos a 1960 e 1980. Considerei também necessário, para entender essas experiências, completar a análise das políticas públicas de ensino superior no Brasil e teci algumas considerações sobre a atualidade, a partir dos anos 1990, detendo-me na reorganização do capital no campo do ensino superior. A análise permitiu perceber que as experiências de ensino de arquitetura selecionadas estão incluídas na política de privatização do ensino que no Brasil fora consolidada pela ditadura militar de 1964 e que vem se manifestando até hoje. Esse processo contém o embate entre dois paradigmas: por um lado, o projeto de construção de uma universidade democrática, crítica de si mesma e da sociedade e, por outro lado, a idéia da universidade-grande empresa, onde o saber é considerado mercadoria, embate que tem reflexos nos cursos de arquitetura analisados.

Enfoquei nesse capítulo os anos próximos a 1960, palco de debates no ensino de arquitetura em toda a América Latina, a partir das experiências da FAU-UNC (Argentina), FAU-USP e FAU-UnB, estas últimas referências diretas para a formação da FAU-SJ C. Fazem parte desse período, e foram também analisadas, a reforma na FAU-USP em 
1962 e a criação da ICA-FAU-UnB, nos seus respectivos contextos, vistas como parte do debate latino-americano sobre o ensino de arquitetura e urbanismo.

Ainda na parte II, capítulo III - Ditaduras e ensino de arquitetura e urbanismo: São Paulo - Brasília - Córdoba -, tratei dos processos de ensino de arquitetura e urbanismo desenvolvidos na FAUUSP, em São Paulo, na FAU-UnB, em Brasília, e na FAU-UNC, em Córdoba, Argentina, no período das ditaduras militares, a partir de 1964 no Brasil e de 1966 na Argentina.

Destacou-se o Fórum de 1968 na FAU-USP, a reabertura da FAU-UNB, fruto da resistência à ditadura militar, e o Al 5 e as origens do Taller Tota/ da FAU-UNC, processo relacionado à resistência à ditadura militar argentina, tendo como marco a insurreição popular conhecida como o Cordobazo.

Por fim, da parte III - Para quem e com quem: o ensino crítico e participativo de arquitetura e urbanismo - constam quatro capítulos.

O capítulo I - Bauhaus, Hannes Meyer e Ernest May - aprofundouse em aspectos da análise realizada durante o mestrado sobre a experiência da Bauhaus. Partindo dessa análise, estabeleci relações entre a experiência de Ernest May e equipe em Frankfurt e a Bauhaus, especialmente no período de Hannes Meyer: uma como expressão arquitetônica e urbanística, outra como expressão de ensino daquele momento histórico na República de Weimar.

Elaborei previamente uma base teórica para compreender mais profundamente essas questões, para o que os primeiros capítulos de Pela mão de Alice - o social e o político na pós-modernidade, de Boaventura de Sousa Santos, possibilitaram discutir a diversidade de análises dentro do marxismo, fazendo um recorte histórico desde fins do século XIX até as primeiras décadas do século XX. Também 
considerei interessante registrar a reflexão realizada por Hannes Meyer sobre esse período. A escola Bauhaus no campo da educação contém experiências de interdisciplinaridade, nos ateliês integrados, interníveis e atitudes transdisciplinares de professores e alunos, assim como a prática unida à teoria. Porém, as argumentações de Meyer, Tafuri e Rodrigues, entre outros, demonstram que tanto a escola Bauhaus como a corrente arquitetônica que representa não conseguiram resolver a questão estrutural da sociedade: quem produz e para quem se produz. No capítulo II - O Taller Total - remeto-me à proposta de ensino da FAU-UNC que vigorou entre os anos 1970 e 1976. Seu nome pode ser traduzido por Ateliê Total, porém conservei o nome original, por ser uma referência assim conhecida em toda a América Latina. Nessa experiência o contexto político-social exerceu um forte impacto, na sua gestação, na sua implementação, em seus re-desenhos e no posterior fechamento. O capítulo foi desenvolvido com base nas contribuições de Benjamin Elkin, Silvia Alicia Martinez, Nora Lamfri e no documento conhecido como Livro Mostarda - primeira publicação que ordenou todos os aspectos do Taller Total - , que me ajudaram na recuperação das minhas memórias e no suporte teórico para a análise dessa experiência. Ela questionou a caducidade do modelo vigente e destacou a importância de se inserir na realidade e entendê-la. Consistiu na incorporação de todos os professores e estudantes da faculdade na construção de uma proposta interdisciplinar com um currículo inovador, numa gestão democrática e participativa.

Os capítulos III e IV da parte III tratam da FAU-SJ C e foram desenvolvidos principalmente com base na análise aprofundada de documentos e depoimentos coletados durante a pesquisa.

As idéias de Mayumi Souza Lima e Edgard Graeff, entre outros, assim como o documento apresentado ao IX Congresso Brasileiro de Arquitetos - de autoria de professores e alunos da FAU-SJ C, entre eles Ari V. Fernandes, Monica P. Nador, Lineu C. Maffezoli, Yara Vicentini 
Fernandes, Ives de Freitas - me ajudaram a analisar e discutir essa experiência, verdadeiro "laboratório de ensino", no qual estiveram presentes vários modelos expressando a relação de forças de cada momento, na maioria dos quais foi possível um denominador comum: 0 de desenvolver um ensino crítico inserido na realidade e uma gestão democrática e participativa.

\section{No capítulo III - FAU-SJ C: O I PC - Instituto de Projeto e}

Comunicação - apresentei o processo inicial dessa faculdade, seus objetivos e sua organização no contexto da privatização do ensino superior no estado de São Paulo. O processo foi marcado desde o início pelos embates com a instituição mantenedora, que, a exemplo de suas congêneres, pouco sabia sobre ensino de arquitetura e tentou adaptar esse curso aos modelos convencionais de outros mais tradicionais.

No capítulo IV - Das críticas ao ateliê às unidades interdepartamentais de ensino e pesquisa na FAU-SJ C - analisei, a partir das criticas ao ateliê, o processo que levou à implantação dessas Unidades, verificando que o debate sobre ensino de arquitetura e urbanismo está implícito na luta entre dois paradigmas: o da Universidade como crítica de si mesma e da sociedade e o da Universidade grande-empresa, que carrega consigo a idéia do sabermercadoria. 
Parte I

\section{O CONTEXTO}

\section{Considerações iniciais}

Os anos que vão de 1962 a 1986 foram pródigos, na área de arquitetura e urbanismo, em experiências de ensino com teor crítico e intenção transformadora, em discussões sobre o papel do arquiteto na sociedade e na educação universitária. Tais experiências, objeto deste trabalho - em particular o processo vivenciado na Faculdade de Arquitetura e Urbanismo de São J osé dos Campos, SP (FAU-SJC) - , foram identificadas por meio de depoimentos e análises bibliográficas ${ }^{1}$. Primeiramente se verificou quando e onde aconteceram, se no interior de instituições públicas ou privadas e quais os professores e coordenadores que delas participaram (ver Quadro 1, na página seguinte).

Essa pesquisa conduziu a um grupo de professores, na sua maioria arquitetos, entre eles Sérgio Ferro, Flávio Império, Rodrigo Lefèvre, Paulo Bastos, Edgard Graeff, Miguel Pereira, Ari Fernandes, Ermínia Maricato, Mayumi W. de Souza Lima, Sérgio Souza Lima, e outros, como o sociólogo Francisco de Oliveira (que participou da FAU-Santos). Eles transitaram por diversas experiências, em diferentes momentos ou simultaneamente, e tinham em comum uma visão de mundo, do ensino e da arquitetura, além de referências teóricas elaboradas em conjunto, já que muitos deles se reuniam para estudar e debater.

\footnotetext{
${ }^{1}$ Informações fornecidas por Carlos H. Heck, Carlos F. Martins, Raul Pereira, Ermínia Maricato, Paulo Bastos, entre outros, em São Paulo, em 2006. Bibliografia: Arantes, 2002; Koury, 2003.
} 


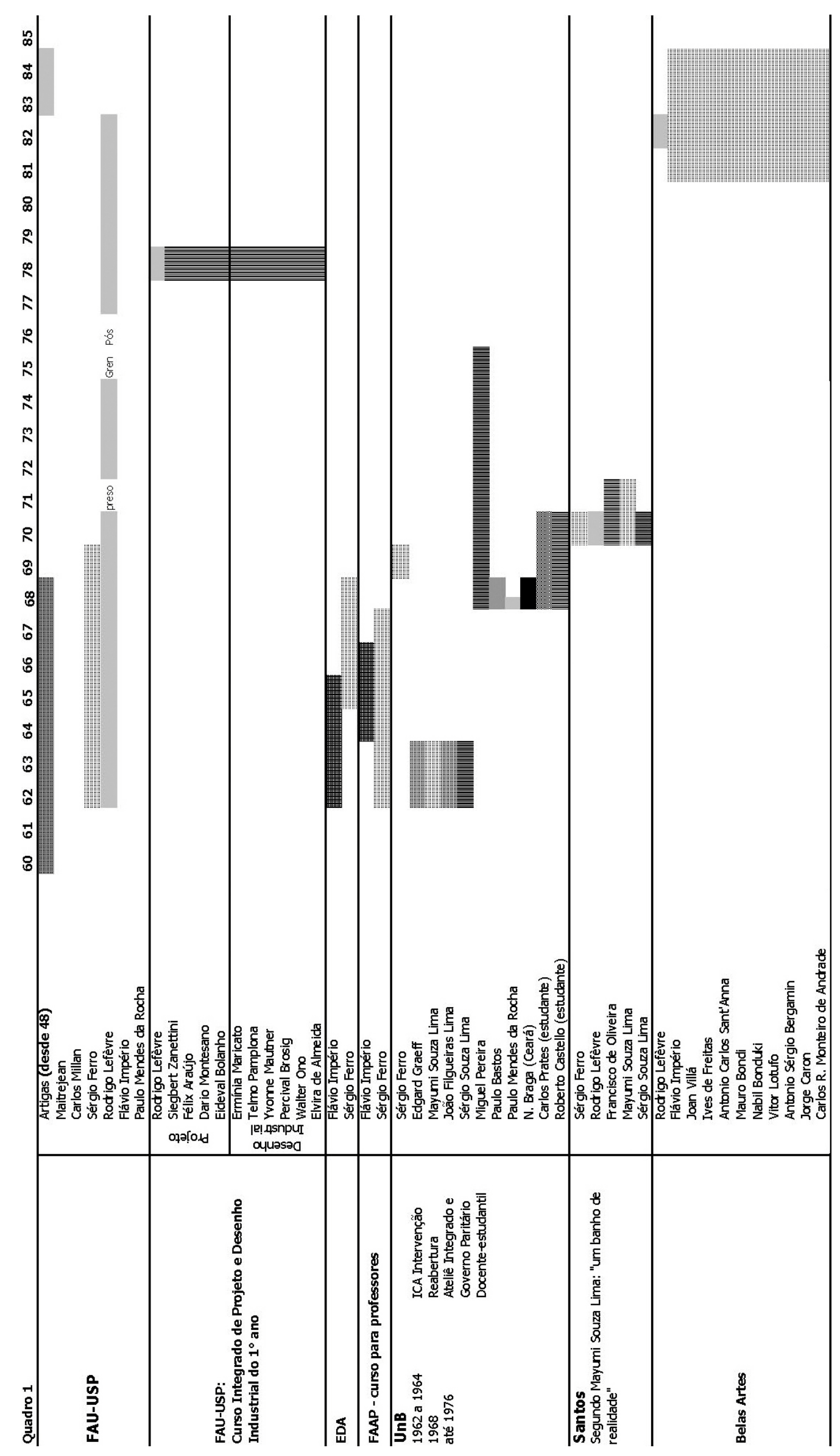



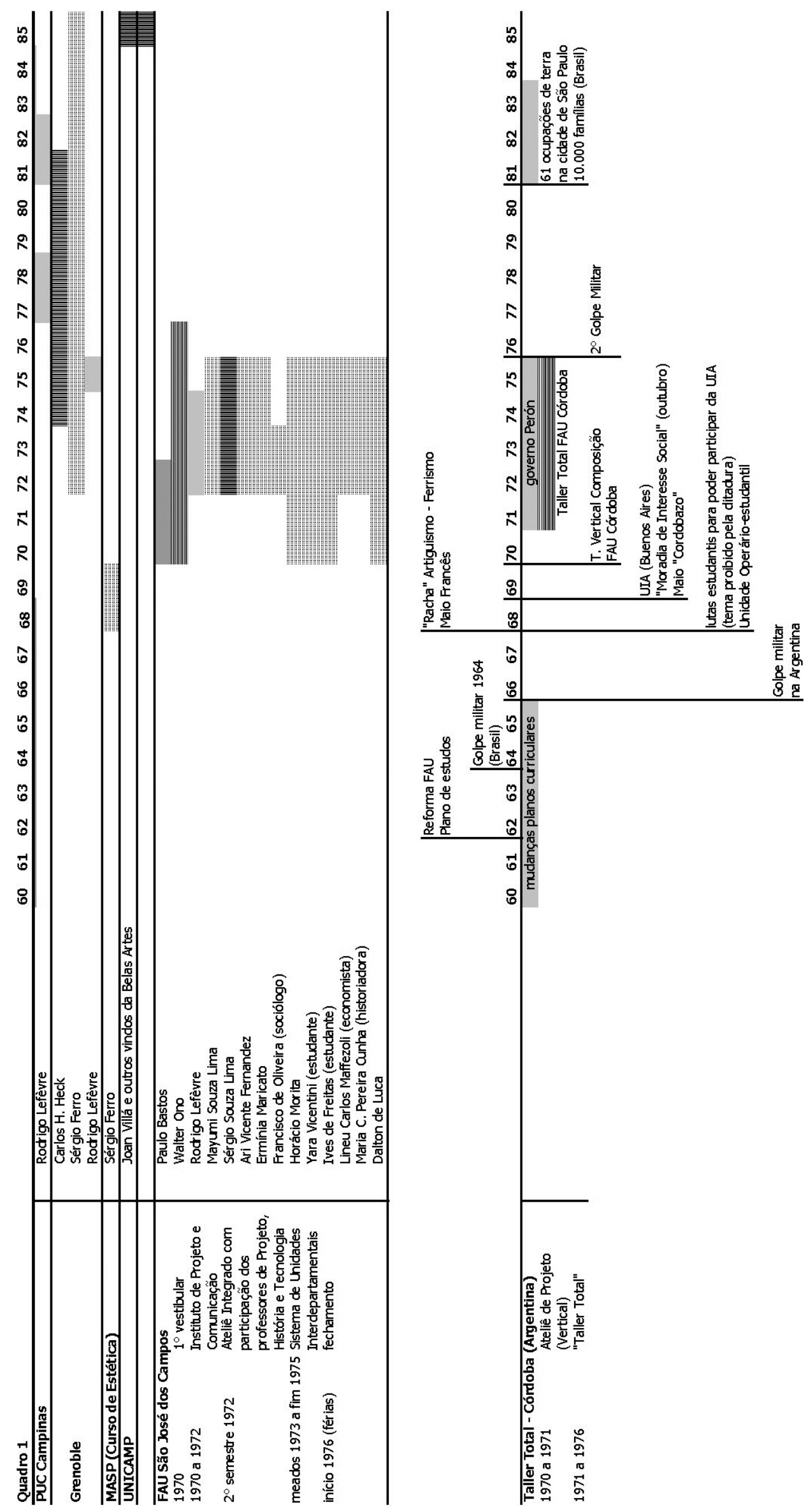
As características e circunstâncias em que esse grupo se desenvolveu, assim como as particularidades de suas propostas, serão analisadas na Parte II. Em seguida se fará uma análise mais detalhada e profunda da FAU-SJ C, considerada "uma das experiências mais importantes no ensino de arquitetura no Brasil, fechada em circunstâncias muito pouco explicáveis", nas palavras do professor e arquiteto Miguel Pereira, em conferência proferida na abertura do IV Seminário do Curso de Arquitetura da Faculdade de Belas Artes de São Paulo, em 1983. Na mesma conferência, ele destacou a FAU-UNC, que em Córdoba, Argentina, nos anos 1970, desenvolveu a experiência do Taller Total (ateliê total), pelo que ficou conhecida em toda a América Latina: “[...] essas idéias vieram para o Brasil e a gente conseguiu colocar em pauta algumas experiências, dentre elas a de Brasília [após sua reabertura em 1968], que tentou repetir a idéia do ateliê total"2.

Pelas razões enunciadas acima, e por considerá-la uma experiência pioneira e democrática, da qual participei, a FAU-UNC comparecerá em outro capítulo, onde tentarei estabelecer uma análise comparativa com a FAU-SJ C, destacando que as duas experiências de ensino de arquitetura se deram de forma simultânea, porém em lugares diferentes: uma no Brasil, sendo em instituição privada (FAU-SJC), e a segunda na Argentina, em instituição pública (FAU-UNC).

As experiências de ensino de arquitetura brasileiras não ocorreram de forma isolada; eram umas referências das outras, direta ou indiretamente. O conjunto delas constituiu, na minha visão, um movimento onde se verificou uma acumulação - embora estivessem inseridas em momentos diversos, pertenciam a um tempo político com continuidade e abrangência estratégica dentro do processo de globalização do Brasil. E tentaram, com visão crítica, dar respostas no plano específico às situações político-sociais, no contexto da

\footnotetext{
${ }^{2}$ Pereira, M., 2005: 80-82. O arquiteto Miguel Pereira foi diretor da Faculdade de Arquitetura e Urbanismo de Brasília de 1968 a 1976.
} 
privatização do ensino, no período que foi dos anos anteriores ao golpe militar até a década de 1980, já na fase da democratização do país. Considerei necessário, com o intuito de investigar de forma mais profunda essas experiências de ensino de arquitetura e urbanismo, fazer uma análise das políticas de ensino superior no Brasil em seu contexto histórico, vinculado ao latino-americano, e suas principais referências mundiais, já que a pesquisa bibliográfica levou-me a perceber a existência de uma profunda e complexa relação entre as políticas de ensino universitário na América Latina, no marco do processo de internacionalização do capital.

Isso permitirá, posteriormente, verificar como os diversos aspectos do contexto histórico dos anos 1960-1970 produziram reflexos diferentes no plano da arquitetura e urbanismo e seu ensino. Isso vai possibilitar entender 0 acirrado debate produzido nesses anos na FAU-USP, considerado um marco para o entendimento dessa época ${ }^{3}$, e que ocorria também na FAU- SJC. Esse debate está implícito nos artigos "Proposta inicial para um debate: possibilidades de atuação", de Sérgio Ferro e Rodrigo Lefèvre (publicado pelo Grêmio da FAU-USP em 1963); "Uma falsa crise", de Vilanova Artigas (publicado em 1965); "Uma crise em desenvolvimento", de Rodrigo Lefèvre (publicado em 1966); "Arquitetura Nova", de Sérgio Ferro (publicado em 1967), assim como a aula inaugural de Vilanova Artigas em 1967. Uma das manifestações mais significativas desse debate talvez seja o aparecimento simultâneo de duas revistas de estudantes da FAU-USP, O Desenho e Ou..., em 1970.

\footnotetext{
${ }^{3}$ Entre outros, depoimento de Carlos Martins in Koury, 2005: 18; informações fornecidas por Carlos H. Heck, Luiz Ackel, Raul Pereira e Paulo Bastos em São Paulo, em 2006.
} 


\section{Copítulo 1}

\section{SUBDESENVOLVIMENTO E CAPITALISMO}

O estudo realizado por Francisco de Oliveira no livro Crítica à razão dualística contém uma reflexão que permite entender o período dos anos 1960 e 1970 no Brasil e que, em minha visão, pode se estender a muitos países latino-americanos, apesar de suas especificidades. A análise desse autor focaliza as transformações estruturais do Brasil pósanos 1930 - que permitem a expansão do modo capitalista de produção -, rompendo com o conceito de modo de produção subdesenvolvido, formação histórico-econômica que polariza, de um lado, um setor "atrasado" e, de outro, um "moderno". Oliveira esclarece que essa é uma dualidade que não se sustenta, já que se encontra em quase todos os períodos e na maioria dos sistemas, sendo essa oposição quase sempre apenas aparente, enquanto o processo real mostra uma unidade de contrários, uma simbiose em que o "atrasado" alimenta e nutre o "moderno" 4 .

Essa reflexão de Francisco de Oliveira remete à noção de que 0 processo de desenvolvimento capitalista é desigual e combinado. A idéia de subdesenvolvimento como "trânsito" para formas mais avançadas do capitalismo não leva em consideração que o subdesenvolvimento é na verdade uma "produção" do capitalismo em expansão. Em pouquíssimos casos, por exemplo, os do Peru e do México, pode-se falar em absorção de modos de produção mais antigos pelo capitalismo. Na maior parte dos casos, a própria expansão do capitalismo mundial foi responsável pela criação das economias pré-

\footnotetext{
${ }^{4}$ Oliveira, F. de, 2006: 29-32.
} 
industriais da América Latina. Em outras palavras, o

\section{subdesenvolvimento está incluído na formação capitalista5.}

Para Oliveira, o desenvolvimento ou crescimento diz respeito à oposição de classes no interior do país e não a uma oposição entre nações, tal como se teorizou muitas vezes. Ele considera que a teoria do desenvolvimento colaborou, no Brasil, para dificultar a elaboração de uma teoria sobre o capitalismo, deixando no escuro a possibilidade de distinguir a quem serve o desenvolvimento econômico capitalista. Com expressões tais como "desenvolvimento auto-sustentado", "integração nacional", "planejamento", "interesse nacional", o desenvolvimentismo se apoiou na teoria do subdesenvolvimentismo, que foi a ideologia do período populista.

\section{Desenvolvimentismo}

Para entender o contexto desse período será preciso falar brevemente da teoria desenvolvimentista, dos órgãos que a instrumentalizaram e de sua relação com as políticas públicas de educação universitária.

O desenvolvimentismo surgiu no momento político-econômico pósSegunda Guerra Mundial, passando em pouco tempo a se configurar como idéia matriz ${ }^{6}$ de uma estratégia que visava rearticular a hegemonia do capital, liderada pelos Estados Unidos, que, com o pleno acordo das elites latino-americanas, apoiava-se no discurso de que ela permitiria superar o "atraso" dos denominados "países em vias de desenvolvimento".

A Segunda Guerra Mundial assistiu, muito mais intensamente que a primeira, ao avanço da técnica e da ciência e aos efeitos da destruição em massa que proporcionaram, cujo ponto culminante foram os bombardeios aéreos e a bomba atômica. Portanto, a esperança no

\footnotetext{
${ }^{5}$ Ibid.: 32-33, grifo nosso.

${ }^{6}$ Frigotto, 1993 apud Machado, 2006: 190.
} 
progresso e numa vida melhor tinha suas bases fincadas no horror da mortífera realidade.

Como diz Nicolau Sevcenko ${ }^{7}$, com o fim da guerra os Estados Unidos ficaram numa situação privilegiada, com sua economia mais forte e coesa; seu governo organizou um amplo plano para apoiar a recuperação das economias capitalistas européias ocidentais, no contexto da guerra fria e concorrendo com o bloco recém-ampliado dos países socialistas. Na Ásia, na África e na América Latina as agitações revolucionárias provocaram investimentos dos norte-americanos, que em sua condição de liderança, patrocinaram também tratados multilaterais visando garantir mercados estáveis, reduzir as barreiras alfandegárias e o protecionismo, consolidando ainda mais sua hegemonia.

\section{A Comissão Econômica para América Latina (Cepal)}

Como parte da política descrita acima, em 1948 criou-se a Comissão Econômica para América Latina (Cepal), que dá início a uma tentativa de integração latino-americana, que teve continuidade na década de 1960 com a gestação da Associação Latino-americana de Livre Comércio (ALALC) e do Mercado Comum Centro Americano (MCCA) ${ }^{8}$. Tratava-se, porém, de uma perspectiva de integração que tentava legitimar, também por meios culturais e educacionais, como se verá adiante, a ação econômico-social das classes mais abastadas, no marco do processo de acumulação capitalista na América Latina, e em particular no Brasil.

Mesmo a Cepal $^{9}$, que via a teoria desenvolvimentista como possibilitadora de um desenvolvimento autônomo ao considerar que 0

\footnotetext{
${ }^{7}$ Sevcenko, Nicolau, 2001: 25.

${ }^{8}$ Acordos posteriores, tais como o Pacto Andino (1969), Associação Latino-americana de Integração (Aladi - 1980), Mercado Comum do Sul (Mercosul - 1991) e, atualmente, a Área de Livre Comércio da América (ALCA), confirmam essa tendência. Dados de MACHADO, A. da Silva, 2006: 189-190.

${ }^{9}$ Machado, A. da Silva, 2006: 189-190.
} 
problema não era o capitalismo em si mesmo, mas a forma como estava sendo aplicado, acabava referenciando a política norteamericana. Francisco de Oliveira alerta para o fato de que o estilo de interpretação ao qual se costumou associar a industrialização tanto na América Latina quanto no Brasil, e que fornece as bases para uma tímida teoria da integração latino-americana, privilegia as relações externas das economias capitalistas da América Latina, e nesse diapasão, transforma a teoria do subdesenvolvimento numa teoria da dependência ${ }^{10}$.

\section{A OEA e as políticas públicas de ensino superior}

Uma breve referência à atuação da OEA, especialmente nas décadas de 1960 e 1970, permitirá entender melhor sua relação com as políticas públicas de educação superior.

Na criação de programas específicos para a América Latina, os interesses da OEA ${ }^{11}$ estavam expressos na Carta de Punta del Este de 1961, que incluía a Aliança para o Progresso dentro da estrutura da Operação Pan-americana; numa de suas resoluções, a Aliança para o Progresso estabelecia o Plano Decenal de Educação, que continha diretrizes educacionais para a América Latina, posteriormente reforçadas na Declaração dos Presidentes da América por meio dos Programas Regionais da Educação, em 1967.

A Aliança para o Progresso foi uma estratégia utilizada por Kennedy em 1960, ao perceber que a esperança contida na vitória da revolução cubana poderia estender-se para a América Latina. Como estava claro que a pura repressão não poderia vencer essa esperança, resolveu criar um instrumento ideológico destinado a "extirpar o germe revolucionário nesse continente"12. Era preciso também melhorar a imagem dos Estados Unidos, deteriorada pela frustrada tentativa de intervenção em

\footnotetext{
${ }^{10}$ Oliveira, F. de, 2006: 49.

${ }^{11}$ Machado, A. da Silva, 2006: 191.
} 
Cuba em 1961 e pelas constantes intervenções em países latinoamericanos $^{13}$. 0 entrelaçamento desses objetivos deu origem a duas iniciativas: a criação em 1961 da US Army School of the Americas (Escola do Exército Americano para as Américas) no canal do Panamá, que formava militares provenientes dos países da América Latina, capacitando-os a realizar sua própria guerra contra-revolucionária sem precisar de intervenção explícita dos Estados Unidos ${ }^{14}$; e a implantação da Faculdade Interamericana de Educação, que funcionou de 1970 a 1977 (na verdade um curso de pós-graduação), instalada na Universidade Federal de Santa Maria (UFSM) no interior do estado do Rio Grande do Sul ${ }^{15}$.

Alexander da S. Machado esclarece que essa faculdade não foi imposta pela OEA, apesar do projeto de criação envolver o objetivo de criar um aparelho ideológico; foi implantada a pedido do reitor da UFSM e do Ministério de Educação e Cultura do Brasil, na reunião do Conselho Interamericano Cultural $(\mathrm{ClC})$, órgão pertencente à $\mathrm{OEA}$, que tinha incentivado a elaboração de projetos inspirados na Aliança para o Progresso. 0 processo de implantação vinha ao encontro dos objetivos do MEC de formar professores capacitados para desenvolver as reformas educacionais que se anunciavam (e que serão ainda tratadas com mais detalhes adiante).

Para o programa proposto por Kennedy, a OEA teve importância fundamental, conseguindo, em reunião extraordinária, sua aprovação no Conselho Interamericano Econômico e Social, legitimando assim a nova política proposta em 1960 para as relações com os países da América Latina.

A Aliança para o Progresso teve como base pesquisas realizadas por Lincoln Gordon, cuja avaliação indicava a conveniência de reduzir as desigualdades sociais no continente para diminuir os argumentos

\footnotetext{
${ }^{12}$ Shilling, 1991, apud Machado, A. da Silva, 2006: 192.

13 Machado, A. da Silva, 2006: 192.

${ }^{14}$ Ibid.
} 
incentivadores de revoluções que seguissem o exemplo cubano; para isso, os Estados Unidos deveriam liderar uma revolução social pacífica que em dez anos pudesse transformar os países latino-americanos, evitando sublevações ${ }^{16}$ e mantendo a hegemonia do capital. Esses países deveriam alcançar determinadas metas e cabia ao setor educativo legitimar e sustentar as mudanças propostas ${ }^{17}$.

Com o discurso da geração do desenvolvimento, a Aliança para o Progresso propunha uma modernização por meio da capacitação de mão-de-obra qualificada e da modificação do ensino; essa perspectiva foi legitimada no Brasil por meio do estabelecimento de um processo de "ajuda" entre o MEC e a USAID, que se iniciou na década de 1970, mas que, quanto a financiamentos e acordos, tinha tomado maiores proporções no Brasil já a partir do golpe militar de $1964^{\mathbf{1 8}}$, que desenvolveu uma nova política econômica comprometida com o capitalismo.

A política de relações entre Estados Unidos e países latino-americanos por meio dos acordos MEC/USAID e Aliança para o Progresso tinha ainda outra conseqüência: o aumento do endividamento desses países para com os Estados Unidos, pois a cobrança dos recursos financeiros aplicados nos programas de "ajuda" recaía em suas já avultadas contas de débitos ${ }^{19}$.

Segundo Machado, foi assinada em Punta del Este, Uruguai, a Declaração dos Presidentes da América, que definia a criação e a ampliação de cursos de pós-graduação por meio de escolas de especialização, por ser o setor de educação considerado de alta

\footnotetext{
${ }^{15}$ Machado, A. da Silva, 2006: 191.

16 Ibid: 192.

${ }^{17}$ Ibid.

${ }^{18}$ Ibid.: 193, grifo nosso.

${ }^{19}$ Ibid.: 193-194. Em julho de 1964 assinou-se o acordo MEC/ USAID com o objetivo do aperfeiçoamento do ensino primário, com a assessoria de seis norte-americanos por dois anos. Em março de 1965 assinou-se o segundo acordo entre MEC/ CONTAP (Conselho de Cooperação Técnica da Aliança para o Progresso/ USAID) para melhorar o ensino médio, com apoio e assessoria técnica norte-americana e treinamento de técnicos brasileiros nos Estados Unidos.
} 
prioridade na política de desenvolvimento dos países latino-americanos (OEA, 1967). Esses programas visavam promover a integração educacional na América Latina e pretendiam o planejamento de um sistema adaptado às exigências do desenvolvimento econômico, social e cultural para preparar mão-de-obra qualificada, vista como necessário instrumento de apoio ao crescimento econômico.

No enfoque desenvolvimentista, o problema da desigualdade tendia a ser abordado com a qualificação da mão-de-obra; assim, a educação era apontada como fator principal na eliminação das desigualdades sociais $^{20}$. O raciocínio de que uma maior qualificação possibilitaria mais produtividade - aumentando a renda do trabalhador e diminuindo as grandes diferenças sociais - alimentava o discurso de que cabia à educação, à cultura e à ciência o papel de integradores regionais ${ }^{21}$, de panacéia para a superação das desigualdades entre nações, regiões e classes sociais. Era a supervalorização do conhecimento para as transformações dos setores produtivo e sociais, quando, na verdade, 0 conhecimento interessava apenas se gerasse lucro e não questionasse os valores instituídos, ou seja, as diferenças decorrentes do sistema capitalista. Nesse contexto é possível entender a teoria do capital humano ${ }^{22}$ como parte específica da teoria desenvolvimentista, adotada pela maior parte dos países da América Latina como proposta para alcançar o desenvolvimento e diminuir as desigualdades, porém sem alterar as estruturas de dominação.

Em síntese, pode-se afirmar que a Cepal e a OEA vislumbravam um crescimento para a América Latina baseado em políticas econômicas e sociais que se inseriam, de acordo com seus pressupostos, numa "planificação séria e inteligente" que visava metas a serem alcançadas pelo desenvolvimento; exemplo dessa aposta na planificação foi a Aliança para o Progresso - apoiada pela Cepal e aprovada pela OEA -,

\footnotetext{
${ }^{20}$ Machado, A. da S., 2006: 198.

21 Ibid.

22 Ibid.: 204.
} 
cujo planejamento econômico relacionava-se ao projeto educacional, que orientava o investimento em tecnologia, análise e difusão de inovações, novos padrões de consumo, aprimoramento empresarial, propensão à poupança e adaptabilidade a mudanças econômicas, assim como o fornecimento de mão-de-obra qualificada profissional e técnica ${ }^{23}$.

\section{Os anos 1950 e a independência das FAUs}

Entre o final dos anos 1940 e o início dos anos 1950 definiu-se a independência das escolas de Arquitetura que até então estavam integradas às escolas de Engenharia ou às das Belas Artes. Criou-se no Rio de Janeiro a Faculdade Nacional de Arquitetura (1946), que se desprendeu da Escola de Belas Artes; em São Paulo, a Faculdade de Arquitetura da Universidade Presbiteriana Mackenzie, que se separou da Engenharia em 1947; em 1948, a Faculdade de Arquitetura e Urbanismo da Universidade de São Paulo tornou-se independente da Escola Politécnica; no Rio Grande do Sul, formou-se a Faculdade de Arquitetura da Universidade Federal do Rio Grande do Sul (UFRS), em 1952, após intensa mobilização de estudantes e professores, a partir da reunião dos cursos de arquitetura existentes no Instituto de Belas Artes e na Escola de Engenharia; as Faculdades de Arquitetura das Universidades Federais de Minas Gerais, Bahia e Pernambuco foram inauguradas nesses anos. Devido à sua origem e ao contexto no mundo e no Brasil em que se formaram essas novas Faculdades de Arquitetura, elas herdaram, na opinião de Miguel Pereira, o esquema de organização e a valorização do formalismo, no caso das que provinham das Escolas de Belas Artes, ou a supervalorização da técnica naquelas originadas das Escolas de Engenharia, assim como a falta de integração entre as diversas disciplinas ${ }^{24}$.

\footnotetext{
${ }^{23}$ CEPAL, 1974, apud Machado, A. da Silva, 2006: 204. Segundo a maioria das fontes consultadas é nesse contexto que a reforma de 1968 da FAU-USP foi realizada.

${ }^{24}$ Pereira, M., 2005: 111. Ver também Albuquerque, 2004.
} 
Em 1956 iniciou-se a construção de Brasília, inaugurada em 1960, e com sua universidade (UnB) criada em 1962. Surgiram em São Paulo, na FAU-USP, e no Rio Grande do Sul, na FAU-UFRS, propostas de reformulações de ensino de arquitetura ${ }^{25}$, fruto de seminários nacionais, latino-americanos e mundiais.

\footnotetext{
${ }^{25}$ Ibid. A proposta de reformulação de ensino de arquitetura realizada na FAU-UFRS foi uma referência importante, porém foge ao escopo desta tese.
} 
Copítulo II

ACUMULAÇÃO $\in$ PAISAGEM NAS PERIFERIAS URBANAS

Tanto no Brasil como na América Latina em geral, há uma visão corrente que associa a industrialização de um país - em substituição à política de importações - a um processo de independência em relação ao capital internacional. Como se ela tivesse surgido para suprir uma necessidade de consumo da população em vez da necessidade de acumulação do capital; e as formas de consumo são vistas desvinculadas da estrutura de classes, analisadas em abstrato. $\mathrm{Na}$ verdade, a industrialização aconteceu principalmente para atender às necessidades de acumulação, sem promover transformações nas relações entre as classes sociais ${ }^{26}$. Na minha visão, isso permite entender o processo de formação da paisagem nas periferias das cidades e suas características nos planos da habitação, do loteamento clandestino, entre outros, questões que foram preocupações centrais nas experiências de ensino de arquitetura aqui analisadas e que serão discutidas em outro capítulo.

Nesse sentido, quando existe uma grande massa urbana que é a força de trabalho industrial e também de serviços, é fundamental para o capital conservar baixo o custo de reprodução da força de trabalho com o objetivo de que o investimento não seja ameaçado; faz-se então necessário produzir bens que se incluem no custo da reprodução dessa força de trabalho porque, entre gastar divisas para mantê-la e criar a opção de produzir internamente, a balança pesará para a última alternativa. No Brasil o processo foi desta forma: de início foram

\footnotetext{
${ }^{26}$ Oliveira, F. de, 2006: 50.
} 
produzidos internamente os bens de consumo não duráveis para as camadas populares e, posteriormente, os bens de consumo duráveis ${ }^{27}$. Nesse processo, segundo Francisco de Oliveira, houve uma enorme ampliação do "exército industrial de reserva", assim como aumento das taxas de exploração, o que contribuiu para reforçar a acumulação.

\section{Passagem de ciclos}

Para Francisco de Oliveira, na economia brasileira iniciou-se um ciclo a partir da Revolução de 1930, com uma predominância produtiva cuja base passou a ser urbano-industrial. Porém só em 1956 a renda proveniente da agricultura foi superada pela industrial ${ }^{28}$.

A passagem de ciclo predominantemente agro-exportador para o ciclo de base urbano-industrial em 1956 foi um processo que exigiu do país inúmeras reformulações sociais, políticas e econômicas que podem ser sintetizadas em:

- Nova relação de forças sociais.

- Reformulação do aparelho estatal e de suas ações.

- Novas regulamentações de fatores tais como o preço do trabalho, de forma que se deu, por um lado, a destruição das regras do jogo pelas quais as atividades agro-exportadoras foram privilegiadas e, por outro lado, criaram-se condições institucionais para a expansão das atividades ligadas ao mercado interno ${ }^{29}$.

Muitos intelectuais de esquerda latino-americanos, ao analisar essa passagem, não levavam em consideração que ela não pode ser entendida, como diz Oliveira, de um ponto de vista que isole as condições econômicas das políticas; assim, esses intelectuais dilaceravam-se num argumento com duas proposições opostas: se por um lado denunciavam as condições de extrema pobreza da maioria da

\footnotetext{
${ }^{27}$ Oliveira, F. de, 2006: 50.

28 Ibid.: 35.

29 Ibid.
} 
população latino-americana, suas análises e teorias ficavam presas a debates circunscritos à relação produto-capital, volume de mercado, capacidade de investimento ou de poupança. Isso os levava a elaborar "o estranho mundo da dualidade e a desembocar a contragosto na ideologia do círculo vicioso da pobreza"30; e, ao opor a "sociedade moderna" à "sociedade tradicional", contribuíam para criar uma dualidade que conduziu, nas palavras de Oliveira, "boa parte dos esforços na sociologia e na ciência política a uma espécie de beco sem saída"31.

A expansão do mercado interno se concretizou já no ano 1956, quando foi implantada a indústria automobilística, com a produção dos primeiros carros nacionais Mercedes Benz e Vemag e a fundação da Volkswagen do Brasil. E também teve início a construção de Brasília. Na industrialização brasileira após 1930, a nova legislação trabalhista com a instituição do salário mínimo em 1936 - garantia ao empregador o benefício da 'formação de um enorme 'exército de reserva' propício à acumulação"32. A legislação definia o salário mínimo de forma rigorosa como salário de reprodução ou de simples subsistência, sem que existisse, em seus critérios, incorporação dos ganhos de produtividade do trabalho ${ }^{33}$. Não há dúvida, afirma Oliveira, de que as leis trabalhistas faziam parte das medidas que visavam organizar um novo modo de acumulação. Assim, a população que chegava em grandes quantidades às cidades precisava ser transformada em "exército de reserva" apropriado à reprodução do capital, o que era necessário do ponto de vista da acumulação que em certo sentido se iniciava e que se queria reforçar ${ }^{34}$.

Trinta anos depois de formuladas as idéias a que fiz referência acima, Francisco de Oliveira retomou o tema em 0 ornitorrinco, numa reflexão

\footnotetext{
${ }^{30}$ Oliveira, F. de, 2006: 30-31.

${ }^{31}$ Ibid.

32 Ibid.: 38.

${ }^{33}$ Ibid.: 37-39.

${ }^{34}$ Ibid.: 38.
} 
sobre essas teorias que envolvem a luta contra o subdesenvolvimento e o "monstrengo social" em que o Brasil converteu-se. Nesse texto, 0 autor afirma que agricultura de subsistência, financiamento da acumulação industrial, sistema bancário e barateamento da reprodução da força de trabalho nas cidades formavam um conjunto imbricado que dava apoio ao processo de expansão capitalista, processo que a produção teórica do grupo cepano-furtadista não percebia, apesar de seu método intenso de perguntas e respostas visando encontrar explicações ${ }^{35}$.

Discordando das teorias que enxergavam no atraso da agricultura um impedimento ao processo de industrialização, no "inchaço" das cidades a condição de marginalidade e na incompatibilidade da legislação que definia o salário mínimo em relação à acumulação de capital, o autor entende que a fraqueza dos fundamentos para a própria expansão capitalista estava, e ainda está, na má distribuição de renda e que esse é o obstáculo ao desenvolvimento da acumulação ${ }^{36}$.

\section{Exército de reserva, mutirões e a paisagem das favelas}

No período em que Francisco de Oliveira formulou as idéias citadas acima, trabalhava como professor na Faculdade de Arquitetura de Santos. Ele conta que "ensinava sociologia na nova Faculdade de Arquitetura de Santos, com Sergio Ferro, rigor formal e paixão, e o inesquecível Rodrigo Lefèvre, o dançarino das Sandálias de Prata que a madrasta levou, e eles realizavam com outros professores uma pesquisa sobre habitação. Ali se constatava que a grande maioria dos favelados era proprietária de seus barracos: a incógnita foi resolvida com a revelação de que a construção da 'propriedade' era feita em

\footnotetext{
${ }^{35}$ Oliveira, F. de, 2006: 130.

${ }^{36}$ Oliveira, F. de, 2006: 130.
} 
mutirões, tal como imemorialmente se fazia no campo. Aí, me caiu a ficha"37.

Essas constatações empíricas levaram a desvendar ainda mais o papel do 'exército de reserva' das grandes cidades. Se a maior parte dos teóricos o via como o lúmpen ou o consumidor de excedentes, esse exército tinha para Oliveira uma outra função: ao exercer seu trabalho informal, fazia parte dos meios para rebaixar o custo de reprodução da força de trabalho urbano.0 paradoxo de que os operários, em especial os que tinham se constituído como tal no período da industrialização desde 1950, e outras camadas da população de baixa renda eram proprietários de suas moradias, inseridas na paisagem da favela, reduzindo assim o valor monetário de sua própria reprodução ,ficou explicado pelo papel que o mutirão e a autoconstrução cumprem nesse processo de rebaixamento do valor do trabalho ${ }^{38}$.

Também Sergio Ferro desenvolveu esse conceito em "A casa popular", em 1969. Tanto ele quanto Oliveira referenciaram-se na obra $A$ questão da habitação, de Engels. Este último, porém, não distinguiu as diferentes formas de produção da habitação; para ele, ao suprimir o aluguel, diminui o valor da reprodução da força de trabalho, reduzindose concomitantemente os salários ${ }^{39}$.

\section{O inchaço do terciário}

Para os teóricos do subdesenvolvimento, uma das características do que denominavam "modo de produção subdesenvolvido" seria ter um terciário 'inchado', que se apresentaria como um peso morto na formação do produto, gastando o excedente ${ }^{40}$.

\footnotetext{
${ }^{37}$ Ibid. Esse depoimento interessa nesta pesquisa por estar relacionado a uma das experiências de ensino selecionadas, sendo forte referência da FAU-SJC. Retomar-se-á a análise desse depoimento em outro capítulo.

38 Ibid.

${ }^{39}$ Ibid. Não cabe aqui realizar um diálogo com as idéias desenvolvidas por Harvey, 1986, a respeito do ambiente construído na Europa, mas vale lembrar que esse assunto também é tratado por Arantes, 2002, 189-190.

${ }^{40}$ Oliveira, F. de, 2006: 53.
} 
Mas, no Brasil, o terciário é o setor que mais concentrou os aumentos da força de trabalho, diz Oliveira, que, contra a idéia da "inchação do terciário" e do "segmento marginal da economia", defendeu em 1972 a seguinte hipótese:

“O crescimento do terciário, na forma em que se dá, absorvendo crescentemente a força do trabalho [...] faz parte do modo de acumulação urbano adequado à expansão do sistema capitalista no Brasil; não se está em presença de nenhuma 'inchação' nem de nenhum segmento 'marginal' da economia"41.

No Brasil, a indústria como epicentro da aceleração do crescimento demanda das cidades - que são o principal lugar dessa nova expansão uma infra-estrutura e serviços para os quais não estavam preparadas ${ }^{42}$. Para entender melhor esse processo é preciso lembrar que, por um lado, o crescimento industrial foi muito intenso ${ }^{43}$ e, por outro, a capitalização dos serviços não é simultânea, o que evitou a concorrência entre ambos "pelos escassos fundos disponíveis para a acumulação capitalista"44 . O setor terciário então se desenvolveu de forma "atrasada", produzindo aqui também a simbiose entre "moderno e atrasado"45 de que se falou anteriormente. 0 que não é contraditório nem impedimento à expansão global da economia, na visão de Oliveira, e nesse processo a "inchação" aparente contribuiu para esconder uma das formas mais importantes da acumulação: a realização de serviços baseados na força de trabalho pura, com baixíssimo pagamento, transferindo constantemente uma parte de seu valor (parte da maisvalia) para as atividades econômicas propriamente capitalistas.

No Brasil, como na maioria dos países da América Latina, o processo de crescimento das cidades só pode ser entendido se considerarmos que

\footnotetext{
${ }^{41}$ Ibid.: 54-55.

42 Ibid.: 56.

${ }^{43}$ Sua participação no produto bruto passa de 19\% a 30\% em 30 anos ,apud Oliveira, F. de, 2006: 56.

44 Ibid.

${ }^{45}$ Essa simbiose se verifica também entre a moderna agricultura e o comércio de ambulantes, diz Oliveira (2006: 56); na minha visão está ainda hoje presente na paisagem urbana brasileira.
} 
as necessidades da acumulação econômica tornam obrigatório o desenvolvimento horizontalizado de serviços, que se apresenta na aparência como caos na paisagem das cidades. Oliveira ${ }^{46}$ chama a atenção para não confundir anarquia com caos, porque a aparente anarquia do crescimento urbano não é sinônimo de caótico frente às exigências da acumulação.

Dito em outras palavras, a paisagem caótica e anárquica das periferias urbanas brasileiras e na maioria das latino-americanas revela as exigências da acumulação capitalista nesses países. Como afirma 0 autor, nas reais condições materiais descritas, "o sistema caminhou inexoravelmente para uma concentração de renda, da propriedade e do poder"47, com a particularidade, no Brasil, de que 0 avanço do capitalismo introduziu relações novas no arcaico e repetiu relações antigas no novo ${ }^{48}$. Isso traduz, em outras palavras, a idéia, cunhada por Trotsky, do desenvolvimento desigual e combinado no capitalismo.

As idéias citadas acima revelam, segundo Oliveira, as formas não resolvidas do acesso à terra no Brasil e também no estatuto das forças do trabalho, assim como a dependência ao estado dessa nova classe social que se forma nas cidades. Recusando as explicações da Cepal referentes ao dualismo "atraso-modernismo" como polaridades opostas, entende que o subdesenvolvimento é a forma de exceção permanente do sistema capitalista nas periferias de suas cidades ${ }^{49}$.

A discussão e teorização de subdesenvolvimento e desenvolvimentismo realizada até aqui será retomada adiante com o objetivo de esclarecer em que medida e de que maneira essa questão permeou as idéias, seja na arquitetura e urbanismo, seja no seu ensino e na atuação dos partícipes das experiências selecionadas e citadas anteriormente e particularmente na FAU-SJ C, objeto de trabalho desta tese.

\footnotetext{
${ }^{46}$ Oliveira, F. de, 2006: 59.

${ }^{47}$ Ibid.: 60 .

${ }^{48}$ Oliveira, F. de, 2006: 60.

${ }^{49}$ Ibid.: 131.
} 


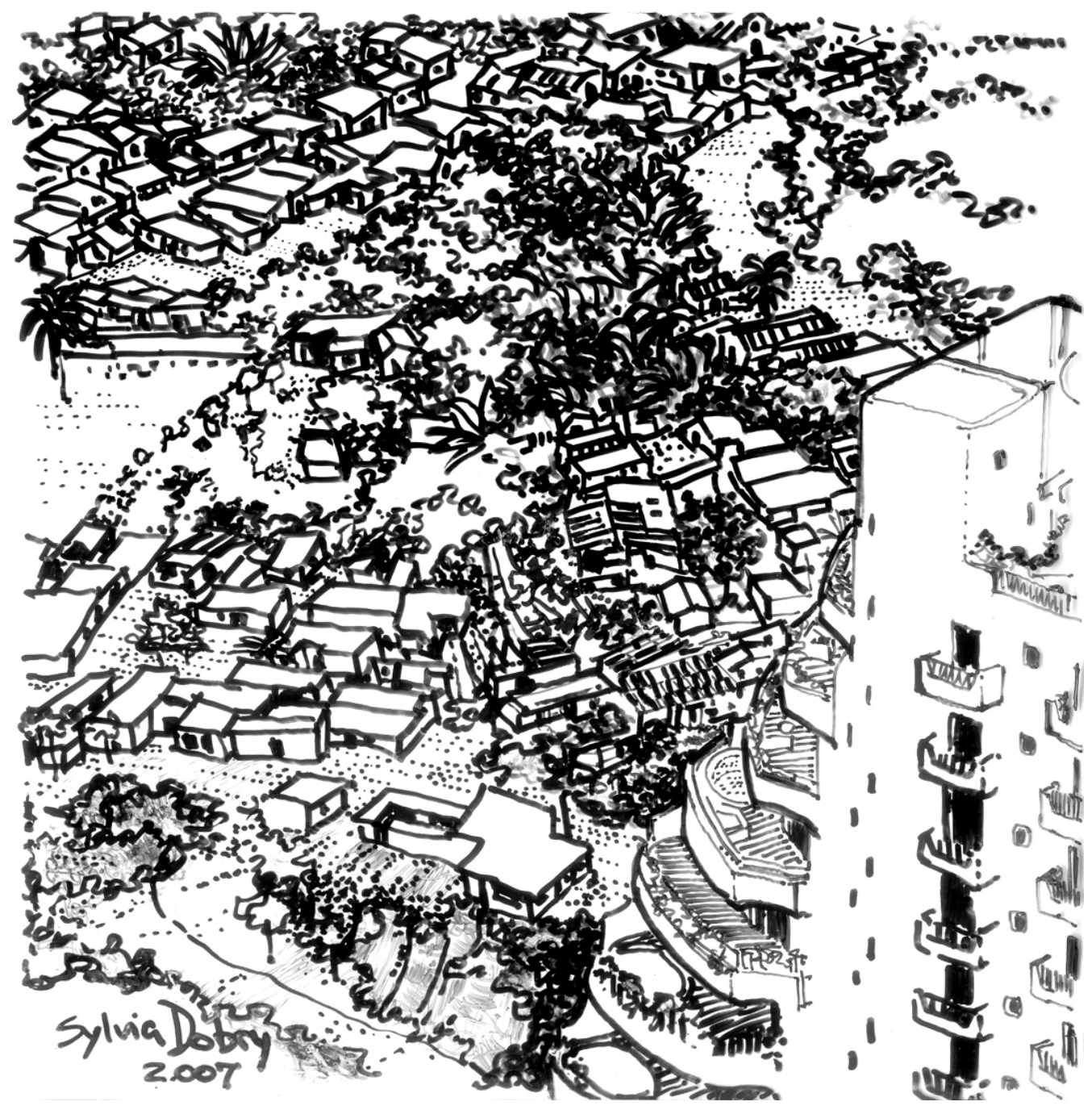

Desenho realizado com base em fotografia de Celio $\mathrm{J}$.

Publicada por Maricato, Ermínia, 1997: capa. 
Parte II

O ENSINO DE ARQUITETURA E URBANISMO

\section{Considerações iniciais}

Ao centrar o objeto de trabalho na FAU-SJ C, cuja existência vai de 1970 até 1976, constatou-se que a mesma nasceu no início do processo de privatização do ensino superior no Brasil. Por isso, considerou-se pertinente estender a pesquisa sobre as políticas públicas de ensino superior, ampliando sua abrangência até a década de 1990 no intuito de entender a gênese da atual.

Um dado importante para entender o contexto em que essas experiências aconteceram, observado na pesquisa bibliográfica e nos depoimentos analisados, foi a forte presença das teorias de cunho marxista nesse período, em especial nos meios intelectuais e estudantis.

Com base no livro Pela mão de Alice - o social e o político na pósmodernidade, de Boaventura de Sousa Santos, em especial os dois primeiros capítulos, foi possível perceber, a partir do enfoque de diferentes épocas realizado pelo autor, a diversidade de visões do marxismo que influenciaram os atores do processo analisado e seu contexto, focado nos anos 1960 a 1970, em que se inclui o emblemático 1968, até meados dos anos 1980. 


\section{Capítulo 1 \\ AS POLITICAS PÚBLICAS DE ENSINO SUPERIOR}

Muito do que se tem escrito recentemente sobre as reformas de Estado e da educação superior em outros países, em especial os latinoamericanos, apresenta semelhanças com as mudanças brasileiras. É possível perceber, pelos textos analisados, que o processo em curso, que envolve enfraquecimento do Estado e crescimento das privatizações, em especial no plano universitário, tem estreita relação com o grau de avanço das conquistas democráticas alcançadas pelos diferentes países e com suas situações político-econômicas. Poder-se-ia indagar em que medida o que ocorre no Brasil se assemelha (com as devidas particularidades) ao que ocorre em outros países da América Latina, como Chile, Equador, Argentina, Colômbia etc ${ }^{1}$. A resposta a essa indagação excede os objetivos deste trabalho, porém a quase certeza das semelhanças se mantém como pano de fundo, numa época em que não é conveniente olhar a história contemporânea sem visualizar as possíveis conexões entre os países da América Latina e do mundo.

Para o desenvolvimento do tema Políticas Públicas de Ensino Superior selecionou-se como referência fundamental a extensa pesquisa realizada por J oão dos Reis Silva J r. e Valdemar Sguissardi, por abranger os aspectos mais densos e centrais do contraditório processo de reforma e redisposição do sistema de educação superior no Brasil, tanto público quanto privado, e por sua coerência com o significado de subdesenvolvimento e desenvolvimentismo baseado na análise de Francisco de Oliveira.

\footnotetext{
${ }^{1}$ Extensa literatura trata desse tema, entre outros Arango, Diana Soto e Jardilino, Rubens Lima (org.), 2006, Silva Jr., João dos Reis ; Sguissardi ,Valdemar (org.), 1997.
} 
As mudanças que ainda hoje estão acontecendo na educação requerem, segundo esses autores, a consideração de que elas acontecem no interior de um movimento que abrange a base produtiva ou, em outras palavras, na economia e na reorganização do Estado. Esse processo de reforma - tanto nos países centrais quanto em muitos países da América Latina, entre os quais se inclui o Brasil - está inserido no contexto:

- da passagem do regime de acumulação fordista para o da acumulação flexível, que implica a mundialização do capital, desemprego, financeirização etc;

- da diminuição do Estado, apresentada como privatização, que implica desconcentração e maior controle sobre todos os setores da economia e serviços, tais como saúde e educação;

- da mudança da idéia de conhecimento como bem coletivo para a de bem particular ou privado, o que resulta na mercantilização da educação e do saber;

- da campanha de qualificação do que é privado, incluindo a educação, e o desprestígio do que é público;

- da desconsideração de que o conhecimento científico (sobretudo na pesquisa básica) não consegue se realizar sem recursos públicos do Estado e que os interesses empresariais privados objetivam o lucro em última instância².

Considero pertinente desenvolver as questões apontadas acima. A crise e a reestruturação da educação superior e do Estado estão presentes em quase todos os países, seja na África, Ásia, América Latina ou nos chamados de primeiro mundo. São fenômenos relacionados às transformações econômicas no mundo, especialmente nos países europeus, onde a passagem do fordismo para um regime de acumulação flexível, com a conseqüente crise do Estado de Bem-estar

\footnotetext{
${ }^{2}$ Silva Jr., João dos Reis; Sguissardi, Valdemar, 1999: 19-20. O documento apresentado pelos alunos e professores da FAU-SJC ao Encontro Nacional sobre Ensino de Arquitetura em 1976 coincide com as argumentações acima. Esse documento será objeto adiante.
} 
Social, verifica-se com maior intensidade já desde os anos 1960 e $1970^{3}$.

As transformações ocorridas a partir dos anos 1960 são parte da dinâmica do sistema social em que vivemos. O contínuo movimento das esferas privadas e públicas no capitalismo é próprio desse modo de produção e nesse movimento inserem-se as necessárias transformações nos níveis político, cultural, social e econômico que revelam a expansão do capital, seja para outros lugares, seja para outros setores sociais. ${ }^{4}$ Esse movimento expressa-se hoje no campo educacional por suas reformas - em que se incluem as do ensino de arquitetura e urbanismo -, que foram apoiadas em última instância na mercantilização do ensino e do saber, o que significa que também o campo educacional está se tornando um espaço passível de ser organizado pelo processo de expansão do capital.

A análise do movimento de privatização da educação superior durante as décadas de 1960 a 1980 contribuirá para entender o contexto em que se desenvolveram as experiências de ensino de arquitetura e urbanismo selecionadas neste trabalho, e em especial a FAU-SJ C, objeto desta pesquisa, já que elas transcorreram no momento do crescimento do ensino privado.

\section{O ensino superior no Brasil nos anos 1960 a 1980}

Após a Reforma Universitária de 1968, durante o governo militar, já na época do Ato Institucional $n^{\circ} 5$, o ensino superior aparece em primeira instância visando consolidar o modelo social e econômico sustentado pelo autoritarismo do governo.

O desenvolvimento capitalista do país nessa época, com suas demandas econômicas e sociais, precisava ampliar o acesso ao ensino

${ }^{3}$ Silva Jr., João dos Reis; Sguissardi, Valdemar, 1999: 25 
do $3^{\circ}$ grau. Nesse contexto o regime visou transformar a educação em um elemento capaz de obter consenso e hegemonia; porém, contrariando esse discurso, priorizou o investimento nos setores mais ligados à acumulação direta do capital; para isso favoreceu a ampliação da privatização do ensino ${ }^{5}$.

Como visto anteriormente, a economia nas décadas de 1960 e 1970 estava em pleno processo de concentração e internacionalização do capital, necessitando de mão-de-obra qualificada para as exigências dessa fase, que incluía o consumo individual de bens duráveis. Parte dessa política foi a criação do BNH (Banco Nacional de Habitação), que funcionou de 1966 a 1985 com base no Fundo de Garantia por Tempo de Serviço (FGTS), correspondendo a $8 \%$ do salário depositado todo mês. Outro exemplo foi a Cecap (Caixa Estadual de Casas para o Povo), uma autarquia estadual paulista que em 1967 contratou Vilanova Artigas, Paulo Mendes da Rocha e Fábio Penteado para realizar 0 projeto de um conjunto habitacional em Guarulhos para 60 mil pessoas $^{6}$.

\section{As teorias políticas nos anos 1960 a 1970}

Nesse período, segundo Sousa Santos, o pensamento marxista renasceu com vigor e brilho, até o final dos anos 1970.

O eixo geográfico passou do capitalismo central para o capitalismo periférico. Destacam-se: a revolução chinesa, os movimentos de descolonização e a criação de novos países (muitos liderados por marxistas), a revolução cubana e a guerra do Vietnã; nos países capitalistas centrais da Europa e da América do Norte, o movimento estudantil do final dos anos 1960 e princípio dos anos 1970; e, nas

\footnotetext{
${ }^{4}$ Ibid.: $119-120$.

${ }^{5}$ Ibid.: 177-178.

${ }^{6}$ Este tema é tratado por Nabil Bonduki, 1998 e Arantes, P. F., 2002: 98; também informações fornecidas por Luiz Ackel em São Paulo, em 2006.
} 
democracias européias, o surgimento de partidos socialistas e comunistas fortes. Ainda na visão desse autor, as situações apontadas tinham por força que criar profundas revisões no pensamento marxista, o que se verifica também no Brasil.

Porém, pode-se dizer que, considerando o contexto no qual Marx desenvolveu suas teorias, o momento histórico em que viveu, obviamente não poderia prever, desde a sua realidade, a complexidade futura; sua contribuição importantíssima consistiu em ser 'matriz de matrizes' e não em deixar receitas fechadas. Sob essa ótica, a discussão teórica que transcorreu após ele em muitos casos pode ser vista como enriquecedora em vez de revisionista.

$\mathrm{Na}$ trilha do que afirma Boaventura de Sousa Santos, ao se referir a Foucault - que este só pôde desenvolver suas investigações sobre 0 pano de fundo do marxismo - , é possível estender essa idéia a outras reflexões do pensamento marxista.

A análise realizada por Sousa Santos sobre a genealogia do pensamento marxista destaca a influência da revolução chinesa, que caminhou rapidamente nos países periféricos e acabou por produzir uma divisão no movimento comunista mundial.

Boaventura de Sousa Santos sustenta que nesses anos na América Latina ocorria uma revisão profunda do marxismo, citando como exemplo a teoria da dependência elaborada por F. H. Cardoso em 1979. Essa idéia, porém, foi contestada por vários autores, entre eles Francisco de Oliveira.

Na Europa, destacava-se a descoberta dos Manuscritos Econômicofilosóficos de 1844 de Marx, até então desconhecidos. Nos anos 1960 a 1970, na Argentina, eles eram muito estudados e discutidos, assim como os Grundisse, de 1857-58. 
Nesses anos, B. de Sousa Santos diz que o marxismo assumiu nos países europeus duas orientações:

1. A escola de Frankfurt, conhecida como de teoria crítica, dirigida a partir de 1953 por Adorno e Horkheimer, a que se somou uma nova geração de teóricos críticos, entre eles Habermas.

2. O marxismo estruturalista francês, no qual se destacaram Althusser, Lévi-Strauss, M. Godelier e Lucien Goldmann.

Nesse período de grande criatividade teórica, produziram-se análises críticas:

- do Estado capitalista, por Habermas (1973), entre outros;

- do papel crescente da cultura e da ideologia: Marcuse (1970), Bourdieu (1970), Raymond Williams (1958, 1977) ${ }^{7}$.

Todos esses autores desenvolveram uma sociologia marxista de muitos matizes; segundo Boaventura de Sousa Santos, nessa época discutiam althusserianos e antialthusserianos, estruturalistas e fenomenologistas, mas as discussões fundamentais giravam em torno de:

1. Estratégias do movimento socialista.

2. Sua composição e sua viabilidade.

3. O papel da classe operária no movimento socialista.

4. A relevância dos novos atores sociais e novas agendas emancipatórias.

Os debates aconteciam, sobretudo no movimento estudantil, reforçando os argumentos de Sousa Santos. Quanto aos partidos comunistas europeus, o autor afirma que incompleta e tardiamente descobriram as virtualidades dos regimes democráticos.

Para muitos cientistas sociais, segundo B. de Sousa Santos, Marx se equivocara nas suas previsões sobre a evolução das sociedades capitalistas, e suas teorias só teriam alguma atualidade com revisões; nessa linha de pensamento, a atualidade é designada como pós-

\footnotetext{
${ }^{7}$ Sousa Santos, Boaventura de, 2003: 28.
} 
industrial por Touraine (1974), que vê a necessidade de repensar os atores e a ação social; aparecem revisões do marxismo, a partir da década de 1970, por exemplo, nos trabalhos de Habermas e Giddens. Na América Latina, porém, esse período não foi exatamente igual ao da Europa, como o descreve B. de Sousa Santos. Não é por acaso que Frei Betto $^{8}$, ao fazer uma sucinta biografia de Marighella, dedique tanto espaço à vida de Trotsky e faça um breve histórico comentando que a cisão provocada pelo movimento trotskysta em 1936 influenciou também o Partido Comunista Brasileiro, sobretudo em São Paulo, onde ganhou adeptos, ameaçando a unidade partidária.

Ainda na versão de Frei Betto, quase trinta anos depois da crise desencadeada no PCB pelos simpatizantes de Trotsky, vários acontecimentos nacionais e internacionais colaboraram para a vitória da guerrilha cubana, contrariando os PCs latino-americanos e o próprio partido comunista cubano ${ }^{9}$.

Na minha visão, na América Latina dos anos 1960 a 1970, e também no Brasil, o tema das alianças, o papel das burguesias nesses países, a validade ou não da etapa democrático-burguesa, as teorias de Marx, Lenin, Mao, Trotsky, assim como as de Giap, Debray ou Che Guevara, eram calorosa e acirradamente discutidas no âmbito universitário.

Esse período foi também sombriamente marcado por golpes militares latino-americanos, entre os quais se inclui o brasileiro. Parte das políticas que visavam garantir a expansão do capital tinham também sua expressão no plano educacional, cumprindo uma função preparatória das condições econômicas, culturais e sociais contemporâneas, definidas por Francisco de Oliveira como 0 'monstrengo social' em que nos transformamos.

\footnotetext{
${ }^{8}$ Frei Betto, 1982: 10.

${ }^{9}$ Alencar, Francisco e outros, 1979: 332.
} 
Os golpes militares não aconteceram exatamente no mesmo momento. No Brasil, o golpe militar se deu em 1964. Na Argentina, instalou-se em 1966, seguido por um período de democratização, com um novo golpe em 1976, após o do Chile e o do Uruguai.

Porém, no período 1960-70, não se pode deixar de destacar o ano de 1968, marco das lutas da juventude universitária no mundo e na América Latina, num clima de efervescência intelectual e de grandes debates $^{10}$.

O processo de conflito e reforma universitária nos anos próximos a 1968 pertence à história da universidade no mundo e na América Latina, e constitui o marco fora do qual não é possível entender as brechas democráticas abertas por algumas experiências de ensino de arquitetura, tais como as da FAU-SJ C (objeto de trabalho desta tese), da FAU-UnB (uma de suas influências diretas) e o Taller Total da FAUUNC (referência latino-americana), naquele período.

\section{8}

Nos anos 1960 as idéias contra a exploração, a desigualdade e a repressão política contribuíram para gestar uma força criativa, combativa e cheia de esperanças. Depois da crise dos mísseis em Cuba em 1962, grande parte do mundo ficou em alerta ante a possibilidade de um novo confronto mundial. Cuba, nesses anos, era o foco das esperanças de revolução para a América Latina e para a África ${ }^{11}$. Alguns aspectos caracterizavam a juventude desses anos; por um lado, tinha-se convertido em dominante das economias de mercado e, por outro, internacionalizou-se, compartilhando consumos e novos papéis

\footnotetext{
${ }^{10}$ Pronsato, Sylvia A. Dobry, 2005: 58.

11 Tarazona, Alvaro, 2006: 176.
} 
por meio da televisão, do rádio, das universidades e também do turismo internacional ${ }^{12}$.

Deve-se considerar também a mobilidade social, que possibilitou 0 acesso à universidade de grandes setores da classe média no mundo e em muitos países latino-americanos.

A geração dos anos 1960 tinha formulado um programa no qual se definia o ser revolucionário ao expressar sua visão de mundo e ideologia, questionar a realidade social, promover e difundir a ciência e a arte, lutar com as armas opondo à violência criminosa a violência justa, segundo Volpi no livro La imaginación y el poder ${ }^{13}$. Foi uma geração que se identificou com a esquerda, algumas vezes de forma intransigente e autoritária.

Houve nesses anos uma revolução cultural de magnitudes globais, permeada por um sentimento de reação ao imperialismo norteamericano que transcendia a esquerda, abrangendo intelectuais do mundo inteiro: a contracultura hippie, que, fundamentada na recusa aos valores tradicionais, falava de forma aberta sobre sexo; 0 questionamento das convenções sociais, expresso numa moda contestatória, por exemplo o cabelo comprido nos homens; o grande destaque de músicos como os Beatles, entre outros. Em tal clima, parte importante dessa geração discutia Marx, Mao, Trotsky ou Giap, a teoria do foco e Che Guevara, enquanto outra parte descobria as religiões orientais.

Mas 1968 foi, sobretudo, o ano do Maio Francês, que com sua palavra de ordem 'é proibido proibir' passou a ser o símbolo da luta contra todo autoritarismo e da tentativa de transformação da sociedade. Alguns meses antes do Maio Francês, iniciaram-se na Universidade de Nanterre as mobilizações lideradas por Daniel Cohn Bendit contra a guerra do Vietnã e exigindo como bandeira de luta a reforma educacional. As

${ }^{12}$ Hobsbawm, Eric, 1998: 327. 
autoridades fecharam a universidade e as organizações estudantis, em resposta, dirigiram-se à Sorbonne em busca de apoio, sendo detidos no Bairro Latino pela polícia. Em 10 de maio, um enfrentamento de cerca de quarenta horas deixava mais de cem detentos e feridos; mais tarde, 800 mil pessoas marcharam em apoio aos estudantes e poucos dias depois 10 milhões de operários, que representavam dois terços da força de trabalho francesa, declararam-se em greve. ${ }^{14}$ Criou-se uma Assembléia Nacional que pediu a cabeça de De Gaulle, e que a 30 de maio foi por ele dissolvida. Na análise de Touraine, “a crise revolucionária desencadeada, social, política e cultural, não concentrou a luta e também não criou instrumentos eficientes para a ação". ${ }^{15}$ Porém essa mobilização estava presente em quase todo o mundo. Assim, por exemplo, entre 1967 e 1968, na Inglaterra e na Itália houve passeatas contra a guerra do Vietnã e o sistema educacional, como também na Alemanha, onde as revoltas foram lideradas por Rudi Dutschke. Nos Estados Unidos, já no ano de 1964, surgiu na Universidade de Berkeley um movimento que, lutando por essas reivindicações, politizou os meios acadêmicos, influenciando muitos países, especialmente da América Latina. Na década de 1960, nos Estados Unidos, houve também grupos de jovens mobilizados pela luta contra o autoritarismo, a pobreza, a guerra; tinham força os grupos pela não violência, o poder negro, hippies, a nova esquerda e outros, unidos frente à repressão violenta do Estado. Na Europa Oriental ocorreram mobilizações e protestos estudantis e populares de outra natureza: a resistência aos governos 'marionetes' e a ocupação soviética, sobretudo na Polônia e na Tchecoslováquia, sufocada pela invasão de Praga em 1968. ${ }^{16}$

No México, em outubro de 1968, a Praça de Tlatelolco foi campo de batalha por horas, expressando a tensão entre o movimento estudantil

\footnotetext{
${ }^{13}$ Volpi, Jorge, 2001: 101-102.

${ }^{14}$ Dados de Volpi, Jorge, 2001: 156-158.

${ }^{15}$ Touraine in Tarazona, Alvaro A., 2006: 176.

${ }^{16}$ Dados de Volpi, Jorge, 2001: 154-166.
} 
e o governo, com o giro à direita do PRI (Partido Revolucionário Institucional). O saldo do conflito foi de cem feridos, 39 mortos, quase 500 detentos e a repressão de 'caça às bruxas' aos intelectuais e políticos que apoiaram esse movimento por uma reforma universitária democrática ${ }^{17}$ em um país onde o conservadorismo de seus dirigentes tinha-se aliado ao capital hegemônico norte-americano.

Na Colômbia, com uma realidade política diversa da de outros países latino-americanos, os estudantes das universidades públicas e privadas protestaram durante a década de 1960 contra a asfixia imposta pela Frente Nacional. Em aberto confronto contra o modelo político de exclusão, surgiram três grupos guerrilheiros (ELN e Farc em 1964 e EPL em 1967); a classe média emergente, em grande parte absorvida pela universidade, enfrentava o pacto de unificação da classe dominante. Nesse cenário, uma geração universitária que não encontrava os espaços de participação que exigia, explodiu politicamente. A tensão entre universidade e governo aumentou, quando, em 1966, Rockefeller, em viagem à Colômbia, visitou, junto com o presidente do país, prédios da Universidade Nacional construídos com o financiamento da Fundação Rockefeller. Em 1967 os professores fizeram críticas públicas ao comportamento abusivo força pública; e em 1968, também em maio, os estudantes reuniram-se às manifestações operárias numa grande passeata, solidarizando-se com eles quase $70 \%$ dos professores, chegando a 8 mil universitários e 2 mil operários. ${ }^{18}$ Segundo Tarazona, os estudantes demandavam a eliminação do Plano Básico para a educação superior, a diminuição do valor da matrícula, a elevação do nível acadêmico e a observância da autonomia universitária. Houve também a proposta da formação de uma frente camponesa-estudantil de solidariedade com países como Chile, Argentina, Venezuela, Espanha, França, Tchecoslováquia, nos quais o problema universitário tinha chegado a altos níveis de confronto. Em

\footnotetext{
${ }^{17}$ Tarazona, Alvaro A., 2006: 180.

${ }^{18}$ Ibid.: 181 .
} 
muitas cidades da Colômbia uniram-se a essa luta centrais operárias, populares e universitários, homenageando os estudantes que tinham sido mortos em confrontos, considerados mártires. Essas lutas, assim como em outros países, foram esquecidas nas décadas seguintes.

Na Argentina, o ano de 1966 foi de intensa mobilização estudantil por mais orçamento para as universidades. Com o golpe militar desse ano, os protestos tomaram uma dimensão massiva e, em meio a forte repressão, as universidades foram fechadas e perderam a autonomia. Mas em 1968 as palavras de ordem do Maio Francês juntaram-se às de 'unidade operário-estudantil'; em maio de 1969 eclodiu o Cordobazo, com características de insurreição popular. Nesses anos, organizam-se vários grupos guerrilheiros, como em muitos outros países da América Latina.

No Brasil, quatro anos após o golpe militar, cobraram-se, em 1968, as promessas de abertura democrática do então presidente Costa e Silva. Os estudantes realizaram manifestações em diversas capitais protestando contra a política educacional ${ }^{19}$ e o governo. No Rio de Janeiro, uma passeata de protesto reuniu 100 mil pessoas. 0 tiro que matou o estudante Edson Luís, nas ruas do Rio de J aneiro, indignou parte da sociedade. Artistas, intelectuais, estudantes promoveram atos públicos, passeatas, enfrentaram a polícia com barricadas improvisadas, incendiando viaturas, divulgando manifestos. Em São Paulo, as manifestações estudantis transformaram a rua Maria Antônia num campo de batalha e o prédio da Faculdade de Filosofia da USP foi ocupado diversas vezes pelos estudantes: o rosto de Che Guevara olhava das paredes os jovens que liam Lenin, Marx, entre outros, ao som dos Beatles.

Em determinadas categorias profissionais essas formas de enfrentamento ao regime ganhava maior visibilidade e portanto tornaram-se emblemáticas. 
Aumentava, cada vez mais, o número de falências de pequenas e médias empresas, assim como a concentração de renda consolidada na aliança entre o empresariado brasileiro e as multinacionais e a de terras nas mãos de poucos proprietários. A política econômica, cuja expressão era a contenção de salários, contribuía fortemente para o descontentamento popular, fazendo surgir as greves operárias, como as de Osasco, em São Paulo, e Contagem, em Minas. No Congresso, muitos parlamentares protestavam. Frente à crise, prevaleceu o 'endurecimento': o Congresso Nacional foi fechado e, a 13 de dezembro de 1968 , foi promulgado o Ato Institucional $n^{\circ} 5 .{ }^{20} \mathrm{~A}$ partir desse momento as cassações incluíram até líderes civis articuladores do golpe de 1964, como, por exemplo, Carlos Lacerda. Esse endurecimento era garantido, social e politicamente, pela coesão dos que se beneficiavam com o crescimento da produção.

Após o Al5, sucedeu-se uma "época de grande silêncio e muitas prisões nos meios estudantis, sindicais, artísticos e intelectuais. Há uma espécie de acordo entre o Estado e a burguesia: ela abria mão dos controles políticos tradicionais e de instrumentos como a liberdade de imprensa, o pluripartidarismo, o habeas corpus, e o Estado... mantendo a ordem a qualquer custo, assumia os interesses dos empresários como se fossem os de toda a Nação"21.

Foi nesse período conturbado e ao mesmo tempo pleno de esperanças, com uma relação de forças que se inclinava para o aprofundamento da repressão, que, com a intermediação do IAB, realizou-se o processo de reabertura da FAU-UnB - com a participação das lideranças estudantis que resistiam ao regime --, que influenciou de forma direta a proposta de criação do Instituto de Projeto e Comunicação (IPC) na FAU-SJ C. Num clima de tensão política, foi realizado o Fórum de 1968 na FAUUSP, palco de acirrado debate entre duas posições que interligavam o

\footnotetext{
${ }^{19}$ A intromissão dos Estados Unidos se expressa no acordo MEC-Usaid.

${ }^{20}$ Alencar, Francisco e outros, 1979: 324.
} 
nível político com o da arquitetura e urbanismo e seu ensino. Esse debate influenciará de forma direta o que se realizará na FAU-SJC durante seus cinco anos de existência, como também o produzido na FAU-Santos, já que a maioria dos professores provinha da USP.

No mesmo período, em maio de 1969, o Cordobazo foi o pano de fundo sob o qual se entreteceu a unidade operário-estudantil, dando impulso à luta dos estudantes de arquitetura e urbanismo da FAU-UNC para participar do concurso para estudantes da UIA 1969 com o tema Moradia de Interesse Social, proibido pelo diretor da faculdade. Essas ações contribuíram para a formulação e organização do Taller Total nessa faculdade na década de 1970. Inseridas no marco de $\mathbf{1 9 6 8 ,}$ traziam em seu bojo um tema que, na minha visão, foi o foco central do período: o debate sobre arquitetura e urbanismo e seu ensino.

\section{Novas questões para o debate no ensino de arquitetura}

A discussão sobre a formação do arquiteto tinha por base os diferentes modelos de ensino de arquitetura e urbanismo. Por isso, neste trabalho se realizará inicialmente um breve comentário a respeito, a partir do documento apresentado por professores e alunos da FAU-SJ C ao IX Congresso Brasileiro de Arquitetos, em 1976, com o título ‘PráticaInvestigação'.

"Modelos são abstrações da realidade", afirmavam os autores do documento citado, procurando estabelecer as características de um modelo organizativo de curso superior e selecionar critérios comparativos de diferentes cursos de arquitetura. Consideravam que um modelo de ensino pressupunha uma estrutura operacional na que se incluiriam:

1. "Forma regimental. 
2. Organização funcional e operativa - órgãos, conselhos, departamentos etc.

3. Estrutura curricular - distribuição de cargas horárias e conteúdos.

4. Conteúdo programático e metodológico". ${ }^{22}$

Ainda nesse documento destacam-se cinco modelos de ensino: Curso Seriado, Ateliê Central, Ateliê Interdepartamental (também chamado de Ateliê Integrado), Institutos de Arte e Unidades Interdepartamentais, cujas características serão analisadas no decorrer deste trabalho. Comprovando a afirmação dos autores contida no documento acima citado, os cursos superiores foram-se alterando com o passar do tempo devido às modificações das condicionantes históricas. Um curso superior é definido e delimitado pelos aspectos socioeconômicos, políticos e culturais que marcaram sua criação, de forma que cada mudança desses aspectos pode implicar alterações, em maior ou menor grau, do modelo do curso. Esses aspectos, para melhor entendimento dos cursos que serão analisados, podem provir:

- do meio universitário, que inclui fatores de ordem institucional e organizativos do ensino;

- do campo profissional, que abrange as necessidades sociais de produção ou de mercado de trabalho;

- da região de alcance, que envolve os fatores oriundos do meio circundante em que o curso funciona.

Porém, o esquema anterior não se esgota nesses fatores, que condicionam os cursos, já que a realidade deles é complexa.

Outro aspecto destacado no documento 'Prática-Investigação' citado acima foi o fato de o mercado ter assumido uma posição hegemônica em relação aos cursos de arquitetura nas décadas de 1950 e 1960 solicitava profissionais obedientes às normas de economia vigentes, ${ }^{23}$ no contexto de um programa de industrialização nacional, com o qual

\footnotetext{
${ }^{22}$ Fernandes, Ari e outros, 1976: 127.

23 Ibid.
} 
grandes setores de arquitetos e urbanistas assumiram um veemente compromisso. E, paralelamente, já na década de 1970, expandia-se a rede privada na educação superior. Isso mostra a importância de entender as políticas públicas voltadas para o ensino superior na época.

\section{O papel da reforma de 1968}

Segundo Silva Jr. e Sguissardi, o modelo econômico brasileiro foi alterado durante as décadas de 1950 e 1960, e emergiram grandes empresas públicas e privadas, além de multinacionais, que pretendiam mão-de-obra qualificada, 'diplomada' ao mesmo tempo que se colocavam obstáculos nas vias de ascensão social das classes médias. A reforma universitária de 1968, proposta pelo governo militar, via no ensino um caminho para essa ampliação e reprodução da classe média, considerada um mercado consumidor de grande valor no modelo de desenvolvimento aliado ao capital internacional. ${ }^{24}$

Nesse contexto, a expansão do ensino superior realizou-se aceleradamente na década de 1970, com o predomínio da iniciativa privada, fora dos grandes centros urbanos, de forma tal que, entre 1962 e 1973, passou-se de 100 mil a 800 mil o número de estudantes no ensino superior público e de 40 mil a 500 mil no ensino superior privado $^{25}$. Nessa situação incluíam-se as Faculdades de Arquitetura e Urbanismo, já que nesses anos foram inauguradas as FAUs Santos, SJ C, Mogi das Cruzes, entre outras. Em 1968, a FAU-USP instalou-se na Cidade Universitária com projeto de Vilanova Artigas, passando de 70 a 150 vagas por turma e de $2.000 \mathrm{~m}^{2}$ (na rua Maranhão) para $24.000 \mathrm{~m}^{226}$.

Possuir um diploma então significava muito no Brasil, já que os profissionais egressos de cursos superiores tinham cada vez mais a possibilidade de serem empregados de grandes firmas em vez de

\footnotetext{
${ }^{24}$ Silva Jr, J. dos Reis; Sguissardi, V., 1999: 178.

${ }^{25}$ Dados de Silva Jr. e Sguissardi, 1999: 178.
} 
atuarem como autônomos. O diploma passou a ser uma condição para uma melhor posição social.

Segundo Silva Jr. e Sguissardi, a falta de critérios na abertura de escolas superiores isoladas, em sua maioria privadas, que apresentavam nível inferior às das grandes universidades, dá-se sobretudo na década de 1970. Com apoio do Estado, essa década viu expandir-se rapidamente o ensino superior, do qual fazia parte 0 privado, mediante a entrada de empresários provenientes em sua maioria da educação de $1^{\circ}$ e $2^{\circ}$ graus. Como movimento empresarial que se introduzia no setor de prestação de serviços, isso assumiu grandes dimensões e constituiu uma das formas de acumulação e expansão de capital mais importantes. ${ }^{27}$

\section{A expansão do ensino superior privado}

Já no final do período nacional-desenvolvimentista verificavam-se tendências que culminaram, após o golpe militar de 1964, com a Reforma Universitária de 1968, que desempenhava papel central no modelo político. Isso se confirma nos relatórios da Eapes, do MECUsaid, do general Meira Matos, da CPI do Ensino Superior de 19671969 e do Grupo de Trabalho da Reforma Universitária, o que revela o prestígio e a importância que tinha a instituição universitária para 0 governo militar ${ }^{28}$.

A universidade com sua nova estrutura, na visão de Silva Jr. e de Sguissardi, buscava garantir a segurança do novo modelo de crescimento e formas de controle político-ideológico com maior grau de eficiência e racionalização.

\footnotetext{
${ }^{26}$ Dados de Albuquerque, R. Portugal, 2004.

${ }^{27}$ Silva Jr. e Sguissardi, V., 1999: 179. Associações e entidades tais como Confenem, Abruc, Anuc, ABS, entre outras, organizaram esse mercado com base em seus interesses privados e institucionais, como dizem os autores citados acima.

${ }^{28}$ Ibid.: 180.
} 
O esforço de privatização do ensino superior (submetido ao controle político e administrativo do Estado) não pode ser desligado da consolidação da economia brasileira internacionalizada no interior do capitalismo e no fortalecimento de um Estado autoritário.

Contratado pelo MEC ainda durante o governo de Kubitschek, em 1956, o assessor americano Rudolph Atcom foi o autor de uma proposta que, após várias modificações, em 1968 tomou a forma da Lei 5540, pela qual criavam-se as fundações universitárias. A lei definia sua autonomia e independência econômica, mas não a política, a jurídica ou a administrativa. As diversas modificações da proposta de Atcom residiam no fato de que o modelo inicial apresentado por ele atendia a uma das tendências do governo após 1964, a da desobrigação do Estado em relação ao ensino superior por meio da privatização, porém contrariava a tendência ao controle político da educação e à centralização do poder $^{29}$.

Dois decretos-lei ${ }^{30}$ (o $n^{\circ} 200$, de 1967, e $0 n^{\circ} 900$, de 1969) formavam a base legal da reforma administrativa do Estado, ao regulamentar 0 funcionamento e a criação de autarquias, fundações (incluindo as universitárias) e empresas estatais; assim, as fundações universitárias já nasciam sob um duplo movimento:

1. De recuperação do controle político-econômico sobre a universidade e

2. De diminuição da obrigação do Estado com a educação superior, incentivando a expansão dos Institutos de Ensino Superior (IES) privados.

Se por um lado, a partir do golpe de 1964, ampliou-se significativamente o ensino superior público no Brasil, sobretudo pelo aumento das universidades federais, por outro havia incentivo à expansão do ensino superior privado.

\footnotetext{
${ }^{29}$ Silva Jr. e Sguissardi, V., 1999: 182. Ver também Sofia Lerche Vieira, O (dis)curso da (re)forma universitária, Fortaleza, Editora UFC/PROED, 1962. Sobre autoritarismo e massificação no ensino superior, ver Arabela Campos Oliven, A paroquialização do ensino superior: classe média e sistema educacional no Brasil, Petrópolis, Vozes, 1990.
} 
Entre 1968 e 1971 foram criadas dezessete universidades públicas, entre as quais nove federais, seis estaduais e duas municipais, e entre 1968 e 1975 criaram-se dez universidades privadas.

Mas, na contramão da ampliação do ensino superior público, o Estado buscava a contenção de gastos por meio de duas formas de privatização:

- indireta, com a criação de fundações de direito público ou privado numa tentativa de desobrigar-se da manutenção do ensino superior, econômica e financeiramente, porém aumentando seu poder de intervenção;

- direta, pelo incentivo à abertura de instituições de ensino superior privadas de forma quase indiscriminada. ${ }^{31}$

Mas, ao mesmo tempo em que sua expansão se acelerava, a modernização do ensino superior incluía a pesquisa, que devia estar associada às demandas extra-universitárias, especialmente as que provinham do campo econômico, que passava por um processo acelerado de reestruturação. ${ }^{32}$ Destacava-se cada vez mais no ingresso a esse novo mercado de ensino a iniciativa privada não confessional, fenômeno que apareceu também em outros países latino-americanos. ${ }^{33}$ Concomitantemente procurava-se demonstrar que o Estado seria incapaz de atender à demanda crescente de acesso ao ensino superior. Para entender melhor o contexto em que se desenvolveu a FAU-SJ C, objeto de trabalho desta pesquisa, considero interessante aprofundar esse período.

O surgimento desse novo ensino privado revela inter-relações complexas:

\footnotetext{
${ }^{30}$ Silva Jr. e Sguissardi, V., 1999: 183.

${ }^{31}$ Ibid.

${ }^{32}$ Martins, C. B., 1988: 7-8.

${ }^{33}$ Ver: Arango, Diana Soto; Jardilino, José R., 2006. Também Sguissardi, V.; Silva Jr, J. dos Reis, 1997 (organizadores).
} 
- por um lado comparece o golpe militar de 1964 com suas mudanças no campo político e, em decorrência, na elaboração da política educacional, como afirmado anteriormente;

- com a derrubada do governo Goulart, o projeto liderado por Darcy Ribeiro de construção de uma universidade crítica da sociedade e de si mesma, na qual estavam comprometidas uma parte crescente dos docentes e estudantes do ensino superior, sofreria grandes modificações;

- porém, esse projeto de modernização do ensino, do qual fez parte a criação do ITA e da UnB, entre outras instituições de ensino, continuou integrando e orientando a política educacional no início do governo militar;

- houve mudança qualitativa, no sentido histórico, nos objetivos da modernização do ensino superior, já que a educação universitária perdera sua ligação com a idéia de criação de um capitalismo dito autônomo e nacional, passando a inserir-se, como fator instrumental, num projeto político econômico que visava consolidar um desenvolvimento associado aos centros hegemônicos do capitalismo ${ }^{34}$.

Simultaneamente à reformulação do ensino universitário, houve uma tentativa do governo de despolitização no nível acadêmico, que apareceu já nos primeiros pronunciamentos oficiais de seus representantes. Isso é revelado, por exemplo, no discurso do presidente Castelo Branco na Universidade do Ceará, quando poucos meses após o golpe de Estado manifestou-se contra a "perigosa tendência de infiltração de preocupações políticas na vida universitária, em especial no corpo discente" ${ }^{\prime 35}$.

Coerente com esse discurso, a ditadura militar reprimiu o movimento estudantil, combatendo e perseguindo a UNE, que passou à ilegalidade, criando simultaneamente o Diretório Nacional de Estudantes,

${ }^{34}$ Martins, C. B., 1988: 13-14. 
reconhecido pelo Estado. Porém, contraditoriamente, satisfazia algumas das reivindicações do movimento estudantil, despojando-as dos seus conteúdos ideológicos e políticos. Essas medidas e diretrizes contribuíram também, indiretamente, para a privatização do ensino superior, já que o clima de controle político-ideológico era favorável ao tipo de instituições universitárias privadas, de acordo com Silva Jr. e Sguissardi.

Outro aspecto importante que coadjuvou na privatização do ensino foi 0 aumento do número de aprovados que ficavam sem vagas nas universidades públicas, chamados de excedentes; de 30 mil no início da década passaram para 160 mil, exercendo pressão sobre o regime. ${ }^{36}$ Nesse processo, as propostas de Atcom, como dito anteriormente, tiveram importância central, já que, apoiado na idéia de universidadegrande empresa, construiu um organograma de sistema administrativo cujos controles eram internos - ideais para empresas privadas e adequados, na sua visão, à universidade brasileira. A idéia central da proposta era, por um lado, a desvinculação completa entre a execução e o planejamento da ação universitária e, por outro lado, o fato de que essas universidades deveriam estar livres da dependência econômicofinanceira do Estado, ao pressupor a participação da iniciativa privada e a anulação da gratuidade do ensino ${ }^{37}$.

Isso pode ser sintetizado no 'princípio da expansão com contenção de despesas', presente no acordo MEC-Usaid de 1968 e no relatório da Comissão Meira Matos, que salientavam a idéia da participação da iniciativa privada: esse princípio se revelava também no relatório do Grupo de Trabalho para Reforma Universitária e na promulgação da lei 5.540/68, que aprovava indiscriminadamente a criação de institutos de ensino superior privados ${ }^{38}$.

\footnotetext{
${ }^{35}$ Apud Silva Jr, J. dos Reis; Sguissardi, V., 1999: 185.

${ }^{36}$ Ibid.: 187.

${ }^{37}$ Silva Jr., J. dos Reis; Sguissardi, V., 1999: 187.

${ }^{38}$ Ibid.: 188-189.
} 
Em decorrência disso, iniciou-se nesses anos a privatização do ensino superior, processo no qual se inseriu a criação, em 1970, de três faculdades de arquitetura e urbanismo no estado de São Paulo, em Santos, Mogi das Cruzes e São José dos Campos.

\section{Década de 1980}

Mais de dez anos depois, o ensino superior privado sofreu uma reacomodação, devido, por um lado, a questões específicas do setor e, por outro, a questões socioeconômico-políticas gerais. ${ }^{39}$ Será interessante analisar esse período para entender o contexto em que surgiu, por exemplo, o Laboratório da Habitação da FAU-Belas Artes, ${ }^{40}$ diferente do contexto de criação das FAUs Santos e SJC e de reabertura da FAU-UnB.

Segundo Martins, ${ }^{41}$ quando as escolas isoladas tentaram atrair estudantes de setores mais modestos, setores da própria classe média que já tinham obtido seus diplomas e regularizado sua situação profissional, criticou o nível dos cursos oferecidos, mudando o discurso pelo da qualidade de ensino. Essa mudança levou também em consideração que os privilégios da classe média baseados na posse do diploma universitário poderiam ser ameaçados pela crescente quantidade de novos graduados. Surgiu assim, como uma das características da década, o discurso da avaliação da educação privada em que se levava em conta a qualidade de ensino ou o padrão acadêmico.

Mas havia outra característica relacionada à nova ordem mundial, que era a valorização do desenvolvimento da ciência, da técnica e a

\footnotetext{
${ }^{39}$ Na fase intermediária dessa re-acomodação, em 1976, foi fechada a FAU-SJC e encerrou-se a experiência dos ateliês integrados (interdepartamentais) na FAU-UnB. No contexto do endurecimento político com o golpe militar de 1976 na Argentina, terminou de forma violenta a experiência do Taller Total na FAU-UNC (Córdoba, Argentina).

${ }^{40}$ Não cabe aqui analisar a FAU-Belas Artes, que sendo parte de um processo interessante de ensino, foge ao alcance desta tese.
} 
formação de mão-de-obra qualificada relacionadas às novas bases produtivas ou de acumulação do capital. Isso contribuiu para que os empresários se aproximassem da educação em geral e da universitária em especial, com o intuito de que esta se subordinasse ao sistema produtivo ${ }^{42}$.

Ao finalizar a década de 1970 mudanças econômicas geraram um grave quadro inflacionário, agravando a situação de desemprego, o que contribuiu para uma revisão crítica sob a perspectiva qualitativa. Vários setores da sociedade pressionaram o governo, fazendo com que este se envolvesse no tema 'qualidade do ensino' em resposta às críticas da universidade pública, das associações de profissionais e segmentos da classe média inseguros com a perda de valor do título acadêmico. ${ }^{43}$

No período da redemocratização exigiram-se mudanças no ensino superior, vulnerável em decorrência da forma que tomou sua expansão. A orientação dos investimentos do Estado não se direcionava ao campo social, o que não favorecia o investimento do capital internacional no Brasil, cujo objetivo principal naquele momento era o de inserir-se na nova ordem mundial que emergia desde os anos $1970,{ }^{44}$ e isso não beneficiava o financiamento da estrutura de ensino universitário proposta.

\section{Os anos 1990}

No início dos anos 1990, a expansão universitária apresentava algumas características específicas: $82,2 \%$ dos estabelecimentos de ensino superior isolados concentravam-se na região Sul-Sudeste, sendo 36,3\% em São Paulo. Verificou-se uma redução, desde os anos 1980, no número de instituições isoladas, já que uma parte delas transformara-

\footnotetext{
${ }^{41}$ Martins, C. B., 1988: 111-113.

${ }^{42}$ Silva Jr., J. dos Reis; Sguissardi, V., 1999: 191, grifo nosso.

${ }^{43}$ Fonseca, Dirce M., 1994 apud Silva Jr e Sguissardi, 1999: 191-192.

${ }^{44}$ Silva Jr., J. dos Reis; Sguissardi, V., 1999: 192.
} 
se em universidades, e houve também expansão das universidades estaduais. Observava-se alta concentração de institutos de ensino superior, a maioria privados, no Sul-Sudeste, diferentemente do Norte, Nordeste e Centro-Oeste, em que são predominantemente públicos. ${ }^{45}$ Isso evidenciava a relação entre o poder aquisitivo da população e a categoria das instituições de ensino superior: nas regiões de baixa renda só o Estado supria as necessidades de educação superior.

As instituições de ensino superior, sobretudo as privadas, organizaramse em entidades e organizações com "fortes influências junto ao Legislativo, ao Conselho Federal de Educação, ao Conselho Nacional de Educação e eventualmente junto ao Poder Executivo"46.

A maioria dessas entidades e associações com base nas instituições universitárias centravam-se em São Paulo e eram condicionadas pelas demandas político-acadêmico-administrativas, influenciando com maior intensidade o setor privado de educação superior e sua produção ${ }^{47}$.

Com a Reforma de 1968, ficou claramente estipulada a tríplice função do ensino superior (particularmente das universidades): a pesquisa, 0 ensino e a extensão. Porém, segundo Moreira ${ }^{48}$, essas regras não foram muito respeitadas e não serviram de orientação para a expansão do ensino superior nas décadas de 1970 a 1980. Grande parte das instituições desse nível tinham origem em antigas escolas de propriedade familiar, muitas vezes de admissão, depois ensino primário e ginasial ${ }^{49}$, que passaram a atuar no ensino superior mantendo sua tradição de transmissão do conhecimento existente sem se preocupar com a pesquisa ou o trabalho de produção desse conhecimento.

\footnotetext{
${ }^{45}$ Ibid.: 193. Em 1980 existiam 882 instituições de ensino superior, 200 públicas e 682 privadas - dados baseados em estatísticas do MEC de 1994.

${ }^{46}$ Ibid.: 194.

${ }^{47}$ Ibid.

${ }^{48}$ Depoimento de Moreira, Roberto, pró-reitor de Pesquisa e Pós-graduação da Universidade Bandeirantes - Uniban, ex-professor da FE-USP, em entrevista concedida a Silva Jr. e Sguissardi, 1999: 194.

${ }^{49}$ No Chile, Argentina e outros países, esse fenômeno aparece da mesma forma.
} 
Nesse caso pode-se incluir a Fundação Valeparaibana de Ensino (FVE), à qual pertencia a FAU-SJ C, o que pode explicar, em parte, 0 enfrentamento entre a orientação do curso criado pelos professores, com o apoio dos estudantes, e a mantenedora, e que terminou com 0 fechamento da escola, durante as férias do início de 1976, com o aval do MEC.

Moreira relembra que a expansão do ensino superior nos anos 1960 a 1970 foi muito grande, em especial pela ampliação do ensino privado, porém a pesquisa foi uma exceção verificada em algumas instituições de ensino superior privadas confessionais, redundando na baixa qualidade em todos os níveis de ensino; os professores, de 20 mil em 1960, passaram a mais de 100 mil em 1979, para atender à demanda, e em decorrência, na visão de Moreira, era baixa a qualificação desse corpo docente. Apenas recém-graduados sem especialização e muito menos pós-graduação, sendo obrigados a ministrar aulas a grandes contingentes de alunos ${ }^{50}$.

O ensino privado de nível superior passou do atendimento de 25 a $30 \%$ dos estudantes nos anos 1960 para 70\% no fim dos anos 1990. Apesar de não atender às reais necessidades da sociedade brasileira, em 1960 tinha-se no ensino superior mais de 93 mil alunos; em meados da década de 1980 esse número fora multiplicado quinze vezes; e, em 1994, os dados do MEC falavam em mais de 1.600 mil alunos. ${ }^{51}$ Esses dados confirmam a afirmação de Silva Jr. e Sguissardi: até 1999, passados trinta anos da Reforma Universitária de 1968, o ensino superior privado tornara-se hegemônico no nível administrativo, determinando na maioria das vezes as políticas educacionais nas esferas do Executivo e do Legislativo em razão de sua solidez e organização.

\footnotetext{
${ }^{50}$ Na FAU-USP, como foram realizadas as titulações nesses anos (1970) é descrito por Miranda Magnoli em entrevista a Jonathas Magalhães P. da Silva, revista Paisagem e Ambiente n² 21 - FAU-USP, 2006: 13.

${ }^{51}$ Silva Jr. e Sguissardi, 1999: 180; também Fonseca, D. Mendes: 1992, onde é investigado o papel dos empresários do ensino privado na normatização do ensino superior.
} 
Já no setor do ensino superior público, as políticas revelam a proposta de um Estado enxuto, com poucos investimentos na década de 1990. Um artigo de Capelli e Marques, ${ }^{52}$ publicado no início de 1998, ilustra o dito acima, ao afirmar que "o governo determinou redução de $30 \%$ nas verbas do ensino superior, conforme reclamação do Conselho de Reitores das Universidades Brasileiras, que denuncia a atitude contrária à Lei de Diretrizes e Bases [...]. 0 presidente não se contenta em não investir um centavo na universidade pública; quer desestruturar a rede para justificar sua privatização, ainda que disfarçada em forma de parcerias com a iniciativa privada, que dita as regras conforme os valores que aplica".

\footnotetext{
${ }^{52}$ Ricardo Capelli, presidente da União Nacional de Estudantes, e Anderson Marques, presidente da União Estadual de Estudantes de São Paulo (Folha de São Paulo, 9 de fevereiro de 1998) apud Silva Jr. e Sguissardi, 1999: 198.
} 
Capítulo II

ALGUMAS EXPERIÊNCIAS DE ENSINO DE ARQUITETURA $\in$ URBANISMO: SÃO PAULO - BRASÍLIA - CÓRDOBA

\section{Algumas considerações}

A partir dos anos $1990^{1}$, o processo de mudanças no Brasil acentuou-se de forma acelerada, o que se revelou nas múltiplas reformas realizadas e que provocaram crescentes índices de concentração de renda, desemprego, embate social; essas mudanças apresentaram-se com o discurso da urgente e radical modernização do país para possibilitar a ampliação do fluxo de ingresso do capital financeiro internacional, aumento de produtividade e promoção da eqüidade social; sob essa ótica as políticas e ações públicas assumiram um novo paradigma no qual o Estado se reorganizou sob a lógica que reproduz e reflete a empresa capitalista.

No plano discursivo, segundo Silva Jr. e Sguissardi², nos anos 1980 as políticas públicas tiveram origem nas demandas sociais; já nos anos 1990 as políticas públicas em geral, e em especial as da esfera da educação, foram moldadas pelo que o Estado pode politicamente oferecer, organizado segundo a racionalidade da esfera privada e sua capacidade financeira.

\footnotetext{
${ }^{1}$ Silva Jr. e Sguissardi, 1999: 258.

2 Ibid.
} 


\section{Reorganização do capital no nível do ensino superior}

Para Francisco de Oliveira as políticas públicas para a área social foram também políticas econômicas; do paradigma da demanda social passou-se ao paradigma da oferta econômica, no interior de um movimento que foi ao mesmo tempo de expansão da esfera privada em prejuízo da esfera pública ${ }^{3}$. Isso se deveu, sobretudo, à crise do capitalismo iniciada nos anos 1970, deslocando capitais para esferas sociais não organizadas por ele.

No campo educacional a transformação de paradigma para as políticas públicas originou uma reforma profunda, ou seja, no plano da educação o novo paradigma conduziu à passagem da esfera educacional para a econômica com a mercantilização do ensino superior. Dessa forma, o capital reorganizou a educação superior visando à acumulação, porém ao mesmo tempo Ihe atribuiu outra dimensão simbólicocultural, impregnando todas as instituições de educação superior ${ }^{4}$.

Cabe aqui consignar as idéias de Saviani, a respeito da diferença de significado dos termos eqüidade e igualdade, já que a primeira vem substituindo a segunda no âmbito educacional:

"Parece, pois, claro que enquanto o conceito de igualdade está ancorado na raiz ético-ontológica da dignidade humana, o conceito de eqüidade parece fundar-se em razões utilitárias, próprias do neopragmatismo que vem sendo erigido como a filosofia dominante nestes tempos neoliberais" ${ }^{\prime \prime}$. Isso revela, segundo o autor, a transformação de conteúdo do novo contrato social que, mediante os processos de reformas, os Estados, inclusive 0 brasileiro, estão realizando, refletindo a substituição de

\footnotetext{
${ }^{3}$ Oliveira, Francisco de, em banca de defesa de doutorado de Jussara Maria Tavares Puglielli Santos, 1998. In Silva Jr.; Sguissardi, V., 1999: 258.

${ }^{4}$ Silva Jr. e Sguissardi, 1999: 258-259.

${ }^{5}$ Saviani, D., 1994. Conclusões na Sesión Plenaria ‘Calidad y eqüidad de la educación', realizada em maio de 1998, no Chile. In Silva Jr. e Sguissardi, 1999: 258-259.
} 
paradigmas: o de demanda pelo de oferta. Quando se fala em eqüidade com qualidade, fala-se em utilidade com eficiência, e seu critério de referência é o mercado, o que revela um tecnicismo diferente daquele das décadas de 1960 e 70, quando se acentuava a quantidade em prejuízo da qualidade. Já o tecnicismo dos anos 1990 revestiu-se do conceito de qualidade com o caráter de instrumento eficiente na lógica dos investimentos e otimização dos resultados ${ }^{6}$.

Na sua expansão, o capital promoveu mudanças econômicas, políticas e sociais, sobretudo por meio das reformas. Tais mudanças expressaramse no nível organizativo da educação superior, baseando-se em diagnósticos da sua crise, que partiam de idéias como:

- a excelência do privado e do mercado

- o saber como mercadoria

- a minimização do Estado

- a restrição da esfera pública

- o aumento da esfera privada

- a competitividade empresarial ${ }^{7}$.

O alerta de Buchbinder e Rajagopal ${ }^{8}$ ilustra essas novas situações, quando afirmam que as políticas de redução de déficit e a globalização do capital nas universidades, como parte de um processo que as articulava com as empresas, foram as forças principais que provocaram embates nos anos 1990 no ensino superior. Num clima de insuficiência de meios financeiros, essas articulações influenciaram o modelo das universidades, tornando-as mais condescendentes com as exigências da globalização e também com as estratégias de redução do orçamento para educação, o que tem afetado a construção do conhecimento e seu contexto social, o papel e a função dos docentes, a administração da universidade e, sobretudo, seus objetivos, levando, muitas vezes, a

\footnotetext{
${ }^{6}$ Ibid: $260-261$.

${ }^{7}$ Ibid.

${ }^{8}$ Buchbinder, H.; Rajagopal, P., 1995: 23 apud Silva Jr. e Sguissardi, 1999: 266.
} 


\section{transformar a produção do conhecimento em simples administração de dados e informações destinados a assessorar o mercado e a colocar a universidade como prestadora de serviços 9 .}

\section{Dois paradigmas para a universidade}

A análise realizada nas páginas anteriores sobre políticas públicas de ensino superior permite visualizar que as experiências dos cursos de arquitetura (ver Quadro 1) estavam incluídas na política de privatização de ensino que, no Brasil, fora iniciada pela ditadura militar de 1964 e que vem se manifestando até hoje.

Esse processo continha, de forma contraditória, o embate entre dois paradigmas: por um lado, o projeto de construção de uma universidade democrática, crítica de si mesma e da sociedade, com o qual estava comprometida uma parte expressiva dos docentes e estudantes, e por outro lado a idéia da universidadegrande empresa, onde o saber é considerado mercadoria. Nos anos 1970, outros paradigmas contidos nesse embate referiam-se ao pensamento de matriz racionalista, por um lado, e, por outro, à idéia que sobrevaloriza a sabedoria popular ${ }^{10}$. Esse embate teve particularidades em cada período e em cada lugar onde se realizaram os cursos de arquitetura que este trabalho está enfocando e que serão analisados com maior profundidade nos próximos capítulos.

Outro aspecto desenvolvido nas páginas anteriores, que se refere à discussão e teorização da idéia de subdesenvolvimento - seja como a dualidade atrasado versus moderno, seja como duas polaridades que intervêm dialeticamente num todo, tal qual é o desenvolvimento

\footnotetext{
${ }^{9}$ Silva Jr. e Sguissardi esclarecem o fato de que, atuando como prestadoras de serviço, ficam as universidades liberadas das exigências que se colocam a essas instituições. Ibid: 269.

${ }^{10}$ Oliveira, Francisco, 2007: Banca de Qualificação da autora.
} 
desigual e combinado do capitalismo no Brasil e na América Latina -, interessa nesta pesquisa por vários motivos:

1. Esse é um dos pontos de divisão da esquerda mundial e sobretudo a latino-americana, atuando como um divisor de águas que definiu a estratégia de cada grupo político frente às burguesias nacionais. A análise em profundidade desse tema foge ao alcance desta pesquisa, porém interessa enquanto contexto para entender a visão de mundo que os professores e estudantes participantes dessas experiências imprimiram às suas visões de arquitetura e de ensino.

2. Em particular no Brasil, mas também nos outros países latinoamericanos, essa teorização definiu as posições dos diferentes setores de esquerda frente ao desenvolvimentismo e aos golpes militares. Isso se traduziu, no campo específico da arquitetura, na ilusão de que existiria no Brasil uma burguesia nacional interessada em desenvolver a industrialização da construção. Essa idéia permeou tanto o desenho das propostas arquitetônicas, casadas com um programa de industrialização nacional, como algumas propostas de ensino, que serão apresentadas nos próximos capítulos.

No plano da arquitetura, havia setores que, ao deixar de acreditar na possibilidade imediata de industrialização da construção, pesquisaram sistemas de construção a partir das técnicas populares, que poderiam ser racionalizadas e aplicadas em larga escala, tais como os préfabricados in-situ.

\section{Algumas experiências de ensino de arquitetura e urbanismo São Paulo/ Brasília/ Córdoba - anos próximos a 1960}

Essas discussões tiveram relação direta com escolhas e debates de arquitetura e seu ensino, expressados tanto nas FAUs USP e UnB (de São Paulo e Brasília) quanto na FAU-UNC (de Córdoba, Argentina). As 
duas primeiras constituíram uma influência direta para a FAU-S) C (de São J osé dos Campos), objeto de trabalho desta pesquisa. A terceira constituiu-se uma referência latino-americana, em especial para a FAUUnB, a partir de 1971.

O foco desta pesquisa centra-se na FAU-SJ C por ter vivenciado no decorrer de sua existência um laboratório de ensino, com visão crítica e transformadora. Essa faculdade foi, talvez, onde o debate, por vezes acirrado, pôde ser mais aprofundado, no contexto da privatização do ensino no Brasil.

Considero necessário neste capítulo iniciar um breve histórico dos momentos vistos como relevantes no ensino de arquitetura e urbanismo, fazendo um recorte em São Paulo, Brasília e também Córdoba, Argentina, num período que vai de 1962 a 1985.

Os anos próximos a 1960 foram férteis em debates sobre o ensino de arquitetura em toda a América Latina, no contexto do desenvolvimentismo e da atuação da Cepal, como visto anteriormente. Isso se verifica pela realização, entre outros, do X Congreso Panamericano de Arquitectos, em Buenos Aires, no ano de 1960 e da II Conferencia de Escuelas y Facultades Latinoamericanas de Arquitectura, no México, em 1961. Considero interessante destacar a resolução $n^{\circ} 4$ da Comissão 1 do Congresso citado acima, que afirmava:

- “Uma condição básica no ensino de Arquitetura na América Latina é a incorporação de um conteúdo social na sua orientação docente e pedagógica, ou seja, nos seus planos de estudo e métodos de trabalho.

- O arquiteto formado deve ser orientado como um criador e um técnico a serviço da comunidade e de sua organização institucional, capacitado não só a resolver determinados problemas de sua especialidade, como também a planejar em escala massiva os mecanismos técnicos e administrativos necessários". 
Como conseqüência, o X Congresso indicava:

1. "Que os centros de estudo de arquitetura no continente enfatizem o conteúdo social do ensino oferecido, em especial nas seguintes disposições:

- Ensino de Economia e Sociologia orientadas como disciplinas que devem integrar-se à criação arquitetônica.

- Ensino da História da Arquitetura com um sentido de orientação socio-filosófico.

- Solução de projetos vinculados à realidade nacional.

2. Que se introduzam e desenvolvam as técnicas de Administração no nível superior como complemento dos estudos de Planejamento"11.

\section{FAU-UNC}

Em 1963, na FAU-UNC de Córdoba, Argentina, formou-se a Comissão Assessora do Plano de Estudos. Os estudantes expressavam suas propostas através do Centro de Estudantes de Arquitetura e Urbanismo (CEAU) e dos agrupamentos que dele participavam, e, entre elas, podese citar 'Objetivos de un plan de estudios - análisis e punto de vista'. Cabe aqui registrar a bibliografia dessa proposta, que evidencia as inter-relações existentes na época, no âmbito nacional e latinoamericano, no debate de ensino de arquitetura e urbanismo, com ênfase nas idéias desenvolvimentistas.

“ARMENGOL, Miguel Casa e outros. 'La formacion del nuevo arquitecto'. Universidade de Zulia, Venezuela.

Centro de Estudios del Desarrollo. 'Informe final', maio de 1960. Universidade Central da Venezuela.

\footnotetext{
${ }^{11}$ Documento ARA-CEAU (Centro de Estudantes de Arquitetura e Urbanismo), 1963: 15.
} 
Centro de Estudiantes de Arquitectura de Tucumán (Argentina). 'Plan de estudios'.

II Conferencia de Escuelas e Facultades Latinoamericanas de Arquitectura. México, outubro de 1961.

Acta de Bogotá (Colômbia), 1960. 'Orientación social y económica para el desarrollo en América Latina'. Secretaria Coordinadora del Instituto de Arquitectura UNL, Rosario, 1960.

Unión Panamericana. 'El problema de la vivienda en América Latina'

X Congreso Panamericano de Arquitectos, Buenos Aires, $1960^{\prime 12}$.

Nos anos 1960, na FAU da Universidade Nacional de Córdoba, assistiase a verdadeiras disputas entre as ditas disciplinas 'práticas' ou 'de ateliê' (Composição Arquitetônica, Plástica, que incluía Paisagismo e Desenho Industrial e Urbanismo) e as 'teóricas', que se orientavam pelo sistema tradicional de aulas 'magistrais' complementadas por trabalhos práticos. Na disputa pela hegemonia, as duas concepções de ensino alternavam-se. ${ }^{13}$ Nesse período buscaram-se alternativas para resolver essa diferença de critérios no ensino de arquitetura e urbanismo, visando um curso integrado. Para isso realizaram-se tentativas que, ao serem postas em prática, possibilitaram sua avaliação e reformulação, caracterizando-se esses anos pela variedade de novos currículos. Em 1963 surgiram as propostas de: Ateliês Verticais-Horizontais, no nível de graduação, do 1으 ao 5a ano (tendo como eixo central a disciplina Composição Arquitetônica), e, no nível de pós-graduação, um Instituto de Planejamento, que contaria com a colaboração de profissionais de outras especialidades e que atuaria interligado com a graduação.

\footnotetext{
12 Ibid: 02.

${ }^{13}$ Fontán, Juan Carlos; Novillo Corvalán, Marcelo, 1971: 02.
} 
O Instituto de Planejamento visaria:

- A atualização dos estudos necessários para resolver o problema da habitação.

- A orientação e o controle dos núcleos humanos próximos.

Esse instituto desenvolveria:

1. Estudo dos problemas pontuados, com a colaboração mencionada.

2. Recompilação, ordenação e elaboração dos dados coletados.

3. Transmissão das conclusões às cátedras, em forma de Plano de Trabalho.

4. A faculdade deveria fazer conhecer os projetos elaborados aos organismos estaduais ou privados que pudessem se interessar ${ }^{14}$.

Em 1965, após vários debates e encontros internos (fóruns) de professores e estudantes, definiram-se quatro áreas: histórico-cultural, tecnológico-estrutural, plástica e Composição Arquitetônica. Definidas essas áreas, tentaram-se vários tipos de coordenação, vertical e horizontalmente. No primeiro caso obteve-se relativo sucesso; já a tentativa de coordenação horizontal entre essas áreas não teve êxito. ${ }^{15}$

A III Clefa (Conferência Latino-americana de Escolas e Faculdades de Arquitetura), realizada em 1964 na cidade de Alta Gracia, província de Córdoba, Argentina, marcou a FAU-UNC. Nela reuniram-se arquitetos e estudantes latino-americanos. As decisões adotadas e a resolução final foram referências para o Taller Tota ${ }^{16}$. Participaram, entre outras, as faculdades de Rosário, Nordeste, Tucumán, Montevideo (Uruguai), Lima (Peru) e Córdoba com "múltiplas argumentações e debates sobre questões pedagógicas e políticas, tentando superar as propostas conservadoras presentes na Conferência"17. Após a Clefa, em muitas

\footnotetext{
${ }^{14}$ Documento ARA-CEAU, 1963: 30.

${ }^{15}$ Fontán, Juan Carlos; Novillo Corvalán, Marcelo, 1971: 02.

${ }^{16}$ Elkin, Benjamim, 2000: 32.

${ }^{17}$ Ibid.
} 
das FAUs da América Latina sucederam-se os fóruns de debates de estudantes e docentes.

\section{FAU-UnB}

O ano de 1962 pode ser lembrado no Brasil ${ }^{18}$ por três acontecimentos relevantes: a inauguração da UnB (Universidade de Brasília), com a implantação de três cursos (de caráter transitório) chamados de cursostroncos, considerados o embrião da universidade (direito, economia e administração; arquitetura e urbanismo; letras brasileiras e jornalismo), e as reformas na FAU-USP, em São Paulo, e na FAU-UFRGS, no Rio Grande do Sul ${ }^{19}$.

Em seu livro Universidade para quê?, Darcy Ribeiro conta que se discutia sobre a conveniência ou não da presença de operários e estudantes na nova capital; a ausência deles era defendida, entre outros, pelo engenheiro Israel Pinheiro; e Kubitschek duvidava da conveniência de instaurar em Brasília uma universidade pública ou privada $^{20}$.

É preciso lembrar que já estava presente nesse momento o embate entre a idéia do saber como bem coletivo, defendida por Darcy Ribeiro, Anísio Teixeira, Oscar Niemeyer, Artigas, Edgard Graeff, entre outros, e a do saber como bem particular ou privado, que leva à idéia de mercantilização da educação e do saber, claramente refletida na contratação do assessor norte-americano Rudolph Atcom em 1956, durante o governo Kubitschek, em plena vigência do desenvolvimentismo. As sucessivas propostas de Atcom foram parte do processo que finalizou com a reforma de ensino de 1968. Isso poderia explicar a organização da UnB através da Fundação Universidade de

\footnotetext{
${ }^{18}$ Importante lembrar que o MEC em 1962 desenvolvia o Programa Nacional de Alfabetização, inspirado no método de Paulo Freira. As idéias desse educador influenciaram fortemente o Taller Total de Arquitetura em Córdoba, Argentina, nos anos 1970, e Rodrigo Lefèvre, referência marcante nas novas propostas de ensino em São Paulo.

${ }^{19}$ Pereira, Miguel, 2005.

${ }^{20}$ Ver Ribeiro, Darcy, 1986.
} 
Brasília, visto que as fundações só serão regulamentadas em 1967 e 1969, nascendo com um duplo movimento: por um lado, o da recuperação do controle político-econômico sobre a universidade, e, por outro, o da desobrigação do Estado com o ensino superior, exceção feita para o ITA e a UnB. Em outras palavras, contenção no âmbito do ensino superior público e incentivo no do privado. Por isso, na minha visão a UnB nasceu no seio do embate dos dois paradigmas citados, num momento em que a relação de forças contribuía para o tipo de universidade pela que batalharam, entre outros, Anísio Teixeira e também Darcy Ribeiro, que revela esse embate no livro citado: “Nós, que lutamos para ver surgir a Universidade de Brasília, tal como foi concebida e afinal consagrada na lei, sempre a pensamos como a casa da consciência crítica em que o Brasil se explicaria e encontraria saída para seus descaminhos"21. 0 autor destaca também a idéia de uma universidade que, no plano cultural, fosse tão inovadora quanto o era Brasília do ponto de vista arquitetônico e urbanístico.

Em 1962, durante a primeira reunião do conselho que dirigia a Fundação Universidade de Brasília (FUB), Darcy Ribeiro foi eleito presidente desse conselho e reitor da $\mathrm{UnB}^{22}$.

No mesmo ano foi criado na UnB o Instituto Central de Artes, associado à Faculdade de Arquitetura e Urbanismo, o ICA-FAU ${ }^{23}$, do qual participavam, entre outros, Mayumi W. e Sergio Souza Lima, ${ }^{24}$ em início de suas carreiras docentes, Edgard Graeff e J oão da Gama Filgueiras Lima. Nessa época, a maioria das "FAUs vivia sob a tutela dos cursos de engenharia a partir dos quais foram criadas. A exceção do período foi Brasília, onde o CAU (curso e não faculdade) pertencia ao Instituto Central de Artes (ICA). Ali são postas em prática, pela primeira vez em 1962, as propostas do Ateliê Integrado que os debates dos arquitetos

\footnotetext{
${ }^{21}$ Ibid.

${ }^{22}$ Dados de Albuquerque, Roberto Portugal, 2004: 55.

23 Ibid.

${ }^{24}$ Curriculum vitae apud Lima, Mayumi W. Souza, 1995: 245.
} 
vinham sugerindo (em tese) desde a segunda metade dos anos 50". ${ }^{25}$ O ICA-FAU da UnB será uma referência importantíssima tanto na criação da IPC-FAU de São J osé dos Campos em 1970, como na reestruturação para a reabertura da FAU-UnB em 1968, após o fechamento por ocasião do golpe militar ${ }^{26}$ em 1964.

Segundo os professores e estudantes da FAU-SJ C que apresentaram o documento 'Prática-Investigação' ao IX Congresso Brasileiro de Arquitetos, os institutos de Arte eram um modelo tipicamente universitário, que "estabelece um ciclo básico - ou $1^{\circ}$ ciclo - de dois anos, onde são agrupadas as disciplinas afins de diversos cursos. $02^{\circ}$ ciclo, ou ciclo profissional, seria específico para cada curso [...] 0 exemplo típico de modelo de instituto seria a UnB (Universidade Nacional de Brasília), apesar das inúmeras modificações por que passou em sucessivas crises desde sua implantação. No modelo de institutos são preservadas a autonomia das Faculdades ( $2^{\circ}$ ciclo), a departamentalização e a seqüência curricular. Verifica-se uma ampliação do horizonte de conhecimento dos estudantes - no ciclo básico - pelo contato com outras áreas afetas à arquitetura, comunicação e artes em geral"27. A escola Bauhaus pode também incluir-se nesse modelo. "Este modelo universitário estará sempre associado a um dos modelos de curso específico. É possível ainda, no modelo de institutos, o desdobramento de uma determinada faculdade em mais cursos, visando a formar profissionais mais especializados. ${ }^{28}$ Considero interessante, devido à importância do papel que viria a ter Mayumi Souza Lima na FAU de São J osé dos Campos, registrar sua atuação na ICA-FAU da UnB como docente entre os anos 1963 e 1965, em que foi co-responsável pelo curso de Física Aplicada às Construções, com J oão da Gama Filgueiras Lima, durante o $1^{\circ}$ semestre de 1963;

\footnotetext{
${ }^{25}$ Fernandes, Ari; entrevista concedida à autora em novembro de 2006.

${ }^{26}$ Segundo depoimento do arquiteto Paulo Bastos em entrevista concedida à autora em outubro de 2006.

${ }^{27}$ Fernandes, Ari e outros, 1976: 128.

28 Ibid.
} 
nesse mesmo semestre realizou um estágio docente em Teoria da Arquitetura com Edgard Graeff; foi co-responsável pelo curso de Edificações-Técnicas I e II, com o engenheiro Eustáquio de Toledo, durante $01^{\circ}$ e o $2^{\circ}$ semestre de 1964; no mesmo ano, no $1^{\circ}$ semestre, foi auxiliar do curso de Iluminação-Pós-graduação, com o arquiteto João da Gama Filgueiras Lima; em 1965 passou a ser Assistente da Universidade de Brasília, após defender, nessa universidade, no mesmo ano, a dissertação de mestrado 'Aspectos da habitação urbana'. Desenvolveu, paralelamente à atividade docente, trabalhos para a Ceplan/ UnB com Oscar Niemeyer, Edgard Graeff e J oão da Gama Filgueiras Lima.

\section{FAU-USP}

Para entender o significado da reforma de ensino de 1962 na FAU-USP, considero necessário descrever o processo anterior a essa reforma.

Como dito anteriormente, os primeiros cursos de arquitetura foram organizados pelo sistema de justaposição de disciplinas artísticas e técnicas; as primeiras provinham dos Liceus e Cursos de Belas Artes, que formavam artistas, decoradores e mestres de edificações; já as disciplinas técnicas provinham dos Cursos Politécnicos, que formavam engenheiros-arquitetos. Esses primeiros cursos $^{29}$ formavam profissionais para um mercado embrionário e de contornos ainda difusos, que exigia arquitetos de 'bom gosto e estilo' para realizar projetos de edifícios de alta elaboração estética e modernas residências ${ }^{30}$.

\footnotetext{
${ }^{29}$ Interessa registrar que esses cursos, como dito no capítulo 1, iniciam-se após a Segunda Guerra Mundial (Rio de Janeiro, em 1946, São Paulo, 1947 e 1948 etc.) e estão também inseridos no debate internacional, como revela o fato de que um dos temas do CIAM IV, realizado em 1947, foi a discussão sobre a Reforma da Educação.

${ }^{30}$ Sobre esse tema, entre outros: Fernandes, Ari e outros, 1976: 126; também Pereira, Miguel Alves, 2005: 111 e Albuquerque, R. Portugal, 2004: 41.
} 
Mas foi a construção do Parque do Ibirapuera entre 1952-56 - com projeto dos edifícios da equipe coordenada por Oscar Niemeyer e composta de Helio Uchôa Cavalcanti, Eduardo Kneese de Melo e Zenon Lotufo, com participação dos então jovens arquitetos Carlos Lemos e Gauss Estelita e projeto paisagístico de Otavio Teixeira Mendes ${ }^{31}$ - e o Concurso do Plano Piloto de Brasília, em 1956, que constituíram o marco em que se iniciou a fase de afirmação profissional do arquiteto, “baseada na formação de equipes de projeto e na integração e participação dos profissionais no grande projeto da sociedade brasileira". ${ }^{32}$ No contexto do desenvolvimentismo, que incluía a intensificação do sentimento nacionalista, ganhou destaque a idéia de uma arquitetura transformadora da sociedade e o projeto passou a ser considerado instrumento dessa transformação; nesse período os cursos de arquitetura modificaram-se com o objetivo de formar arquitetos capacitados $^{33}$ a responder aos novos campos de atuação que surgiam, no qual se incluiu o processo da reforma da FAU-USP, em 1962.

“Ao mesmo tempo, a universidade brasileira atravessa um período de discussões profundas sobre seu papel histórico, seu compromisso com uma realidade nacional em transformação. Esta fase é marcada, nos cursos de arquitetura, por uma postura muito mais voltada às perspectivas do campo profissional, do que às proposições transformadoras da Universidade" ${ }^{\prime 34}$.

A FAU-USP criou, em $1954^{35}$, a Comissão de Ensino, com a função de órgão consultivo, iniciando a modificação curricular; em 1955, regulamentou suas atividades, sete anos após sua separação da Escola Politécnica. Em fevereiro de 1957, publicou o programa proposto com os conteúdos de cada cadeira, sendo 24 no total, com só quatro

\footnotetext{
${ }^{31} \mathrm{O}$ embate sobre a autoria do projeto paisagístico e a atuação pontual de Burle Marx no Parque do Ibirapuera é descrito por Mariano, Cassia, 2005: 95-123.

${ }^{32}$ Fernandes, Ari e outros, 1976: 126.

33 Ibid.

${ }^{34}$ Fernandes, Ari e outros, 1976: 126.

35 Dados de Albuquerque, Roberto Portugal, 2004: 6, 13-14.
} 
professores engenheiros; em 1955 eram 29 cadeiras, correspondendo 24 ao curso de arquitetura e seis ao curso de urbanismo ${ }^{36}$.

As cátedras, verdadeiros feudos murados, defendiam na área do conhecimento rígidos limites, e os catedráticos nomeavam seus assistentes e auxiliares de ensino ${ }^{37}$.

Ainda em 1957 formou-se uma comissão de professores-arquitetos na FAU-USP com o intuito de analisar e propor reformas visando 0 aperfeiçoamento do ensino ${ }^{38}$. Participaram Rino Levi, Vilanova Artigas, Abelardo de Souza, Helio Duarte e Zenon Lotufo, que propuseram a modificação da seriação das cadeiras, com o objetivo de adequar o curso à legislação federal vigente, concentrando nos primeiros anos as “cadeiras técnicas, de modo a dar ao aluno, já no início do terceiro ano, a base técnica necessária para enfrentar os trabalhos de projeto" ${ }^{39}$.

A proposta de 1957 dava ênfase à Composição porque esta deveria ter a importância que tem no exercício da profissão; organizava e reunia as cadeiras existentes; agrupava as disciplinas pela sua natureza e função na capacitação do arquiteto em:

- formação técnica

- formação científica

- cultura

- ateliê $^{40}$.

Essa proposta não se efetivou, mas foi base para a reforma de 1962 em conjunto com o Primeiro Encontro de Estudantes e Arquitetos ${ }^{41}$. Outros

\footnotetext{
${ }^{36}$ Pela lei 3.233/55, o curso de urbanismo só poderia ser acessível aos portadores de diploma de arquitetura ou engenharia civil (ibid: 01).

${ }^{37}$ Ver Albuquerque, Roberto Portugal, 2004.

${ }^{38}$ Ibid: 52.

${ }^{39}$ Millan, Carlos, 1962.

40 Ibid.

$411^{\circ}$ Seminário Nacional do Ensino de Arquitetura e Urbanismo, organizado pelo BNAU

(Bureau Nacional de Estudantes de Arquitetura e Urbanismo) e o IAB (Instituto de Arquitetos do Brasil) em 1958, que pela primeira vez analisa em âmbito nacional a relação ensinoprofissão.
} 
encontros se sucederam no Brasil, no mesmo período em que aconteciam Encontros Latino-americanos e também mundiais ${ }^{42}$.

Nesses encontros defendia-se, entre outras coisas, o ensino desenvolvido em ateliê, com a integração das disciplinas técnicas nos processos de elaboração dos trabalhos de composição, considerada como eixo do curso e vinculada à realidade profissional. Postulava-se um ensino de arquitetura com maior atualização em sua formulação geral e adequado aos fins sociais. Considerava-se conveniente que a formação técnica se concentrasse nos primeiros anos do curso, ou seja, que a seriação das disciplinas atendesse de forma decrescente os conteúdos técnicos e de forma crescente os culturais ${ }^{43}$, mantendo como eixo constante as composições arquitetônicas (atuais projetos); também criticava-se os vestibulares por haver predomínio de matemática, ficando os aspectos culturais e artísticos quase ausentes ${ }^{44}$.

Por ocasião da escolha do novo diretor da FAU-USP, em 1961, os professores arquitetos encaminharam ao reitor um memorial destacando a urgente necessidade da reformulação do ensino, com o objetivo de superar uma estrutura que deixava um grande abismo entre a escola e a profissão. Ao ser nomeado o novo diretor, dr. Lourival Gomes Machado (cuja origem era a Faculdade de Filosofia, Ciências e Letras da USP), os professores foram solicitados a elaborar o novo currículo de arquitetura. Foram organizados vários grupos de trabalho e depois uma comissão composta pelos professores arquitetos Carlos Millan, J on Maitrejean, Giancarlo Gasperini e Lúcio Grinover, encarregada, em reunião de professores, de elaborar um estudo preliminar para a estrutura do Ateliế $\hat{e}^{45}$.

\footnotetext{
${ }^{42}$ Entre outros pode-se citar, como dito anteriormente, a II Conferencia de Escuelas e Facultades Latinoamericanas de Arquitectura, realizada no México em 1961, e o X Congresso Panamericano de Arquitetos, realizado em Buenos Aires em 1960.

${ }^{43}$ Segundo encontro sobre Ensino de Arquitetura, Porto Alegre, 1960, ‘Conclusões’. Essas diretrizes já eram tradicionais nas faculdades uruguaias e chilenas, segundo Pereira, Miguel, 2005: 113.

${ }^{44}$ Albuquerque, R. Portugal, 2004: 56.

${ }^{45}$ Millan, Carlos, 1962: 05, revista Sinopses, 1993.
} 
Segundo Albuquerque, o documento mais marcante da proposta foi 0 relatório apresentado por Carlos Millan, coordenador do grupo de estudo do Ateliê, com o título de 'O ateliê na formação do arquiteto', em janeiro de 1962. Nele se reforça a idéia da "necessidade de encarar a arquitetura e o urbanismo como um todo. Uma das falhas mais graves da estrutura de ensino que rejeitamos reside precisamente na dissociação, que subtrai a arquitetura do seu contexto natural e imprescindível, fora do qual ela não se explica e não pode ser compreendida" 46 .

As propostas de reforma de 1962, tanto da FAU-USP quanto a da FAUUFRGS, do mesmo ano, inseriam-se em estruturas conservadoras, porém tentavam, no interior das faculdades, romper barreiras ${ }^{47}$.

Foram criados e organizados quatro departamentos:

- Composição

- Histórico-crítico

- Ciências Aplicadas

- Disciplinas Técnicas

$E$, além desses, um Museu, que funcionava como órgão coordenador das atividades curriculares e complementares de ensino de arquitetura, com o objetivo de incentivar e estimular o interesse por áreas afins, tais como cenografia, fotografia, artes gráficas, maquetaria etc. ${ }^{48}$ Porém, no modelo de Ateliê Central, exceção feita ao Departamento de Projeto (ou Composição), as disciplinas dos outros Departamentos continuavam seguindo a seriação inicial, isoladas, tornando-se o Ateliê um meio de afirmação dos arquitetos como forma de controle do processo de ensino ${ }^{49}$.

O relatório apresentado por Carlos Millan revelava também a preocupação com as “técnicas industriais de produção, fazendo parte

\footnotetext{
${ }^{46}$ Ibid: 39

${ }^{47}$ Pereira, Miguel, 2005: 113 e em entrevista concedida à autora, 2006.

${ }^{48}$ Albuquerque, R. Portugal, 2004: 58.
} 
delas um sem-número de elementos e equipamentos produzidos industrialmente. É necessário, portanto, formar o arquiteto no conhecimento e na utilização dessas matérias técnicas, abrindo dentro de seu curso um capítulo especial dedicado ao que chamamos comumente de desenho industrial" ${ }^{50}$.

A proposta de reforma da FAU-USP e também a da FAU-UFRGS, entre outras, enquadravam-se no modelo de ensino de arquitetura chamado de Ateliê Central e representavam um esforço de organização dos cursos de arquitetura, contrapondo-se aos modelos seriados vigentes na época. Esse modelo de ensino visava afirmar a necessidade de formação dos arquitetos, que se caracterizavam pela capacidade de síntese-criação e pela sua participação específica no momento histórico brasileiro; a estrutura operacional mais adequada resultou da análise da experiência de ensino de outros países e de uma discussão em âmbito nacional. 0 departamento de projeto, com maioria dos professores arquitetos, passou a ser a espinha dorsal do curso, com a formação do Ateliê, permitindo sua estrutura diversas linhas de trabalho, que poderiam ser combinadas horizontal e verticalmente ${ }^{51}$ :

- Comunicação Visual

- Desenho Industrial

- Arquitetura de edifícios

- Planejamento.

Em 1960, o $1^{\circ}$ Encontro de Diretores, Professores e Alunos das Escolas e Faculdades de Arquitetura, realizado em Belo Horizonte, expressou interesse na industrialização da construção, de elementos, móveis e utensílios, ao afirmar que era da maior conveniência que fosse integrada ao ensino de arquitetura e complementada pelo estudo dos problemas de padronização, modulação, normalização e demais

\footnotetext{
${ }^{49}$ Fernandes, Ari e outros, 1976: 127.

${ }^{50}$ Millan, Carlos, 1962: 40.

${ }^{51}$ Fernandes, Ari e outros, 1976: 127.
} 
processos industriais. ${ }^{52}$ Segundo Ari Fernandes, $01^{\circ}$ Congresso Brasileiro de Arquitetos, realizado em 1963, “avança na proposta de políticas de construção habitacional em massa, de programas de grande escala de projeto e construção de equipamentos sociais públicos contratados pelo Estado, de cidades novas a exemplo de Brasília e do desenho industrial como expressão mais atual do projeto arquitetônico. Defende a multiplicação das faculdades de arquitetura e urbanismo no país de acordo com o modelo do Ateliê Central, integrado vertical e horizontalmente; decreta o fim dos currículos tradicionais e das disciplinas acadêmicas de 'composição', que serão substituídas pelas novas disciplinas de projeto urbano, das edificações, de comunicação visual e de desenho industrial" ${ }^{53}$.

Tardiamente, incorporava-se ao ensino de arquitetura, no Brasil como também em outros países latino-americanos, o debate que a Bauhaus tinha realizado nos anos $1920^{54}$, como se verá adiante.

O debate sobre o ensino de arquitetura incluía as propostas de Ateliê fundamentado pela experiência pioneira da Bauhaus, que estava sendo retomada na discussão internacional dos arquitetos nos anos 1960.

A proposta de ensino feita em 1962 e referendada pelo fórum de 1963, na FAU-USP, implicava a criação de um Ateliê único, em que trabalhariam juntos os alunos dos quatro últimos anos, com os temas fazendo parte de uma programação conjunta, numa relação de ensinoaprendizagem caracterizada como de internível. Esse ateliê foi chamado também, em outras faculdades, de Ateliê Vertical.

Segundo depoimentos de arquitetos formados na FAU-USP, que estudaram nos anos 1960, no galpão onde se desenvolviam as atividades de projeto, não existiam divisórias, de maneira que o Ateliê estava integrado fisicamente, mas não havia integração programática

\footnotetext{
${ }^{52}$ Millan, Carlos, 1962: 30.

${ }^{53}$ Fernandes, Ari, 2006, entrevista à autora.
} 
ou curricular entre os diferentes níveis ou entre disciplinas projetuais no mesmo nível, ou seja, a proposta referendada no fórum de 1963 não foi concretizada. O sentido do Ateliê, seja central ou integrado, parecia ter sido deixado ao acaso em encontros espontâneos entre estudantes. 0 único registro de uma experiência integrada nesses anos reporta-se ao primeiro semestre de 1958, quando a Comissão de Ensino da FAU-USP, visando aprimorar os ensinamentos ministrados, aprovou em caráter experimental aula prática conjunta com a participação das cadeiras de Composição, Urbanismo e Paisagismo do $5^{\circ}$ ano.

A reforma de 1962 na FAU-USP expressou as questões que estavam sendo debatidas na América Latina nos diferentes encontros de arquitetura e urbanismo, em que estavam presentes as diversas visões sobre o contexto político-econômico e social desses países, e que incluía o debate sobre o desenvolvimentismo. Para Ari Fernandes, ${ }^{55}$ essa reforma em decorrência do $1^{\circ}$ Fórum de Ensino era o modelo dominante dessas propostas de ensino, que se beneficiavam do fato de o IAB (Instituto de Arquitetos do Brasil) estar, naquele momento, sob a direção dos paulistas.

Cabe aqui lembrar que em setembro de 1963 foi realizado o Congresso Internacional da União Internacional de Arquitetos (UIA), em Havana, Cuba. Artigas $^{56}$ solicitou afastamento da FAU-USP, para comparecer a esse Congresso na qualidade de relator para a América Latina; Mayumi Watanabe Souza Lima ${ }^{57}$ participou fazendo parte da Comissão Julgadora do Simpósio de Ensino de Arquitetura, em que também estava presente 0 arquiteto Paulo Bastos, ${ }^{58}$ que teve importante papel na reabertura da FAU-UnB em 1968 e na criação da FAU-SJ C em 1970. Participaram também desse Congresso estudantes e alguns professores

\footnotetext{
${ }^{54}$ Ver Pronsato, Sylvia A. Dobry, 2005, Capítulo III: a experiência da Bauhaus - quem produz e para quem se produz.

${ }^{55}$ Segundo depoimento à autora, 2006.

${ }^{56}$ Ver Albuquerque, Roberto Portugal, 2004: 174.

${ }^{57}$ Ver currículo apud Lima, Mayumi W. Souza, 1995.

${ }^{58}$ Segundo depoimento à autora, em 2006.
} 
da FAU-UNC, que terão depois importante papel na criação do Taller Total nessa faculdade.

Esse Congresso foi um marco porque nele se revelaram já as diferentes tendências da arquitetura e urbanismo, assim como de seu ensino relacionadas com os diferentes pontos de vista do contexto econômico, social, cultural e político do mundo e em especial da América Latina. Isso é confirmado por Ari Fernandes ${ }^{59}$ quando afirma que essas propostas de ensino de arquitetura passavam pela crítica ao desenvolvimento do capitalismo no terceiro mundo, expressas no Congresso da UIA em Cuba, em 1963. Segundo Boaventura Santos, nos anos 1960 e 1970 as discussões fundamentais giravam em torno das estratégias do movimento socialista, sua composição e viabilidade, 0 papel da classe operária no movimento socialista, a relevância dos novos atores sociais e novas agendas emancipatórias, debates que se realizavam sobretudo no meio estudantil e intelectual.

${ }^{59}$ Fernandes, Ari, 2006, entrevista à autora. 

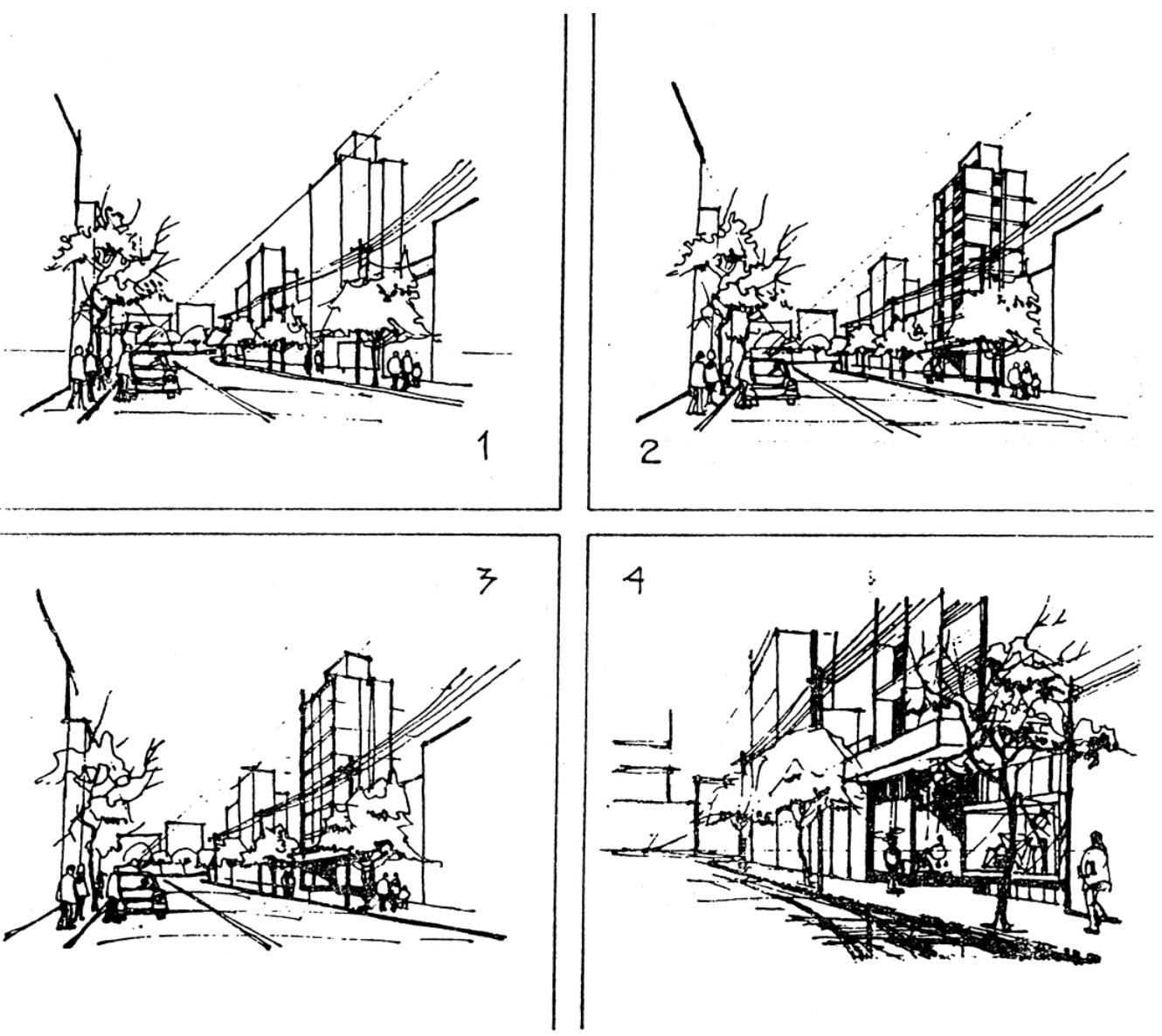

Edifício da FAU-UNC e seu entorno

desenho de Sylvia Dobry, publicado por FERREI RA CENTENO, Raul, 1973: 7. 

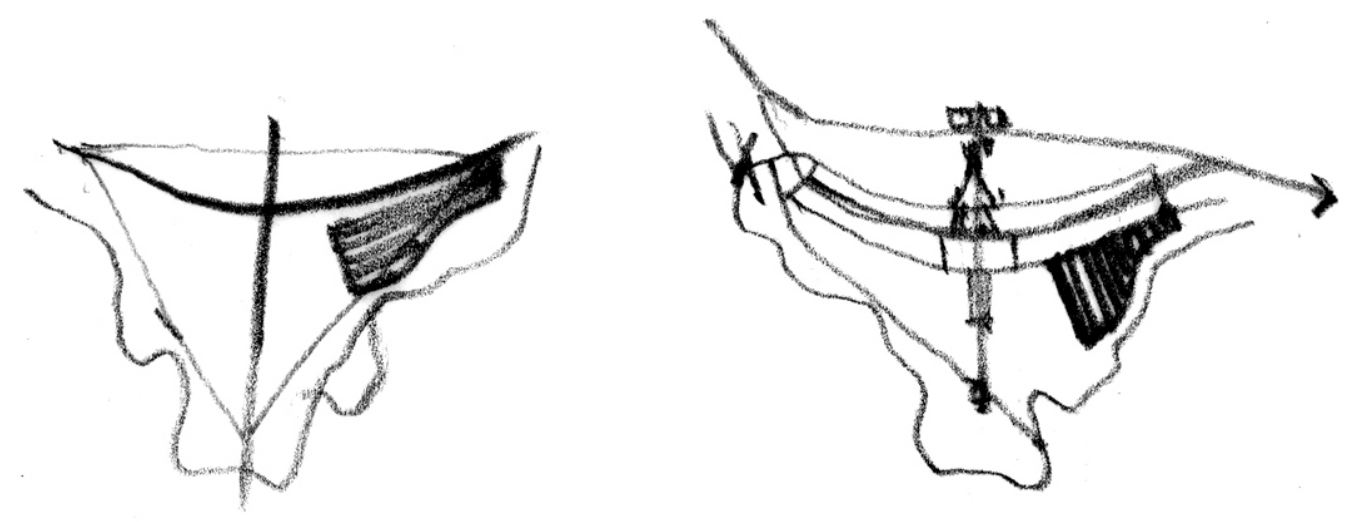

Localização da UnB (intervenção realizada pela autora em desenhos originais de Lucio Costa para o Plano Piloto de Brasília).

Originais publicados pela revista au arquitetura e urbanismo no 38, outubro/ novembro 1991. 


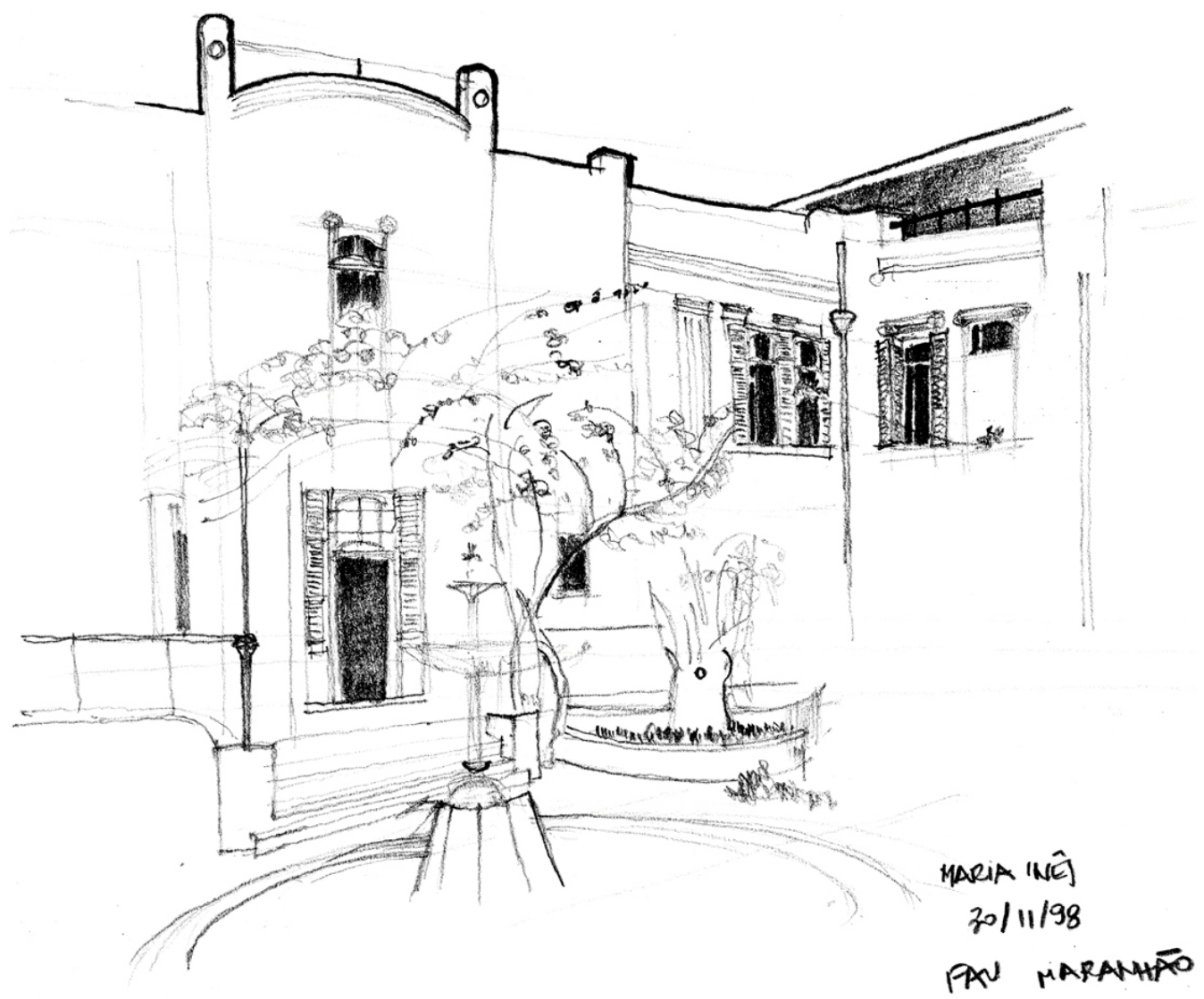

Edifício da FAU-USP à Rua Maranhão.

Desenho de Maria Inês Ghiraldelli Fiaschi, 1998. Arquivo pessoal da autora. 


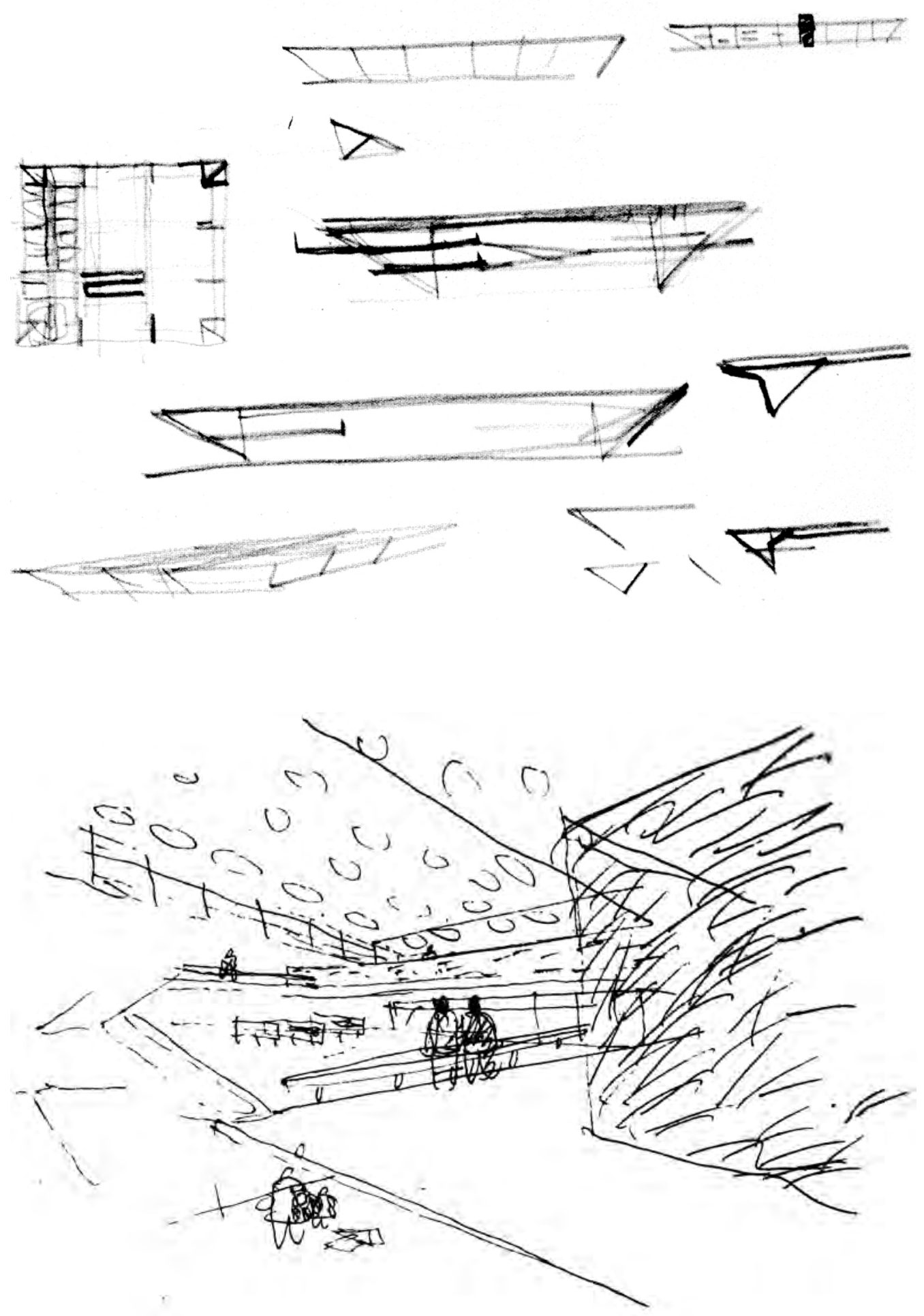

Riscos originais para o edifício da FAU-USP na Cidade Universitária. ARTIGAS, J oão Batista Vilanova, 1998. 
Capítulo III

DITADURAS E ENSINO DE ARQUITETURA $\in$ URBANISMO São Paulo - Brasília - Córdoba

\section{Considerações iniciais}

Como afirmado nos capítulos anteriores, com o golpe militar de 1964 ocorreram mudanças na elaboração da política educacional.

No começo de 1965, em São Paulo, o candidato menos votado da lista tríplice foi designado diretor da FAU-USP: o engenheiro elétrico Pedro Moacir do Amaral Cruz, que reinstituiu a primazia do sistema de ensino predominante nas disciplinas técnicas da época, qual seja, a aula expositiva, deixando de lado as conquistas do sistema de ateliês, considerado mero artesanato pelo diretor ${ }^{1}$. Nesse embate estão representadas duas visões de ensino, já que o sistema de ateliês, em contraposição ao de aulas expositivas, possibilita a participação mais ativa do aluno, relacionando o pensar e o fazer no exercício didático da ação de projetar. Restringido ao departamento de projeto, confunde, na minha visão, a disciplina projeto com a ação projetual, que por ser um trabalho de síntese deveria envolver também os outros departamentos. Não por acaso o debate sobre ensino de arquitetura retomava, nos anos 1960, a experiência da Bauhaus, que já no manifesto de 1919 apontava a preocupação em ultrapassar as barreiras do ensino abstrato, compreendendo a aprendizagem não só como saber informativo, mas como formação, onde reflexão e ação se

\footnotetext{
${ }^{1}$ Arantes, P. F., 2002: 91. Ver também 'FAU Histórico'. Revista $O$ desenho n ${ }^{\circ} 1,1970$. Esse embate representa a luta pelo poder entre engenheiros e arquitetos na FAU-USP, o que se relaciona também com 'reserva de mercado'.
} 
constituem em partes de um todo e não em dicotomias. Também traz a idéia de que 0 artista individual cresce e se desenvolve na interação com os outros. Nessa mesma época Vigotsky e Luria realizam na Rússia pesquisas que confirmam este conceito: a criação é vista como cooperação, desenvolvendo-se a idéia de equipe no ato de criar.

“Para Michel Ragon a Bauhaus trazia uma revolução no ensino de arte que era, ao mesmo tempo, estética e política. 0 objetivo da totalidade permeava todas as preocupações da escola. A cooperação de várias especialidades em um todo sintetizava as diversas contribuições $[\ldots]^{\prime \prime 2}$.

O embate de 1965 na FAU-USP revelava também, a um ano do golpe militar e coerente com sua ideologia, a intenção de cortar toda possibilidade de ensino crítico. Tentando retomar o modelo mais 'seguro' da Escola Politécnica, Cruz afastou a FAU-USP das diretrizes da Reforma de 1962, impondo diversas atividades contra a opinião de professores e alunos, gerando um descontentamento geral de tal ordem que a escola foi fechada temporariamente e Cruz afastado do cargo de diretor ${ }^{3}$. Em seu lugar assumiu o arquiteto Ariosto Mila, que iniciou a construção do edifício projetado por Vilanova Artigas e Cascaldi e organizou o $2^{\circ}$ Fórum de Ensino na FAU-USP, conhecido como Fórum de 1968, com contexto e conteúdo muito diferentes dos do Fórum de 1962, quando se acreditava que a arquitetura pode ser um instrumento transformador da sociedade e participava da construção da nação 4 .

\footnotetext{
${ }^{2}$ Pronsato, Sylvia A. Dobry, 2005: 83. Ver também Rodrigues, A. J., 1989.

${ }^{3}$ Arantes, Pedro Fiori, 2002: 91. Ver também 'FAU Histórico' . Revista $O$ desenho n 1, 1970.

${ }^{4}$ Essa idéia também está relacionada ao fato de que a tendência modernista liderada por Le Corbusier foi hegemônica no Brasil, com sua famosa frase 'Arquitetura ou Revolução', deixando à margem outras tendências modernistas. Vários autores coincidem em afirmar que a discussão internacional a partir de 1956 dentro do CIAM, com a presença das idéias do Team $\mathrm{X}$, esteve ausente na FAU-USP, assim como, após a Segunda Guerra Mundial, muitos arquitetos da Equipe May imigraram para São Paulo, e contribuíram realizando arquitetura de excelente qualidade, em especial em Higienópolis, permanecendo ausente do ensino da FAUUSP, no anonimato e sem reconhecimento, segundo Paulo Bruna.
} 


\section{O Fórum de 1968 na FAU-USP - 1969 e o Al 5}

Em 1968, quatro anos após o golpe militar, o clima era de tensão política (como visto no capítulo I - Parte II). Nesse contexto, muitos arquitetos passaram a duvidar do poder do Desenho (no sentido de Projeto) como instrumento de transformação social.

O Fórum de 1968 foi o palco de debates acirrados - às vezes de forma cifrada e subentendida, devido à presença controladora dos agentes do Estado - entre duas posições conflitantes. Como dito anteriormente, esse debate político acontecia a nível mundial e latino-americano, como divisor de águas que definia a estratégia seguida por cada grupo político frente às burguesias nacionais, e a necessidade ou não da 'etapa democrática burguesa' como caminho para o socialismo. Isso se traduzia, no campo da arquitetura, na ilusão de que existiria uma burguesia nacional interessada no processo de industrialização da construção, idéia a que estavam intimamente ligados Artigas e Paulo Bastos $^{5}$. Já os grupos que questionavam a 'etapa democrático burguesa' e não confiavam na existência de uma burguesia interessada em solucionar o problema de habitação para as grandes massas pesquisaram sistemas de construção a partir de técnicas populares, tendo em vista sua racionalização e aplicação em larga escala, tais como os pré-fabricados in situ. Nesse grupo incluíam-se Sérgio Ferro, Rodrigo Lefèvre, Flávio Império, Mayumi W. Souza Lima, Sérgio Souza Lima, Ermínia Maricato, Edgard Graeff, entre outros.

“Talvez uma das repercussões mais ilustrativas do racha de 1968 tenha sido o surgimento simultâneo de duas revistas de estudantes da FAUUSP em 1970, uma chamada O Desenho e a outra Ou..., quer dizer desenho 'ou' outra coisa"6.

\footnotetext{
${ }^{5}$ Porém Paulo Bastos disse, em entrevista à autora, que era uma ilusão que se constatou errada com o tempo; e que nos anos 1970 Artigas já duvidava que pudesse se realizar.

${ }^{6}$ Arantes, P. F., 2002: 94.
} 
Na revista $O$ Desenho defendia-se a atividade profissional acima de outras, reproduzindo no primeiro número parte de uma aula de Artigas de 1967: "Desenhar é fazer a história como iniciativa humana". Também no ano 1967 Flávio Motta escreveu o conhecido texto 'Desenho e emancipação', que se refere às acepções da palavra desenho em inglês: design como projeto e drawing como representação. É inegável a inspiração de Artigas e Flávio Motta no texto de Giulio Carlo Argan, Projeto e destino, de 1961. "O mote inicial de Argan, desenho é desígnio, assemelha-se ao de Artigas, mas a interpretação do desenho como 'reificação' do projeto em destino, está mais próxima daquela de Sérgio Ferro [...]"

O quarto número da revista $O$ Desenho publicou o projeto do conjunto habitacional Zezinho Magalhães, em artigo que se refere ao Estado como "Legítimo espaço de atuação do arquiteto", por ser o agente com capacidade de "servir às necessidades a aos interesses sociais do país"'.

Por outro lado, a revista Ou... inspirava-se nas aulas de Sérgio Ferro (1968-1969), que criticavam a divisão do trabalho no canteiro de obras e a separação entre trabalho manual e intelectual ${ }^{9}$. Para ele o racha representava divergências teóricas: "Mais que variantes estéticas, estas opções refletiam o debate ético e político que animou a FAU [USP] destes anos: grosseiramente, o confronto entre a busca prioritária do desenvolvimento das forças produtivas em Arquitetura (Artigas) contra a crítica das relações de produção e de exploração (Flávio Império, Rodrigo e eu)"10.

Rodrigo Lefèvre, em entrevista a Renato Maia, minimizou as conseqüências do 'racha' ao dizer que "achávamos que talvez fosse importante, em um certo momento, pensar um pouco e apreender a

\footnotetext{
${ }^{7}$ Arantes, P. F., 2002: 11.

${ }^{8}$ Ibid.

${ }^{9}$ Ibid: 94.

${ }^{10}$ Ferro, Sérgio,apud Santos, Maria C. Loschiavo, 1988: 272.
} 
pensar um pouco antes de fazer uma atividade profissional". Afirmou também que a idéia de que "não se devia trabalhar na prancheta, que não se devia produzir desenho" atribuída ao grupo não correspondia à verdade $^{11}$.

Sérgio Ferro e Rodrigo Lefèvre participaram ativamente do Fórum de 1968-69 de ensino na FAU-USP, defendendo "uma ação política mais veemente do que a simples atividade profissional"12.

A construção do prédio da FAU-USP na Cidade Universitária ,projeto de Vilanova Artigas e Carlos Cascaldi, desenvolvido em 1961 e inaugurado em 1969, "totalmente concebido para abrigar o modelo de ensino do ateliê integrado"13, configurava uma proposta física para conter uma nova proposta pedagógica.

Para Albuquerque, o edifício seguia as premissas gerais que Artigas definia para os projetos de escolas desde o final dos anos 1950: escolas com espaços que contribuíssem para o processo pedagógico - como agentes do processo de aprendizado - , contendo propostas educacionais. Pensava que o convívio com os pares em um espaço democrático e generoso levaria à prática democrática, da mesma forma que o convívio da cidade era criativo e conflituoso. 0 edifício da FAUUSP era, segundo o autor, "uma nova maneira de pensar uma escola, pensar o processo de aprendizado, de produção de conhecimento"; o espaço desse prédio é como o espaço da cidade: tem ruas, praça, funções articuladas e integradas a essa praça, o grande pátio central para atividades coletivas e eventos. "Não tem portas para chegar até a praça. Todas as atividades estão sob o mesmo teto. É o caminho da liberdade e da humanização... a cobertura é vazada, translúcida, com a

\footnotetext{
${ }^{11}$ Lefèvre, Rodrigo, entrevista a Renato Maia, apud Koury, Ana Paula, 1999: 198.

12 Arantes, P. F., 2002: 238 e 242. Ver também Koury, Ana Paula, 2003: 122.

${ }^{13}$ Fernandes, Ari, entrevista à autora, 2006. Ver também Albuquerque, R. Portugal, 2004: 98.
} 
luz que vem do céu criando um universo dedicado ao estudo e ao conhecimento"14.

Ainda segundo Albuquerque, em 1968 a proposta na FAU-USP foi a de revisão dos métodos de ensino em todos os Departamentos e a criação do Ateliê Interdepartamental, encarregado de realizar uma pesquisa global.

Foram propostas as Disciplinas Optativas e Disciplinas Obrigatórias, consideradas básicas. As primeiras seriam formuladas a partir da convivência de professores de todos os departamentos, no Ateliê Interdepartamental, em pequenos projetos integrados ${ }^{15}$.

A idéia do projeto de arquitetura como instrumento transformador da sociedade, na que se incluía a intensificação do sentimento nacionalista característico do período desenvolvimentista, permanecia implícita nos Documentos e Relatórios das Comissões e Sub-comissões do Fórum de julho de 1968 na FAU-USP, onde se afirma, por exemplo, que caberia ao Fórum considerar a "avaliação estética das obras e realizações que mais de perto exprimem o ser humano brasileiro, seu viver social, suas ansiedades, e que por isso, se definem menos pela objetividade técnica. Racionalizar esses significados corresponde a traçar rumos para a cultura nacional e transformá-la em instrumento de emancipação econômica e de desenvolvimento"16.

O Fórum de 1968 redefine os Departamentos em:

- Departamento de Projeto (antiga Composição)

- Departamento de História

- Departamento de Construção

- Departamento de Ciências

\footnotetext{
${ }^{14}$ Albuquerque, R. Portugal, 2004: 107. Seria interessante, em pesquisa futura, fazer uma análise crítica desse modo de projetar, que também inclui questões com relação à vivência cotidiana do usuário, tais como as problemáticas de isolamento térmico e acústico, que se estendem até hoje nos projetos de arquitetos que podem ser considerados discípulos, por exemplo muitos dos edifícios dos CEUs no contexto positivo que eles representam.

${ }^{15}$ Albuquerque, R. Portugal, 2004: 114.

${ }^{16}$ Fórum de Debates, 1968: 05. Grifo nosso.
} 
Propõe diretrizes e programas das atividades interdepartamentais em três instâncias: o Fórum, o Museu e o Ateliê Interdepartamental.

Para o Fórum delega-se a responsabilidade de realizar anualmente um balanço geral das atividades da faculdade, discutir e reformular 0 ideário de ensino e pesquisa da arquitetura e estabelecer a problemática do próximo ano.

A função do Museu era coordenar e divulgar as "atividades curriculares e extracurriculares, de ensino e pesquisa, na graduação e na pósgraduação, conforme a problemática básica adotada pelo Fórum"17.

O Ateliê I nterdepartamental devia realizar, com a participação de professores de vários departamentos e de alunos, pesquisas em arquitetura que tivessem caráter de trabalhos interdepartamentais, não participando, segundo Albuquerque, diretamente do ensino.

O Relatório do Fórum de Debates 1968 conclui com dois depoimentos: o do professor Rodrigo Lefèvre pelo Departamento de Construção e o do professor Paulo Mendes da Rocha pelo Departamento de Projeto ${ }^{18}$.

No final de 1968, com a publicação do Al-5, deu-se o endurecimento do regime, que até esse momento tinha concentrado seu aparelho repressivo prioritariamente no movimento operário e político.

A FAU, ao ser transferida para o novo campus da Cidade Universitária, quase fora da área urbana, refletiu o grande esvaziamento político que se produziu naquele momento. Seu novo edifício, projetado em 1962, adquiria um sentido diferente do imaginado originalmente: em vez do lugar onde seria projetada a nova sociedade, "torna-se um exílio (entre idílico e lúgubre) para os que ficaram; no mesmo ano de 1969 Vilanova Artigas foi cassado e, assim como muitos outros professores da USP tais como Florestan Fernandes, Caio Prado Jr., Elsa Berquó, Mário

\footnotetext{
${ }^{17}$ Ibid.

${ }^{18}$ Documentos e relatórios das Comissões e Subcomissões, Fórum de Debates, 1968: 44-50, apud Albuquerque, R. Portugal, 2004: 119-120.
} 
Schemberg, Octavio Ianni, Fernando Henrique Cardoso, Paul Singer -, aposentado compulsoriamente" ${ }^{\prime 19}$. Os professores que restaram ficaram sem reação, amedrontados: o efeito desmobilizador foi profundo.

\section{Reabertura da FAU-UnB em 1968}

Em abril de 1964 a UnB foi invadida por tropas da polícia militar, que fortemente armadas vasculharam as dependências em busca de armas, prendendo alunos e dezessete professores. Darcy Ribeiro, entre outros, teve seus direitos políticos cassados, vários integrantes do corpo docente foram demitidos e estudantes expulsos da universidade.

Os militares destituíram Anísio Teixeira quatro dias após a invasão, nomeando Zeferino Vaz como reitor, que intercedeu para a liberação dos professores e estudantes presos; porém, um mês depois, o reitor expulsou nove professores e quatro instrutores, entre eles 0 arquiteto J osé Zanini Caldas, o jornalista Perseu Abramo e o sociólogo Ruy Mauro Marini, causando a primeira crise na $U_{n \rightarrow}^{20}$.

Em Brasília, a ação da polícia durante a ditadura foi uma das mais violentas; a UnB foi invadida cinco vezes nos anos que se seguiram ao golpe de 1964, resultando na prisão e tortura de professores, alunos e líderes estudantis, que acabaram se exilando em outros países para poder fugir das perseguições ${ }^{21}$.

Em outubro de 1965, após nova invasão de tropas que durou uma semana, a crise na UnB alcançou seu ponto mais alto com a demissão arbitrária de quinze professores considerados subversivos. Argumentando não haver condições mínimas de ensino, pesquisa ou outros trabalhos intelectuais, mais de duzentos professores pediram demissão, entre eles J osé Filgueiras Lima, J ean Claude Bernardeth,

\footnotetext{
${ }^{19}$ Albuquerque, R. Portugal, 2004: 111.

${ }^{20}$ Gasparoto, Rafael, 2004: 01, in www.radiobras.gov.br/especiais/Golpe64/golpe64_unb2.htm?materia=179996\&editoria; acesso 29/08/2007.
} 
Edgard Graeff, Mayumi S. Lima e o coordenador do ICA, Alcides Áquila da Rocha, ficando o curso de arquitetura praticamente sem docentes ${ }^{22}$. Outros professores exoneram-se em seguida, chegando a um total de 223, ou seja, $79 \%$ do corpo docente.

Após a demissão coletiva, contrataram-se, às pressas, novos professores que não foram bem recebidos pelos alunos durante dois anos. Foram convidados para dar aula no ICA-FAU-UnB desde engenheiros da aeronáutica para aulas de tecnologia até nomes que gozavam de prestígio no próprio ICA/FAU, tais como Roberto Cerqueira César, da USP, Hélio Duarte, da Universidade de São Carlos, S. Vasconcelos, da FAU-MG; os alunos, insatisfeitos, iniciaram em outubro de 1967 uma greve que duraria muitos meses, provocando nova crise, que teve repercussão dentro do grupo que dirigia a UnB, que terminou adotando uma estratégia mais diplomática com o objetivo de conter 0 movimento estudantil ${ }^{23}$.

Em reunião do Conselho Diretor em novembro de 1967, o reitor Laerte Ramos de Carvalho renunciou, não sem antes discutir o problema da FAU, ao apresentar as conclusões da Comissão de Sindicância por ele nomeada para estudar a crise ${ }^{24}$.

A reitoria foi assumida por Caio Benjamin. O Conselho Diretor determinou que se mantivessem as aulas no ICA-FAU durante 0 segundo semestre, compensando os dias letivos perdidos no início de 1968 e autorizando o reitor a constituir uma comissão para estudar e propor medidas necessárias a essa retomada. Para isso, em janeiro de 1968 contratou-se um grupo de professores provenientes do Paraná,

\footnotetext{
${ }^{21}$ Tahan, Lilian, 2004, in clipping. planejamento.gov.br/Notícias.asp?NOTCod=113299; acesso 18/08/2007.

${ }^{22}$ Bastos, Paulo, 2006 e Pereira, Miguel, 2006, em entrevista à autora. Para ele, a renúncia foi um erro; já para o ex-professor do ICA Luis Humberto Martins Pereira, “o sonho já tinha acabado, havia uma inviabilidade total. Quem estava lá sentia que não havia como resistir. Se ficássemos, seria em silêncio, diluindo a universidade, em uma falsa posição de resistência. O golpe acabou com a UnB”. www.arte.unb.br/ida_historia/65a70.htm; acesso 20/08/2007.

${ }^{23}$ Ibid. Segundo Carpintero, Hélio Duarte era considerado professor de grande qualidade. O descontentamento se originava possivelmente da estrutura vigente, da qual o ensino crítico e democrático, que havia caracterizado a origem do ICA-FAU, estava ausente nesse período. ${ }^{24}$ Capintero, 1998: 01 in www.arte.unb.br/ida_historia/65a70.htm; acesso 20/08/2007.
} 
entre eles os arquitetos Maria e Roberto Gandolf, ganhadores de prêmio pelo projeto do edifício da Petrobrás, Jaime Lerner e Leo Bonguestap, profissionais de reconhecida qualidade. Porém, os estudantes entenderam que esses professores não compartilhavam as idéias implantadas no ICA-FAU. Afirmando que desejavam fazer arquitetura e urbanismo para a sociedade brasileira e não tinham como objetivo principal ganhar concursos, os estudantes, em Assembléia Geral, votaram contra o reinício das aulas, apoiando comunicado do Diretório Acadêmico do ICA ${ }^{25}$.

Diante dessa situação, o reitor, Caio Benjamin, muito hábil politicamente, convidou Oscar Niemeyer para a reestruturação do curso de arquitetura. Niemeyer recusou o convite em solidariedade aos 223 professores que haviam sido demitidos, e sugeriu a assessoria do IAB (Instituto de Arquitetos do Brasil) para a contratação de professores, o que foi aceito pelas lideranças estudantis ${ }^{26}$.

Para compreender melhor esse processo, que se relaciona com a formação posterior da FAU-SJ C (São J osé dos Campos), é necessário lembrar que, como visto no Capítulo I, Parte II, se por um lado, com a ditadura militar iniciada em 1964, o projeto de construção de uma universidade crítica de si e da sociedade - que contava com o compromisso de grande parte dos estudantes e docentes - sofreria grandes modificações, por outro lado, esse projeto de modernização de ensino, de que fizeram parte o ITA em São J osé dos Campos e a UnB, continuou integrando e orientando a política educacional durante o governo militar, entre outros motivos, por questões de visibilidade internacional.

É isso que explica a coincidência de forças antagônicas em um mesmo projeto de reabertura da FAU-UnB e a aceitação por todas as partes

\footnotetext{
${ }^{25}$ Capintero, 1998: 01 in www.arte.unb.br/ida_historia/65a70.htm; acesso 20/08/2007.

${ }^{26}$ Bastos, Paulo e Pereira, Miguel, 2006, em entrevistas à autora. Ver também Carpintero, 1998, in www.arte.unb.br/ida_historia/65a 70.htm; acesso 20/08/2007.
} 
envolvidas da intermediação do IAB para assessorar as novas contratações $^{27}$.

A primeira reunião do grupo de trabalho formado para reestruturar 0 ICA-FAU foi realizada no fim de maio de 1968, com a participação do reitor, de professores, estudantes e do presidente do IAB. Neudson Braga, da Universidade Federal do Ceará, foi indicado por consenso para coordenar os trabalhos ${ }^{28}$. As outras indicações do IAB foram: Paulo Mendes da Rocha, da FAU-USP, que por impossibilidade de comparecer foi substituído por Paulo Bastos; Miguel Alves Pereira, da FAU-UFRG; Liberal de Castro, da FAU-UFCeará, e Paulo Magalhães, da $\mathrm{UnB}^{29}$.

Para entender o contexto em que se deu a reabertura da FAU-UnB, é conveniente lembrar que quase dois meses antes dessa reunião, no Rio de Janeiro, foi morto a tiros pela polícia militar, em 28 de março de 1968, o estudante secundarista Edson Luis. A seu enterro compareceram 50 mil pessoas e o episódio agravou o enfrentamento entre os estudantes e o governo militar ${ }^{30}$.

Após o anúncio dessa morte, os estudantes da UnB se encaminharam ao Congresso Nacional e apoiaram os oradores que se manifestavam contra o ocorrido; 3 mil estudantes, em Assembléia Geral, decidiram manter em reunião permanente o Conselho de Representantes da FEUB (Federação de Estudantes Universitários Brasileiros), realizar passeata, suspender as aulas, realizar vigília no campus e dar o nome de Edson Luis a uma praça situada no campus da UnB ${ }^{31}$.

Em todo o país, eclodiram episódios de enfrentamento entre a polícia e os estudantes, instaurando-se uma das maiores crises políticas do governo Costa e Silva; em 3 de abril de 1968 o reitor da UnB

\footnotetext{
27 Ibid.

${ }^{28}$ Ibid.

${ }^{29}$ Bastos, Paulo e Pereira, Miguel, 2006, em entrevistas cedidas à autora.

${ }^{30}$ www.arte.unb.br/ida_historia/65a70.htm; acesso 20/08/2007.

31 Ibid.
} 
determinou o fechamento da FEUB por considerá-la uma entidade alheia à estrutura legal de organização estudantil ${ }^{32}$.

Nesse clima, continuaram as tratativas para a reabertura da FAU-UnB; segundo Paulo Bastos, foram mais de seis meses de intensa atividade, num clima de profunda tensão. As reuniões realizavam-se no campus ou no hotel onde se hospedavam os professores visitantes. Em muitas ocasiões, as lideranças estudantis participantes precisaram esconder-se, ante a irrupção de forças policiais ou militares no local, até mesmo com utilização de tanques no campus ${ }^{33}$.

O Grupo de Trabalho indicou, em junho de 1968, o arquiteto Paulo Barbosa Magalhães como coordenador do ICA-FAU e sugeriu retomar as atividades acadêmicas partindo de uma união da comissão com a plenária dos estudantes, contando com a presença do reitor ${ }^{34}$.

\author{
A Comissão de Reestruturação era paritária, e entre os estudantes \\ destacava-se J osé Antônio Prates ${ }^{35}$.
}

\footnotetext{
${ }^{32}$ www.arte.unb.br/ida_historia/65a70.htm; acesso 20/08/2007.

33 Bastos, Paulo, 2006, em entrevista concedida à autora. Em depoimento a Castro, André Augusto, editor online da Assessoria de Comunicação da UnB Agência, publicado em 24/06/2005, Neudson Braga "se lembra que viveu um período muito tenso durante os oito meses que esteve no campus. Ele presenciou a união entre professores e estudantes que permitiu a continuidade do curso [...]. fomos ameaçados várias vezes, tivemos de sair por conta de invasões policiais. Foi um processo muito doloroso e perigos, mas conseguimos”; in www.unb.br/acs/unbagencia/ago05-76. htm; acesso 19/08/2007.

${ }^{34}$ www.arte.unb.br/ida_historia/65a70.htm; acesso em 20/08/2007.

${ }^{35}$ Bastos, Paulo e Pereira, Miguel, 2006, em entrevistas à autora. Segundo esses arquitetos, Prates foi importante nesse momento crítico da FAU-UnB, durante o fechamento do curso em 1967, período da demissão de todos os docentes. Prates foi torturado e preso (pela segunda vez) quando estava cursando o penúltimo semestre, em 1969. Ao sair da prisão, ficou clandestino e depois se exilou, voltando pela lei de Anistia. Foi reintegrado à FAU-UnB só em 2003, realizando dois trabalhos para finalizar sua graduação: um ensaio sobre o movimento estudantil nos fins de 1960 e início de 1970, com referência educacional e pedagógica da UnB, orientado pelo professor Cariello, Orlando e um trabalho urbanístico, no qual elaborou o Plano Diretor para Salinas, sua cidade natal, orientado pelo professor Furtado, Aleixo, professor da Universidade e também líder estudantil na época. De sua banca de graduação participou o professor Pereira, Miguel, em fevereiro de 2004. Posteriormente, eleito prefeito de Salinas, aplicou esse Plano Diretor, com participação popular. Outras lideranças estudantis, Guimarães e Celestino, que desapareceram, foram presos juntamente com Prates, que dedicou a eles o momento especial da recuperação de sua cidadania, como reconhecimento histórico a essa geração que lutou por este país. Ver também: Castro, André Augusto, 2004 in www.br/acs/unbagencia/ag0204-04.htm; acesso 19/08/2007.
} 
A estrutura a ser criada, segundo Paulo Bastos, não poderia ser igual à anterior e deveria contentar tanto os estudantes quanto a ditadura: ou seja, era uma situação muito complicada.

A comissão paritária de reestruturação reafirmou no seu relatório final a "verdadeira posição que o ICA deve ocupar na UnB como centro de formação básica, colocando à disposição de toda a Universidade uma larga faixa de conhecimentos neste setor extremamente importante da cultura"36. $^{36}$. relatório destacava que o ICA deveria desenvolver atividades orientadas para um objetivo relacionado à cultura de massas, evitando um conteúdo acadêmico tipo Belas Artes; para isso propunha a estruturação de um Departamento de Música e a formação de um Ateliê de Cinema ${ }^{37}$.

Em linhas gerais, segundo Paulo Bastos, a estrutura proposta pela Comissão de Reestruturação baseava-se na reunião de conhecimentos em várias áreas; não partia de uma visão profissionalizante exclusivamente pragmática, mas de um curso básico incluído no Instituto Central de Artes, de quatro semestres, que abriria o universo cognitivo da arte, 'descortinando' uma visão desconhecida pela maioria dos ingressantes no campo das artes, das ciências, da tecnologia, das humanidades. Nos primeiros anos pretendia-se o contato, a observação e a criação no campo das artes e só nos últimos três anos o aluno cursaria a área profissional escolhida: o resultado seria uma formação não estreita, com uma ampla base de conhecimentos ${ }^{38}$. Estabeleceu-se, ainda segundo o arquiteto Paulo Bastos, um sistema de disciplinas obrigatórias, complementares e optativas, o que possibilitava uma rica combinação, através da escolha sempre realizada com a orientação de professor.

Para implantar a proposta da comissão paritária, realizou-se em agosto o Seminário de Reestruturação ICA-FAU, também conhecido como 1o Fórum ICA-FAU, de cuja organização participaram o Dacau (Diretório

\footnotetext{
${ }^{36}$ www.arte.unb.br/ida_historia/65a70.htm; acesso em 20/08/2007.

${ }^{37}$ Bastos, Paulo, 2006, em entrevista à autora.
} 
Acadêmico de Arquitetura e Urbanismo) e o Daica (Diretório Acadêmico do Instituto de Artes). Nesse seminário apresentou-se a programação do segundo semestre de 1968 e abriu-se um debate tendo em vista a programação do ano seguinte ${ }^{39}$. Foi proposto como coordenador do ICA-FAU 0 arquiteto e professor Miguel Alves Pereira ${ }^{40}$.

Em meados de julho foi decretada a prisão preventiva de sete estudantes, entre eles Honestino Monteiro Guimarães, presidente da FEUB, e J osé Antônio Prates, liderança do Dacau que não esteve "livre para ver a FAU reaberta em agosto pela comissão paritária; saindo da prisão em setembro desse ano, Prates foi eleito presidente da FEUB". ${ }^{41}$ Em 29 de agosto, em uma operação conjunta, da qual participaram forças da polícia do Exército, Polícia Militar, Polícia Civil e Polícia Política (Dops), a UnB foi invadida violentamente. Aproximadamente 500 estudantes foram conduzidos de mãos na cabeça até a quadra de basquete, sendo 60 presos e um baleado no olho ${ }^{42}$. Esse conflito teve grande repercussão. No Congresso Nacional parlamentares condenaram a invasão. As aulas no ICA-FAU permaneceram suspensas, até 15 de outubro daquele $a^{43}$.

No dia 13 de dezembro, o governo militar anunciou ao país o Al5, o mais terrível instrumento de força utilizado pelo governo, e o Ato Complementar no 38 , que decretou o recesso do Congresso Nacional por tempo indeterminado.

Nesse contexto, o professor Miguel Pereira realizou, entre 17 e 31 de dezembro, o Seminário de Revisão e Consolidação dos Planos de Ensino e Abertura do Projeto Cultural do ICA-FAU, no qual foram apresentadas

\footnotetext{
${ }^{38}$ Bastos, Paulo, 2006, em entrevista concedida à autora.

${ }^{39}$ Bastos, Paulo, 2006, em entrevista concedida à autora. Pereira, Miguel, 2006, em entrevista concedida à autora.

${ }^{40}$ Ibid. Paulo Bastos, destacou que a FAU-UFRG era uma das mais organizadas e avançadas na época. A nomeação de um professor que provinha dessa instituição possibilitava trazer uma experiência interessante à FAU-ICA, na minha visão.

${ }^{41}$ Castro, André Augusto, UnB Agência, 06/02/2004_in www.unb.br/acs/unbagencia/ago05-

76.htm.,acesso 19/08/2007.

42 www.arte.unb.br/ida_historia/65a70.htm acesso 20/08/2007.

43 Ibid.
} 
as contribuições de cada departamento visando o Fórum do ano seguinte ${ }^{44}$.

Esse seminário era parte de um processo de reflexão crítica e pretendia, entre outros aspectos, verificar a metodologia de trabalho a ser adotada, visando a construção de uma proposta cultural diferenciada. Nela, a produção e o ensino de arte deveriam se caracterizar por uma flexibilidade metodológica que evitasse idéias superadas isolando a obra de arte da realidade contemporânea em que ela se inseria. Uma das conclusões do seminário foi que "para tanto é preciso ligar o ensino de Arte à sua realização, como integração ao real, orientando e desenvolvendo a capacidade dos alunos através de um processo racional de conhecimento que forneça o instrumento necessário à criação e à atuação na cultura brasileira"45. Considerou-se a necessidade de formação de profissionais atuantes no processo de desenvolvimento social, dispondo a arte no mesmo plano da ciência e da tecnologia como meios de expressão e também de controle da realidade ${ }^{46}$.

O segundo Fórum ICA-FAU realizou-se de 10 a 16 de março de 1969; nele discutiram-se os projetos dos grupos de trabalho e das áreas participantes. Os dois fóruns concluíram, o que está registrado em seus relatórios, que um dos problemas estruturais de maior gravidade que deveria ser enfrentado era a impossibilidade de um planejamento adequado para a efetivação dos objetivos de acordo com cada etapa ${ }^{47}$.

Também nesse fórum foi apresentado e discutido o projeto Cediarte (Centro de Documentação e Informação de Arte), cuja motivação, tanto no âmbito da cultura quanto no da didática, era a necessidade inadiável de documentar a arte, em especial a brasileira. 0 projeto

\footnotetext{
${ }^{44}$ www.arte.unb.br/ida_historia/65a70.htm. Também Pereira, Miguel, 2006, entrevista concedida à autora.

45 Ibid.

${ }^{46}$ www.arte.unb.br/ida_historia/65a70.htm: 03 e 04; acesso 19/08/2007. Grifo nosso.

${ }^{47}$ Ibid.,grifo nosso.
} 
Cediarte fundamentava-se no Projeto Cultural da UnB e do ICA-FAU, participando dele como Unidade Complementar, estruturalmente relacionada à Biblioteca Central, à Editora UnB, à Faculdade de Biblioteconomia e Informação Científica e também ao futuro Museu da $\mathrm{UnB}^{48}$.

Destacava-se como seu principal objetivo "elaborar, orientar e executar, juntamente com os demais órgãos de documentação da UnB, o Plano Geral de Documentação, Informação e Divulgação de Arte, especialmente a Arte Brasileira, inclusive nos aspectos referentes à museologia e à edição, e noutros que lhe sejam afins" ${ }^{\prime 9}$.

Pode-se detectar nos relatórios desses seminários e fóruns do ICA-FAU opiniões próprias desse momento, tais como a idéia de que os processos racionais, seja na arte, seja na ciência ou na técnica, considerados muito importantes e desejáveis, dariam conta da cultura, em especial a brasileira, sendo possível controlar a realidade. Não se pode deixar de observar o parentesco com o pensamento do pintor abstrato e professor da Bauhaus W. Kandinsky, que em 1926 publicou Ponto e linha sobre plano, no qual tenta estabelecer as bases de uma futura ciência da arte. 0 que confirma, também nesse aspecto, que a revalorização da Bauhaus nesses anos permeava a teoria e a ação no campo da arquitetura e seu ensino nesse período.

Também o racionalismo, que se revelava em grande parte do pensamento arquitetônico, permeava, de maneira diferente, as idéias dos militares que governavam o país. Ao mesmo tempo que praticavam uma feroz repressão, acreditavam na ciência e na técnica como instrumentos reorganizadores da sociedade ${ }^{50}$.

O paradigma racionalista na arquitetura e urbanismo encontrou na sobrevalorização do planejamento uma de suas expressões, entendendo que a forma poderia organizar a sociedade. Isso

\footnotetext{
${ }^{48}$ www.arte.unb.br/ida_historia/65a70.htm: 04; acesso 19/08/2007.

${ }^{49}$ Ibid.

${ }^{50}$ Oliveira, Francisco de, janeiro de 2006, exposição na banca de qualificação da autora.
} 
combinava-se perfeitamente com "a época de ouro da Cepal, em que o regime estimulava a planificação das cidades" ${ }^{\prime 51}$.

Um ano após ter sido realizado o segundo Fórum do ICA-FAU, em março de 1970, o Conselho Federal de Educação aprovou o novo Estatuto da UnB. Nele se abandonava definitivamente o compromisso com as concepções originais, mantidas até então, assumindo-se critérios de eficiência e racionalidade ${ }^{52}$.

A UnB organizou a reestruturação do Centro de Planejamento (Ceplan), que reviu o projeto da Praça Maior do campus universitário, estabelecendo um novo ritmo em seu planejamento ${ }^{53}$.

A partir da vigência do decreto-lei 477/69, que anulou o movimento político reivindicatório nas universidades, foram renovados, lentamente, os corpos técnico-administrativos e docentes, enquadrando-se a instituição nas diretrizes do governo militar ${ }^{54}$.

De acordo com o artigo 79 do Estatuto da UnB: “Ao Diretório Universitário é vedado exercer atividade ou fazer propaganda de caráter político-partidário, religioso ou racial, bem como promover ou apoiar falta coletiva aos trabalhos escolares". Do ponto de vista administrativo, passado o momento de turbulência, a UnB tomava um novo rumo ${ }^{55}$.

Seu Estatuto da UnB de 1970 previa a extinção do ICA-FAU, com a unificação de ambos no Instituto de Artes e Arquitetura (IAA), que passaria a ser constituído pelos departamentos de Arquitetura e Urbanismo, Artes Visuais e Cinema e Música. Essa nova estrutura, mais

\footnotetext{
${ }^{51}$ Ibid.

52 www.arte.unb.br/ida_historia/estatuto70.htm, acesso 20/08/2007 O estatuto estabelecia que para se instalar uma unidade acadêmica seriam necessários pelo menos três departamentos.

${ }^{53}$ www.unb.br/fau/guia/historico.htm; acesso 19/08/2007. O CEPLAN-UnB (Centro de Planejamento - UnB), criado em 1962, era o órgão encarregado de dar continuidade ao plano elaborado por Lucio Costa e os projetos específicos.

54 Ibid.

${ }^{55}$ www.arte.unb.br/ida_historia/estatuto70.htm; acesso 19/08/2007.
} 
rígida, dificultava a livre atuação dos professores e desconsiderava 0 debate interno entre estes e os estudantes ${ }^{56}$.

Após 1971, foi desmembrado o ICA-FAU, deslocando-se o

Departamento de Música, com o nome de Departamento de Arte, para o Instituto de Comunicação e Expressão; foi fechado o curso de cinema, seus professores demitidos e os alunos enviados com bolsas especiais para Niterói, como por exemplo Tizuka Yamazaki; foi criado o Instituto de Arquitetura e Urbanismo, suprimindo-se a palavra Arte; já o Departamento de Artes Visuais e Cinema passou a ser chamado Departamento de Desenho (DES) ${ }^{57}$.

A direção da FAU-UnB foi exercida pelo arquiteto Miguel A. Pereira entre 1968 e 1976, coincidindo parcialmente com sua gestão como presidente do IAB, de 1972 a 1976. Durante uma viagem a Córdoba, em 1971, Miguel Pereira teve contato com o Taller Total, e tentou, junto com estudantes e professores, repetir a idéia na UnB. Segundo ele, nesse período as resoluções eram tomadas de forma paritária e, a cada seis meses, havia reuniões para discutir o andamento da experiência ${ }^{58}$, cujo tema era o Planalto Central e suas cidades, realizando-se muito trabalho de campo ${ }^{59}$.

Em 1976, assumiu a reitoria da UnB o doutor em física e oficial da Marinha J osé Carlos de Almeida Azevedo, no momento em que os estudantes tentavam reorganizar seus órgãos de representação. Se por um lado tinha havido um grande investimento do governo, que resultou no crescimento físico da universidade, por outro lado, devido ao

\footnotetext{
${ }^{56}$ Depoimento do professor, Conrado Jorge Silvas Marco, in www.arte.unb.br/ida_historia/estatuto70.htm; acesso 19/08/2007.

${ }^{57}$ www.arte.unb.br/ida_historia/estatuto70.htm; acesso 19/08/2007.

${ }^{58}$ Pereira, Miguel A., entrevista à autora, 2006. Ver também,2005: 82.

${ }^{59}$ Pereira, Miguel A., 2006, entrevista concedida à autora. O então estudante de arquitetura da UnB José Manoel Esteves de Castro , em entrevista a autora, em2007,destacou que muitos dos professores de arquitetura participavam do projeto dos edifícios do campus, e levavam os alunos a essas obras: era como se estudassem no interior de um canteiro de obras, o que contribuía enormemente para o processo de ensino-aprendizagem .
} 
controle rigoroso e ao abuso de poder da reitoria, iniciava-se o seu questionamento por parte de professores, estudantes e funcionários ${ }^{60}$. O discurso das autoridades universitárias, centrado no progresso e na eficiência, foi contestado, em 1977, pelos estudantes, que denunciavam a ociosidade dos laboratórios, dos professores e o controle da liberdade de expressão e de organização das representações estudantis - 0 movimento estudantil de Brasília integrava-se às manifestações que aconteciam nacionalmente, assumindo a luta pelas liberdades democráticas e pela anistia ampla e irrestrita para os presos políticos. Porém essas mobilizações terminaram nesse ano, com novas invasões maciças de tropas policiais para reprimir, entre outras coisas, a encenação da peça teatral 0 preço da liberdade é a eterna vigilância e uma assembléia universitária ${ }^{61}$.

O sonho dos estudantes terminava sufocado sob as botas da ditadura, mas expunha para o Brasil e o mundo a hipocrisia e o controle das instituições universitárias pelo regime militar; porém, no ano seguinte, houve modificações: foi a vez de os professores se organizarem para uma maior participação diante do controle imposto pela reitoria, criando-se, em maio de 1978, a Associação de Docentes da Universidade de Brasília (ADUnB), que teria mais tarde papel importante no questionamento da gestão acadêmica e da estrutura burocrática da universidade ${ }^{62}$.

Um maior aprofundamento na análise do processo da FAU-UnB durante os anos 1960 e 1970, por sua influência sobre a FAU-SJ C e sua relação com o Taller Total de Córdoba, embora importante, foge ao alcance desta tese.

\footnotetext{
${ }^{60}$ www.unb.br/fau/guia/historico.htm; acesso 19/08/2007.

${ }^{61}$ www.unb.br/fau/guia/historico.htm; acesso 19/08/2007.

${ }^{62}$ www.unb.br/fau/guia/historico.htm; acesso 19/08/2007.
} 


\section{As origens do Taller Totalem Córdoba - 1968-1970}

Algumas tendências de Arquitetura e Urbanismo consideram que a arquitetura é indissoluvelmente ligada à paisagem, entendida como processo e produto da ação dos homens; outras consideram que a arquitetura refere-se ao projeto do edifício isolado. Adotando o primeiro ponto de vista já durante a pesquisa de mestrado, na busca da gênese do processo participativo, ao realizar entrevistas com arquitetos paisagistas constatei que as idéias participativas partiam de sua formação nas próprias faculdades de arquitetura, na relação com professores e estudantes ligados às lutas populares de resistência à ditadura e às lutas por moradia e educação popular, que evoluíram para preocupações ligadas à paisagem e ao ambiente.

Também durante 0 desenvolvimento de meu mestrado tomei contato com as idéias de Sérgio Ferro, Mayumi Souza Lima, Flávio Império, Rodrigo Lefèvre, percebendo que, de maneira diferente em cada um deles, havia pontos de contato com as idéias debatidas nos anos 1960 e 1970 na FAU-UnC (Córdoba, Argentina), em especial com o debate do Taller Tota/ de Arquitectura, experiência da qual participei. Vários professores da FAU-USP, entre eles Sylvio Sawaia e Miguel Pereira, afirmaram, seja em conversas informais, seja em entrevistas concedidas à autora, que a experiência do Taller Total fora discutida no âmbito da FAU-USP e na FAU-UnB, sendo referência para esta última após sua reabertura nos anos 1970.

Ao focar o objeto de trabalho desta pesquisa de doutorado na experiência de ensino de arquitetura que se desenvolveu nos anos 1970-1976 na FAU-SJ C, considerei que nesse mesmo período estava se realizando o Taller Tota/ de Arquitectura em Córdoba, Argentina. Minha participação nessa experiência considerada pioneira por diversos autores foi, no início, uma forte motivação para a elaboração desta pesquisa. Há coincidências e diferenças entre essas experiências de ensino de arquitetura, desenvolvidas no mesmo período, e em países 
diferentes da América Latina, em momentos conturbados da história desses países: a primeira, no período da ditadura militar brasileira; a segunda, com origem no fim da ditadura militar de Onganía (iniciada pelo golpe de 1966), estende-se até 1976, ano de um novo golpe militar. Esse período, muito conturbado, inclui a volta ao poder e a morte de Perón, como se verá adiante. Pode-se considerar também que as duas experiências de ensino relacionam-se com os movimentos populares de luta pelos direitos de cidadania em cada um desses países, com suas particularidades, cuja análise foge ao escopo desta tese.

Apresento então aqui, por constituir o pano de fundo e ponto de partida da presente pesquisa, uma reflexão sobre meu percurso, de 1962 a 1975.

\section{A memória e a transmissão}

Entre as acepções que o dicionário da língua portuguesa atribui à palavra memorial, escolhi as que revelam maior significação para mim: lembranças, memórias, livro de memórias. Já a palavra memória significa, entre outras coisas: lembrança, vestígio, autobiografia, reminiscência, e vem do latim memoria e do adjetivo latino memor, significando que se recorda, lembrado.

Assim, colocada frente à tarefa de redigir este texto, não posso deixar de pensar que, talvez pela época em que estudei e comecei a vida profissional, minhas lembranças misturam-se com a história dos acontecimentos daquele período. Como afirma Hector Scmucler, "[...] a visão da memória como matriz sobre a qual se fundamenta a conduta, não simplesmente como recordação, é mais complicada, mais dolorosa, e mais conflitiva [...]". Porém, ainda nas palavras desse autor, "a memória não é um problema de construção, é um problema de 
transmissão. Se não houver transmissão, a memória se esgota. Por isto, a memória é uma atividade permanente $[\ldots]^{n 63}$.

\section{Algumas palavras sobre a UNC}

Pelo fato de ter realizado a graduação na Argentina, considero pertinente estender-me sobre a universidade e a faculdade na qual realizei os estudos, que marcaram profundamente minha vida profissional, seja como docente, seja no exercício concreto do fazer arquitetônico, seja como pesquisadora.

A Universidade Nacional de Córdoba foi fundada em 1613 pelos jesuítas, umas das primeiras da América Latina e sua existência, que caracteriza Córdoba como 'cidade universitária', a ser reconhecida como 'la docta' ('a douta').

Em 1925 criou-se a Escola de Arquitetura, na Faculdade de Ciências Exatas, Físicas e Naturais da UNC, funcionando na Escola de Engenharia, sob influência da Reforma Universitária de 1918. A Escola de Arquitetura nasceu junto às primeiras obras de arquitetura moderna, trazidas por renovadores arquitetos europeus. ${ }^{64}$ Entre 1946 e 1955 foram afastados pelo governo Perón os professores progressistas das escolas e universidades. Em 1955, depois da queda de Perón, um grupo de estudantes, cansados do velho espaço de Engenharia, ocuparam um edifício em frente, que foi o primeiro lugar físico da FAU. ${ }^{65}$ Visando a renovação dos professores, abriram-se concursos no país inteiro e os estudantes participaram ativamente dessa reestruturação da FAU. A falta de discussão dos planos de estudo e de formação docente limitava, porém, o crescimento da faculdade: "na época, a FAU-UNC abandonou com soberba irresponsável", segundo Elkin, "temas como o

\footnotetext{
${ }^{63}$ Em reportagem de 23/03/2000 no jornal Página 12, apud Elkin, B. (2000:15).

${ }^{64}$ Elkin, B., 2000:16.

${ }^{65}$ Ibid: 26.
} 
conhecimento de pedagogia para o ensino e a investigação da arquitetura" 66 .

\section{“Universidade e vai-e-vens políticos cruzam os anos 60”67}

As inquietações despertadas já na graduação constituíram raízes profundas para minhas atividades e reflexões atuais.

Ingressei na FAU em 1962 em um curso de 6 anos, período integral. 0 primeiro ano, chamado Preparatório, que pretendia ser uma base instrumental, era considerado 'limitativo' pelos estudantes. Divididas em dois semestres, as disciplinas do Preparatório sedimentaram desde 0 início, uma concepção de arquitetura que inter-relacionava os conhecimentos de várias áreas. Essa concepção poderia sintetizar-se no triângulo de Vitruvio, retomado pela Bauhaus, que conceitua a arquitetura como produto e processo da relação forma, função e técnica, referência marcante no desenvolvimento de minha vida profissional, tanto acadêmica quanto projetual.

Era uma época de muito entusiasmo e muita sede de aprender, muita paixão pela arquitetura. A construção dos conhecimentos transcendia a sala de aula: no bar da faculdade, nas escadarias, nos bares vizinhos à FAU, grupos de estudantes de vários níveis com os projetos desenhados em papel-manteiga abertos nas mesas, discutindo e escutando, ávidos, as opiniões dos colegas das turmas mais adiantadas.

Essas relações informais entre os estudantes de diferentes níveis, as entusiasmadas discussões possibilitavam um crescimento intelectual superior ao esperado pelas atividades restritas, reduzidas às salas de aula. A história da Arquitetura permeava a discussão dos projetos, como referência. Discutia-se também sobre teatro, cinema, dança,

\footnotetext{
${ }^{66}$ Ibid: 27.

${ }^{67}$ Ibid .
} 
música, artes plásticas, questões sociais, a necessidade de industrializar a construção etc.

Segundo Cesar Naselli, o pensamento, o desenho (no sentido do projeto) e a prática arquitetônica argentina participaram, no contexto latino-americano, do "debate e proposta de uma compenetração ambiental de Arquitetura e Cidade. Todo o profissionalismo e a docência estiveram comprometidos nesta discussão prática...". Algumas das raízes dessa atividade projetual provêm, em Córdoba, daquela geração que ofereceu, entre os anos de 1955 e 1975, suas idéias de mudança e renovação no processo projetual arquitetônico-urbanístico. Essas idéias foram, na visão de Naselli, a conjunção daquelas tendências arquitetônicas que formaram essa geração: por um lado, a que recolhe a herança do classicismo com sua harmonia e composição, que provém das Belas Artes, e por outro lado, a que se lhe opõe, desde a Bauhaus, levando a um plano primordial a função e a técnica aliadas a uma outra tendência que traz a "vivência perceptual e sensualista do mundo wrightiano". Assim, surgiu um sincretismo particular, ainda segundo o autor, que faz do arquiteto, em Córdoba e na Argentina em geral, um artista e criador de formas, ambientalista e tecnólogo, preocupado profundamente com a sociologia e a filosofia ${ }^{68}$.

Esta discussão a que se refere Naselli influenciou fortemente o período de minha graduação, destacando-se a atuação de Raul Bulgheroni, responsável pela cadeira de Plástica II, que propunha 0 aprofundamento na percepção e configuração do espaço urbano.

A partir de 1950, urbanistas italianos, La Padula, Devoto e Tedeschi (integrante do grupo Metron), os dois últimos professores de minha turma, fizeram parte do corpo docente transmitindo experiências de Camilo Sitte e as propostas das cidades-jardins, de maneira superposta às idéias dos $\mathrm{CIAM}$.

\footnotetext{
${ }^{68}$ Naselli,Cesar, Homenagem ao Arq.Carlos Eduardo David. Revista Summa, 1984:.25
} 
No ano que antecedeu o golpe militar de 1966, tive o privilégio de ser aluna, em Composição Arquitetônica do professor Hubert Hobbs (com quem também estagiei em1967) e da arquiteta King. Professores estes que marcaram profundamente minha formação e minhas idéias sobre arquitetura.

Nessa disciplina, além dos temas anuais, um sistema de projetos rápidos, de curtíssimo prazo de entrega (esquicios, ou charrettes), conferiam aos alunos o desenvolvimento de uma agilidade projetual incomum.

O golpe militar de 1966 fechou a FAU e nos deixou órfãos de muitos dos melhores professores e arquitetos ${ }^{69}$, a maioria das cadeiras de Composição Arquitetônica. Uns foram afastados, entre eles Taranto e Elkin, outros renunciaram em solidariedade aos colegas, como no caso de Hobbs, que se afastou também da diretoria. Sua carta de renúncia foi referência conceitual, seja na relação universidade-sociedade, seja na defesa de uma prática arquitetônica comprometida com a realidade.

Esses anos podem ser considerados como preparativos do Taller Total, do qual participei como professora. Segundo Arquimedes Federico, ${ }^{70}$ talvez o ponto de inflexão que acelerou a criação do Taller Total de Arquitetura em Córdoba tenha sido, em 1966, o que ficou conhecido como 'la noche de los bastones largos', na Universidade de Buenos Aires, que culminou com o afastamento, em todo o país, dos professores universitários suspeitos de progressistas.

Como diz Federico, é possível dividir a história da FAU-UNC nas seguintes etapas:

\footnotetext{
${ }^{69}$ Durante o golpe militar de Onganía, 66 professores arquitetos foram demitidos na FAU-UnC (Córdoba) por terem participado de uma greve em reação à repressão instalada na universidade, da qual fez parte o assassinato do estudante Pampillón. Segundo a revista Primeira Plana, até agosto de 1966, 14\% do corpo docente da Universidade de Buenos Aires optou por renunciar, entre eles 234 de Arquitetura. Equipes inteiras de pesquisa deslocaram-se para outros países, por exemplo, Estados Unidos, para o qual emigraram 6.543 professores universitários argentinos entre 1950 e 1966, apud Martinez, Silvia A., 2000: 80-81.

${ }^{70}$ Colega de turma, também professor do Taller Total de Arquitetura e atual professor na FAU - UNC, apud Elkin; 2000:129.
} 
1. Anterior a 1966, como uma época progressista de alta excelência acadêmica.

2. De 1966 a 1970, sob o golpe militar de Onganía, começa-se a construir o Taller Total.

3. De 1970 até 1974 , ano da morte de Perón e do Navarrazo (golpe da direita peronista), em Córdoba, etapa do Taller Total por excelência.

4. O golpe militar de 1976 encerra a experiência do Taller Total de forma violenta.

Considero importante descrever aqui algumas questões referentes às etapas 1 e 2 dessa cronologia, que antecipam preocupações sobre a carreira docente durante o período do Taller Total, assim como as idéias sobre a relação desenho, percepção dos lugares e seu projeto.

Na FAU-UNC, antes do Taller Total, a escala inicial da carreira docente era constituída pelas monitorias, desempenhadas por alunos concursados, que recebiam uma bolsa. A estrutura da carreira docente, na época, era piramidal. No topo, o titular, abaixo os adjuntos, a seguir os chefes de trabalho práticos, os auxiliares de ensino e, por fim, os monitores que tinham uma relação direta com os alunos e que desempenhavam um papel importante como intermediários na construção do conhecimento entre os professores distantes e os alunos.

Fui estimulada por colegas a prestar o concurso para o cargo de monitora na cadeira de Desenho (à mão livre), ministrada por Raul Ferreira Centeno, professor titular, tarefa que desempenhei por um ano, de 1967 a $1968^{71}$.

A disciplina pertencia ao nível Preparatório. Mais do que ensinar a desenhar, era uma disciplina que desenvolvia no ingressante do curso de graduação em arquitetura a construção do olhar. Desde o início o aluno era instigado a visualizar o edifício no contexto da cidade. $\mathrm{Na}$

\footnotetext{
${ }^{71}$ A disciplina serviu de base para o livro El Croquis de autoria desse professor, que contém impressos alguns desenhos realizados quando estudante, assim como de colegas de várias turmas.
} 
maioria das aulas percorria-se a cidade de Córdoba desenhando ao ar livre, pranchetinha A4 nas mãos, com lápis 6B (proibida a borracha), vidro de nanquim e bico de pena. Esticando o braço para descobrir as proporções, observando as regras da perspectiva in loco, luz e sombra, texturas, volumes justapostos ou encaixados, hierarquias espaciais etc. No percurso devia-se observar o 'aqui', o 'lá', o 'além' e optar pelo ponto de vista mais 'econômico'.

Essa disciplina era pré-requisito para Elementos de Arquitetura, em que o aluno completava seu aprendizado de representação com instrumentos técnicos (na época: régua, esquadro, compasso) e com base em levantamento dos espaços do quotidiano (sala, quarto, cozinha) aprendia-se Representação Bidimensional (plantas, cortes etc.). A seguir, por meio de estudos ergométricos e de usos (relação homem-espaço) completava-se um repertório que permitia a análise dos espaços levantados e pedia-se ao aluno uma proposta projetual.

Ou seja, pela disposição das disciplinas nos semestres, a idéia era que, desenvolvido o olhar e a habilidade de desenhar em perspectiva de observação (desenho do concreto) e munido dos conhecimentos teóricos oferecidos pela Geometria Descritiva, na disciplina Elementos de Arquitetura, o aluno estaria em condições de começar o processo projetual, com a colaboração dos conhecimentos técnicos da disciplina Elementos de Construções.

Assim, o desenho à mão livre, longe de ser somente a 'ilustração da idéia', tinha um papel formativo inserido no processo de construção da idéia.

Minhas próprias dificuldades como aluna e os caminhos encontrados para superá-las fundamentaram, já nesses primeiros anos de faculdade, a idéia de que o projeto e sua representação gráfica (bi e tridimensional) constituem aspectos de um único processo criativo. A 
possibilidade de representar ou desenhar o espaço potencializa a possibilidade de projetar os lugares de vida.

Num paralelo com as idéias demonstradas por Vigostsky e Luria referentes à relação pensamento-linguagem, em sua afirmação de que o pensamento se desenvolve no exercício da linguagem desde 0 aprendizado das primeiras palavras, desenvolvi a idéia de que o projeto e o desenho inter-relacionam-se no processo criativo da arquitetura $^{72}$.

No ano de 1967 os monitores tínhamos a nosso cargo o apoio direto ao aluno. Nossa função era fazer críticas, ou seja, entrávamos diretamente no processo educativo. Ferreira Centeno proibia-nos de usar a lapiseira para qualquer explicação, e o esforço para exprimirmo-nos verbalmente era constante. Aprendia-se a estruturar uma crítica com certa ordem, do geral ao particular e do particular ao geral, ao colocar mentalmente 'numa balança' os aspectos negativos e positivos, começando por apontar sempre os últimos para não desestruturar o aluno. Ganhava-se a experiência do diálogo com o aluno e através dele conseguia-se descobrir o caminho para ajudar a desbloquear, em muitos casos, e em outros simplesmente a proporção, ou o tratamento adequado do desenho para objetivos específicos.

Sobretudo, aprendia-se um método válido para o ensino do desenho à mão livre para o arquiteto, base que, enriquecida com minha própria experiência de vida e outras contribuições, fundamentou o método de ensino que atualmente utilizo no desenvolvimento das aulas.

Minha participação na construção do Taller Total iniciou-se no período em que era estudante da graduação, que vai até 1969, ano de minha formatura, tendo continuidade, como professora, de 1970 a 1975, ano em que fui afastada. Em 1984 fui readmitida, por meio de decreto do

\footnotetext{
${ }^{72}$ As atividades desenvolvidas no Laboratório de Pesquisa e Ensino de Ciências Humanas, da FE-USP contribuíram para aprofundar essas idéias, resultando no artigo 'Arte, desenho e percepção ambiental’ in Educação de jovens e adultos .Secretaria Municipal de Educação e Formação Profissional. Santo Andre.: 2000.
} 
Ministério da Educação da República Argentina; porém, minha opção pelo Brasil impediu-me de assumir esse cargo.

Considero importante estender-me neste momento sobre minha primeira experiência docente, como monitora, entre 1967 e 1968. Reaberta em 1967, a universidade tinha na resistência à ditadura a tônica de suas atividades. As cadeiras de Composição Arquitetônica eram questionadas pelos alunos, pelos próprios docentes, em esprcial pelo grupo de professores chefes de trabalho prático, jovens que traziam novos conceitos em arquitetura: as discussões no seio do CIAM, as posturas do Team- $X$, as idéias de Bakema e Van der Broek, Candilis, Josic e Woods; Alison e Peter Smithson, Aldo van Elick, Giancarlo de Carlo, o grupo dos Metabolistas, Yona Friedman etc. Enfim, as discussões na FAU-UNC mudavam de rumo. No lugar das idéias de F. L. Wright, Le Corbusier, Bauhaus, Aalto etc., outras posturas arquitetônicas ocupavam nossos debates e despertavam nossas inquietações, além das notícias do Maio Francês de 1968, que também impactaram nosso imaginário.

O tema Moradia de Interesse Social tinha sido proibido na FAU-UNC ${ }^{73}$. Porém, a reunião da União Internacional de Arquitetos em 1969 em Buenos Aires elegeu esse tema e se programou um concurso para estudantes. No ano anterior, como alunos da cadeira de Composição Arquitetônica IV, desejávamos participar da eleição do tema de projeto, reconhecer um usuário real. Queríamos uma prática profissional comprometida com a realidade. Houve profundas discussões, renúncias de docentes e finalmente ganhamos, com muita luta, o direito a participar daquele concurso, podendo projetar Moradias de Interesse Social.

\footnotetext{
${ }^{73}$ O Concurso para Estudantes de Arquitetura (1967-1968), cujo tema, 'Perspectivas para a habitação em Argentina', publicado na revista Summa número 13, indica que a proibição não era nacional, já que participaram, entre outros, estudantes da UBA (Buenos Aires) e da Escola de Arquitetura da Universidad Nacional del Litoral.
} 
Outro aspecto importante era a influência de correntes arquitetônicas de outros países, sobretudo nas discussões sobre a relevância do projeto como processo e sobre a necessidade da Metodologia como ferramenta fundamental para a sua produção.

Em maio de 1969, em Córdoba ${ }^{74}$, irrompeu uma insurreição popular, o Cordobazo, gestada como resposta à repressão à sociedade, que criava forte descontentamento em muitos setores sociais. O Cordobazo foi uma revolta operário-estudantil com importante repercussão nacional. Considerado um marco histórico e identificado como o início do fim do governo de Onganía ${ }^{75}$. Nesse contexto realizei, em equipe com Sonia Filoñuk e Alberto Viroglio, sob orientação do professor e arquiteto Ricardo Veteri ${ }^{76}$, o trabalho final (tese), cujo tema, Moradia de Interesse Social - Conjunto Habitacional, atendia às normas do concurso para estudantes da UIA 69.

Esse projeto debatia, entre outras coisas, a contradição entre 0 alto nível de desenvolvimento das técnicas e suas aplicações. Por um lado, a técnica permitia a conquista da lua e invenções de armas sofisticadas para a guerra, e por outro lado, não era aplicada para satisfazer as necessidades de habitação, transporte, cultura, lazer, saúde etc. das grandes maiorias, contradição que permanece atual.

Considero pertinente, como esclarecimento, lembrar as palavras de Giancarlo de Carlo em 1968, revisando as conseqüências da Declaração CIAM (1928 - Frankfurt):

\footnotetext{
${ }^{74}$ A cidade de Córdoba cresceu significativamente entre 1945 e 1966, com um aumento populacional de 51\%. A área metropolitana alcançava em 1970 mais de 850 mil habitantes. Para isso contribuiu, entre outras coisas, o estabelecimento de duas indústrias automobilísticas: Ika Renault e Fiat, levando à cidade um impulso desenvolvimentista, segundo Martinez, Silvia, 2000: 68, apud Delich, F.

${ }^{75}$ Martinez, Silvia A., 2000: 85. Também Elkin, Benjamim,2000. Sobre o tema, ver F. Delich,, Crisis e Protesto Social. Córdoba, UNC,1969.

${ }^{76}$ Segundo declarações de Miguel Pereira, em entrevista concedida à autora em 2006, ele conheceu o arquiteto Ricardo Veteri em viagem realizada a Córdoba por ocasião de um congresso, tomando conhecimento do processo do Taller Total e tentando, na medida do possível, levá-lo para a FAU UnB, de Brasília durante sua gestão como diretor.
} 
"[...] depois do congresso vemos que aquelas propostas têm-se convertido em casas, bairros [...] cidades inteiras, manifestações palpáveis de um abuso contra os pobres, primeiramente e logo, com os não tão pobres [...] encobrindo culturalmente a mais feroz especulação econômica e a ineficiência política. Porém, estes 'porquês' tão alegremente esquecidos em Frankfurt ainda têm dificuldade de sair abertamente à superfície. Ao mesmo tempo, temos o direito de perguntar 'por que' a moradia deve ser tão barata como resultante possível [...] porque ao contrário de fazer todo o esforço para reduzi-las ao mínimo, os níveis de superfície, espessuras e de materiais, não tratamos de fazê-la espaçosa, protegida, isolada, confortável, bem equipada, rica em oportunidades para a intimidade, a comunicação, o intercâmbio e a criatividade pessoal. Na verdade, ninguém pode ficar satisfeito com uma resposta que apele para a escassez de recursos disponíveis, quando todos sabemos quanto se gasta em guerras, na fabricação de mísseis e sistemas antibalísticos, em projetos lunares, na pesquisa para o desmatamento das selvas habitadas por guerrilheiros e para a paralisação dos manifestantes que saem dos guetos, na persuasão subliminar, na invenção de necessidades artificiais, etc..." ${ }^{\prime 77}$.

O Congresso da UIA em 1969 permitiu aprofundar essas questões, buscar caminhos alternativos por meio de debates que discutiam os problemas habitacionais para as grandes massas. Entre as atividades desse Congresso destacou-se a palestra de Van Eick e a oficina dos arquitetos cubanos mostrando suas experiências com pré-fabricados in loco.

Em 1970, fui convidada com outros colegas pelo diretor-interventor da FAU-UNC, arquiteto Juan C. Fontán, para colaborar com a equipe docente do Taller Total de Composición Arquitectónica, anterior ao Taller Total.

${ }^{77}$ Carlo, Giancarlo de, apud Frampton, Kenneth ,1983: 282-283. 
Conforme Elkin, naquele momento anterior ao Taller Total, estudantes e professores questionavam e desejavam aprofundar conteúdos sobre as bases humanas e sociais da arquitetura, com maior conhecimento sobre teorias da arquitetura ${ }^{78}$. Também visualizávamos a necessária contribuição de outras disciplinas como respaldo, complemento, informação, método. Como se procuravam novas formas de ensinar e aprender arquitetura, sentia-se que só uma mudança real no ensino poderia dar sentido ao estudar e aprender para elevar a qualidade de vida dos homens. Essas expectativas e interrogações traziam a necessidade de auxílio, sem muita clareza de onde buscá-lo.

Foi nesse sentido que, no início de sua gestão, o diretor-interventor J . C. Fontán procurou subsídios fora da FAU-UNC. Para conseguir concretizar o Taller Tota/ de Composición Arquitectónica, buscou apoio na Escola de Ciências da Educação da Faculdade de Filosofia e Letras da UNC, decisão caracterizada por muitos como histórica. Os docentes provenientes de ambas as faculdades, ou seja, Arquitetura e Ciências da Educação, ao se aproximarem, paulatinamente, fizeram germinar inquietações que facilitaram o crescimento individual e coletivo de alunos e professores ${ }^{79}$.

A equipe de pedagogas, que levavam também idéias de Paulo Freire, teve a coragem de aceitar desafios, trabalhando diariamente junto aos docentes da FAU-UNC com modesta e inquebrantável força de vontade e com a mente aberta para escutar, sem preconceitos, quem falava. Era um momento no qual as velhas receitas já não serviam, e era preciso encontrar, com criatividade, outros caminhos. E a equipe de Pedagogia mostrou a importância de ter objetivos claros para iniciar a difícil tarefa das mudanças no ensino de arquitetura.

Como ressalta Elkin, os docentes arquitetos tínhamos uma falta total de formação pedagógica. Para alguns era conveniente ficar fechados nas

\footnotetext{
${ }^{78}$ Elkin, B.; 2000: 50.

${ }^{79}$ Ibid.: 51.
} 
disciplinas, continuando com uma visão descontextualizada da arquitetura, isolada da produção cultural, social e econômica, sem época histórica. Eram os que acreditavam que a arquitetura é uma amostragem simples e cheia de graça da beleza que o homem deixa em sua passagem pelo mundo ${ }^{80}$.

Desse modo, pode-se dizer que a tarefa cotidiana do Taller Total teve muitos tropeços até previsíveis. Mudar os rotineiros e tradicionais modos de ensinar arquitetura não é tarefa simples: houve resistências e, é claro, essa transição foi bem difícil. Ainda assim, a FAU-UNC viveu um tempo rico e profundo não só em idéias, mas também em atividades, ao incorporar a discussão de pessoas com ideais e propostas diferentes, inclusive opostas, mas com um objetivo comum: construir um ensino de arquitetura de qualidade.

No contato com os docentes não arquitetos, vindos de outras áreas, sobretudo das ciências sociais, muitas equipes de trabalho enriqueceram sua visão de arquitetura, sem modificar a especificidade de suas disciplinas, somando conhecimentos e cultura.

Em 1971, participei de concurso integrando-me ao Taller Total, como professora assistente, na área cultural. Meu perfil era considerado de 'professora de projeto', o que incentivou o diretor e outros colegas mais experientes a sugerir minha participação nesse concurso com a idéia de que "alguém de projeto estivesse na história", o que revela a disputa entre as diversas áreas, representando, entre outras coisas, visões diferentes do ensino, como se verá adiante. Penso que a troca de conhecimentos foi muito frutífera, já que, apesar de curta, minha estadia nessa área revelou a importância, para projetar, dos referenciais históricos, entendendo os por-que-quando-como-onde, ou seja, sem nunca perder de vista o contexto histórico de cada projeto arquitetônico. Como diz Milton Santos, "ao oferecer um ensino fragmentado, ele será acrítico. Todo ensino que é separado da historia

\footnotetext{
${ }^{80}$ Ibid.: 52.
} 
não supõe crítica. Então, por mais que apareça como sendo renovador, ele é repetitivo" ${ }^{\prime 1}$.

Dentro da área cultural, na FAU-UNC, além das disciplinas de História e Teoria da Arquitetura, estavam também incluídos os conteúdos de Urbanismo, Antropologia, Economia e Sociologia, que se foram somando nos anos seguintes.

Esse contato com os professores das áreas de Ciências Sociais e de Urbanismo possibilitou maior abrangência ao conceito de arquitetura, para o que também contribuiu o curso de Introdução à Antropologia. A busca de subsídios na antropologia acontecia desde os anos 1960 no interior do $\mathrm{Cl}$ AM, em especial pelo arquiteto Aldo van Eick, integrante do Team $X$. $O$ debate de arquitetura dessa década teve grande influência em Córdoba nos anos 1970, com intensas discussões. O que não aconteceu em São Paulo, segundo Ana Claudia Barone e Ermínia Maricato, já que a hegemonia 'lecorbusiana' manteve-se forte na FAUUSP. A análise desse fato foge ao alcance desta pesquisa, porém podese dizer que tem correspondência com as diferentes relações de forças políticas nos movimentos populares vivenciados em cada país.

Esse ponto de vista foi a base que permitiu aprofundar e alargar a minha visão, para a construção de idéias sobre a dialética da percepção da paisagem urbana e do projeto.

Paralelamente, a criação da Federação de Associações de Docentes Universitários de Córdoba (Faduc), da qual fez parte a Associação de Docentes de Arquitetura e Urbanismo (Adau), possibilitou que pela primeira vez em Córdoba docentes universitários se assumissem como trabalhadores da educação, passando a coordenar as lutas com os docentes dos níveis primário e secundário, parte também das lutas contra a ditadura militar e por melhor qualidade de ensino.

\footnotetext{
${ }^{81}$ Santos, M. 1998: 16.
} 
Nas décadas de 1960 a 1970, a Bauhaus foi uma forte referência para a arquitetura e urbanismo e seu ensino, contribuindo para impulsionar as novas propostas, entre elas o Taller Total e a experiência da FAU-SJC objeto de trabalho desta pesquisa - nos anos 1970-76, que serão analisadas mais profundamente na parte III.

No próximo capítulo, também na parte III, serão abordadas -- como referência -- as relações entre arquitetura, urbanismo e seu ensino na República de Weimar: Ernest May, Hannes Meyer e a Bauhaus. 


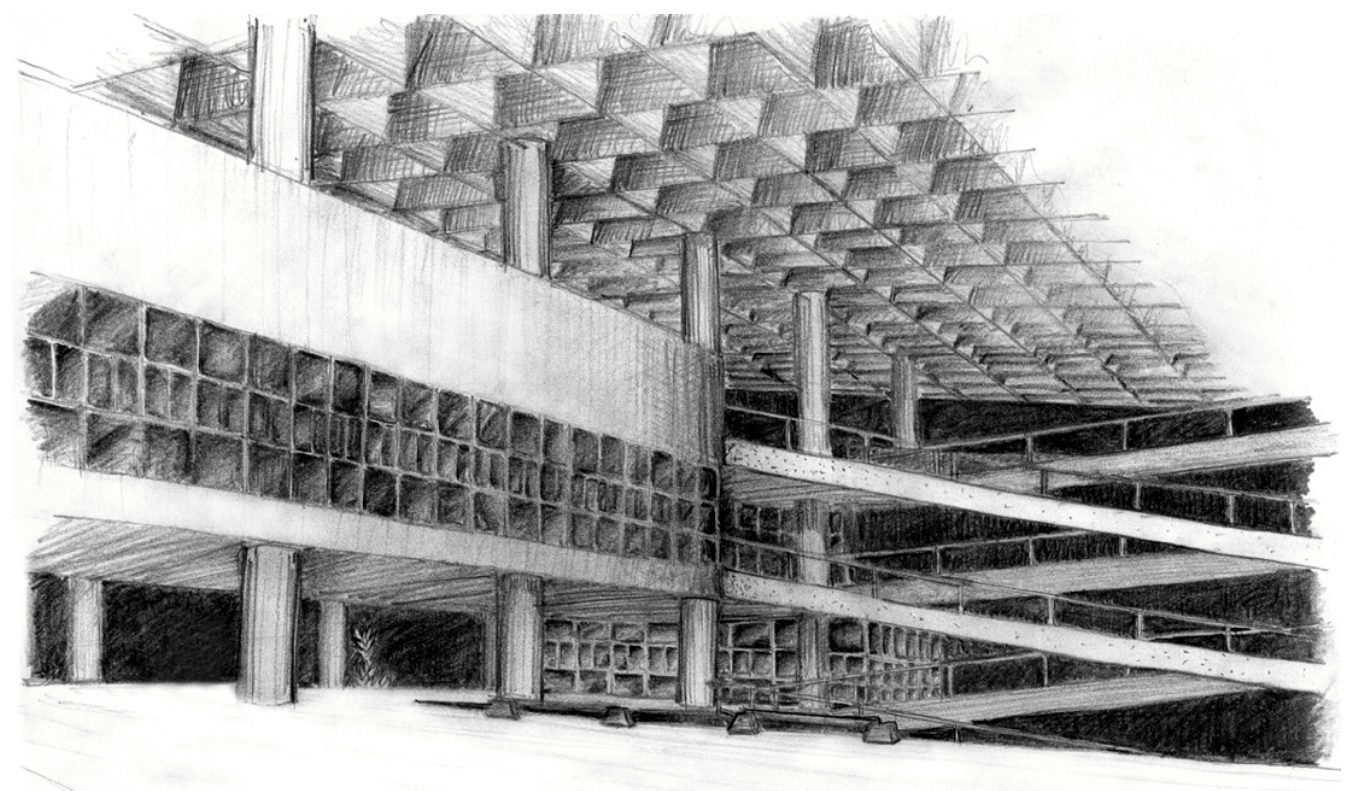

Edifício da FAU-USP na Cidade Universitária.

Desenho de Emilene Miossi, 1996. Arquivo pessoal da autora. 


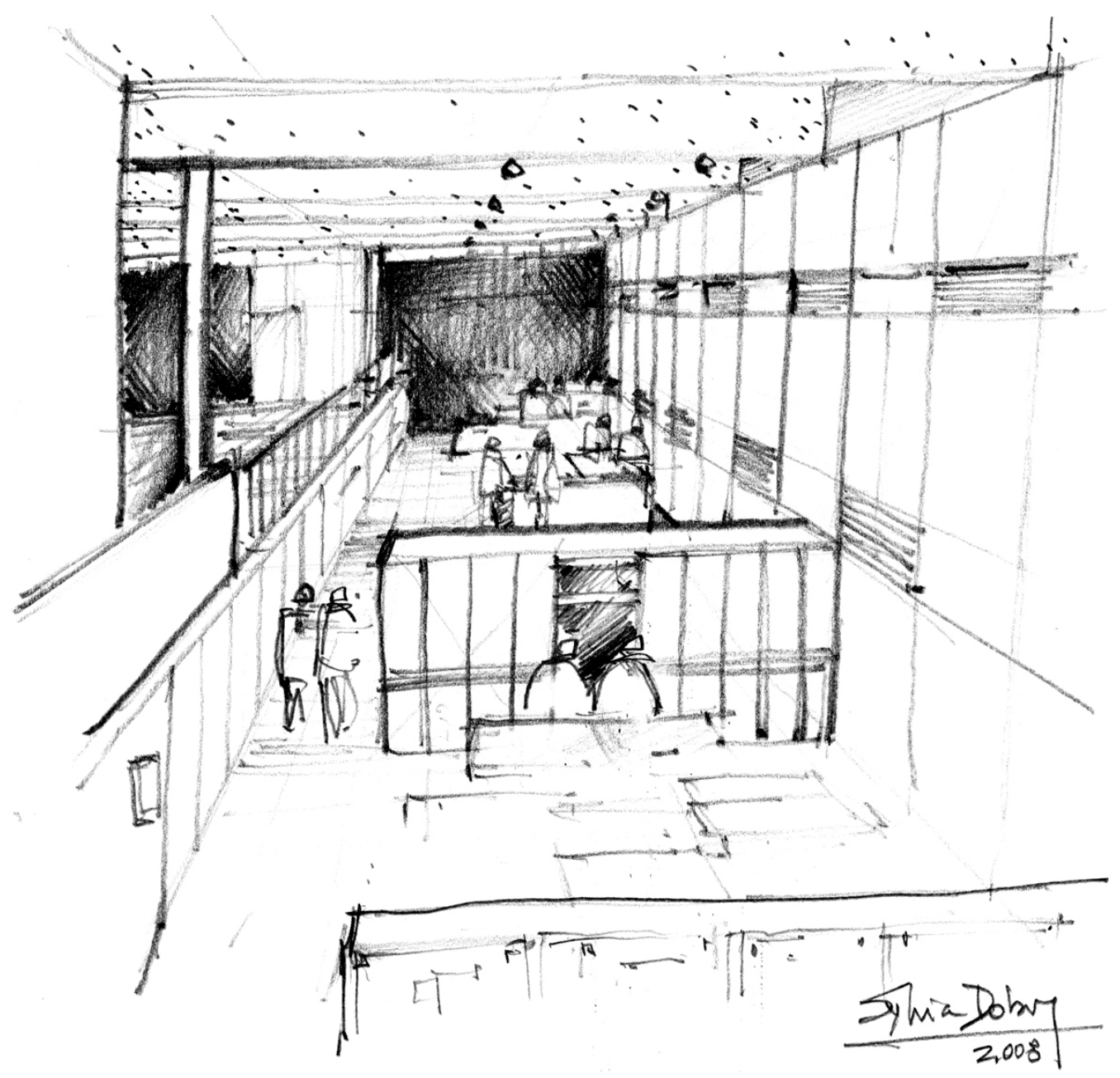

FAU-UNB, "Minhocão", salas de aula de diversos cursos.

Arquivo pessoal da autora. 


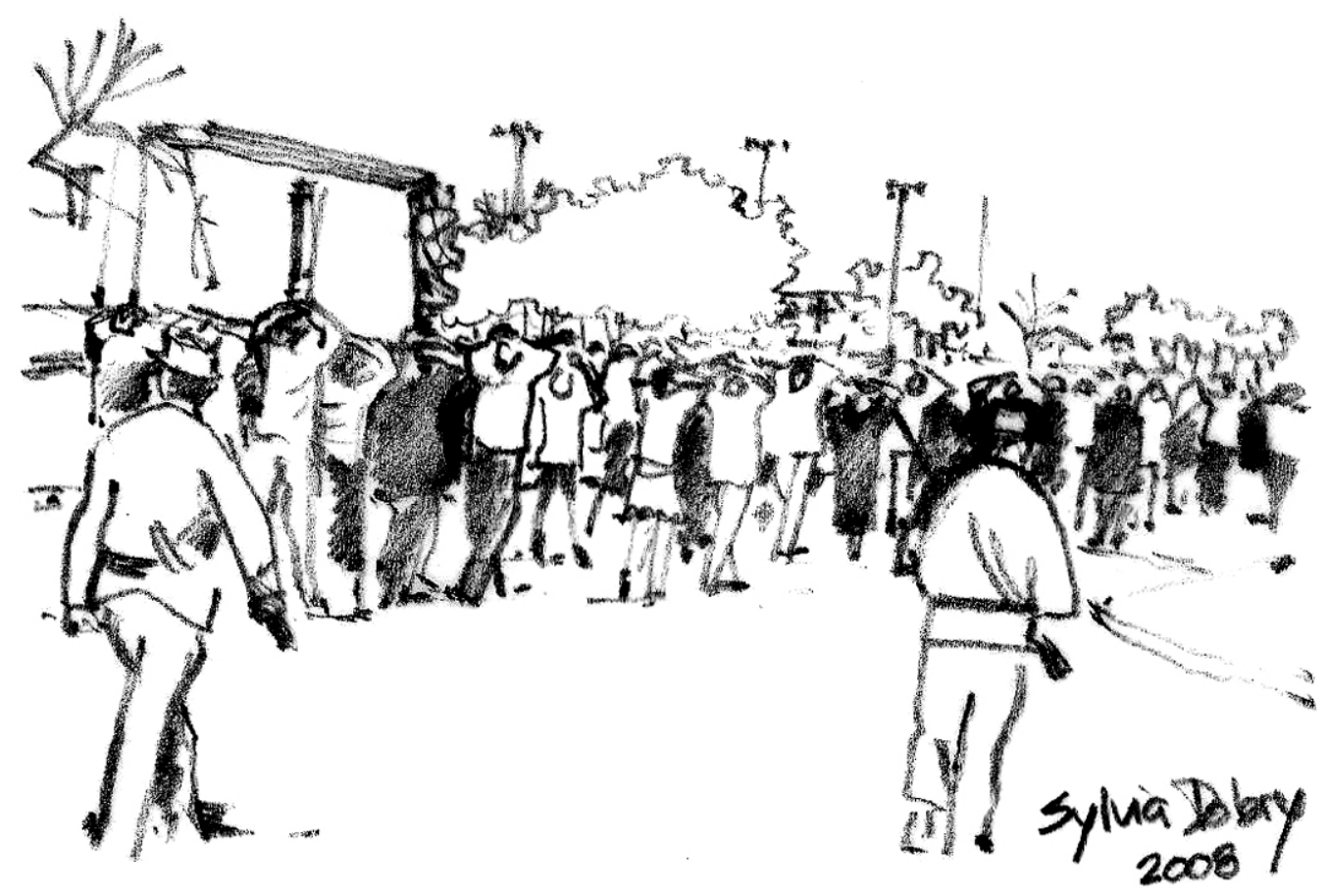

Invasão da UNB por uma operação conjunta de Exército, Polícias Militar, Civil e Política, em 1968.

Desenho realizado com base em fotografia publicada in www. arte.unb.br/ida_historia/65a70.htm, Do ICA ao IdA - Instituto de Artes Universidade de Brasília - De 1965 a 1970. 


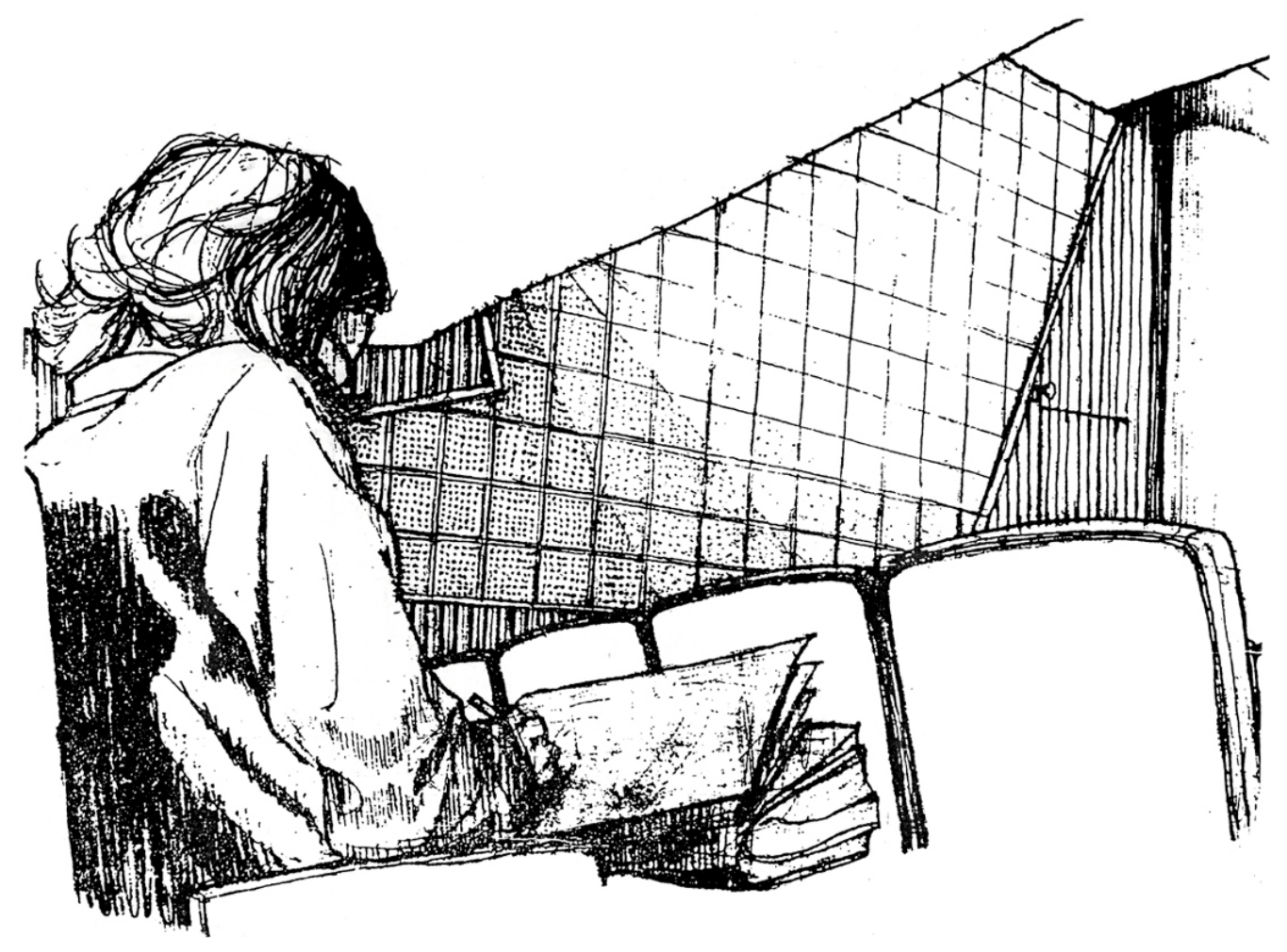

Auditório da FAU-UNC.

Desenho de Murina Kreiker, 1963, desaparecida durante a ditadura de 1976 na Arqentina. Publicado em FERREIRA CENTENO, Raul, 1973: 33. 
Parte III

PARA QUEM E COM QUEM: O ENSINO CRÍTICO E PARTICIPATIVO DE ARQUITETURA $\in$ URBANISMO

\section{Considerações iniciais}

Na década de 1970 a escola alemã Bauhaus era uma referência emblemática para o ensino de arquitetura e urbanismo. Também a FAU-SJ C, objeto de trabalho desta tese, retomava o debate sobre a experiência dessa escola. Por isso, este capítulo se propõe refletir sobre ela, focalizando o período da direção de Hannes Meyer, entre os anos 1928 e 1930. Será preciso analisar também, brevemente, o nascimento da escola, a importante presença de Walter Gropius, no contexto da República de Weimar (1919 a 1933), no qual se insere também a experiência de Ernest May e equipe em Frankfurt. Tentarei estabelecer as relações entre tais experiências: uma como expressão de ensino, outra como expressão arquitetônica e urbanística daquele momento histórico.

Para compreender com mais profundidade essa questão, considerei necessário elaborar previamente uma base teórica, remontando à diversidade de visões dentro do marxismo, com um recorte inicial no final do século XIX e as primeiras décadas do século XX. No que fui ajudada pela obra Pela mão de Alice - o social e o político na pósmodernidade, de Boaventura de Sousa Santos. 


\section{Capítulo I}

BAUHAUS, HANNES MEYER E ERNEST MAY

No segundo capítulo do livro, denominado "Tudo o que é sólido se desfaz no ar; o marxismo também?", Sousa Santos começa fazendo uma alusão à frase usada no Manifesto Comunista em 1848, por Marx e Engels. Naquele momento, meados do século XIX, ambos consideravam que o capitalismo e a modernidade continham em si mesmos um caráter revolucionário. 0 ritmo e a intensidade das transformações que se sucediam abalavam os modos de vida, inalterados por séculos, e os processos de regulação econômicos, sociais, políticos, até então julgados legítimos e naturais. Assim, a sociedade do século XIX, vertiginosamente, parecia se 'desfazer no ar'.

O Manifesto Comunista afirmava a radicalidade do capitalismo, vendo nele não só um novo modo de produção, mas também um momento importantíssimo da civilização: a modernidade, que "como tal, significava uma mudança paradigmática". Na visão de Boaventura de Sousa Santos, o Manifesto, ao mesmo tempo que critica duramente 0 capitalismo, celebra a modernidade.

Essa dualidade, no meu entender, comparece no discurso dos arquitetos modernistas, já no século XX, e explica a contradição entre 0 discurso revolucionário e crítico ao capitalismo, que eles fazem, e a suas práticas da arquitetura, convenientes para a produção capitalista ${ }^{1}$. Segundo o autor, a ciência, o progresso, a liberdade, a igualdade, a racionalidade e a autonomia são os elementos que englobam o projeto político, científico e filosófico da modernidade. Para Marx, esse projeto não poderia realizar-se no marco do capitalismo, só além dele.

\footnotetext{
${ }^{1}$ Tema desenvolvido em extenso por Hannes Meyer e por Otília Arantes, como se verá adiante.
} 
Por isso, o projeto econômico, filosófico e político de Marx residia em promover o passo que levasse a um outro sistema produtivo, ao socialismo, e logo ao comunismo, que poderiam realizar o projeto modernista, enquanto vigência plena de liberdade, igualdade, autonomia. Isso permitiria que os avanços da ciência e da técnica beneficiassem a humanidade e não só a minoria que usufrui do poder econômico, político, cultural.

Marx acreditava que a lei das relações de produção capitalistas que se instalava era uma lei de ferro e que sua superação estaria a cargo do movimento operário comunista.

Em seu livro, Boaventura de Sousa Santos descreve a história das estratégias, ora dos marxistas (em suas diversas correntes), ora dos defensores do capitalismo, para combater um ao outro.

\section{0-1920}

No que diz respeito à produção teórico-sociológica, Boaventura de Sousa Santos considera importantíssimo esse período, que culminou, em 1917, com a revolução socialista da URSS, e conceitua Marx como um dos fundadores da sociologia. A importância do marxismo se mostra até pelo fato de este ter começado a ser estudado em vários países, como na Universidade de Viena, por Carl Grunberg, que mais tarde seria o primeiro diretor do Institut für Soziale Forschung, onde se formou a Escola de Frankfurt, e na Universidade de Roma, por Antonio Labriola.

Iniciam-se também nesse período os debates entre as teorias de Marx e Weber, outro fundador da sociologia, debates que o autor considera paradigmáticos da sociologia contemporânea e que versavam sobre:

- as origens do capitalismo;

- o papel da economia na vida social e política;

- as classes sociais e outras formas de desigualdade social; 
- as leis de transformação social;

- o socialismo.

Nesse período, e não casualmente, a riqueza da reflexão marxista coincide com a grande pujança do movimento socialista. Este, com sua práxis, deu origem a duas cisões, uma política, a outra epistemológica, que se prolongam até os nossos dias.

A cisão política, que recebeu o nome de revisionismo, data de 1896 e tem seu expoente em Bernstein. Seus argumentos eram:

1. Que o marxismo como ciência deveria submeter-se à prova dos fatos e eles não iam no sentido previsto por Marx.

2. A miséria não tinha aumentado, e sim diminuído.

3. As classes não se tinham polarizado; pelo contrário, as classes médias cresciam.

4. O capitalismo parecia dispor de energias renovadas para superar suas crises, e estas eram cada vez menos severas.

Esses argumentos foram contestados por Rosa de Luxemburgo, Kautsky, Trotsky, Lenin e os austro-marxistas. A cisão epistemológica ocorreu a partir da crítica desses autores austro-marxistas Max Adler, Otto Bauer, Rudolf Hilferding e Karl Renner, que, influenciados pelo neokantismo e o positivismo de Ernest Mach, procuraram transformar o marxismo numa ciência empírica, uma sociologia das sociedades capitalistas. Em resumo: tinham uma concepção cientificista e sociologizante do marxismo².

Depois de 1917, essa concepção foi fortemente contestada por Karl Korsh, Lukacs e Gramsci, que, segundo Boaventura de Sousa Santos, coincidem na crítica de que, ao converter o marxismo numa ciência positiva, desarmava-se seu potencial revolucionário ${ }^{3}$. É impossível esquecer que as raízes hegelianas do marxismo o convertiam numa crítica filosófica, e da práxis, neste sentido orientada

\footnotetext{
${ }^{2}$ Santos, B. de S., 2003: 25, grifo nosso.

${ }^{3}$ Ibid.
} 
para a construção libertadora e emancipadora do mundo, antes que para uma análise sistemática e objetiva.

Hoje, essas tendências ainda se expressam: de um lado, na Escola de Frankfurt e, de outro, no marxismo analítico, de acordo com Sousa Santos.

\section{A República de Weimar}

A República de Weimar foi a resposta de uma Alemanha que saiu da Primeira Guerra Mundial fraca e humilhada. Primeira democracia parlamentar desse país, só durou quatorze anos, terminando com a subida dos nazistas ao poder. Foram quatorze anos efervescentes, em que se produziram idéias novas em todos os domínios ${ }^{4}$. Durante a República de Weimar, formou-se no interior da sociedade uma espécie de "contra-sociedade dentro da qual se podia nascer, viver e morrer; sociedade que tinha suas regras, seus costumes e seus modos de vida" ${ }^{5}$. Em todo o país se criaram cooperativas de consumo, de construção, de moradias etc. Um tecido de organizações mutuais e cooperativas acolhia os operários e demais pessoas necessitadas, protegendo-os e ajudando-os nos conflitos de suas vidas. Possibilitava 0 desenvolvimento profissional de seus membros, o crescimento intelectual, cuidados físicos e saúde. Essa educação promovida pelas citadas organizações abarcava assuntos diversos, desde questões de trabalho até educação sexual. Desenvolviam escolas políticas, escolas para aperfeiçoamento técnico, cultural, artístico, teatral, musical, poético, de dança, de esportes etc ${ }^{6}$.

Para entender melhor o contexto das experiências de arquitetura e urbanismo e de ensino citadas, considero interessante registrar a reflexão realizada por Hannes Meyer ${ }^{7}$, que divide em três fases o pós-

\footnotetext{
${ }^{4}$ Richard, L., 1988: 13.

${ }^{5}$ Richard,L., 1988: 54.

${ }^{6}$ Ibid: 54-55.

${ }^{7}$ Meyer, Hannes, (1935), 1972: 179.
} 
Primeira Guerra Mundial, na Alemanha, durante a República de Weimar:

1. Período da inflação (1919 a 1923)

2. Período da estabilização temporal (1923 a 1928)

3. Período da grande crise (1929 a 1934), com ascensão do nazismo e a segunda guerra mundial.

Os anos "que se seguiram à Primeira Guerra Mundial viram aparecer idéias, projetos sociais, correntes culturais e movimentos políticos", 8 que alguns dizem estar mortos, pois os problemas que desejavam resolver não mais existem. Na verdade, continuam sem resolução e "a 'modernidade', tal como concebida nos anos imediatos à Primeira Guerra Mundial é em muitos aspectos ainda a 'modernidade' de hoje" 9 . Ainda hoje não resolvemos "os problemas de habitação, da vida nas cidades, do lazer, dos transportes ou da localização planejada dos locais de moradia e trabalho [...] as relações sociais antagônicas [...] que se inscrevem no espaço e contribuem para modelá-lo"10.

\section{Período da inflação (1919 a 1923)}

Os horrores da Primeira Guerra Mundial, que deixaram em ruínas grandes regiões da Europa, provocaram também nos sobreviventes a esperança de uma vida melhor. "Em 1917 se produz a revolução bolchevique na Rússia, a Hungria vivencia uma revolução derrotada, a Alemanha vive uma situação pré-revolucionária, também inicialmente derrotada com os assassinatos de Rosa de Luxemburg e Karl Liebknecht [...] Esses fatos marcam profundamente as idéias e esperanças de grande parte do mundo, contribuindo para o que muitos reconhecem como a grande utopia que percorre o século XX"11. Nos países atingidos pela guerra, grande parte da população confia na

\footnotetext{
${ }^{8}$ Kopp, Anatole, 1990: 13.

${ }^{9}$ Ibid: 13.

${ }^{10}$ Ibid: 14.

${ }^{11}$ Pronsato, Sylvia A. Dobry 2005: 77.
} 
possibilidade imediata de transformações sociais, econômicas e políticas tendendo a um mundo melhor. É necessário lembrar que já desde muito antes da Primeira Guerra Mundial as condições de habitabilidade das moradias operárias, como também as da pequena burguesia, eram deploráveis. A maioria não contava com aquecimento, água corrente, tinha pouquíssimas possibilidades de penetração de luz e sol. Essa situação foi agravada com a guerra.

Segundo Hannes Meyer, as grandes flutuações econômicas, conseqüência do conflito bélico, expressaram-se em construções residenciais heterogêneas, tanto nos países que participaram da guerra como naqueles que se mantiveram neutros na Europa. Importantes obras de reconstrução se realizaram onde os efeitos da guerra foram mais evidentes. Ressurgem em "Flandres Belga, sul da França, sul da Itália, Polônia e Sérvia, milhares e milhares de novas moradias realizadas com capitais, materiais de construção, e inclusive mão-deobra provenientes dos países vencidos" ${ }^{\prime 2}$. Algumas vezes, nessas construções realizavam-se "tentativas de estandardização e tipificação da célula habitável e de seus elementos construtivos (como por exemplo no Plan Loucher, na França)"13.

Ainda na visão desse arquiteto, no período imediato após a Primeira Guerra não havia campo para a execução de grandes realizações arquitetônicas residenciais. Já desde o início do século XX, "as formas da cultura burguesa, que anteriormente haviam alcançado alto grau de aperfeiçoamento, eram demolidas uma atrás da outra", ${ }^{14}$ com 0 objetivo de adequar as residências e seus componentes à diminuição do bem-estar da grande massa consumidora. Atendendo a esse objetivo, inicia-se a simplificação das formas construtivas e da racionalização técnica, como também é levado em consideração o interesse intrínseco

\footnotetext{
${ }^{12}$ Meyer, H. (1935), 1972: 179.

${ }^{13}$ Meyer, H. (1935), 1972: 179.

${ }^{14}$ Ibid: 180 . Neste texto, caracteriza-se o início do século XX como o início da época imperialista.
} 
de aumentar a rentabilidade do capital imobiliário ${ }^{15}$. Sérgio Ferro mostrou compartilhar dessa visão quando afirmou, em palestra realizada no primeiro semestre de 2004 na FAU-USP: "A arquitetura cria valores econômicos, e isto é ignorado pela maioria dos autores que falam de arquitetura".

Paralelamente, descreve Hannes Meyer, alguns desejavam garantir os ganhos obtidos com a guerra: assim, tanto nos países vencidos quanto nos vencedores, a ameaça de desvalorização do capital, por causa do processo inflacionário, estimulava o investimento em bens sólidos, e arquitetos conceituados como os melhores da época, entre eles Muthesius (alemão), Moser (suíço), Hoffmann (austríaco), Horta (belga), Loos (tcheco), foram contratados para elaborar projetos de residências luxuosas (de alto padrão, como se diria hoje no jargão imobiliário). Assim, "os raros valores da arquitetura residencial se transformaram em fonte de lucro para especuladores e agentes da bolsa"16 diante da quase impossibilidade de "encontrar outras formas de investimento devido ao processo de formação dos Tesouros nacional e estrangeiro baseado no ouro, processo começado durante a Primeira Guerra Mundial"17.

Os ganhos derivados das atividades bélicas eram sujeitos a impostos. Para fugir deles, havia um recurso: investir esses ganhos em projetos sociais. Assim, grande parte deles foi aplicada na construção de moradias e instalações residenciais urbanas por entidades que assumiam a forma de 'cooperativas' ou de 'organizações para a prosperidade social'. A construção de moradias para operários, portanto, em última instância beneficiava as altas finanças. ${ }^{18}$ Também as cooperativas de consumo "escondiam uma parte de suas 'reservas silenciosas' acumuladas durante a guerra em cidades-jardins e

\footnotetext{
${ }^{15}$ Ibid.

${ }^{16}$ Ibid.

${ }^{17}$ Meyer, H. (1935), 1972: 180.

${ }^{18}$ Ibid.
} 
exemplares coloniais residenciais"19, entre outras: grandes conjuntos habitacionais (Siedlungem) da Cooperativa Förbundet, na Suécia; os conjuntos habitacionais da Wholesale Society, na Inglaterra; os conjuntos habitacionais do Verband Schweiz e, em parte, a Casa Popolare, na Itália ${ }^{20}$.

Hannes Meyer cita também, como exemplos de construções dessa época, os aglomerados residenciais do arsenal de guerra em Welwyn, perto de Londres; a fábrica de calçados Bata em Zlin, Tchecoslováquia; a fábrica Ford em Detroit, Estados Unidos; a empresa siderúrgica Krupp em Essen (Ruhr, Alemanha).

Para Meyer, essas construções expressam tendências heterogêneas, desde as românticas até as racionalistas; relaciona também 0 'classicismo ' das construções residenciais que floresce nessa época na Alemanha, na Suécia e na Escandinávia, com a época, “igualmente pobre em investimentos, das guerras napoleônicas"21.

Na Alemanha, as opressivas condições de vida das grandes massas populares e de setores da classe média contribuíam para a conscientização da necessidade de organização, tanto no plano sindical quanto no político ${ }^{22}$. Nesse contexto, segundo Koop, os arquitetos e urbanistas modernos iam além das formas e das técnicas ao tentar participar da transformação social. Em seus projetos eles levavam em conta fatores ambientais e sociais: tipo de solo, vegetação do entorno, equipamentos de sobrevivência, enfim, tudo o que tivesse relação com um novo conceito de 'habitar' ${ }^{23}$. Durante esses anos, acima das polêmicas entre grupos, havia-se formado uma unidade de intenções centrada na responsabilidade do arquiteto como agente do progresso

\footnotetext{
${ }^{19}$ Ibid.

${ }^{20}$ Ibid.

${ }^{21}$ Ibid.

${ }^{22}$ Koop, A., 1983: 32.

${ }^{23}$ Ibid: 25.
} 
social, muito embora essa unidade não se manifestasse no plano estético $^{24}$.

\section{A experiência da Bauhaus: durante o período da inflação}

A fundação da Bauhaus foi produto de um processo de vinte e três anos (de 1898 a 1919), no decorrer do qual se discutiram questões da educação da arte, sejam as compreendidas como belas artes, sejam a arte aplicada e o artesanato. Seu nome remete a Bauhutle, que significa corporação medieval de pedreiros ${ }^{25}$.

Walter Gropius foi nomeado seu diretor, tendo sido indicado, já em 1915, pelo arquiteto suíço Henry van de Velde para substituí-lo no cargo de diretor da Escola de Artes e Ofícios do Grande Ducado, em Weimar.

A criação da Bauhaus representou a vitória da linha de pensamento defendida por Gropius e outros artistas e arquitetos: uma educação baseada em ateliês, tanto para designers como para artesãos. Já outra linha de pensamento defendia que artesãos e artistas deveriam ser educados na Academia de Belas Artes.

Segundo A. J. Rodrigues, a Bauhaus foi a que "mais longe levou uma experiência de inovação. Esta [...] deve-se a um conjunto de professores que, muito embora com formações diversas, conseguiram uma transdisciplinaridade unida em torno de objetivos pedagógicos comuns $^{\prime 26}$.

Com contradições internas, é relevante a metodologia democrática e participativa com que a escola se organizou, demonstrando a possibilidade de "construir com vitalidade e riqueza, superando as

\footnotetext{
${ }^{24}$ Bruna, P., 2004, apontamentos de aula, disciplina AUH-5919-7, FAU-USP

${ }^{25}$ Frampton, K. 1983: 25.

${ }^{26}$ Rodrigues, A. J., 1989: 17.
} 
diferenças e concretizando uma síntese em que a pluralidade dos participantes fortaleceu o processo e enriqueceu a experiência"27.

A Bauhaus é complexa e contém "variantes muito diversas e concepções contraditórias que dão a esse movimento a sua riqueza de abordagens. Ela contém várias Bauhaus que dialogam e/ ou se contradizem, marcando um discurso cheio de nuances e até mesmo de conflitos $^{\prime 28}$.

Durante o período da inflação, pode-se considerar que a Bauhaus, localizada em Weimar (de 1919 a 1922), assumiu característica romântica ${ }^{29}$. Esse modelo defendia a criatividade, valorizava a intuição, 0 artesanato, o trabalho manual, a tradição, podendo-se distinguir duas vertentes: uma, que acreditava no 'dom' e na importância da tradição, e uma outra, em que se incluía a Bauhaus, que estabelecia uma estratégia profética de libertação da humanidade, anulando o elitismo de classe e contendo a um mesmo tempo características transgressivas e românticas. Estas, “longe de se confinarem a uma estratégia saudosista, apontam para uma ruptura radical do modelo social e econômico, apresentando-se com uma carga de modelo profético, anunciador de uma nova sociedade"30, porém sempre levando em consideração a dignificação do ser humano e uma melhoria social. Esse caráter romântico da primeira fase da Bauhaus convive nos ateliês com uma atividade permanentemente prática que "a conecta com a realidade, numa práxis que faz com que se transforme, de maneira superadora e complexa, o romantismo como habitualmente é entendido: o incentivo ao desenvolvimento da criatividade, que não exclui a intuição, mas que vê a construção de habilidades artísticas e perceptivas como produto de um processo e não como dom divino"31.

\footnotetext{
${ }^{27}$ Pronsato, Sylvia A. Dobry, 2005: 77.

${ }^{28}$ Rodrigues, A. J., 1989:17

${ }^{29}$ Segundo pesquisa sobre instituições de ensino de arquitetura realizada por GRANGE, 1997, apud Rodrigues, A. J., 1989:17

${ }^{30}$ Rodrigues, A. J., 1989: 17.

${ }^{31}$ Pronsato, Sylvia A. Dobry, 2005: 78.
} 
A gênese da Bauhaus é explicada pela atuação das várias correntes que se expressavam no interior da escola: desde grupos como a maçonaria, o mazdeísmo (do qual Itten fazia parte), a antroposofia, a teosofia, até movimentos de esquerda como, por exemplo, o Arbeitsrat fur Kunst (Trabalho para Arte) e o November Groupe, que se fundiram no Conselho dos Trabalhadores da Arte, que declarava, entre seus objetivos (em 1918), a proposta de uma nova obra de arte total a ser criada com a participação do povo. Em 1919 o Arbeitsrat fur Kunst, dirigido por Taut, Behne e Gropius, publicou um manifesto onde se reafirmava esta idéia: "Arte e povo devem formar uma unidade. A arte deixará de ser um luxo para poucos e a desfrutarão e experimentarão as massas. A meta é a aliança das artes sob a asa de uma grande arquitetura".

O manifesto elaborado por Gropius continha princípios que já haviam sido antecipados no programa arquitetônico de Bruno Taut para o Arbeitsrat fur Kunst, publicado em 1918. Nesse programa Taut defendia uma unidade cultural por meio de uma nova arte da construção na qual cada disciplina contribuiria para a forma final: "Não haverá fronteiras entre os ofícios, a escultura e a pintura... Tudo será uma coisa só: arquitetura" 32 .

A idéia de que há uma relação entre função e forma na arquitetura, fundamental para o movimento moderno, remonta a Vitrúvio. Para Alan Colquhoun, "no final do século XIX, o sentido atribuído à palavra função pelas diferentes disciplinas perdera grande parte de seu conteúdo idealista. [...] Segundo Ernest Mach, a noção de função devia substituir a de causa. Quando a ciência reúne vários elementos em uma equação, cada elemento torna-se uma função dos outros, a dependência entre os elementos torna-se recíproca, e a relação entre causa e efeito torna-se reversível" ${ }^{\prime 3}$.

\footnotetext{
${ }^{32}$ Frampton, Kenneth, 1983: 25-26.

${ }^{33}$ Colquhoun, Alan, 2004: 83, grifo nosso.
} 
A visão que reduz a Bauhaus ao funcionalismo não considera as contradições e complexidades de sua gênese. O clima que condicionava o ambiente cultural e a pedagogia dos primeiros anos da formação da Bauhaus, em que arte e artesanato estavam indissoluvelmente ligadas à arquitetura, está expresso no manifesto redigido por Gropius, em 1919:

“[...] arquitetos, pintores, escultores, devemos todos retornar ao trabalho artesanal [...] não há diferença essencial entre artista e artesão. 0 artista é um artesão enaltecido [...] em raros momentos de inspiração, que transcendem a vontade, a arte pode, inconscientemente, desabrochar do trabalho de suas mãos, mas a base artesanal é essencial para cada artista. Aí reside a primeira fonte de criatividade. Vamos, portanto, criar uma nova corporação do ofício dos artesãos, sem distinção de classes que levantem a barreira arrogante entre artesão e artista [...] não há professores e alunos na Bauhaus, apenas mestres, jornaleiros e aprendizes" ${ }^{34}$.

O texto está impregnado do clima do pós-guerra, no período da inflação. A guerra, com seus horrores, vista como catástrofe, junto ao clima pré-revolucionário, produziu uma ruptura nos valores culturais e sociais da Alemanha. As ilusões trazidas pela tecnologia no início do século se transformaram num pessimismo profundo. A técnica e as máquinas eram vistas nesse momento como mortíferas, destruidoras e como instrumentos da opressão ${ }^{35}$. Já para Giulio Argan, o pensamento de Gropius se mantém constantemente igual. Assim, em sua obra, Argan não aponta os diferentes momentos da escola Bauahus, que podem, no entanto, ser claramente diferenciados.

Logo após a Primeira Guerra, voltam à cena as idéias de William Morris $^{36}$, relativas à problemática da produção industrial na sociedade

\footnotetext{
${ }^{34}$ Manifesto da Bauhaus, Pronsato, Sylvia A. Dobry, 2005: 80.

${ }^{35}$ Pronsato, Sylvia A. Dobry, 2005: 80.

${ }^{36}$ William Morris (1834-1896), arquiteto, artista plástico, artesão, poeta e escritor marxista, organizou uma associação de artistas, com ateliê coletivo, objetivando a arte total.
} 
capitalista. Morris pensava numa arte de todos e para todos, sem preconceitos entre artistas e artesãos, tema retomado pela Bauhaus: a obra de arte expressa como totalidade através da arquitetura.

“A arquitetura abarca todo o ambiente que rodeia a vida humana; [... ] a arquitetura é um conjunto de modificações e alterações introduzidas na superfície da Terra [...] Cada um de nós deve assumir a vigilância e a responsabilidade da paisagem terrestre, com seu próprio estilo e suas próprias mãos na parte que lhe corresponde"37.

O manifesto da Bauhaus reafirma essa idéia. Contesta o modelo dominante e sinaliza uma estratégia para um novo modelo social. Defende a idéia de arquitetura com sentido ampliado, abarcando o espaço onde se realizam todas as atividades humanas: um habitat que contém desde os objetos de uso cotidiano, a casa, a paisagem, até o território em geral ${ }^{38}$.

Do ponto de vista didático, todos os professores valorizavam a prática dos ateliês, com a pesquisa e a investigação direcionando os trabalhos. No exercício da prática, a exigência de rigor era básica para a estratégia da escola. A orientação pedagógica baseava-se na criação orgânica, tentando "evitar toda rigidez, privilegiar a criatividade, libertar a individualidade, mas estudar com rigor" ${ }^{\prime 39}$, postulando total liberdade criativa. Entre as atividades didáticas produzidas nesse período, podese citar a Casa Somnerfeld, que documenta a didática da Bauhaus, primeira realização coletiva para a comunidade, primeiro passo na unidade de todas as artes, na visão de Argan, para quem essa experiência dispensa a marca de genialidade artística e reflete a relação entre trabalho artesanal e arte; a Casa teve a colaboração de muitos dos alunos da Bauhaus: Josef Albers (vitrais); J oost Schmidt (escultura

\footnotetext{
${ }^{37}$ Morris, William,( 1947): 246-248 apud Rodrigues, A. J., 1989: 35.

${ }^{38}$ Pronsato, Sylvia A. Dobry, 2005: 81-82.

${ }^{39}$ Rodrigues, A. J., 1989: 81.
} 
de madeira); Hans Jucher (ornamentos metálicos); Marcel Breuer (organização do mobiliário do edifício) ${ }^{40}$.

Até 1923 a Bauhaus manifestava uma profunda preocupação com 0 espaço no qual seria levantado o projeto. A técnica, contextualizada, resgatava as condicionantes geográficas, por exemplo, as referentes a topografia, resistência do solo, clima, necessidade de utilizar materiais do lugar. Essa preocupação se manteve nos anos posteriores, embora algumas vezes tenha sido relegada, por exemplo, quando se criaram modelos padronizados a partir de 1924, como se verá adiante ${ }^{41}$.

\section{As experiências de Ernest May e Hannes Meyer durante o período da inflação}

Para entender melhor as relações entre arquitetura e ensino de arquitetura nesse período me parece necessário fazer um breve paralelo entre Ernest May e Hannes Meyer, tentando compreender a evolução das idéias nas contradições do processo histórico.

Os dois arquitetos nasceram no fim do século XIX. O primeiro em Frankfurt, o segundo em Basiléia. Ambos realizaram viagens de estudo a Londres e ambos, possivelmente sem se conhecer, estabeleceram contatos profundos com o Movimento Cidade Jardim.

Entre 1910 e 1912 Ernest May trabalhou em Londres, no Departamento de Planejamento da Prefeitura, na equipe de sir Raymond Unwin e Barry Parker, pertencentes ao Movimento Cidade Jardim (que, no Brasil, se expressa no projeto dos bairros Jardim América e Jardim Europa, elaborados por Barry Parker durante sua permanência em São Paulo. Ernest May traduziu para a língua alemã o livro de Raymond Unwin, Town planning in practice. Novamente na Alemanha,, trabalhou, em Munique, no escritório de Teodor Fisher e Von Berlepesh, ardoroso

\footnotetext{
${ }^{40}$ Pronsato, Sylvia A. Dobry, 2005: 86-87.

${ }^{41}$ Ibid.
} 
promotor de bairros do tipo cidade-jardim ${ }^{42}$. De 1919 a 1924, após a guerra (da qual participou), desenvolveu em Breslau experiências urbanísticas que serviram de base, como se verá adiante, para seu trabalho em Frankfurt. ${ }^{43}$

Hannes Meyer pertencia a uma família com longa tradição no trabalho arquitetônico. Viveu, dos 9 aos 14 anos, na Basiléia, onde trabalhava nas horas livres como aprendiz de marceneiro. Aos domingos, copiava os projetos de jóias do pintor renascentista Hans Holbein, atividade que, conta ele no artigo 'Minha maneira de trabalhar'44, iniciou sua educação quanto à forma. Considero interessante, para analisar os temas propostos neste capítulo, conhecer a visão desse arquiteto sobre seu próprio desenvolvimento profissional: "Entre os 15 e os 18 anos trabalhava de dia como pedreiro. De noite freqüentava a escola profissionalizante; e avançada à noite e aos domingos copiava ininterruptamente a obra de Viollet-Le-Duc sobre o castelo gótico de Pierrefonds. Desenhei, além disso, em mais ou menos 40 horas, detalhes de trabalhos em pedra de Notre Dame de Paris. Estou convencido de que meu trabalho [...] foi facilitado pelo fato de ter estudado [...] as obras clássicas do gótico, porque dessa maneira eduquei meu sentido construtivo. Em 1913 morei um ano na Inglaterra com o objetivo de estudar os clássicos do urbanismo inglês; ${ }^{45}$ durante minha permanência nesse país analisei e reproduzi em escala grande parte da cidade de Bath, famosa por seus edifícios românicos, góticos e barrocos. Esse estudo permitiu-me conhecer as obras de alguns discípulos de Palladio, [...] e assim entrei em contato também com as teorias do espaço de Palladio. À idade de 27 anos, no entanto, adquiri ampla experiência sobre aglomerados urbanos, trabalhando a serviço de uma grande indústria [...] alemã, desenhei nas horas livres todos os projetos de Palladio, [...] em escala única As teorias de Palladio me

\footnotetext{
${ }^{42}$ Bruna, Paulo, 2004, apontamentos de aula, disciplina AUH-5919-7 (FAU-USP).

43 Panerai, Philipe R.; Castex, Jean; Depaule, J. Charles, 1986: 109.

${ }^{44}$ Meyer, Hannes (1933) 1972: 143.
} 
incitaram, nos anos 1919-1921, a realizar meu primeiro trabalho de urbanismo, o bairro satélite de Basiléia, Friedford, que foi encomendado pela União Central Suíça das Cooperativas (V.S.K.), com base em um módulo unitário de ordem arquitetônica. Todos os espaços exteriores (praças, ruas, jardins) e todos os locais públicos (escolas, restaurantes, comércios e salões de reunião), em decorrência deste sistema modular, sujeitaram-se a uma disposição artística que devia ser sentida pelos habitantes do novo bairro, como um conjunto de harmonias proporcionais de espaços" ${ }^{46}$.

É importante destacar que esse texto, elaborado em Moscou em 1933 (no momento em que, na Alemanha, a Bauhaus era fechada pelo nazismo já no poder), parece fazer parte de sua discussão com o realismo stalinista. Adiante, no mesmo texto, Hannes Meyer afirma: "Atualmente realizo uma nova incursão no campo dos sistemas construtivos clássicos e antigos, já que sinto uma atração pelo problema da 'expressão nacional' na arquitetura socialista. Porém, eu teria cometido um grave erro se, durante minha atual colaboração na futura capital do nosso estado autônomo israelita, Birobidshan, reproduzisse os planos para a reconstrução da antiga Jerusalém".

Durante os anos em que Hannes Meyer trabalhou nas fábricas de aço Krupp, de Essen, desenvolveu, entre outros projetos, o Siedlung Margarethenhöhe (1916) em colaboração com o arquiteto G. Metzendorf. "A implantação geral da Siedlung revela a forte influência provocada pelo contato com as realizações do movimento inglês das cidades-jardins, com o que Hannes Meyer, durante seus primeiros anos de atividade, parece particularmente relacionado". ${ }^{47}$

\footnotetext{
${ }^{45}$ Naquela viagem, Hannes Meyer entrou também em contato com as cooperativas de Londres e Birmingham.

${ }^{46}$ Entre os anos 1915 e 1918, Hannes Meyer trabalhou na oficina técnica encarregada de projetar as instalações residenciais das Fábricas Krupp de Essen. No artigo "Experiências de Urbanismo” (palestra realizada no México em 1938, falando dos projetos realizados para os funcionários dessa fábrica), testemunhou: "eu mesmo era empregado de uma construtora, sob o n 16824" (obra citada,: 191).

${ }^{47}$ Nota de Francesco del Co in Meyer, Hannes, 1972: 11, ilustrações.
} 
As experiências analisadas até aqui, datadas tanto dos anos da Primeira Guerra quanto do pós-guerra, nos anos da inflação, demonstram que existia, da parte dos arquitetos citados, responsabilidade social e compromisso com os problemas do seu tempo, expressos tanto nos seus projetos quanto na pedagogia da escola Bauhaus. A busca de uma estética, nesse período do modernismo, era parte de um longo processo de discussões, onde coexistiam diversas tendências.

Para Alan Colquhoun, “o experimentalismo' do movimento moderno tinha como propósito a libertação da arquitetura do dogma acadêmico. A teoria desse movimento moderno jamais afirmou que a arquitetura não era nada além de ciência e tecnologia. 0 que tal teoria afirmou foi que seu principal impulso deveria ser a abertura à realidade tecnológica e social”48.

Para que esse impulso acontecesse, ainda segundo Colquhoun, "foi necessário rejeitar totalmente as regras a priori da arquitetura" ${ }^{49}$. Só poderiam ser aplicadas à arquitetura "as regras do experimentalismo científico" 00 . Interessante destacar que "as regras da arquitetura correta estavam agora implícitas, não explícitas [...] cujo propósito era o de regular o sistema arquitetônico, não provê-lo de uma constituição" ${ }^{11}$.

\section{Período da estabilização temporal (1923 a 1928) ou da pseudo-conjuntura}

Segundo Hannes Meyer ${ }^{52}$, nesse período se afirmaram novas formas nas construções residenciais, resultado da tendência à industrialização da construção, da estandardização e tipificação dos elementos construtivos.

\footnotetext{
${ }^{48}$ Colquhoun, Alan, 2004: 189, grifo nosso.

${ }^{49}$ Ibid.

50 Ibid.

51 Ibid.

${ }^{52}$ Meyer ,Hannes, (1935) 197: 181.
} 
Os projetos desenvolvidos por Ernest May e equipe em Frankfurt se inseriam exatamente na tendência desse período, chamado de período da prosperidade econômica, durante a República de Weimar, experiência da qual falarei adiante.

Depois da crise monetária e política do primeiro período, as finanças alemãs se reorganizaram: cria-se o Rent Mark; regulamenta-se 0 sistema crediário ${ }^{53}$. A Alemanha passou a usufruir nesse momento dos benefícios que lhe possibilitaram os créditos e empréstimos do capital norte-americano. A dependência desse capital, posteriormente, trará más conseqüências à economia alemã.

Hannes Meyer caracteriza essa fase como a do "apogeu do capital monopólico, que com os métodos mais refinados de racionalização, utiliza o período da pseudo-conjuntura para incrementar a utilidade das rendas do solo aumentando assim o benefício derivado da exploração usurária das habitações" ${ }^{\prime 54}$. Prossegue, no mesmo texto: “Trata-se sempre de uma racionalização contra o nível de vida e o modus vivendi da ampla massa operária. Assistimos ao nascimento da moradia mínima e da moradia para o mínimo de existência [...] 0 número e a superfície dos locais de estar e de circulação diminuem gradualmente; projetam-se plantas sem circulação, sistemas de cabines para dormir, quartos divisíveis, etc. A cozinha-corredor se reduz gradativamente a cozinha, a pequena cozinha, a pequena cozinha de canto, até simples armário de cozinha".

Essas palavras, vindas de quem foi protagonista importante do movimento moderno, de ativa atuação como professor da Bauhaus e segundo diretor, após Gropius, surpreende por sua cáustica ironia. Nesse texto, escrito em fevereiro de 1935, ele expressa uma discussão que perpassa todo o modernismo e chega até nossos dias. Não nos esqueçamos também que se trata da visão crítica de sua própria atuação.

${ }^{53}$ Panerai, P.; Castex, J.; De Paule, J.C.; 1988: 107. 
No tema da cozinha parece evidenciar-se uma discordância com Gropius, referente à nova família, à superação na vida moderna da família 'ampliada'. A discussão desse tema, porém, supera os objetivos deste trabalho.

Hannes Meyer vê positivamente, ainda no mesmo depoimento, o fato de as "instalações técnico-sanitárias das moradias terem um nível muito mais alto", ressaltando que "cada moradia está provida de instalações hidráulicas para água quente, calefação e instalações tanto elétricas como de gás". Destaca também a importância do nascimento de novas tipologias, como a habitação com galerias, na qual um sistema de construção de quatro andares possibilita unir até 30 unidades com uma mesma escada, e o desenvolvimento de tipologias em linha, em que a tendência à estandardização e à racionalização revela-se com mais clareza.

A visão de Meyer sobre a arquitetura da República de Weimar (e de outros países, naqueles anos) é relevante porque provém de um arquiteto que vivenciou, com total entrega e responsabilidade social até o fim da sua vida, a época histórica na qual foi protagonista ativo e consciente.

Ele e Ernest May foram dos primeiros a entender o que realmente estava acontecendo na Alemanha, enxergando além das mistificações e esse discernimento se relacionava a uma prática comprometida com 0 desejo de resolver os graves problemas da época, no âmbito da arquitetura e do urbanismo.

Na análise dos textos de Hannes Meyer, para uma compreensão precisa e não literal, devem ser levadas em consideração as datas em que foram escritos. Eles refletem valores frente a cada situação e momento histórico, sobretudo no que diz respeito ao significado da arte e da ciência para a época e, em particular, para o próprio Hannes Meyer.

\footnotetext{
${ }^{54}$ Meyer, H., (1935) 1972, : 182.
} 
A arquitetura da época em geral abdicava de uma atitude subjetiva essencialmente preocupada com aspectos estéticos (Academia de Belas Artes) para substituí-la por preocupações científicas. É importante lembrar que até um artista plástico como Kandinsky, em seu livro Ponto e linha sob o plano, se propõe criar uma ciência da arte. Cabe aqui ressaltar que, segundo Colquhoun, os valores estéticos não eram explicitamente assumidos, na época, por Hannes Meyer, entre outros arquitetos, mas que de fato sempre existiram; ou seja, as regras da arquitetura correta, enquanto estética, estavam implícitas ${ }^{55}$ na própria prática da arquitetura.

Essa atitude, porém, não era homogênea: por exemplo, em Viena permaneciam as preocupações estéticas a priori. Meyer diz que "nos anos 1923-1930 se constroem, por iniciativa da administração municipal da social democracia, 43.000 novas habitações populares. Edificadas em volta das chamadas Wohnhöfe, desde o ponto de vista arquitetônico, aparecem acabadas com cuidado, e localizadas circularmente ao redor da periferia da capital ${ }^{\prime 56}$. É importante agora nos determos nas atividades de Ernest May e equipe em Frankfurt, representativas como expressão da arquitetura e urbanismo desse momento histórico.

\section{Ernest May e equipe em Frankfurt}

Frankfurt, cidade industrial importante na Alemanha, expandiu-se, desde o século XIX, em bairros periféricos "conforme traçados que demonstram a herança haussmaniana: edifícios para o estamento burguês localizados junto aos passeios e avenidas e Miel-kazerne compostos por exíguas habitações para a classe operária". ${ }^{57}$ Com 0 apoio das leis Adiekes (1902), que davam às municipalidades a

\footnotetext{
${ }^{55}$ Colquhoun, Alan, 2004: 189.

${ }^{56}$ Meyer, H. (1935) 1972: 182.

${ }^{57}$ Panerai, P.; Castex, J.; De Paule, J.C., 1988: 109.
} 
possibilidade de adquirir terrenos e influenciar no mercado imobiliário, tentou-se limitar a grande especulação que imperava.

Os primeiros anos da República de Weimar foram turbulentos. Duas obras de arte registram esses anos: o Monumento aos mortos de março, realizada por Gropius em 1921, em Weimar, em homenagem aos assassinados pelos direitistas durante o putsch de Kapp em 1920, e - Monumento a Karl Liebknecht e Rosa de Luxemburgo, realizado em Berlim em 1926, por Mies van der Rohe, homenageando esses teóricos e ativistas de esquerda e lembrando seu assassinato em junho de 1919.

O movimento operário conservava ainda o poder e os sindicatos estavam organizados. As fortes pressões exercidas sobre a prefeitura social-democrata tiveram o efeito de apressá-la a colocar como meta "a realização de um grande número de conjuntos habitacionais, com a prestação dos meios técnicos e imobiliários necessários"58, impulsionando a construção de habitações sociais e a tentando solucionar grande parte dos problemas urbanos. Falar em meios técnicos inclui a organização do Serviço de Arquitetura e Urbanismo, colocado sob as ordens de Ernest May com atribuições que superavam as tradicionais (definição de esquemas e controle de obras), devendo ele participar das decisões da política urbana do município. Construiu-se grande número de conjuntos habitacionais com pré-fabricação pesada, mobiliário industrializado etc. As iniciativas de Ernest May e equipe colocaram Frankfurt em uma posição de liderança naquele período. Quanto ao planejamento da paisagem urbana, o arquiteto propôs uma divisão para a cidade, mantendo o centro histórico, que remontava aos romanos. No mesmo período Le Corbusier, no congresso CIAM, realizado em Frankfurt em 1929, propôs o plano Vila Radieuse, uma evolução do Plano Voisin, de 1925, que pretendia a demolição do centro histórico de Paris. Duas propostas antagônicas, que confirmam que o CIAM não era homogêneo, conforme o arquiteto e professor

${ }^{58}$ Ibid. 
Paulo Bruna. Na proposta de May, a cidade operária seria uma cidadejardim fora de Frankfurt.

A partir de sua nomeação, May concentrou-se em elaborar um programa de obras de médio e curto prazo, um plano diretor de conjunto e os planos parciais para as primeiras atuações, que tiveram início um ano após iniciada sua gestão.

No curto intervalo de três anos (1926-1928) foram construídas quase 8.000 moradias sociais. Um segundo programa, de 1928, propôs a construção de mais 16.000 unidades no prazo de três anos. A elaboração desse programa estava incluída no Plano Diretor de Frankfurt, que fixava as localizações possíveis tanto das habitações como das áreas industriais e espaços verdes. Isso revela o surgimento de uma nova idéia que, modificando a relação entre o público e o privado, ao mesmo tempo conscientizava-se de que da habitação também fazem parte os equipamentos e serviços coletivos, e não só a casa. Dessa maneira, criou-se uma forte relação entre arquitetura e urbanismo ${ }^{59}$.

Os princípios do Plano Diretor continuavam essencialmente aqueles que orientaram o plano de expansão de Breslau, realizado por May de 1921 a 1924: recusa de perpetuar o desenvolvimento radio-concêntrico e vontade de introduzir áreas verdes que poderiam controlar 0 crescimento urbano $0^{60}$. A idéia do desenvolvimento expansivo se relaciona com sua anterior experiência inserida nos critérios de cidadejardim, com Unwin, sobretudo a realizada em Hanstead. As moradias, organizadas em conjuntos (Siedlungem), diferem das projetadas por Howard (inspiradas em aldeias autônomas de comunidades pastorais norte-americanas): são bairros de uma grande cidade industrial. As comunicações entre as habitações, os lugares de trabalho e os centros são articuladas por redes de transporte público. Os Siedlungem eram providos de equipamentos que visavam satisfazer as necessidades

${ }^{59}$ Bruna, P., 2004, apontamentos de aula, disciplina AUH-5919-7 (FAU-USP) 
elementares ${ }^{61}$. Ao penetrar no centro histórico, bondes articulados mergulham sob a terra.

May, embora criticasse o urbanismo do século XIX, tinha laços profundos com a história de Frankfurt, cujo centro foi objeto de seus cuidados, como, por exemplo, o projeto de recondicionamento dos passeios às margens do rio Main. As áreas de vegetação de terrenos agrícolas, hortas, bosques e parques públicos eram na sua visão um recurso para limitar o crescimento urbano. 0 exemplo de Romerstad (um dos Siedlungem), que evoca a origem romana, motivo de orgulho de Frankfurt, ilustra como May estabelece diálogos entre a cidade e sua zona de expansão ${ }^{62}$ : a muralha fazia um diálogo entre o recinto fortificado da cidade velha, o vale do rio Nidda e a periferia do século $X I X^{63}$.

“Em 1925, a periferia de Frankfurt chegava ao rio em mais que um ponto, na estrada de Hedderheim, deixando um extenso terreno livre entre a cidade e as aldeias. 0 trabalho de May consiste em dar forma e status a essas terras que se converterão em um parque público à imagem dos grandes parques londrinos e a cujo redor, as aldeias, unidas pelas siedlungem compõem uma coroa urbanizada... Jardins e avenidas modelam um sistema contínuo, independente da rede viária, que antecipa as teorias que trinta anos depois Le Corbusier aplicaria em Chandigarh." 64

Os primeiros conjuntos foram realizados por May dentro de uma linguagem plástica inserida na da cidade-jardim. Por exemplo, em Romerstad, ele adaptou o esquema de projeto às deformações formais para adaptá-lo à configuração do terreno e para diferenciar os bairros, segundo os princípios do pitoresco preconizados por Unwin.

\footnotetext{
${ }^{60}$ Panerai, P.; Castex, J., De Paule, J.C., 1988 : 113.

${ }^{61}$ Ibid.

${ }^{62}$ Panerai, P.; Castex, J., De Paule, J.C., 1988 : 113.

${ }^{63}$ Ibid.

${ }^{64}$ Ibid.
} 
À medida que os compromissos pressionavam e o período da crise se aproximava, as necessidades da pré-fabricação e da racionalização da construção passaram a prevalecer, substituindo o pitoresco pela linha reta.

\section{A Bauhaus no segundo período da prosperidade econômica}

Nessa época, a Bauhaus expressava preocupação com a idéia de produção seriada, em larga escala, que representa, como diz 0 arquiteto Bruna, um esforço coletivo e não uma idéia individual. Em fins de 1923-1924, a Bauhaus, ainda em Weimar, por circunstâncias relacionadas ao momento político e social, assumiu uma concepção marcadamente técnico-funcional. Isso se traduziu em uma mudança de currículos e professores que elaboraram programas adequados ao novo perfil da escola. 0 modelo de escola técnico-funcional ${ }^{65}$ considerava a técnica e a indústria como fundamentais para o progresso e via no artista, mais que um criador, um engenheiro. De cunho positivista, valorizando a ciência, tinha caráter racionalista e experimental e estava permeada por princípios como: indústria a serviço da sociedade e da arte; investimentos e experimentação para procurar elementos inovadores na técnica e na indústria.

As propostas da Bauhaus em Weimar tinham em vista uma sociedade socialista, mas a revolução espartaquista, derrotada, desfez essas ilusões. A sociedade capitalista impôs a divisão técnica e social do trabalho, e os projetos com a participação do povo passaram a ser incorporados ao mercado: após 1923 a Bauhaus foi compelida a se integrar ao processo produtivo.

Ao pretender produzir objetos para o bem-estar das massas, não conseguiu fugir da lógica dos lucros e mais-valias que rege a sociedade de consumo. "Valor de uso ou valor de troca, eis o dilema com que se vai debater a Bauhaus. Esta bipolaridade sem que se resolva quem

\footnotetext{
${ }^{65}$ Segundo pesquisa sobre instituições de ensino de arquitetura realizada por Grange, 1977, apud Rodrigues, A.J., 1989: 17.
} 
produz e para quem se produz, cria ilusões, recuperações e contradições infindáveis"

O racionalismo da Bauhaus tinha uma forte preocupação social. Embora em Dessau a ênfase na formação de especialistas fosse maior, transparece em todas as experiências da Bauhaus a idéia de totalidade. A partir de 1924, a idéia de 'obra de arte total' foi sendo substituída pela de 'obra total'. Nesse mesmo ano Moholy Nagi introduziu 0 conceito de síntese funcionalista, que Gropius passará a desenvolver, relacionado ao trabalho de equipe. 0 conceito de diretor de orquestra correspondia ao de uma democracia na produção da arte.

Conforme Rodrigues, a Bauhaus é também condicionada por um plano estrutural que, atenuado pelos efeitos do pós-guerra, fez ressurgir em 1924 o modelo urbano-industrial do capitalismo, seu caráter social e tecnológico.

Na Alemanha anterior à República de Weimar, nas políticas de Guilherme II, já se identificava o ideário de uma potência que pretendia responder com a produção industrial às necessidades do capitalismo em expansão, fato que se expressava também no movimento arquitetônico, no design, no urbanismo, nas artes. Muitas vezes, foi dos próprios monopólios, por exemplo, a empresa AEG, que nasceram propostas de renovação, buscando um funcionalismo que ficará, contraditoriamente, a serviço de uma indústria interessada no produtivismo e na racionalização de tarefas. Assim, tanto a Bauhaus de Weimar, utopia do expressionismo, como a de Dessau, utopia do funcionalismo industrial, são reflexos do desenvolvimento da sociedade na Alemanha.

\footnotetext{
${ }^{66}$ Rodrigues, A.J., 1989: 20.
} 


\section{Hannes Meyer e a Bauhaus (1928-1930) ${ }^{67}$}

No período em que essa escola teve como diretor Hannes Meyer, progressivamente seu discurso social passou a ser mais radical, mesmo sem abandonar o campo técnico-funcional.

Isso trouxe algumas dificuldades, já que a sociedade alemã era uma das primeiras a acusar o embate da crise da bolsa nos Estados Unidos, devido à dependência do capital financeiro e, num momento prénazista, desejava neutralizar os conflitos sociais tentando apagar todo vestígio de conteúdo ideológico. A gestão de Hannes Meyer só pode ser entendida nesse contexto, em que forças conservadoras ganhavam terreno, ainda que existisse uma simpatia crescente pela Bauhaus. Nessa fase, realizavam-se pesquisas de campo sociológicas, que estabeleciam contato com organizações representativas da população, entre elas os sindicatos. Mudanças pedagógicas pioneiras foram realizadas: por exemplo, a forma pela qual os alunos mais jovens aprendiam com os mais experientes, que eram apoiados pelos professores; a participação de estudantes de arquitetura na construção dos edifícios do bairro de Tortem Dessau, em 1930, iniciada por Gropius.

No caso da Escola da Confederação Geral dos Sindicatos Operários Alemães, projetada e executada sob sua direção, os estudantes dos Ateliês e do Departamento de Arquitetura da Bauhaus participaram em todo o processo. Muito bem implantada, integra-se na paisagem do lago e da floresta. Os edifícios estabelecem uma relação exteriorinterior. Nessa obra, Hannes Meyer contradiz seus textos, afirmando um funcionalismo estritamente técnico, demonstrando cuidado na resolução plástica e forte sensibilidade à paisagem. Os métodos de ensino que aproximavam a Bauhaus da vida, da realidade sociopolítica ligada às necessidades populares, constituem as verdadeiras razões da demissão de Hannes Meyer, no período de férias de 1930, quando

\footnotetext{
${ }^{67}$ Esse tema foi desenvolvido com maior detalhamento em Sylvia A. Dobry Pronsato, 2005.
} 
estudantes e professores estavam ausentes. Em 1930, ${ }^{68}$ ele foi para a União Soviética, onde desenvolveu (1931-1936) diversos projetos, vários em colaboração com equipes de estudantes da Bauhaus.

Também Ernest May, percebendo a situação alemã com clareza, foi, em fins de 1930, para a União Soviética, onde, junto com a Brigada May, trabalhou em diversos projetos.

Quando se instaurou o Realismo Soviético nas expressões de arte, a maioria dos arquitetos modernistas saiu da União Soviética. Hannes Meyer voltou à Suíça em junho de 1936, onde permaneceu até 1938. Em 1939 foi convidado pelo presidente Lázaro Cárdenas para trabalhar no México, onde, entre outras funções, foi professor e diretor do Instituto de Urbanismo e Planificação. Em 1949 voltou à Suíça, onde faleceu, em 1954.

As experiências analisadas brevemente neste capítulo expressam 0 contexto histórico, sendo fruto, tanto no ensino da arquitetura quanto nas realizações arquitetônicas e urbanísticas, de uma consciência dos graves problemas que se tentava superar. É importante, no entanto, levar em consideração que, como diz Tafuri, no caso da República de Weimar, "os instrumentos urbanísticos na mão da social-democracia não são apetrechados para poderem intervir lá onde o capital privado tem todo o interesse em gerir diretamente" ${ }^{\prime 69}$.

A Bauhaus foi uma forte referência para as novas propostas de ensino de arquitetura e urbanismo nos anos 1960-1970 no mundo e na América Latina, entre elas a FAU-USP e a FAU-UnB, analisadas nos capítulos anteriores, e também o Taller Total de Córdoba, Argentina, e a FAU-SJ C - objeto deste trabalho - , no estado de São Paulo, Brasil, que serão tratados a seguir.

\footnotetext{
${ }^{68}$ CO, Francesco del, in Meyer, Hannes, 1972: 11.

69 Tafuri, M., 1985: 127.
} 


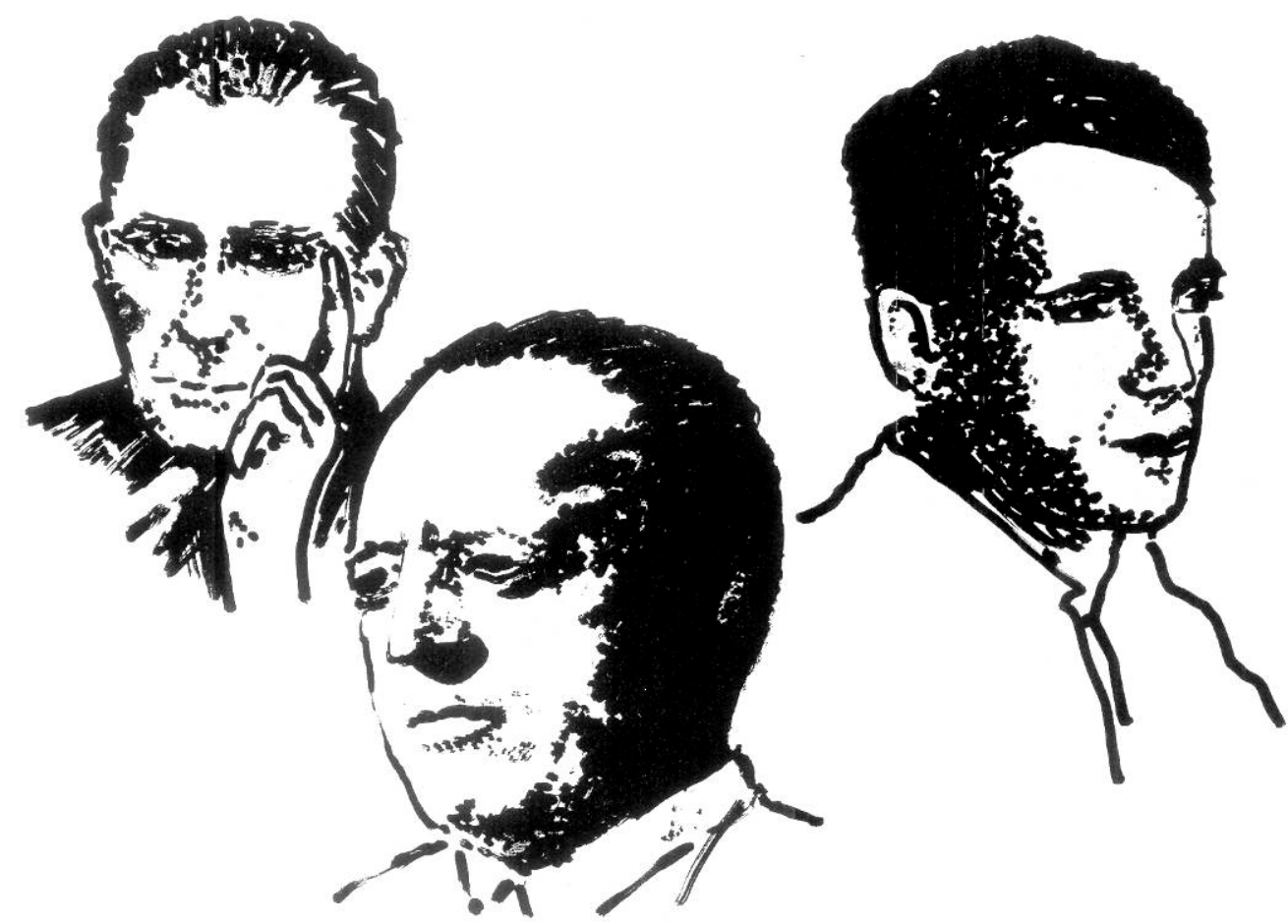

Da esquerda para a direita, Walter Gropius, 1을 Diretor da Bauhaus

(1919-1928); Mies Van der Rohe, 3o Diretor da Bauhaus (1930-1933) e Hannes Meyer, 2o Diretor da Bauhaus (1928-1930)

Desenho elaborado por Sylvia Dobry com base em fotografias. 


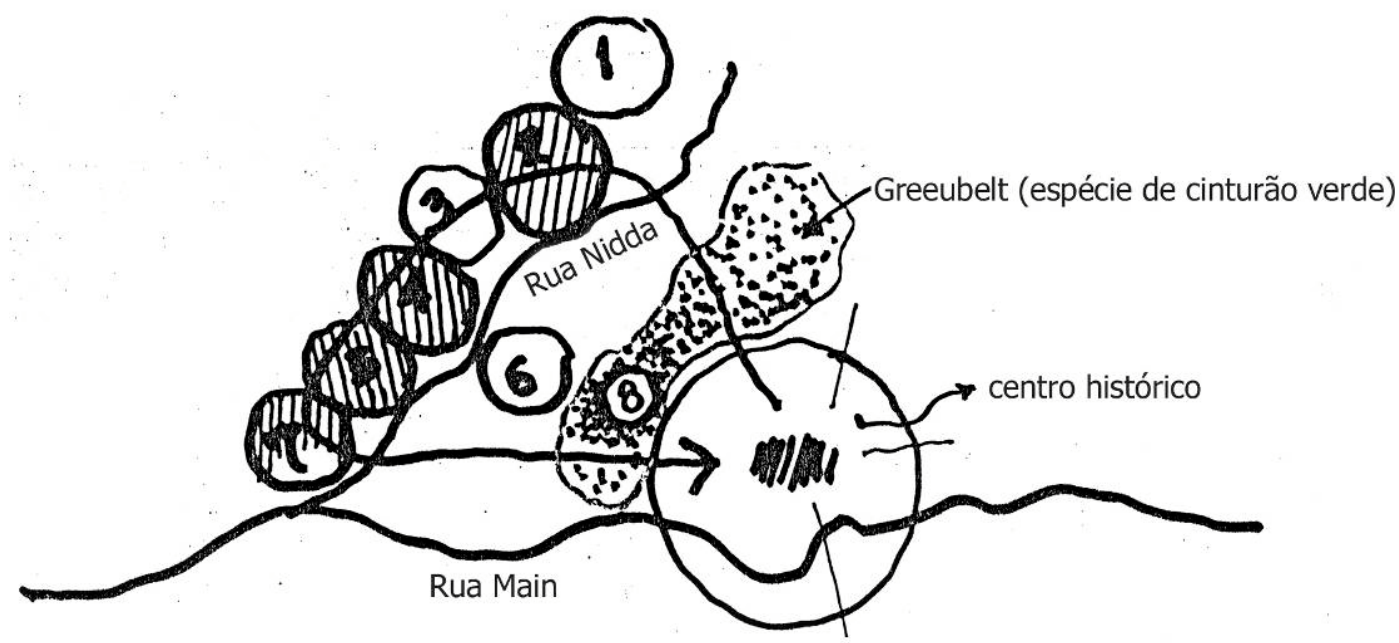

\section{Proposta urbana para Frankfurt}

1. Heddernheim (pequena cidade existente)

2. Romerstadt (Siedlung - conjunto habitacional)

3. Alt Praunheim (pequena cidade existente)

4. Praunheim (Siedlung - conjunto habitacional)

5. Westhausen (Siedlung - conjunto habitacional)

6. Hausen (pequena cidade existente)

7. Rodelheim (pequena cidade existente e Siedlung ou conjunto habitacional)

8. Jardim Botânico

BRUNA, Paulo, apontamentos de aula, disciplina AUH-5919-7, FAU-USP, 2004. 


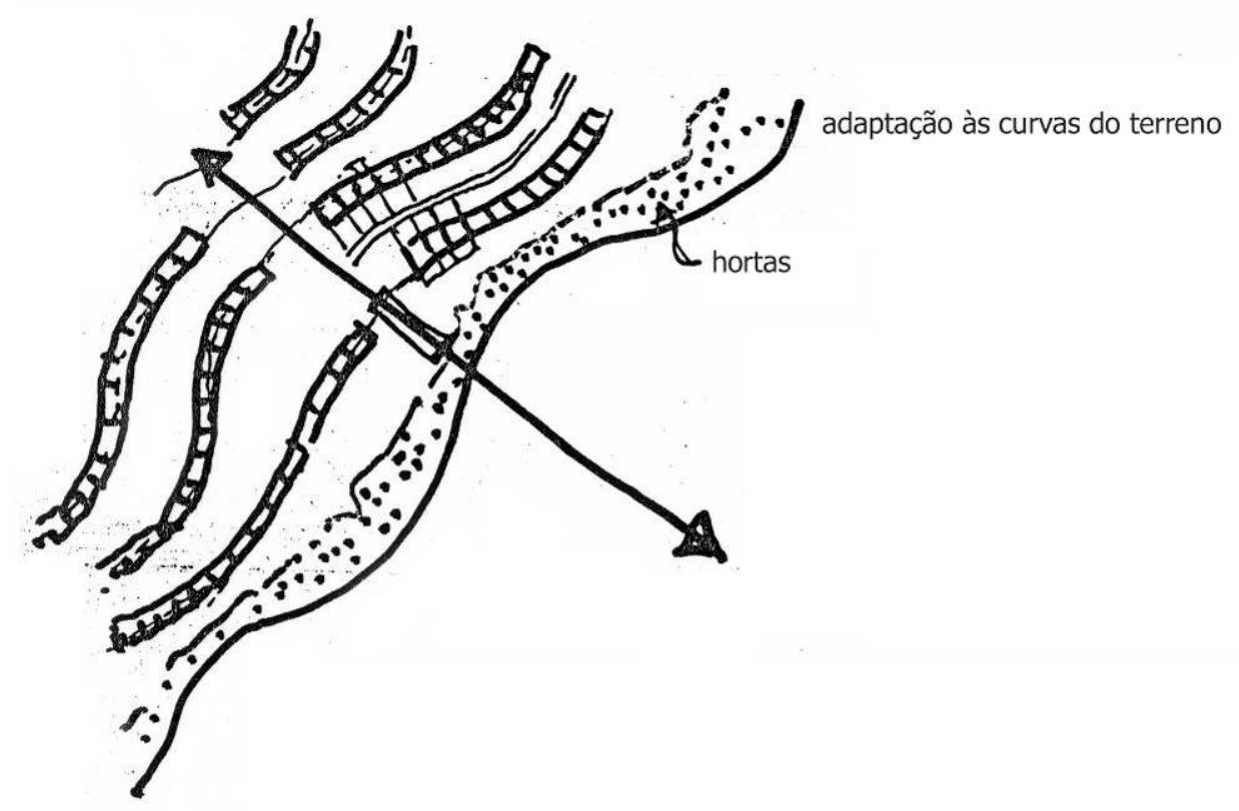

Planta esquemática dos primeiros conjuntos habitacionais da Equipe May.

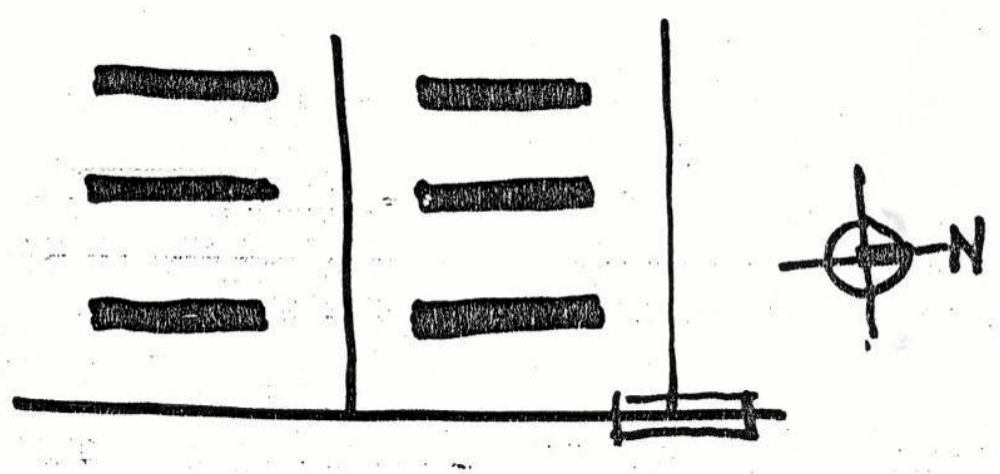

Planta esquemática dos últimos conjuntos habitacionais da Equipe May. BRUNA, Paulo, apontamentos de aula, disciplina AUH-5919-7, FAU-USP, 2004. 


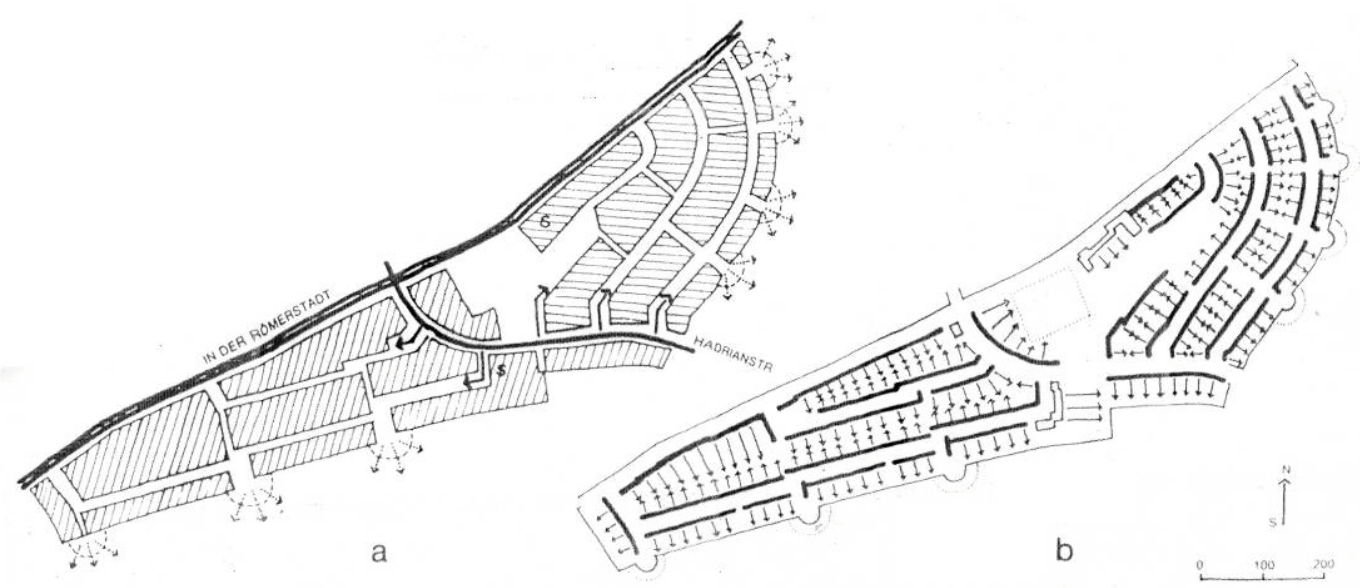

Ernest May. Siedlung Romerstadt

a) Divisão das unidades

b) 'Status' dos espaços

Os edifícios estão isolados uns dos outros, porém o conjunto funciona como um 'tecido' tradicional, marcando as diferenças e as oposições.
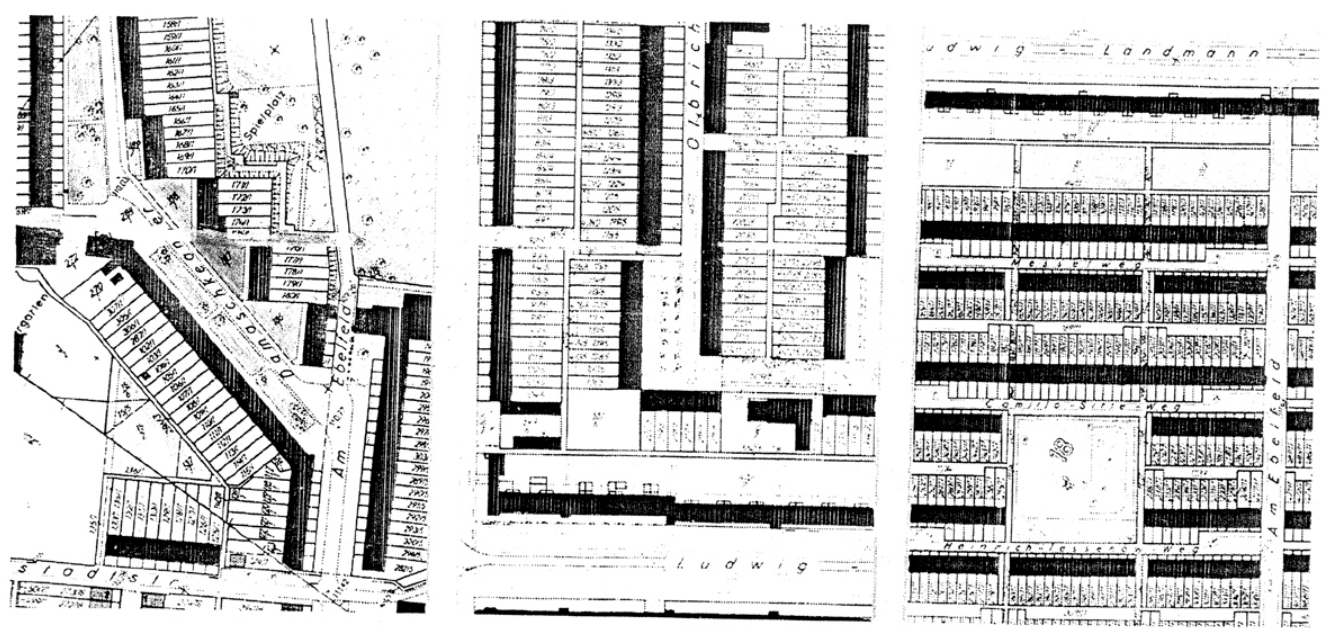

Ernest May. Siedlung Praunheim

As três etapas de execução, mesmo que pertencendo ao mesmo plano de conjunto, marcam a passagem progressiva do "pitoresco" ao "racional".

Castex, J.; Depaule, J. C.; Panerai, Ph., 1977. 

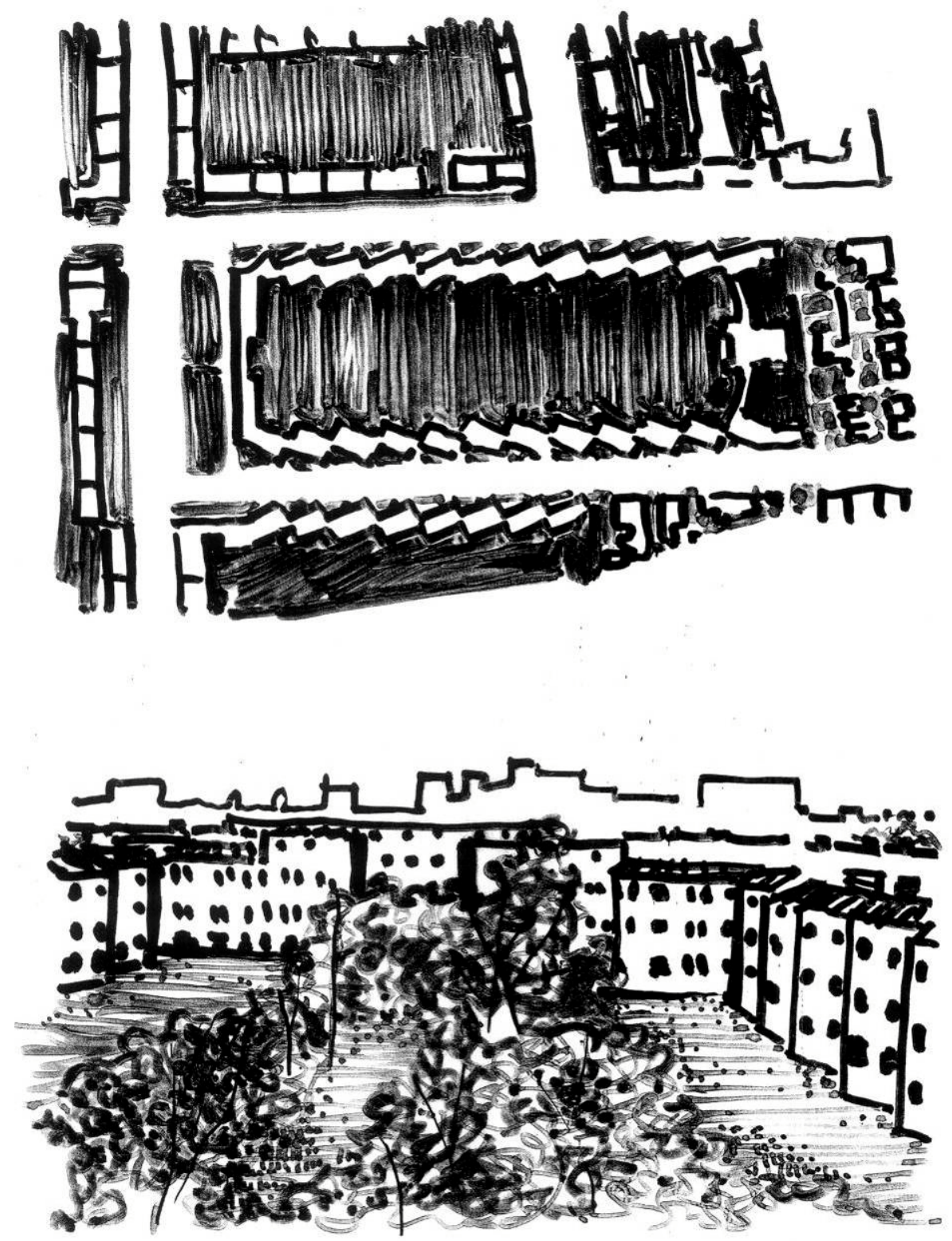

Ernest May, Siedlung Niederrad - Quadra "Zig-zag Hausen".

Planta e vista interior. Em uma região suburbana muito caótica, um jardim coletivo isolado do trânsito, na quadra fechada.

Desenho elaborado por Sylvia Dobry com base em fotografias publicadas por Castex, J.; Depaule, J. C.; Panerai, Ph., 1977. 


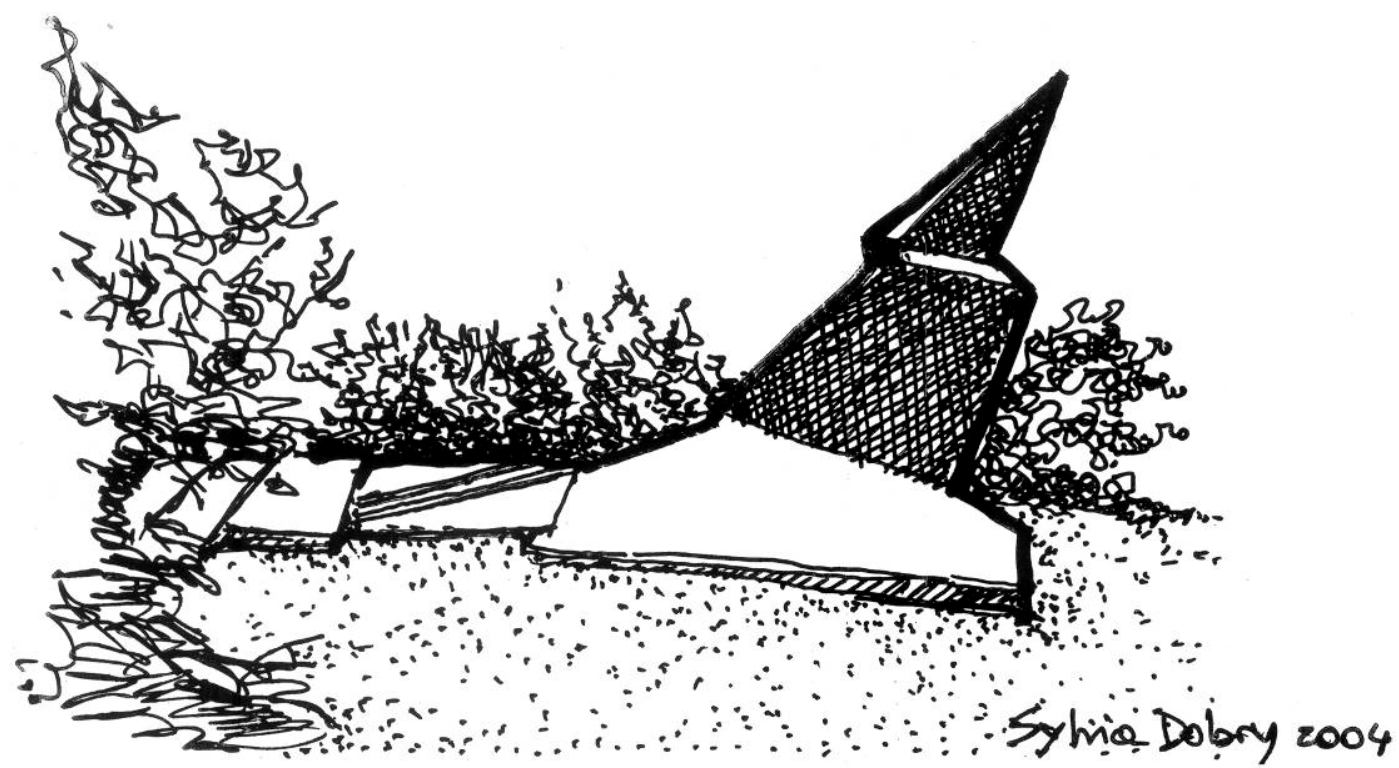

Monumento aos Mortos de Março, Weimar, 1921, homenagem aos assassinados pelos direitistas durante o "putsch" de Kapp em 1920, projetado por Walter Gropius.

Desenho realizado com base em fotografia publicada por Jencks, 1975: 42.

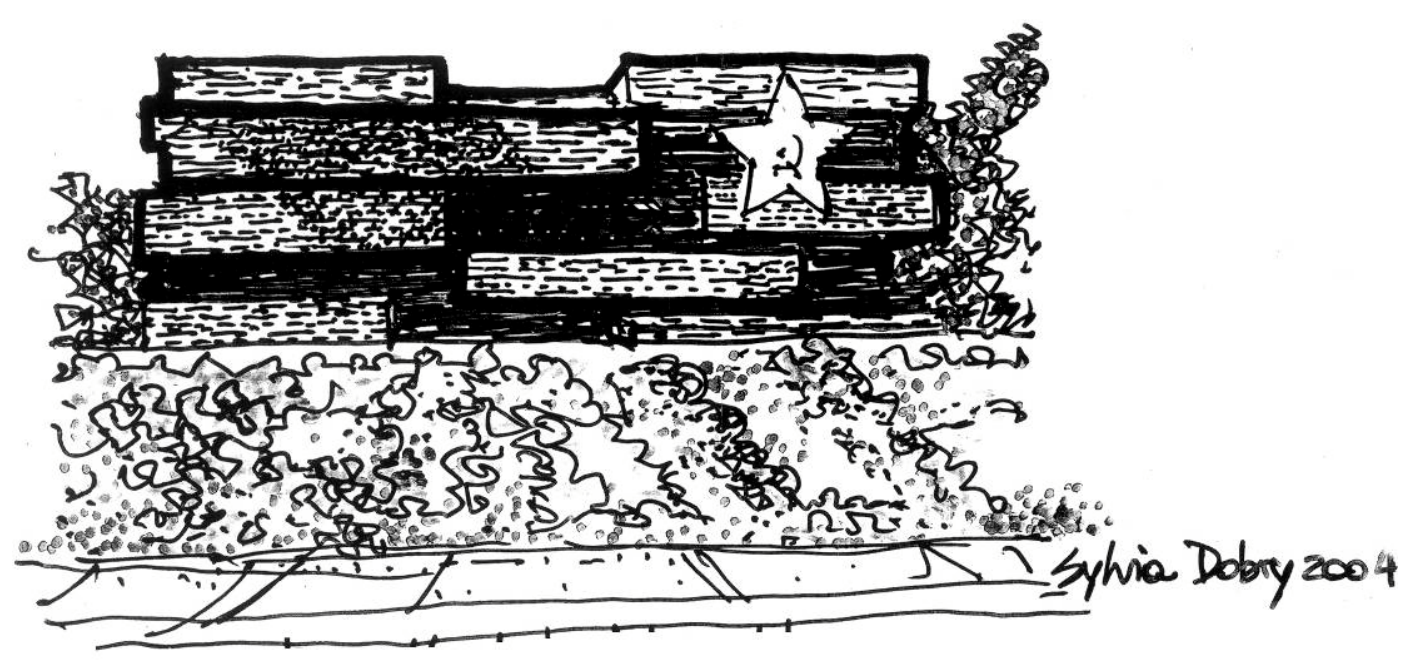

Monumento a Karl Liebknecht e Rosa Luxemburg, Berlim, 1926, projetado por Mies Van der Rohe.

Desenho realizado com base em fotografia publicada por Kopp, 1990: 69. 


\section{Capítulo II \\ O TALLER TOTAL}

\section{A inter-relação contexto - Taller Total}

O Taller Total da Faculdade de Arquitetura e Urbanismo da Universidade de Córdoba (Argentina) foi uma proposta de ensino que vigorou entre os anos 1970 e 1976, mas sua gestação remete aos anos 1960 e particularmente após o golpe militar de Juan Carlos Onganía, em 1966, como já foi dito em capítulos anteriores.

Nas origens e no desenvolvimento do Taller Total, o contexto políticosocial exerceu um constante e forte impacto, seja na gestação, seja na implementação, seja nas suas possibilidades de re-desenho, consolidação e no posterior fechamento ${ }^{1}$.

Na década de 1960, nos anos anteriores ao golpe militar de Onganía, muitos dos docentes da FAU-UNC interessavam-se pelo desenvolvimento de temas relacionados à vida dos usuários e suas necessidades. Porém esses professores, segundo Benjamim Elkin, sentiam que os fundamentos teóricos de que dispunham eram insuficientes para refletir sobre os temas propostos. As cadeiras de Composição Arquitetônica, do 10 ao 60 ano, vinculavam suas temáticas aos problemas sociais, mas a profundidade desenvolvida nelas não era homogênea. Professores de História da Arquitetura, como Elsa Larrauri e J orge Bonino, entre outros, faziam um esforço inovador a partir de suas disciplinas, relacionando o conhecimento do passado com a realidade vivenciada no período, incorporando, na sala de aula, discussões trazidas pelo cinema e pelas novas idéias de arte.

\footnotetext{
${ }^{1}$ A maioria das fontes consultadas coincide nessa afirmação. Ver Elkin, Benjamim, 2000; Martnez, Silvia A., 2000; Lamfri, Nora, 2007.
} 
De 1962 a 1966 grande parte da docência expressava a necessidade de um novo Plano de Estudos, o que se inseria na discussão latinoamericana e mundial sobre o ensino de arquitetura realizada nesses anos. Isso também era parte do ideário desenvolvimentista, que, desde fins da década de 1950, na Argentina, acreditava na educação como fator de mobilidade, capaz de promover desenvolvimento ${ }^{2}$. Em decorrência dessa idéia, houve importante aumento do número de matrículas nas universidades.

No plano político nacional, a década de 1960 esteve marcada pela proscrição do peronismo e pelo golpe militar de Onganía.

No aspecto econômico, verificava-se uma continuidade do desenvolvimentismo estabelecido por Arturo Frondizi em 1958. A ênfase dada, no discurso internacional, à relação entre educação, desenvolvimento econômico e estrutura ocupacional contribuiu para definir as políticas governamentais em que o planejamento tinha um valor estratégico ${ }^{3}$.

O golpe militar de junho de 1966 combinou um discurso modernizante no plano econômico e, no político, a aplicação das teorias da segurança nacional. As primeiras medidas adotadas incluem a suspensão das atividades dos partidos políticos e das instituições parlamentares. Criouse o Estado Maior da Presidência integrado pelos Conselhos de Segurança, de Desenvolvimento Econômico e de Ciência e Técnica. Nessa organização do poder estava implícita a idéia de que 0 planejamento econômico e a pesquisa científica constituíam componentes básicos da segurança nacional ${ }^{4}$. O cumprimento de grande parte do programa econômico de governo dependia da fragilização das organizações operárias, tanto por estas constituírem um obstáculo para os planos de racionalização da estrutura econômica do país e de atração de investimentos

\footnotetext{
${ }^{2}$ Martnez, Silvia A., 2000: 03.

${ }^{3}$ Lamfri, N., 2007: 55.

${ }^{4}$ Ibid: 56.
} 
estrangeiros, como também porque as organizações sindicais eram um fator de poder na sociedade argentina ${ }^{5}$.

A ênfase dada ao desenvolvimentismo priorizou o setor industrial e sua modernização e a passagem de empresas nacionais para estrangeiras. Congelaram-se os salários mediante conciliação obrigatória, modificaram-se as condições de trabalho em portos e ferrovias e iniciou-se o fechamento dos engenhos açucareiros no nordeste do país ${ }^{6}$.

Essas medidas provocaram protestos sindicais, que foram reprimidos com uma violência nunca vista até então. Com isso, o governo militar conseguiu enfraquecer toda dimensão de Estado de bem-estar que ainda se conservava na Argentina.

O golpe de Onganía havia interrompido violentamente a democracia na Argentina, proibindo as atividades políticas, perseguindo ideologicamente e produzindo demissões e suspensões nos órgãos públicos, entre eles, a Universidade. As faculdades tiveram seus quadros docentes desestruturados, em especial as de Córdoba, que se contam entre as que sofreram maior punição: Arquitetura, Filosofia e 0 Instituto de Matemática e Física ${ }^{7}$.

Por outro lado, o governo militar, dando continuidade ao desenvolvimentismo, priorizou o setor industrial. Promoveu-se também a modernização e a realização de grandes obras de infra-estrutura: conjuntos habitacionais, escolas, hospitais etc. Essa época, na Argentina, como ocorreu no Brasil, com suas particularidades, caracterizou-se pelas grandes construções. Era a fase do desenvolvimentismo, que coincidentemente toda a América Latina estava vivendo ${ }^{8}$. Realizou-se grande quantidade de concursos para

\footnotetext{
${ }^{5}$ Ibid. Esse tema foi desenvolvido em profundidade por J. Brennan,e M. Gordillo, no artigo "Protesta obrera, rebelión popular e insurrección urbana en la Argentina: el Cordobazo". Estúdios no 4, jul/dic. 1994; C.E.A.; U.N.C.Córdoba.

${ }^{6}$ Lamfri, Nora, 2007: 56.

${ }^{7}$ Elkin,B., 2000: 34.

${ }^{8}$ Martinez.Silvia A., 2000: 84.
} 
projeto e construção de conjuntos habitacionais, cujos clientes eram, em alguns casos, os sindicatos e, em outros, o Ministério de Bienestar Social, Secretaria do Estado de Vivienda (órgão federal), que passou depois a se denominar Secretaria de Estado de Vivienda y Urbanismo. Em todos os casos, o financiamento era do BHN (Banco Hipotecário Nacional), que tinha diversos planos de contratação, entre eles, Plan VEA, Plan Alborada e Plan 17 de Octubre.

A revista Summa registrou esses concursos, cujos projetos vencedores, de excelente qualidade arquitetônica e urbanística, são referência até hoje ${ }^{9}$. Isso revela que nesses anos o tema moradia de interesse social era considerado prioritário pela maioria dos arquitetos e assumido na sua prática profissional.

Para Silvia Martinez, "esse dado é importante, pois o social apresentase nesse momento como fator mobilizador da sociedade", passando da fase de democracia à de ditadura.

Em fins da década de 1960, universidades públicas, entre as quais Córdoba, Rosário, La Plata e Tucumán, destacavam-se como centros importantes de reflexão e crítica, concentrando grande número de estudantes. Nessas universidades, a busca de alternativas pedagógicas foi significativa, inserida num clima de agitação social e muitas expectativas políticas de mudanças estruturais. As novas metodologias provocavam também incertezas, dificuldades, conflitos e contradições. Porém implementaram-se diversos projetos com propósito de remover situações cristalizadas na tradição universitária argentina ${ }^{10}$.

\footnotetext{
${ }^{9}$ Suplementos Summa ; Recopilação dos nos. 36/49/71/72/76/78, desde 1971 até 1974. A n ${ }^{0} 11$, de 1968, era dedicada à arquitetura chilena, contendo diversos projetos para Povoados e Conjuntos Habitacionais. O concurso Summa para estudantes de arquitetura, de 1967/1968, cujo tema: "Moradia de interesse social”, considerado preparatório para o da União Nacional dos Arquitetos, foi registrado na revista Summa $n^{0} 13$. Nota-se que os prêmios dos concursos eram realizados mediante doações de empresas ligadas à construção, que tinham ainda um representante no júri. No nº 86 , de fevereiro de 1975, pode-se ler um artigo de Kenneth Frampton: "Evolución del concepto de vivienda, 1870-1970”. A revista Summa foi expressão importante do debate da arquitetura e urbanismo desses anos na Argentina, revelando suas temáticas, entre elas também políticas de novas cidades.

${ }^{10}$ Martinez, Silvia A., 2000: 01.
} 
Muitos dos docentes e estudantes eram impulsionados pela crença na possibilidade de mudar os rumos da história, o que contribuiu para que se empreendesse, em várias universidades públicas argentinas, uma fértil aventura pedagógica, resultando na criação de inovações teóricopráticas $^{11}$. Nestas, questionava-se a caducidade do modelo vigente e destacava-se a importância de inserir-se na realidade social e entendêla. Entre essas novas propostas pedagógicas, que abarcaram desde 0 ensino primário até o universitário, inclui-se o Taller Total, da FAUUniversidade Nacional de Córdoba.

Dois fatos marcantes constituíram pontos de referência para o Taller Total: o Maio Francês de 1968 e o Cordobazo, em 1969, nos quais se incluía resistência aos poderes estabelecidos e novas propostas culturais $^{12}$.

O Cordobazo - precedido por contínuos protestos sindicais e estudantis - foi uma insurreição popular na qual se materializou a unidade operária-estudantil e à qual se somaram outros setores sociais, expressando o descontento e a crise social latente que estava se incubando nesses anos. O Cordobazo revitalizou a esquerda argentina e contribuiu para a radicalização da vida política do país [...] 0 mundo subterrâneo da política revolucionária, perseguido e clandestino desde os primeiros dias do onganiato, saiu das sombras para ocupar um lugar central na vida nacional ${ }^{13}$.

Pode-se dizer que a partir dessa insurreição popular em Córdoba os modelos de dominação social entraram em crise, aumentando dia a dia o questionamento às autoridades e ao poder. 0 mito da ordem e da autoridade do regime foi caindo, aprofundando a crise. Em junho de 1970 foi designado pela junta de Comandantes o general Roberto Levington, que governou por apenas nove meses, sendo substituído pelo general Alejandro Lanusse em março de 1971.

\footnotetext{
11 Ibid.

12 Todas as fontes consultadas coincidem nesta afirmação.

13 Brennan, J. 1996: 218.
} 
Nesses anos a Universidade sofreu intervenção, houve suspensão das atividades acadêmicas por longos espaços de tempo, demandas estudantis violentamente reprimidas e, na FAU-UNC, momentos de acefalia.

A gênese de uma transformação da magnitude proposta pelo Taller Totalfoi possível pela existência de um ambiente político-intelectual efervescente, de produção intelectual e participação universitária nos anos 1960, que os acontecimentos políticos de 1966 vividos na Universidade Nacional de Córdoba e a ditadura de Onganía não conseguiram silenciar.

A experiência do Taller Total consistiu na incorporação de todos os estudantes e professores da faculdade na construção de uma proposta interdisciplinar e com um currículo inovador. Foi desenvolvida a partir de três premissas fundamentais:

- A arquitetura é uma profissão de caráter prioritariamente social.

- Seu ensino deve partir da análise da sociedade e suas necessidades.

- Sua gestão deve ser democrática e participativa ${ }^{14}$.

Mas até se chegar a essa formulação, trilharam-se caminhos complexos, que tentarei sintetizar a seguir.

A intervenção na FAU-UNC em 1966 provocou um impasse nos debates que se vinham processando sobre o ensino de arquitetura. E, a partir de 1967, a situação tornou-se confusa em relação à definição da estrutura acadêmica. As práticas realizadas contribuíam para acentuar a fragmentação nas cátedras, sem estabelecer conexões sólidas. Houve alguns ensaios de direção central, tais como Corpo Assessor, Equipe Diretora etc ${ }^{15}$. Alguns dos professores suspensos em 1966 já se tinham reintegrado às suas funções, entre eles, Juan Carlos Fontán.

Em 1969, o Conselho Acadêmico apresentou uma portaria na qual se dispunha a divisão do ano letivo em dois quadrimestres: no primeiro

\footnotetext{
${ }^{14}$ A maioria das fontes consultadas coincide nessas afirmações. Ver: Martinez, S., 2000: 6668; Elkin, 2000; Lamfri, 2007.
} 
se desenvolveriam só as disciplinas teóricas e no segundo as de ateliê $^{16}$. Assim, Composição Arquitetônica e Urbanismo separavam-se das outras disciplinas. Essa dicotomia, que fazia reviver a antiga dissociação e que, por isso, provocou resistências ${ }^{17}$, não chegou a ser aplicada por considerar-se que "cristalizava um critério verticalista e rígido do ensino, assim como uma forte limitação nos campos de conhecimento e conseqüentemente na sua ação"18.

A proposta do Conselho Acadêmico continha uma aparente flexibilização da estrutura acadêmica tradicional, cujas unidades organizativas básicas eram as cátedras. Ensaiava combinações que deram origem a outras formas, como por exemplo, os ateliês verticais autônomos, porém hierárquicos. De fato, ao manter o mesmo conteúdo e direcionamento, essa proposta constituía-se em uma variação formal da mesma coisa ${ }^{19}$.

O Conselho Acadêmico solicitou aos docentes a elaboração de propostas visando resolver a crise, cada vez mais complexa. Em resposta a essa solicitação, formaram-se dois grupos, o que, segundo 0 arquiteto Nizzo, se devia às diferentes orientações ideológicas dos professores $^{20}$.

\section{Duas propostas de ensino}

A maioria das fontes consultadas coincide em caracterizar como ato fundador do Taller Total a reunião na qual foram apresentadas as duas propostas curriculares. Essa reunião realizou-se em agosto de 1970 (já no período da presidência do general Levington) na sala do Conselho

\footnotetext{
${ }^{15}$ Fontàn; Novillo Corvalán, 1971: 02.

${ }^{16}$ Ibid.,:03. Trata-se da portaria no. 1/70, durante a gestão do arquiteto Rogério Luque, apud Lanfri, 2007: 78.

${ }^{17}$ Fontán; Novillo Corvalán, 1971: 03.

${ }^{18}$ Documento de Trabajo, Propuesta de Plan de Estúdio. Dirección de Servicios Culturales y Publicaciones de la FAU-UNC. Córdoba, julho de 1971: 01 apud Lamfri, 2007: 78.

${ }^{19}$ Documento de docentes e alunos: "Fundamentación de contenido y forma del Taller Total". Córdoba, FAU-UNC, 1970:01 apud Lamfri, 2007: 79.

${ }^{20}$ Nizzo, Edgardo, entrevista concedida a Elkin, 2000: 179-186.
} 
Acadêmico. Em um dos grupos trabalharam os arquitetos Carlos Alberto Villada, Osvaldo Ramacciotti, Pedro Fiorito e Edgardo Nizzo, que, com base nas idéias debatidas, elaborou a proposta do grupo. Consistia em um Ateliê Vertical dos níveis III, IV e V de Composição Arquitetônica. Os níveis I, II e o Trabalho Final não participariam. Autocriticamente, Nizzo diz que sua proposta era só funcional, não se estruturava sobre um eixo que contivesse as atividades vivenciadas na FAU-UNC e deixava de lado as relações cidade/moradores, arquitetura/lugar e a construção de uma linguagem nacional de arquitetura ${ }^{21}$. No entanto, esses elementos estavam presentes sem serem explicitados.

Nizzo afirma, em seu depoimento, que tinha dúvidas a respeito de urbanismo fazer parte do Ateliê Vertical, pois na época não estava claro se os conhecimentos que tinham sobre a construção da cidade eram suficientes para constituir um conteúdo de Composição Arquitetônica: "Sabíamos do urbanismo funcionalista a que Devoto [aderia] e suas idéias quanto às ações do Maio Francês de 1968, e as idéias questionadoras de outros, como Lefevbre"22. Ele acrescenta que, no entanto, não eram conceitos suficientemente elaborados para serem incorporados às aulas. 0 arquiteto Miguel Angel Cuenca, também docente da FAU-UNC, sintetizou sua posição com a frase: "As cidades não são belas por suas fontes, senão por seus moradores". Essa visão, segundo Nizzo, era comum a todo o grupo, embora não a toda a FAUUNC; e também não estava claro para a docência de que maneira essa idéia poderia ser elaborada no ensino de arquitetura.

"Na reunião em que li minha proposta", disse o arquiteto, ao escutar a outra, percebi que ela considerava muitos aspectos que eram parte de minhas inquietações e interesses. Até então não sabíamos quem eram todos os que propunham o Taller Total e que contavam com o apoio dos pedagogos. Ao ouvir a proposta lida por Fontán, vi que ela superava a que eu havia redigido e enfocava o problema em questão:

\footnotetext{
${ }^{21}$ Nizzo, Edgardo, entrevista concedida a Elkin, 2000: 179-186.

22 Ibid.
} 
apresentava um Ateliê Vertical ${ }^{23}$ completado com a proposta de conteúdos, que se desenvolvia em construção coletiva do conhecimento.

Nizzo esclarece que sempre foi ortodoxo sobre a relação docente/estudante (o docente sempre deve saber, desde o início, mais do que quem aprende, propor questionamentos e trabalhar de forma interdisciplinar). A proposta apresentada por Fontán valorizava a interdisciplinaridade, tanto entre matérias específicas da área - as tecnológicas -, como entre as mais gerais: Antropologia, Economia e Sociologia, o que foi difícil implementar corretamente $[\ldots]^{24}$. Ainda segundo Nizzo, surgia na proposta de Taller Total apresentada por Fontán "a possibilidade de recorrer a conteúdos de qualquer outra disciplina e nível para complementar a formação do estudante [...]" e estava implícita a possibilidade de que docentes diferentes colaborassem nessa formação. Por exemplo: No Nível II o estudante organiza e estrutura uma situação urbano/social de objetos arquitetônicos como a rua, a pracinha, o setor, tudo aquilo que para um ser humano é parte do seu cotidiano, que lhe pertence ao sair e voltar para sua casa.

A interdisciplinaridade permitia que qualquer docente de qualquer nível pudesse falar sobre uma infinidade de aspectos, que em uma estrutura tradicional estaria em outro nível ou em outro ano. Incorporando toda a FAU-UNC, ela superava amplamente as lacunas de conhecimento. "Por essas razões Villada e eu votamos a proposta que Fontán e seu grupo fizeram", afirmou Nizzo, continuando: No Manifesto do Taller Total havia conteúdos marxistas. Não me incomodaram, pois não temo pensamentos diferentes dos meus, e os aceitei porque entendi que estávamos vivendo um momento de elucidação de idéias. Assinar o Manifesto não significava aderir a esses conteúdos. Propus adicionar

\footnotetext{
${ }^{23}$ No início tratava-se de um Ateliê Vertical, com o nome de Taller Total de Composição Arquitetônica.

${ }^{24}$ Nizzo, Edgardo, entrevista concedida a Elkin, 2000: 179-186.
} 
uma cláusula que convidava pessoas de outras correntes [políticas] a participar da experiência ${ }^{25}$, o que foi aceito. Porém algumas pessoas se inibiram de assinar esse Manifesto. Ainda segundo Nizzo, Villada assinou, esclarecendo que não compartilhava os conteúdos de origem marxista.

O depoimento desse arquiteto revela a coexistência de diversas correntes políticas na experiência do Taller Tota/na FAU-UNC. Muitas vezes em meio a acirrados debates, manteve-se a possibilidade do diálogo, o que, embora com variações de ritmo, tornou possível que a experiência didática não se interrompesse.

No outro grupo participaram, entre outros, os arquitetos Ricardo Veteri, Fernando Gomez, Mauro Pistorio, Juan Carlos Fontán e alguns estudantes, como Carlos Rujinski, Eduardo Fernandez e Montenegro ${ }^{26}$. Para elaborar sua proposta, esse grupo solicitou, desde o início, o apoio de profissionais de Ciências da Educação que se haviam destacado anteriormente numa experiência frutífera, datada de 1966, durante a gestão do arquiteto Taranto na diretoria: Lucia Garay e Alicia Carranza. Em meados de 1970 elas foram convidadas a participar da elaboração da proposta do Taller Total (inicialmente Taller Total de Composição Arquitetônica), somando sua atuação às de Marta Casarini e Maria Saleme de Burnichón, pedagoga de reconhecida experiência.

As duas propostas foram lidas na sala do Conselho Acadêmico, durante a reunião. Quase por unanimidade, foi aprovada a apresentada pelo arquiteto Fontán, dando-se assim início ao Taller Total.

A maioria das fontes consultadas coincide em afirmar que a iniciativa sobre o Taller Total surgiu de um grupo de jovens docentes (em sua maioria Chefes de Trabalhos Práticos) da FAU-UNC e alguns alunos com que compartilhavam pontos de vista a respeito da formação do arquiteto.

\footnotetext{
25 Ibid.

${ }^{26}$ Nizzo, Edgardo, entrevista concedida a Elkin, 2000: 179-186.
} 
Nas entrevistas abaixo, alguns participantes relembram os acontecimentos:

- Nos anos 1970 houve um encontro com um grupo de estudantes e docentes jovens que me propuseram trabalhar juntos para a reformulação da carreira, e então surgiu o que se chama Taller Total ${ }^{27}$

- [...] o Taller Tota/ não se originou somente de docentes, havia um grupo de alunos que estava finalizando o curso, foram eles que mobilizaram os professores e juntos iniciaram o Taller Total ${ }^{28}$ - [...] foi uma exigência em grande medida da maior parte dos estudantes acompanhados de docentes mais jovens e comprometidos. Uma exigência de "tomar a faculdade". Por isso chamou-se Taller Total [...] tínhamos desde 0 ateliê de primeiro ano até 0 ateliê do trabalho final ${ }^{29}$.

Para a equipe de Pedagogia da FAU-UNC, a participação estudantil foi significativa na etapa inicial do processo, esclarecendo que não era o movimento estudantil enquanto tal o autor do projeto do Taller Total. A paternidade do documento básico que o define e fundamenta deve-se à confluência das preocupações de um grupo de docentes da FAU e um grupo de estudantes que não estão desvinculados do movimento estudantil, mas que não constituem representação orgânica dele ${ }^{30}$. Após a reunião considerada fundante, acirra-se a crise na faculdade, que culmina com a renúncia do diretor e do Conselho Acadêmico. A partir de setembro de 1970 foi designado o arquiteto J uan Carlos Fontán como diretor-interventor da FAU-UNC e iniciou-se um período em que foram tomadas resoluções que permitiram encaminhar a transformação do Plano de Estudos, que o Taller Totaldemandava ${ }^{31}$.

\footnotetext{
27 Depoimento de participante da equipe de Pedagogia apud Lamfri, 2007: 80.

${ }^{28}$ Depoimento de docente de arquitetura apud, Ibid.

${ }^{29}$ Depoimento de participante da equipe de Pedagogia, apud Lamfri, 200: 80.

${ }^{30}$ Equipe de Pedagogia FAU-UNC, 1971, p. 07 ,apud Lamfri, 2007:80.

${ }^{31}$ A maioria das fontes consultadas coincide nesses dados. Optei por traduzir o termo Decano como Diretor por ser mais compreensível no Brasil.
} 
Cabe aqui lembrar que, em decorrência da intervenção nas

Universidades pela ditadura militar de Onganía e a perda da autonomia universitária, os diretores, que eram eleitos, passaram a ser nomeados pelas autoridades governamentais.

\section{O contexto universitário}

Considero necessário, visando a melhor compreensão do processo do Taller Total da FAU-UNC, comentar brevemente a situação da Universidade argentina nesses anos.

A década de 1960 caracterizou-se na Argentina por mudanças significativas no nível universitário, seja academicamente, seja politicamente. O golpe de 1966, após anos de "democracia restringida", “interrompeu o desenvolvimento e a consolidação das instituições universitárias, instalando um clima de autoritarismo e opressão, pretendendo suprimir toda atividade política no seu interior" ${ }^{\prime 32}$. O marco dessa política foi a chamada Noite dos Bastões Longos, cujo palco foi a Faculdade de Ciências Exatas da Universidade de Buenos Aires e que deu início a um período repressivo nas universidades do país. Interrompeu-se uma fecunda polêmica cultural, da que participavam docentes, estudantes e graduados, que integrava objetivos e intenções superando diferenças políticas ${ }^{33}$.

A ditadura desenvolveu uma perseguição anticomunista, e a toda manifestação de oposição política ou acadêmica, impondo um autoritarismo acadêmico e proibindo temas modernizadores e críticos. Textos de Marx, Freud e Darwin foram banidos das universidades argentinas, que deveriam se adequar às exigências da Segurança Nacional.

\footnotetext{
${ }^{32}$ Lamfri, 2007: 61.

${ }^{33}$ Ibid. Esse tema foi desenvolvido por A. Gaite no artigo Reflexões acerca de la enseñanza de la Arquitectura, Revista Summa Universitária, no. 1, Buenos Aires, 1986.
} 
Por outro lado, verificou-se uma política de modernização do Sistema Universitário Nacional na que se incluíam:

- diversificação da oferta de cursos;

- criação de títulos intermediários;

- aumento do número de professores com dedicação exclusiva;

- organização departamental ${ }^{34}$.

Com o objetivo não declarado de evitar a concentração de jovens estudantes nas grandes universidades existentes, criaram-se outras 16 universidades no território argentino, com base no Projeto de Planejamento Universitário ${ }^{35}$.

A partir de perspectivas diferentes, essa política universitária foi objeto de críticas - entre outras, a de que o sistema de departamentalização tinha origem em modelos norte-americanos e respondia a uma realidade social, econômica e política diferente da argentina ${ }^{36}$. Outras críticas eram referentes à destinação de verbas às novas universidades, um problema diante do déficit crônico das já existentes. Durante o governo de Arturo Illia, 1965 e 1966, foram anos de intensas mobilizações estudantis por mais orçamento para as universidades.

Em reação à lei que suprimia a autonomia universitária durante a ditadura de Onganía, o reitor da UNC e os diretores das faculdades renunciaram, entre eles o da FAU-UNC, arquiteto Bernardino Taranto. As renúncias, demissões e suspensões significaram o enfraquecimento de cátedras e equipes de pesquisa com conseqüências profundas para a Universidade Argentina ${ }^{37}$.

\footnotetext{
${ }^{34}$ Lamfri, 2007: 62. A reorganização do Sistema Universitário foi realizada com base na Lei Orgânica das Universidades Nacionais no. 17245/67; na Lei de Ensino Universitário Privado no. 17640/67 e seu decreto no. 8472/69 e a Lei das Universidades Provinciais no. 17718/68, segundo Nora Lamfri.

${ }^{35}$ Lamfri, 2007: 62.

${ }^{36}$ A respeito pode-se consultar: Martinez Paz. El sistema educativo nacional. Formación, Desarollo - Crisis. Córdoba, UNC,1986.

${ }^{37}$ Esse tema foi amplamente desenvolvido por Luiz Rebora: FAU. Cronologia Testimonial. Córdoba, FAU-UNC, 1991.
} 
A FAU-UNC tinha levado 10 anos para formar e consolidar o quadro de professores. Na crise iniciada com o golpe militar de 1966, a maioria dos professores que renunciaram, foram demitidos ou suspensos pertenciam às cátedras de Composição Arquitetônica. A coluna vertebral da FAU-UNC tinha sido quebrada, o que era particularmente doloroso e frustrante para os estudantes, para os jovens professores que permaneceram e para os que voltaram depois de terminado 0 prazo das suspensões.

Em 1968, cinqüentenário da Reforma Universitária, uma conjunção de fatores, entre eles a oposição estudantil à condução política do país e das universidades, o descontentamento de grandes setores da classe média, a possibilidade da aliança operário-estudantil, a radicalização de diversos setores, como, por exemplo, o movimento da Igreja de Terceiro Mundo, somados aos acontecimentos do Maio Francês, contribuíram para que se fortalecesse a agitação estudantil.

Os estudantes iniciaram protestos nas Universidades do Nordeste e do Rosário, que se estenderam a outras universidades, entre alas a UNC cujos alunos, como foi relatado anteriormente, viriam a ser protagonistas no Cordobazo, em 1969.

Durante esses anos, tanto os reitores das universidades quanto os diretores das faculdades cumpriram, na maioria das vezes, funções burocráticas, deixando à margem as questões e os conflitos acadêmicos. I sso gerou um crescente descontentamento entre os alunos e muitos dos professores, o que ocorreu na FAU-UNC. Frente à renúncia de seu diretor, arquiteto Rogelio Luque, e dos membros do Conselho Acadêmico, o reitor designou o arquiteto Juan Carlos Fontán como diretor-interventor - cargo em que estavam reunidas as “atribuições que a lei e o Estatuto da UNC davam ao diretor da Faculdade e ao Conselho Acadêmico" ${ }^{38}$ - , em cuja gestão iniciou-se a

\footnotetext{
${ }^{38}$ Lamfri, 2007: 66. Em novembro de 1970 renunciaram a seus cargos o Professor Adjunto (que não o exercia havia vários meses), os ex-diretores-interventores arquitetos Urretz Zavalia e Rogelio Luque, por não concordarem com a orientação tomada pela FAU-UNC. No plano
} 
experiência do Taller Total na FAU-UNC a partir de $1^{10}$ de setembro de 1970.

Considero interessante conhecer a opinião de Fontán sobre esse período inicial do Taller Total. "A FAU está sem cabeça [...]. Se realiza uma reunião com o Subsecretariado de Interior da Nação, arquiteto H. Taboada. Nela se fala sobre a acefalia da FAU [UNC], que desejávamos manter aberta, e argumentamos que o documento [do Taller Tota/] era uma via [para cumprir esse objetivo]. Taboada me propõe para Diretor, mas nego essa possibilidade pelo fato de ser um dos suspensos em 1966 e por desconhecer [as questões administrativas]. Taboada responde que averiguará meus antecedentes e aparecem dados de exaluno do Liceo Militar, ex-lasallista, família sem mudanças: "normal". [Frente a esses dados], Taboada diz "é você" Depois dessa reunião chamo o Gomes [...] perguntando [sua opinião]"39.

A resposta do arquiteto Fernando Gomes foi afirmativa. Ele era um dos professores com maior visão crítica, articulando dialeticamente os conhecimentos disciplinares de arquitetura com os políticos.

A condição que Fontán impôs ao aceitar o cargo de diretor foi que se pusesse oficialmente em marcha o Taller Total.

O início, segundo Fontán, "foi em um clima difícil, em uma assembléia enorme: me fizeram críticas acirradas, mas me deixaram trabalhar"40. A equipe de apoio à diretoria estava formada por Novillo Corvalán na administração, Robledo na legislação, Veteri no acadêmico e Gomes como principal articulação com os estudantes. Ainda na opinião do então diretor-interventor, Pistorio trabalhou com dedicação na Tecnologia, Garimano despendeu grande esforço do ponto de vista ideológico, Eric King destacou-se na Coordenadoria, fortalecendo a relação entre os docentes, o Taller Total e o diretor. Pellegrino, provocava profundos embates com muitos dos jovens professores que aderiam às posturas do Team X, discussões que chegavam à FAU-UNC com certo atraso.

${ }^{39}$ Fontán, Juan Carlos. Depoimento a Elkin, 2000: 171-176. 
experiente funcionário da área Administrativa Contábil, foi insubstituível no esforço de atribuição dos cargos, a maioria por meio de contratações. Essas, segundo Fontán, foram o símbolo do caos geral que se vivia na FAU-UNC, já que quase todos os docentes eram temporários e somente $5 \%$ eram contratados por concurso público, entre eles cinco ou seis professores titulares.

\section{O período inicial}

Após a designação do diretor-interventor, em setembro de 1970, iniciou-se um período de definições que possibilitou o encaminhamento da transformação curricular.

Por questões internas e externas, o ano letivo de 1970 prolongou-se até agosto de 1971, quando se realizaram as avaliações ${ }^{41}$.

Diversas medidas foram adotadas, como, por exemplo, a criação do Taller de Elementos de Arquitetura (TEA), que depois passou a chamarse Taller Básico, visando a concentração, no ateliê, dos aportes básicos necessários para o aprendizado de arquitetura e urbanismo, que se manteve separado do Taller Total. Algumas disciplinas teóricas continuaram sendo ministradas com o objetivo de nivelar o conhecimento dos alunos.

Paralelamente, o Taller Básico foi ministrado até o fim do ano para os estudantes que ingressaram em 1971. Esse, até o ajuste dos objetivos, conteúdos e mecanismos do Plano de Estudos, funcionou como uma unidade pedagógica independente do Taller Total, ainda assim seguindo suas linhas gerais ${ }^{42}$.

\footnotetext{
40 Ibid.

${ }^{41}$ Resolução no. 181/70 de 30/10/70: Fontán determina nove horas didáticas por dia, no Taller Total, para recuperar os dias letivos perdidos por decorrência do contexto político geral. Em Córdoba houve muitas mobilizações de protesto estudantil, reprimidas com violência cada vez maior, por exemplo: a ocupação do Hospital Nacional das Clínicas, ocupação da Reitoria e de faculdades. O Conselho Superior da UNC suspendeu as atividades em várias faculdades e Institutos Superiores. Esse tema foi tratado com mais detalhamento por Lamfri, 2007: 95.

${ }^{42}$ Fontán, J. C.; Novillo Corvalán, M., 1971:03-04.
} 
Em 1970, estavam matriculados um total de 1986 alunos e o corpo docente era formado por 50 professores. Esses números aumentaram para aproximadamente 4.000 alunos e mais de 300 professores durante o processo do Taller Total. Por volta de 1.525 alunos, pertencentes aos níveis II ao IV, organizaram-se em 12 equipes de trabalho: de 126 a 129 estudantes de diferentes níveis em cada um ${ }^{43}$. Ao Taller de Elementos de Arquitetura compareciam aproximadamente 400 alunos, aos quais se somaram, em 1971, os que ingressaram no Taller Básico.

Em dezembro de 1971 foi realizada a primeira publicação ordenadora dos aspectos do Taller Total, conhecida como Livro Mostarda e assinada por J uan Carlos Fontán, diretor-interventor, e Marcelo Novillo Corvalán, secretário. Essa publicação tinha como base, segundo seus autores, o documento elaborado no ano anterior por um grupo de docentes e alunos, com 0 assessoramento de uma equipe de especialistas em Ciências da Educação, contendo uma proposta de ação imediata, apresentada na reunião considerada fundadora, citada anteriormente. Considero fundamental analisar alguns aspectos dessa publicação.

\section{O Taller Total - considerações gerais}

“A Universidade Argentina é depositária natural das aspirações sociais, enquanto projeto do futuro [... e] deve canalizar os requerimentos atuais e os por vir, a partir do que deverá plasmar sua ação. [... para isto deve contar] com objetivos ajustados à realidade, seja nas atividades de formação, seja nas atividades do futuro profissional, que serão inseridas" ${ }^{\prime 4}$.

\footnotetext{
${ }^{43}$ Segundo a Síntese Estatística Universitária 1968-1975, realizada pela Direção de Planejamento - Departamento de Estatística - UNC (1976), os estudantes da FAU-UNC eram em 1968: 1.295, dos quais 191 eram novos inscritos; em 1969: 1.480, dos quais 340 novos inscritos; em 1970: 1.986, dos quais 690 novos inscritos; em 1971: 2.194, dos quais 651 novos inscritos; em 1972: 2.250, dos quais 686 novos inscritos; em 1973: 2.807, dois quais 745 novos inscritos; em 1974: 3.912, dos quais 1.215 novos inscritos; em 1975: 3.414, dos quais 869 novos inscritos. O número de professores era em 1970: 50; em 1973: 305; em 1974: 349; em 1975: 318.

${ }^{44}$ Fontán, J. C.; Novillo Corvalán, M., 1971: 03-04, grifo nosso.
} 
Questionava-se, no Livro Mostarda, que a Universidade, na maioria das vezes, desvinculava-se da realidade, desajustando seus conteúdos, objetivos e métodos. No caso das FAUs, criticava-se uma formação do arquiteto adequada a um modelo europeu ou norte americano, porém não capacitado para responder aos aspectos complexos da realidade social. 0 arquiteto de formação enciclopédica-esteticista não consegue responder às urgências de um país subdesenvolvido, regionalmente desequilibrado, de industrialização incipiente e de economia básica agropecuária. E não se vê positivamente um profissional técnicoeficientista que transplanta concepções e técnicas difundidas em sociedades com outra situação econômica, técnica e científica ${ }^{45}$.

\section{Fundamentação geral}

Ainda no Livro Mostarda, afirma-se que "a firme conviç̧ão da necessidade da redefinição crítica do papel do arquiteto, a concepção e a arquitetura que o determina e seu ensino "aqui e agora", tem impulsionado docentes e alunos da Faculdade de Arquitetura e Urbanismo da Universidade Nacional de Córdoba a assumir-se como atores de um processo que possa levar a compreender a arquitetura como prática social, gerada na sociedade, interpretada interdisciplinarmente, assumida e resolvida pelo arquiteto e na qual o usuário é seu destinatário, continuador e realizador em comunidade do produto: o habitat humano.

Para determinar os objetivos do processo devemos responder à pergunta: que arquiteto queremos formar? [...] "querer formar" implica vontade de ação, mas, para que ela alcance uma dimensão categórica, devemos [pensá-la] em função das necessidades de nossa sociedade. Isso implica o conhecimento profundo dessas necessidades no momento atual $[\ldots]^{n 46}$.

\footnotetext{
${ }^{45}$ Ibid.: 06.

${ }^{46}$ Fontan, J. C.; Novillo Corvalán, M., 1971; 07-08, grifo nosso.
} 


\section{A relação ensino-contexto}

Ainda no Livro Mostarda se faz uma crítica à estrutura de ensino ministrada até esse momento na FAU-UNC: “[...] tradicional forma acadêmica-messiânica, como relação entre o professor, [...] ativo, e o aluno, $[. .$.$] passivo e receptor, que [...] leva o ensino à condição de$ simples 'cerimônia' "47.

Verificava-se também uma incapacidade dessa estrutura de receber e absorver o impacto provocado pelo ingresso das massas na universidade $^{48}$. Para entender o significado desse fato, cabe aqui fazer algumas considerações sobre os estudantes universitários da época na cidade de Córdoba. Muitos eram oriundos de outras localidades, seja do interior da província, seja das regiões norte, leste e sul do país, como também de outros países, como Peru, Bolívia, Brasil. A maioria morava em pensões, repúblicas e grandes colégios, que caracterizavam determinados bairros da cidade como estudantis.

Cabe destacar também que na década de 1960 surgiu o estudante trabalhador, pois nesses anos se produziu uma entrada significativa de alunos na universidade pública, provenientes das classes médias e de menor poder aquisitivo ${ }^{49}$.

Essa alteração quantitativa se relacionava a uma mudança qualitativa, pois trazia preocupações sociais no campo da arquitetura. Isso provocou um novo desenho curricular, dando ênfase ao social. Segundo Maria Saleme de Burnichón, esse movimento partiu da FAU-UNC, e não de uma faculdade pertencente às ciências sociais por duas razões:

A primeira referia-se ao fato de que, pela primeira vez, em um curso como o da arquitetura, longo e originalmente pensado para a elite, entrava uma classe diferente: "o outro", o cabecita negra, uma

\footnotetext{
${ }^{47}$ Ibid., p.06

${ }^{48}$ Ibid.

${ }^{49}$ Martinez, Silvia A. 2000: 111-112.
} 
presença sensivelmente diferente, que trazia para o arquiteto a problemática social ${ }^{50}$.

A segunda razão referia-se, ainda de acordo com a professora Maria Saleme, ao fato de que, como em todas as faculdades, havia estudantes muito sensíveis aos movimentos mundiais, particularmente ao do maio francês. Os que participaram mais ativamente da construção do Taller Total eram politizados num sentido amplo, e não no estritamente partidário ${ }^{51}$. Por outro lado, como já foi dito, havia no campo disciplinar e seu ensino um debate latinoamericano e mundial que continha, entre outras questões, a revalorização da Bauhaus.

Para Facundo Ortega, sociólogo, professor do Taller Total, a FAU-UNC tinha-se tornado paradigmática como modelo revolucionário para outras faculdades. Isso, para ele, se devia a duas causas. Por uma lado, o fato do arquiteto urbanista oscilar entre ser intelectual, ou artista, ou profissional, ou técnico ${ }^{52}$.

Por outro lado, Ortega destaca que surgia em âmbito mundial um debate referente à problemática urbana. E que, nela, inseria-se 0 habitat, a ecologia, a sociologia urbana, que naqueles anos tinha-se convertido em tema de ponta. Os laboratórios de pesquisa (como eram chamados na França) mais importantes estavam trabalhando questões urbanas. A grande explosão desse tema relacionava-se, na visão do professor Ortega, com o clima revolucionário urbano. Córdoba, na época, não tinha faculdades de Antropologia nem Sociologia, apenas uma pós-graduação de qualidade questionável em Direito. Isso colaborou para que fosse a FAU-UNC a oferecer a alternativa de

\footnotetext{
${ }^{50}$ Burnichón, Maria Ester Saleme de, em depoimento a Martinez,Silvia A., 2000: 111. Na equipe de Pedagogia do Taller Total, Maria Ester Saleme de Burnichón destacava-se por sua reconhecida experiência. A Argentina recebeu, desde 1880, imigrantes europeus. A partir de 1930 outras migrações produziam-se, desde o interior do país para as grandes cidades. Nessas migrações, o componente de populações com ancestrais indígenas era muito forte, por isso o nome de cabecitas negras, segundo Silvia Martinez.

${ }^{51}$ A maioria das fontes consultadas coincide nessas afirmações.

${ }^{52}$ Ortega, Facundo em depoimento a Martinez, S., 2000: 112.
} 
enfocar o social, o que não se dava em outras faculdades, exceto em história. Era lá também o ponto de reunião de correntes políticas. Outro aspecto relevante era que Córdoba tinha tradição em trabalhar a questão urbana: a prefeitura dessa cidade foi, na época, uma das mais ativas em tema de Planejamento Urbano do país, o que coincidia com o auge internacional em urbanismo e sociologia e antropologias urbanas.

O professor Ortega ressaltou outro dado: as Bienais de arte patrocinadas pela fábrica de automóveis Renault, nas quais todo tipo de manifestação artística tinha expressão. Dava-se continuidade às atividades desenvolvidas pela Di Tella em Buenos Aires, configurando na prática um paralelo no qual tiveram participação central os arquitetos e estudantes de arquitetura. Em fins da década de 1960, as Bienais haviam desaparecido, e os professores que tinham sido importantes na formação de uma geração estavam, em sua maioria, fora do país. Num certo sentido, para Ortega, o Taller Tota/ recuperava essa geração perdida.

Completando o depoimento de Ortega, considero interessante resgatar a lembrança das peças satíricas de teatro apresentadas no palco do Auditório da FAU-UNC, na década de 1960 pelos arquitetos e professores J orge Bonino, Eric Ray King e Geraldo Ferradás, por meio das quais se faziam profundas críticas ao ensino universitário e às contradições da sociedade. Esses professores marcaram profundamente as idéias de várias gerações.

A análise dos depoimentos, assim como os documentos do Taller Total citados anteriormente, permite entender que se tratava de um projeto que, ao abrir o debate sobre arquitetura e urbanismo e seu ensino, visava redefinir o papel do arquiteto urbanista a partir de uma prática considerada social.

O conhecimento da realidade social era essencial à prática do arquiteto, para quem o aprendizado em e para esta sociedade requeria uma participação constante na configuração de seu processo de formação, 
o qual permitia desempenhar um papel ativo na construção da realidade sócio-econômica na que atua. Propunha-se a substituição de uma prática e um ensino fundado em um eixo técnico-estético por uma estrutura orientada para um eixo científico-social. ${ }^{53}$ Entendia-se como científico porque implicava o conhecimento real dos problemas referentes ao fazer específico do arquiteto. O social era percebido como inseparável do conhecimento da solução "efetiva, profunda e radical" dada aos requerimentos apresentados pela sociedade ${ }^{54}$.

Já no documento "Fundamentação de conteúdo e forma do Taller Total" apresentado em 1970 por ocasião da reunião fundadora, citada anteriormente, definia-se como objetivo geral do curso motivar e desenvolver nos alunos a capacidade de perceber o entorno e responder criativamente às necessidades, considerando o processo de mudança ${ }^{55}$.

\section{A fundamentação pedagógica}

Para cumprir esses objetivos, em especial os referentes à redefinição da arquitetura e urbanismo enquanto prática social, fazia-se necessário explicar e redefinir o ensino na FAU-UNC. Para isso, um dos itens do Livro Mostarda refere-se à fundamentação pedagógica, em que se afirma: "O Taller Total surge do compromisso compartilhado de docentes e alunos, frente a uma realidade impossível de ignorar"56. 0 Taller Total demandava uma atitude ativa, tanto de estudantes quanto de professores, possibilitando canais de comunicação amplos entre eles para a participação efetiva na análise dos objetivos nos quais a instituição estava inserida.

\footnotetext{
${ }^{53}$ Fontán; Novillo Corvalán, 1971: 08, grifo nosso.

${ }^{54}$ Ibid.

${ }^{55}$ Docentes e alunos, FAU-UNC, 1970, p. 04 apud Lamfri, 2007: 82.

${ }^{56}$ Fontán; Novillo Corvalán, 1971: 8.
} 
“O caráter transitivo dos papéis assegura o permanente intercâmbio dos mesmos em uma dinâmica onde ensinar e aprender são instâncias do mesmo processo" ${ }^{\prime 57}$.

\section{Objetivo pedagógico do Taller Total}

Na configuração em trama do TallerTotal' ${ }^{58}$ definiu-se como objetivo: "Projetar o aluno a uma realidade que abrange e, em certa medida, determina a ação atual e na qual deverá ser um membro ativo em uma co-gestão construtiva do conhecimento. [...] contribuir para a obtenção de uma transferência real. Instrumentá-lo em uma organização de pensamento e ação (método) para desenvolver nele a capacidade de enfrentar situações novas com apreciações exatas, com um mínimo de erro, como assim também o exercício de tomada de decisões" ${ }^{59}$.

Complementando o objetivo anterior, a equipe de Pedagogia e Psicologia do Taller Total afirmou (no texto "Alguns aspectos pedagógicos e psicológicos") que, na nova perspectiva de ensino, estava implícita uma mudança a respeito do que se entende por trabalho acadêmico, conceito de instituição e hierarquia de papéis (professor-aluno), assim como modificações na dinâmica das relações humanas ${ }^{60}$.

Em síntese, o Taller Tota/ significava:

a. uma perspectiva diferente na maneira de propor e resolver os problemas;

b. mudança de atitude no que se refere às relações interpessoais [...]. Trabalho grupal;

\footnotetext{
${ }^{57}$ Ibid: 09, grifo nosso.

${ }^{58}$ Fontán; Novillo Corvalán, 1971: 09.

${ }^{59}$ Ibid., grifo nosso.

${ }^{60}$ Equipe de Pedagogia e Psicologia do Taller Total, 1971, p. 01 apud Lamfri, 2007: 82.
} 
c. possibilidade de crítica constante de acordo com a natureza de sua metodologia;

d. participação do aluno na fixação de objetivos e hipóteses de trabalho.

e. revisão e redefinição dos papéis tradicionais de alunos e docentes. ${ }^{61}$

\section{Forma organizativa na $1^{\underline{a}}$ etapa do Taller Total (ano letivo 1970)}

Para colocar em prática os objetivos enunciados anteriormente, criou-se uma forma organizativa que permitisse a máxima versatilidade.

\section{0 - Currículo inicial ${ }^{62}$}

Inicialmente, a proposta dividiu-se em três áreas:

- Área de Projeto: atuava como coluna vertebral, agrupando as antigas cátedras de Composição Arquitetônica, Elementos de Arquitetura e Sistemas de Representação.

- Área Cultural: incluía a antiga cátedra de História da Arquitetura, a que se somavam Economia, Política, Psicologia e Ciências Sociais.

- Área Tecnológica: agrupava as antigas cátedras de Construções, Tecnologia dos Materiais, Instalações, Organização de Obras, Acústica e Lumicultura e Matemática.

Docentes e alunos, distribuídos segundo relações pedagógicas consideradas adequadas, constituíam uma unidade denominada Equipe de Trabalho, que se dividia em Comissões de Trabalho. Eram integradas por estudantes do 20 ao 6ำ nível da graduação, mas contemplava-se também a possibilidade de contatos dentro do mesmo nível, em determinadas circunstâncias.

\footnotetext{
61 Ibid.

${ }^{62}$ Fontán; Novillo Corvalán, 1971: 13 ;também Lamfri, 2007:. 85.
} 
Os diferentes níveis trabalhavam sobre o mesmo problema, diferenciando-se pelos graus de maturidade conceitual e prática com base na definição dos objetivos, que poderiam ser re-estudados no processo. Este deveria ser conduzido e avaliado pelos professores com base numa planificação aberta, para permitir uma operacionalidade flexível ${ }^{63}$.

O processo do Taller Total de Composição Arquitetônica realizado durante 0 ano letivo de 1970 foi complexo e não isento de dificuldades, muitas vezes permeado de acirradas e intermináveis discussões. Porém foi rico o suficiente para permitir, por meio de uma avaliação seriamente realizada, sua organização e reorganização.

Nessa avaliação, registrada no Livro Mostarda, foi marcante a presença da Equipe de Pedagogia e Psicologia, o que resultou numa mudança qualitativa da proposta curricular, na qual se passou de um ateliê vertical sob liderança da área de projeto a um ateliê onde o projeto derivava da ação interdisciplinar de todas as áreas, assumindo-se assim o papel original do Taller Total.

Considero, então, interessante determo-nos na auto-avaliação realizada pelas equipes de trabalho do Taller Totalsobre 0 ano acadêmico de 1970, na qual se afirma:

"Esta exposição está guiada pela convicção de que a análise crítica dessa experiência contribuirá para enriquecê-la [... $]^{\prime 64}$.

Como era previsível, devido à complexidade do processo e à diversidade das questões a serem tratadas, os objetivos ficaram pouco claros em vários momentos. No inicio, o desenvolvimento dos trabalhos foi um tanto anárquico e a constituição dos grupos bastante demorada e cheia de dificuldades. Isso porque o processo pressupunha mudanças em vários aspectos: o curso em si e seus papéis, sua inserção na universidade, o processo de ensino etc. Depois, tendo a Área de Projeto

\footnotetext{
${ }^{63}$ Fontán; Novillo Corvalán, 1971: 09-10.

${ }^{64}$ Fontám; Novillo Corvalán, 1971: 11.
} 
como eixo, elaborou-se uma programação que permitiu organizar as tarefas, fixando objetivos por nível e seus conteúdos para as três áreas. Porém manteve-se o caráter geral, assistematicamente às vezes, o que não permitia prever os momentos e conteúdos específicos. Os conteúdos foram muitas vezes ministrados do ponto de vista das pessoas, atendendo a situações isoladas e nem sempre nos momentos mais adequados. Isso se devia também à escassez de professores e à falta de integração das áreas no trabalho das equipes nos ateliês. Com algumas exceções, não houve integração de docentes das áreas culturais e tecnológicas às equipes estáveis dos ateliês, o que demandou um esforço quase exclusivo dos estudantes para a busca de respostas ou soluções.

A programação proposta não foi adotada por todos os ateliês (Equipes de Trabalho). As diferentes comissões de trabalho chegaram a resultados similares, mas não houve em todos os casos o mesmo grau de profundidade, talvez porque a generalidade das programações não permitiu fixar limites e tarefas precisas.

De todas as avaliações realizadas nas Equipes de Trabalho, surgiu a necessidade de superar a atomização produzida no início da nova proposta curricular. Isso determinou a realização de uma programação mais precisa referente a objetivos, organização de conteúdos, configuração das áreas de conhecimento, metodologias de trabalho e pautas de avaliação ${ }^{65}$.

O trabalho interdisciplinar foi, para o Taller Total, a única resposta possível à necessidade de conhecer a realidade complexa e multifacetária e atuar sobre ela. Por isso propunha-se a eliminação das cátedras como expressão do parcelamento (arbitrário e irracional) do saber, substituindo-as pelas áreas de conhecimento, que poderiam organizar os conteúdos com base em critérios científicos ${ }^{66}$.

\footnotetext{
${ }^{65}$ Fontán; Novillo Corvalán, 1971: 12-13.

66 Ibid.
} 
O caráter transitório do curso letivo de 1970 fez com que o trabalho ficasse centrado em Projeto, e as áreas Cultural e Técnica não conseguissem se inserir permanente e organicamente nesse período. Por isso, na minha visão, até agosto de 1971, a nova proposta manteve-se ligada à idéia implícita no seu nome inicial - Taller Total de Composição Arquitetônica - constituindo, ainda, um ateliê vertical.

Nesse primeiro ano de existência, definiu-se como área "a coordenação e a trama de conhecimentos tendentes ao estudo e interpretação de um objeto da realidade a partir de uma metodologia comum. Cada área mantém a especificidade de seu enfoque visando a articulação dos conhecimentos em volta de uma temática comum" ${ }^{\prime 67}$. Depois, com a reorganização, essas áreas passaram a denominar-se sub-áreas.

A nova forma de tratar os conteúdos das áreas de Tecnologia, de Projeto e Cultural evidenciou a necessidade de uma nova inter-relação coordenada e planificada para permitir estudar o problema proposto tendo em vista sua totalidade.

Postulava-se um trabalho de ida e volta entre as áreas e os ateliês que possibilitasse o reajuste dos objetivos das programações para adequar os conteúdos ministrados às necessidades da Equipe de Trabalho ${ }^{68}$. Era importante que houvesse uma articulação entre os objetivos gerais do Taller Total, os específicos de cada área e os objetivos por nível.

O tempo dedicado ao trabalho desenvolvido inter- níveis e a elaboração do marco teórico foi definido, no início, como um simples exercício. Porém, ao avaliar o trabalho por nível, constatou-se que os assuntos tratados na etapa de trabalho inter- níveis resultavam altamente proveitosos por oferecer uma visão abrangente do processo e revelar

\footnotetext{
${ }^{67}$ Ibid., p.13. As áreas, nesse ano, herdeiras da organização anterior da FAU-UNC, correspondem à organização em Departamentos realizada na FAU-USP a partir de 1962, que se manteve até agora e que foi também adotada pela FAU- SJC.

${ }^{68}$ Fontán; Novillo Corvalán, 1971: 14. Observava-se que muitas vezes, no Livro Mostarda, são usados como sinônimos equipe de trabalho e ateliê.
} 
as limitações do trabalho de projeto, tanto para os primeiros níveis, quanto para os últimos ${ }^{69}$.

A respeito dessas questões, Maria Saleme de Burnichón diz, em depoimento a Benjamim Elkin, que havia uma longa discussão nas equipes de Pedagogia sobre como equilibrar e quando produzir a separação em dois tipos de saberes: os gerais e os específicos. No caso dos alunos dos últimos níveis, as discussões e os debates derivavam do político-ideológico-econômico e o saber específico ficava quase que de lado.

Na equipe de Pedagogia, não sabíamos como ligar essas duas vertentes do saber e amarrar o nó final do projeto de arquitetura e urbanismo; falávamos com os professores para re-canalizar a atividade específica, porém no ateliê havia tanto para dizer, tudo era tão fértil, tanto para discutir que quando se entrava numa trama, nesse ritmo enlouquecido, não havia forma de deter o processo.

Ainda segundo Maria Saleme, a equipe Pedagógica percebeu que os arquitetos tinham necessidade de fazer o planejamento de todo o tempo que viria. Esse planejamento materializava-se em uma espécie de "lençóis" nos quais se fazia constar até o menor detalhe. Isso era o contrário do que a equipe de Pedagogia propunha, pois desde o inicio enxergava um planejamento geral do qual surgissem espontaneamente estímulos para incorporar novos questionamentos. Essa professora e pedagoga finalizou seu depoimento a Elkin, dizendo: "Foram anos muito [...] turbulentos, que tiveram a capacidade de uma grande força exposta. Não estávamos acostumados a isso [...], não havia outros caminhos e essa força passava por cima de nós"70.

\footnotetext{
${ }^{69}$ Burnichón, Maria Saleme de, em depoimento a Elkin, Benjamim, 2000: 164-165.

${ }^{70}$ Burnichón, Maria Saleme de, em depoimento a Elkin, Benjamim, 2000:164-165.
} 


\section{Pontos principais da avaliação do ano letivo de 1970}

Ao finalizar o ano letivo de 1970, as Equipes de Trabalho avaliaram positivamente o processo, pontuando as deficiências a serem superadas. Considerou-se que havia, nessa forma de ensino, uma contribuição a uma mudança qualitativa importante em relação ao aprendizado, gerando novas características em alunos e em docentes. Os estudantes, em especial os dos primeiros níveis, tinham aumentado sua capacidade de delimitar o tema proposto, ampliar as fontes de informação e utilizar as informações obtidas. Considerou-se que esses elementos eram um ponto de partida importante para desenvolver a análise crítica necessária ao exercício da arquitetura e urbanismo. Outra avaliação positiva foi a de que esse novo currículo havia permitido aos alunos dos diversos níveis a percepção geral do programa de todo o curso.

Apontaram-se como falhas possíveis de serem superadas:

- Os alunos, muitas vezes por não possuírem uma atitude autônoma e crítica frente ao trabalho acadêmico, tendiam a depender dos seus colegas dos cursos avançados, e esses assumiam muitas vezes 0 papel de docentes.

- Os docentes, em geral, tiveram dificuldade para remodelar sua própria imagem frente aos novos desafios, adotando condutas próprias da situação anterior.

Em conseqüência, verificou-se:

- Retraimento de alguns docentes por entenderem que 0 questionamento das formas e procedimentos tradicionais de ensino implicava perda da hierarquia docente.

- Alguns docentes deixavam de exercer uma função esclarecedora, se inserindo como um elemento a mais do processo dentro do ateliê pelo qual era responsável, isolando-se do Taller Total.

- Outros docentes entendiam que precisavam multiplicar-se como pessoas e como profissionais, instrumentalizar-se em outras áreas 
de conhecimento, para exercer funções em todas as comissões de trabalho de seu ateliê, deixando de ver que ele poderia configurarse com base em atividades simultâneas, diferente da aula magistral;

- Em relação às equipes docentes - forma organizativa que visava equilibrar tarefas, esforços e tempo disponível de cada professor -, observaram-se dificuldades no funcionamento como verdadeiro grupo de trabalho. As equipes docentes, em geral, preocupadas com os complexos problemas de cada equipe de trabalho (ou ateliê) em que atuavam, deixavam, muitas vezes, de estabelecer os contatos necessários para evitar a atomização do Taller Totale defazimentos em relação à sua programação.

- Muitos docentes dedicaram-se mais aos níveis avançados (IV e V), talvez porque esses compartilhavam e conheciam melhor os fundamentos e objetivos do Taller Total, o que contribuía para criar insegurança nos alunos dos primeiros níveis (I e II).

- Considerava-se desejável que o docente, enquanto parte integrante do processo, atuasse como retro-alimentador dos grupos e também como controle, propondo, entre outras coisas, tempos para cada tarefa e a programação das entradas das áreas de conhecimento.

\section{As transformações desejáveis e necessárias}

Ainda nessa avaliação, afirmava-se que a nova estrutura pedagógica do Taller Tota/ requeria do docente:

- Ministrar informações específicas e sinalizar problemas.

- Atender os limites dados pela programação.

- Procurar com os alunos as respostas possíveis à problemática abordada.

- Aprender a enriquecer sua pesquisa com os conhecimentos trazidos pelos alunos. 
Como contrapartida, requeria-se do aluno:

- Abandonar sua posição acomodada de submissão ao saber do professor para elaborar criticamente o que recebia, procurando, nas suas atividades, enriquecer-se e comprometer-se com seu próprio aprendizado.

Quanto à relação aluno-aluno afirmava-se que:

- 0 trabalho grupal expressa-se verdadeiramente no conjunto de indivíduos que se aproximam de seus objetivos com a dedicação, a visão crítica e a elaboração de cada um de seus integrantes, exigindo uma interação constante. Essa idéia de trabalho grupal difere da forma tradicional, pela qual, o grupo era concebido como um conjunto de indivíduos reunidos em torno de um trabalho comum, sob a direção do docente como líder formal.

$E$, quanto à relação docente-docente:

- A nova estrutura curricular e seu trabalho interdisciplinar demandavam transformações na relação docente-docente, já que todos deviam formar grupos de trabalho com os professores do Ateliê e/ou com os das Áreas de Conhecimento. 0 que era diferente do funcionamento nas cátedras, nas quais apenas os docentes de cada uma deveriam se relacionar entre si.

Em relação às avaliações, afirmava-se que:

- A estrutura pedagógica do Taller Total continha uma idéia de aprendizagem e de avaliação diferente da tradicional. Era importante avaliar o processo de aprendizagem em si e não somente a quantidade de informações apresentadas. Considerava-se o desenvolvimento da programação, seus reajustes, o crescimento e 0 amadurecimento dos alunos.

- A recomendação quanto à forma operativa do Taller Total foi:

- Combinar duas formas de trabalho de acordo com sua utilização mais adequada para cada etapa. Para o processo de projeto, as equipes de trabalho opinaram que era conveniente manter as 
comissões inter-níveis. Para a instrumentalização básica e específica ministrada por cada Área de Conhecimento, recomendava-se trabalhar por comissões por nível.

Por fim, concluiu-se que houve avanços no decorrer do ano, em especial por ter surgido, no ultimo período do ciclo letivo, uma programação que respondia melhor às expectativas de alunos e docentes. Os grupos conseguiram adquirir a dinâmica necessária para realizar as tarefas propostas, aprofundando e clareando os objetivos e os conteúdos do curso e permitindo a abertura de novos caminhos de pesquisa para a resolução do projeto arquitetônico ${ }^{71}$.

\section{Plano de estudos para 1971}

Estruturou-se o curso letivo de 1971 levando em consideração a avaliação descrita acima. Simultaneamente, foi designada uma Comissão de Docentes para elaborar um Plano de Estudos a ser aplicado a partir de 1972. Para recuperar os dias letivos perdidos, o curso de 1971 desenvolveu-se de acordo com as seguintes datas:

- 1 Período: 15 de setembro a 20 de dezembro de 1971.

- 2o Período: 15 de fevereiro a 15 de maio de 1972.

Devido à relação quantidade de alunos matriculados/ espaço físico, decidiu-se por dois turnos, de quatro horas cada um, à tarde e à noite. Em 1972 adotou-se uma medida de "emergência" (vigente ainda hoje), com a realização de três turnos (manhã, tarde e noite) de quatro horas cada $^{72}$. Essas mudanças ocasionaram perdas na carga horária acadêmica $^{73}$. Essas medidas se deram em conseqüência do reduzido orçamento destinado às universidades. Não por acaso as mobilizações estudantis e de docentes demandavam mais orçamento para as universidades como palavras de ordem.

\footnotetext{
${ }^{71}$ Fontán;Novillo Corvalán,1971: 18-19.

${ }^{72}$ Fontán; Novillo Corvalán, 1971: 22,23, 97.
} 
Produziu-se uma mudança na estrutura do Taller Total ${ }^{74}$ que significou um salto qualitativo na idéia do processo projetual. Consistiu na divisão da estrutura acadêmica em duas áreas, ambas com coordenadoria, que atendiam as diferentes modalidades do processo de aprendizagem:

- Área de Instrumentação;

- Área de Síntese.

Superava-se, assim, a velha divisão e decorrente disputa entre as disciplinas teóricas e práticas: todas passavam a ser teórico-práticas. As áreas de Projeto, Cultura e Tecnologia foram substituídas por seis sub-áreas que integravam tanto a área de Instrumentalização quanto a de Síntese. Porém, no processo de aperfeiçoamento foram novamente reagrupadas em três, sem que se alterasse a essência da nova estrutura.

\section{O novo Plano de Estudos}

Em fins de 1971 ficou pronto o Plano de Estudos para os anos seguintes $^{75}$. Ele inseria "o curso de Arquitetura e Urbanismo na estrutura funcional do Taller Total, compondo-o por meio da interação dinâmica de três sub-sistemas articulados: ciclos, áreas e subáreas" ${ }^{\prime 76}$.

O Plano propunha três ciclos obrigatórios para a graduação e um para a pós-graduação. Cada ciclo tinha em vista o processo completo com diferentes graus de aprofundamento.

\footnotetext{
${ }^{73}$ A carga horária anterior a 1970 era de 5.686 horas relógio e diminuiu com a distribuição em turnos para 5.220 horas relógio, aproximadamente.

${ }^{74}$ Essa mudança ficou estabelecida nas portarias 5/71, 6/71 e 7/71 registradas no Livro Mostarda. Porém, segundo Nora Lamfri, essa última portaria, de outubro de 1971, ao pôr em vigência as normas que conformavam o novo plano de estudos, estabeleceu que ele fosse elevado para aprovação do Conselho Superior, que o aprovou em caráter experimental ainda nesse mesmo ano. A aprovação definitiva esperou a gestão do Diretor Arquiteto Victor Soria, em 1972.

${ }^{75}$ Ficando as portarias números 5 e 6/71 transitoriamente complementares desse plano que emergiu da prática, realizado no Taller Total nesse ano.

${ }^{76}$ Fontán; Novillo Corvalán, 1971:44, grifo nosso.
} 
Os ciclos e os níveis apresentavam a seguinte relação:

- Ciclo Básico - Nível I

- Ciclo Médio - Níveis II, III e IV

- Ciclo Superior - Níveis V e VI

- Ciclo de Pós-graduação - 4 semestres.

Objetivos por ciclo:

- O objetivo principal do Ciclo Básico era fornecer elementos para a compreensão e resolução inicial do processo arquitetônico e urbanístico, desenvolvendo habilidades expressivas que permitissem comunicar a idéia projetual. Considerava-se necessário um tempo para a nivelação dos alunos, com base na diversidade das escolas de que provinham.

- O objetivo principal do Ciclo Médio era motivar a compreensão do processo de projeto e do seu problema tecnológico, partindo do levantamento critico da realidade.

- O Ciclo Superior previa a finalização do processo formativo com instrumentações relacionadas à prática profissional, visando encurtar a distância entre 0 estudante e 0 arquiteto ${ }^{77}$. A síntese comparativa apresentada a seguir mostra o processo de evolução do Plano de Estudos de 1971 a 1972, produto do debate democrático entre professores e alunos. Pode-se comparar também com o plano inicial descrito nas páginas anteriores.

${ }^{77}$ Ibid. 


\begin{tabular}{|c|c|}
\hline $\begin{array}{l}\text { ANO LETI VO DE } 1971 \\
\text { segundo a portaria no 6/ } 71\end{array}$ & $\begin{array}{l}\text { ANO LETI VO DE } 1972 \\
\text { segundo a portaria no 7/ } 71\end{array}$ \\
\hline Área de I nstrumentalização & Área de I nstrumentalização \\
\hline Área de Síntese & Área de Síntese \\
\hline $\begin{array}{l}\text { Sub-áreas (6) e seus campos de } \\
\text { conhecimento }\end{array}$ & $\begin{array}{l}\text { Sub-áreas ( } 3 \text { ) e seus campos de } \\
\text { conhecimento }\end{array}$ \\
\hline $\begin{array}{l}\text { - Morfologia } \\
\text { - expressão } \\
\text { - representação } \\
\text { - percepção e capacitação } \\
\text { - morfologia e organização espacial }\end{array}$ & \multirow{4}{*}{$\begin{array}{l}\text { - Projeto } \\
\text { - Morfologia } \\
\text { - Metodologia } \\
\text { - Equipamento } \\
\text { - Prática de obras }\end{array}$} \\
\hline $\begin{array}{l}\text { - Metodologia } \\
\text { - Técnicas de investigação } \\
\text { - Métodos de design ou projeto }\end{array}$ & \\
\hline $\begin{array}{l}\text { - Equipamento } \\
\text { - antropometria } \\
\text { - ergonomia }\end{array}$ & \\
\hline $\begin{array}{l}\text { - Práticas de obras } \\
\text { - Legislação } \\
\text { - Organização de obras }\end{array}$ & \\
\hline $\begin{array}{l}\text { - Ciências Sociais } \\
\text { - história crítica do habitat } \\
\text { - elementos de sociologia } \\
\text { - elementos de economia política } \\
\text { - antropologia cultural } \\
\text { - urbanismo }\end{array}$ & $\begin{array}{l}\text { - Ciências Sociais } \\
\text { - história crítica do habitat } \\
\text { - elementos de sociologia } \\
\text { - elementos de economia política } \\
\text { - antropologia cultural } \\
\text { - urbanismo }\end{array}$ \\
\hline $\begin{array}{l}\text { - Tecnologia } \\
\text { - Construções } \\
\text { - Instalações } \\
\text { - Estruturas }\end{array}$ & $\begin{array}{l}\text { - Tecnologia } \\
\text { - Construções } \\
\text { - Instalações } \\
\text { - Estruturas } \\
\text { - Condicionamento Físico do Meio }\end{array}$ \\
\hline
\end{tabular}


Esquema Funcional do Taller Total

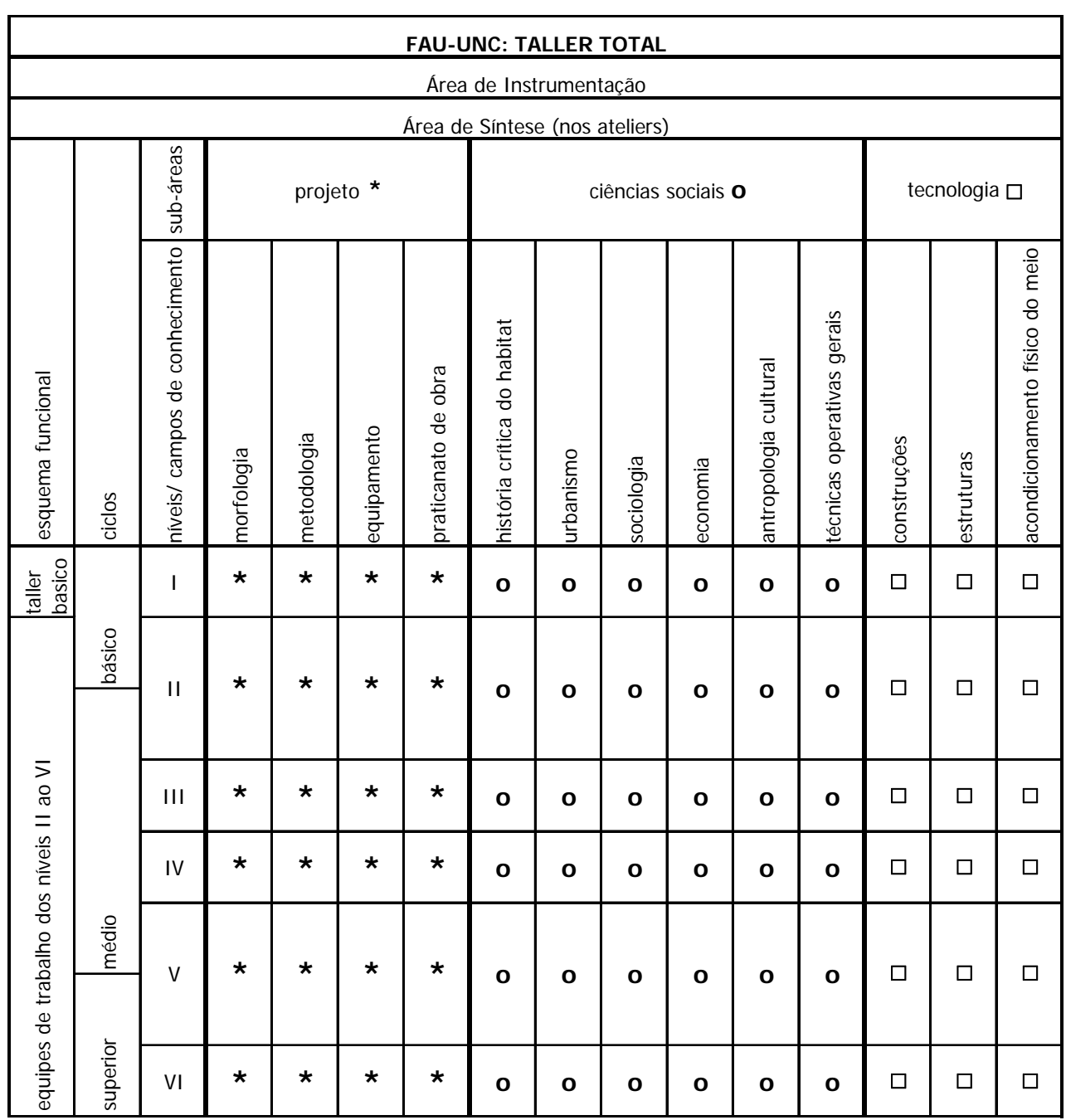




\section{Funções das áreas e sub-áreas}

\section{Área de I nstrumentalização}

A função dessa área era ministrar os conhecimentos básicos de cada campo de conhecimento visando cumprir os objetivos por nível e ciclo.

\section{Área de Síntese}

A função dessa área era permitir a aplicação, desenvolvimento, verificação, aprofundamento e reformulação dos conhecimentos básicos ministrados na Área de Instrumentalização, por meio do desenvolvimento do processo de projeto. Essa tarefa realizava-se interníveis e também nos níveis, de acordo com a programação geral do Taller Total.

A Área de Síntese, desenvolvida nos ateliês, significava a interrelação das sub-áreas para o tratamento da temática arquiteturaurbanismo como objeto multifacetário. Cada sub-área, porém, mantinha sua especificidade, apontando para uma articulação dos conhecimentos em torno de uma temática comum.

\section{Sub-áreas}

Cada sub-área era a coordenação do conjunto de conhecimentos que permitem o estudo e a interpretação de um objeto da realidade a partir de uma metodologia.

As sub-áreas deveriam também: assumir a pesquisa a partir de questões que emergiam do ateliê e de outros subsídios das próprias sub-áreas; preparar o material didático necessário; e implementar aos docentes dos campos do conhecimento dando apoio às suas atividades no ateliê. 
Foram definidos os objetivos gerais das sub-áreas do Taller Total e os das outras sub-áreas. Isso contribuía para gerar a interdisciplinaridade que nutria o Plano de Estudos.

Cada sub-área discutia, em reuniões de trabalho, os temas que seriam incluídos nos Planos de Estudo:

- objetivos por ciclo;

- objetivos por nível;

- conteúdos diferenciados por campos de conhecimento para cada nível.

Na sub-área de ciências sociais:

- os objetivos de seus campos de conhecimentos explicitaram-se de forma mais detalhada, provavelmente por se tratar de temas que o arquiteto urbanista da época estava começando a explorar. Talvez os novos docentes - em sua maioria antropólogos, sociólogos, historiadores, economistas e poucos arquitetos - desejassem fazer mais compreensível a função das ciências sociais.

- os conteúdos foram explicitados por nível e não diferenciados por campos de conhecimento ${ }^{78}$.

Por ser uma sub-área formada por professores de diversas graduações,entre eles,o antropólogo Facundo Ortega, a historiadora Beatriz Alasia e a socióloga Elsa Chanaguirre e o arquiteto Norberto Garimano, talvez tenha-se priorizado em seu debate a idéia de fazer um acordo entre os objetivos gerais e os conteúdos, em vez de dividi-los por campo de conhecimento, o que deu a essa sub-área maior ênfase interdisciplinar.

Dela fazia parte o campo de conhecimento História Crítica do Habitat, que substituía, em grande parte, as antigas cátedras de Integração Cultural e História da Arquitetura I, II e III. Entre os professores desse campo de conhecimento, a arquiteta Elsa Tânia Larrauri trabalhou com dedicação e entusiasmo durante o processo do Taller Total, formando

${ }^{78}$ Fontán; Novillo Corvalán, 1971: 26, 47 e 48. 
também os novos professores. Durante a ditadura militar iniciada em 1976, exilou-se no México e foi docente da FAU de Xochimilco, na qual contribuiu com a criação de uma experiência similar à do Taller Total ${ }^{79}$. Outro arquiteto, Oscar Moraña, docente desse campo de conhecimento, foi presidente da Federação Universitária de Córdoba ${ }^{80}$ e depois Secretário Acadêmico na FAU-UNC, durante o Taller Total. Exilado na Venezuela, a partir de 1976 exerceu a docência de Arquitetura, vindo a falecer posteriormente nesse país.

Também pertencia a esse campo de conhecimento a arquiteta Marina Waisman, professora de reconhecido saber, que naquele momento representava, na disputa de poder estabelecida no Taller Total, os setores que eram contra esse novo currículo. Renunciou à FAU-UNC em 1973 (já durante a gestão do arquiteto Osvaldo Bontempo), assumindo, em Buenos Aires, a direção da revista Summa, projetando-se internacionalmente. Mas não deixou de apoiar professores e alunos do Taller Total perseguidos pela organização paramilitar 3A (AAA) e pela repressão desencadeada durante o golpe militar de 1976. Muitos desses alunos e professores puderam sair do país com bolsas oferecidas por órgãos de pesquisa internacionais graças aos contatos dessa professora e arquiteta. Houve disputas, por vezes intolerantes, das partes envolvidas no Taller Total. Porém Marina Waisman, nos momentos políticos nos quais o terror se fazia presente, deixou de lado as diferenças político-acadêmicas em defesa das liberdades democráticas.

\section{I déias paradigmáticas no Taller Total}

A idéia de Habitat era um paradigma forte nas décadas de 1960 e 1970 na América Latina e no mundo, permeando o debate de arquitetura e urbanismo na FAU-UNC.

\footnotetext{
${ }^{79}$ Elkin, 2000: 117.

${ }^{80}$ Organização estudantil que liderou muitas das mobilizações estudantis.
} 
A discussão sobre esse tema tem antecedentes em 1953, no Congresso Internacional de Arquitetura Moderna ( $\mathrm{Cl} A M)$, no qual vários arquitetos, dirigidos por Alison e Peter Smithson e Aldo Van Eick (muitos dos quais formaram posteriormente o Team X), postulavam que não era mais possível pensar em urbanismo segundo a segregação funcional proposta em 1933 na Carta de Atenas ${ }^{81}$.

A noção de Habitat sustentava-se num conceito ampliado, que considerava não só a moradia, mas também os lugares de convívio e públicos - como domínios que possibilitavam a existência da vida em comunidade -, incorporando as questões da variedade cultural e também a idéia de pertencer a um lugar, definida como uma necessidade básica e emocional.

Para esses arquitetos, a proposta de Le Corbusier, em especial a Ville Radieuse, que refletia sua visão do modelo racionalista, transformava a cidade em um projeto calculado com base em uma equação analítica, apagando as inter-relações humanas criadas no processo de apropriação dos lugares.

Segundo Ana Claudia Castillo Barone, a redução da cidade à idéia de uma máquina formada por quatro funções deixava de lado a importância do processo histórico na construção dos lugares e de seus significados relevantes para a memória urbana.

As palavras de Aldo Van Eick expressam essa idéia:

“Uma árvore é uma folha como uma folha é uma árvore - a casa é a cidade e a cidade é a casa - a cidade não é cidade a menos que seja também uma grande casa - a casa não é casa a menos que seja também uma pequena cidade" ${ }^{82}$.

A forte influência do Team $X$ em grande parte dos professores e alunos da FAU-UNC, antes e durante o Taller Total, manifestava-se, entre

\footnotetext{
${ }^{81}$ Esse tema foi amplamente discutido por Ana Claudia Castilho Barone em "Team 10, Arquitetura como crítica”, 2000.

${ }^{82}$ Van Eick, 1966, apud Barore, Ana Claudia Castillo, 2002: 110.
} 
outras idéias, no consenso em relação à afirmação de Van Eick de que a obra não é apenas uma construção material e só se realiza com as pessoas.

Outro tema presente nas discussões no Taller Total, em especial nas sub-áreas de Ciências Sociais e de Projeto, era a relação entre arquitetura e urbanismo, entendendo-se que não deveria haver fronteiras entre eles, tal como afirmava Van Eick, entre outros arquitetos, ao dizer:

"Cada vez fica mais claro que o campo de trabalho criativo do arquiteto e urbanista não pode ser definido quantitativamente. A separação entre a escala de associação total em duas disciplinas é artificial e arbitrária. Entre a casa e a cidade há um campo de trabalho"83.

Em meados da década de 1960 e na de 1970, o debate de arquitetura e urbanismo na FAU-UNC incluía críticas ao funcionalismo realizadas por setores de professores e estudantes, com base em idéias filosóficas como as de Theodor Adorno. Esse autor comparou as idéias dos positivistas $^{84}$ com as dos arquitetos funcionalistas. Para Adorno, da mesma forma, eliminando os elementos não funcionalmente úteis de seu vocabulário, a arquitetura tornava-se subordinada à utilidade, incompleta por não considerar a importância dos aspectos não racionais no desenvolvimento dos processos sociais ${ }^{85}$.

\section{A discussão sobre a formação do arquiteto}

As preocupações com a formação do arquiteto aparecem com força nos congressos internacionais e latino-americanos, como foi dito em capítulos anteriores. Entre eles, o VII Congresso da União Internacional de Arquitetos (UIA) mereceu uma publicação da editora FAU-UNC em

\footnotetext{
${ }^{83}$ Van Eick desenvolveu este tema em “A história de uma outra idéia” . Revista Fórum, no. 7.. Amsterdam, 1959.

${ }^{84}$ Os positivistas excluíram da filosofia a sensibilidade poética alegando alcançar a neutralidade, porém distanciavam-se da verdade objetiva.

${ }^{85}$ Adorno, Theodor. "Funcionalism Today”, in LEACH, N. Rethinking Architecture, Londres e Nova York: Routledge ,(1997) apud Barone, Ana Claudia Castillo, 2002: 66.
} 
1970 que revela a forte referência desse congresso nas idéias desenvolvidas no Taller Total.

Também essas preocupações foram expressas no VIII Congresso Mundial da UIA, realizado em Paris em 1967, cujo tema central foi a formação de arquitetos em seus vários aspectos: geral, técnica e plástica, discutindo-se a conveniência ou não de uma coluna vertebral comum, do lugar do urbanismo, da definição de campos do conhecimento e de profissionais, entre outros assuntos ${ }^{86}$. Em maio de 1970 realizou-se a V Conferência Latino-Americana das Faculdades de Arquitetura (CLEFA) ${ }^{87}$ em Medellín, promovendo o debate em torno da temática da formação do arquiteto. Cabe aqui registrar algumas considerações e recomendações presentes também nos debates para o Plano de Estudos no Taller Total, especialmente nas reuniões das sub-áreas. Afirmava-se que "[...] a Universidade é parte da sociedade e dela depende. Que a Universidade profissionalizante alienou sua capacidade real de gerar conhecimento e cultura e, assim, não permitiu criticar a nossa realidade com os métodos das ciências. Que o predomínio das finalidades profissionais imediatas sobre o estudo das ciências na Universidade atual impediu o desenvolvimento criativo da pesquisa e $[. .$.$] o confronto de conhecimentos renovadores do$ pensamento. Isto é especialmente notório no campo das ciências sociais e das disciplinas e tecnologias do entorno humano $[\ldots]^{\prime \prime 88}$. Recomendou-se também nesse Congresso que:

“[...] as Universidades se organizassem sobre a base do conhecimento e não em volta das profissões, para o que se faz necessário a existência de uma total autonomia acadêmica, econômica e administrativa, que permitiria cumprir com plenitude social, sem limitações, restrições ou

\footnotetext{
${ }^{86}$ Lamfri, 2007: 73.

${ }^{87}$ Em nota de rodapé, Nora Lamfri (2007: 73) sugere ver também o "livro do arquiteto Jesus Aguirre Cárdenas: La Arquitetura in America Latina. Historia de La Conferencia Latinoamericana de Escuelas y facultades de Arquitectura publicado em 1996 pela Union de Universidades de América Latina, que contém a história da CLEFA assim como a origem de La União de Escolas e Faculdades de Arquitetura da America Latina (UDEFAL)”.
} 
dependências. Nessa nova organização da Universidade devem aparecer como áreas significativas e carregadas de conhecimento, previsão e criação do habitat e da ecologia humana: os campos do Design, da Arquitetura, do Planejamento Físico e do Urbanismo, essenciais para o desenvolvimento da sociedade atual e projeção de seu futuro" ${ }^{\prime \prime 9}$.

A sub-área de Projeto continha entre seus objetivos gerais:

- alcançar a realização integral do projeto de arquitetura e urbanismo;

- produzir a síntese dos diferentes campos de conhecimento relativos ao Habitat;

- verificar na prática a síntese elaborada no processo acadêmico ${ }^{90}$. Ao analisar os objetivos e conteúdos por nível e por campo de conhecimento nessa sub-área, notam-se algumas questões primordiais:

- forte preocupação com os métodos de projeto, incentivando o aluno a fazer análises críticas de metodologia de projeto com diversos enfoques: racionais, intuitivos, analógicos, programáticas e os de Christopher Alexander, Nuno Portas, entre outros;

- esforço em encontrar metodologias ancoradas no materialismo dialético e histórico, procurando fazer sua transferência para todo o processo do projeto, esclarecendo a etapa de passagem para a forma, que tradicionalmente constituía uma ruptura com as primeiras etapas do processo. Dito de outro modo, procuravam-se premissas para a formulação de uma nova teoria do projeto, que entendesse a obra arquitetônica e urbanística e seu processo de produção, incluídos no sistema econômico, cultural, político e social.

- desenvolvimento do estudo da relação entre a atividade humana produtora e as transformações do Habitat ${ }^{91}$.

A sub-área de Projeto ainda incluía conteúdos de paisagismo e planejamento urbano, distribuídos nos campos de conhecimento,

\footnotetext{
${ }^{88}$ Resoluções da V CLEFA de Maio de 1970, Medellín apud Lamfri, 2007: 75.

${ }^{89}$ Ibid: 76.

${ }^{90}$ Fontán; Novillo Corvalán, 1971: 61-62.

${ }^{91}$ Fontán; Novillo Corvalán, 1971: 62-73.
} 
garantindo sua inter-relação com os outros campos no processo do Taller Total na área de síntese.

A sub-área de Tecnologia tinha como objetivos gerais desenvolver a organização do pensamento e da ação (método) para fortalecer no estudante sua capacidade de enfrentar situações novas e de assimilar os aspectos derivados do progresso da ciência e da construção, atendendo às exigências do desenvolvimento industrial enquanto projeto e realização arquitetônica.

Os professores dessa sub-área afirmaram que "dada a complexidade [...] do domínio da tecnologia necessariamente deveu-se estabelecer uma divisão em campos de conhecimento [...] atendendo nesses as disciplinas que provinham do antigo currículo: Construções (materiais e sistemas); Estruturas e Condicionamento Físico do Meio"92.

Isso indica que não houve muitas mudanças nessa sub-área. Alguns dos professores, entre eles Rogério Lambertucci, abraçaram o novo currículo integralmente, esforçando-se para o diálogo com as outras áreas. Já outros, como afirmou um ex-aluno do Taller Total da FAUUNC, continuavam dando suas aulas como antigamente, ou seja, não estabelecendo nenhum tipo de comunicação com o conjunto dos ateliês e permanecendo em pequenas ilhas ${ }^{93}$.

Um membro da equipe de Pedagogia sinalizou que o diálogo com alguns professores engenheiros era difícil. Talvez devido à sua formação pragmática e com pouco contato com outras áreas, não viam a necessidade de construir conhecimentos de forma interdisciplinar e, em decorrência disso, não estavam dispostos a mudar o ensino tradicional fragmentado ${ }^{94}$. Isso talvez pudesse ser explicado pelo fato de que a sub-área de Tecnologia estivesse incluída num grupo disciplinar preocupado em

\footnotetext{
${ }^{92}$ Ibid.: 57.

${ }^{93}$ Depoimento de um arquiteto, ex-aluno do Taller Total da FAU-UNC, concedido a LAMFRI, 2007, p. 119.
} 
dominar o mundo físico e cujos resultados principais são as técnicas e os produtos, ou seja, com sua cultura orientada para papéis funcionais ${ }^{95}$.

\section{Equipes de Trabalho}

Organizaram-se doze Equipes de Trabalho com um total de 126 a 129 alunos em cada uma.

O Taller Básico permanecia separado, porém interligado por seus objetivos. A distribuição dos alunos por nível e a proporção de docentes por Equipe de Trabalho ficou estabelecida de acordo com o quadro abaixo ${ }^{96}$ :

\begin{tabular}{|c|c|c|c|}
\hline NÍVEIS & ALUNOS & $\begin{array}{l}\text { DOCENTES-ÁREA } \\
\text { SÍNTESE }\end{array}$ & $\begin{array}{l}\text { DOCENTES ÁREA } \\
\text { I NSTRUMENTALI ZAÇÃO }\end{array}$ \\
\hline II & 45 & 3 & \multirow{5}{*}{$\begin{array}{l}\text { NÚMERO DEFINIDO PELAS } \\
\text { SUB-ÁREAS }\end{array}$} \\
\hline III & $35 / 36$ & 2 & \\
\hline IV & 18 & 1 & \\
\hline V & $15 / 16$ & 1 & \\
\hline$\overline{\mathrm{VI}}$ & $13 / 14$ & 1 & \\
\hline TOTAL & $126 / 129$ & 8 & Relação 1 docente/ 16 alunos. \\
\hline
\end{tabular}

\section{Comissões de Trabalho}

Cada Equipe de Trabalho estava formada por cinco comissões interníveis. Cada uma delas deveria respeitar a seguinte proporção de estudantes por nível ${ }^{97}$ :

Nível II: $8 / 9$

III: 6

IV: 4.5

$\mathrm{V}: 3$

$\mathrm{VI}: 2 / 3$

\footnotetext{
${ }^{94}$ Entrevista de membro da Equipe de Pedagogia do Taller Total da FAU-UNC, concedida a Lamfri, 2007: 129-130.

95 Bescher, (1992) apud Lamfri, 2007: 128.

${ }^{96}$ Fontán; Novillo Corvalán, 1971: 23.
} 


\section{A função das Coordenadorias}

A Coordenadoria de Instrumentalização atuava como nexo entre as sub-áreas, verificava 0 andamento dos processos nos ateliês, coordenando e controlando a instrumentalização por nível, e apresentava à Secretaria Acadêmica as solicitações que o processo demandava.

A Coordenadoria de Síntese tinha as funções, entre outras, de elaborar, compatibilizar e verificar as programações das Equipes de Trabalho. Dessa coordenadoria participavam docentes e estudantes, eleitos democraticamente, representando cada Equipe de Trabalho.

\section{Consensos programáticos}

Assim eram definidos os acordos estabelecidos no seio da Coordenadoria Geral com os representantes de cada ateliê. Tratava-se de entendimentos baseados nas atividades acadêmicas, construídas a partir de um sistema de representação por Equipe de Trabalho.

Geralmente as discrepâncias geradas nos ateliês se explicavam, neste espaço, a partir dos planejamentos que realizavam os delegados, não isentos de relações conflituosas no interior dos mesmos e entre as diferentes Equipes de Trabalho ${ }^{98}$.

O cotidiano do Taller Total desenvolveu-se nos ateliês e o auditório (no qual antes eram ministradas as aulas teóricas) passou ser o lugar das assembléias. 0 ateliê como lugar físico favorecia o diálogo entre alunos e professores. Cumpriam-se ali, em conjunto e simultaneamente, todas as tarefas de disciplinas que até então não se tinham relacionado. Tentou-se que grupos de docentes de diferentes campos do conhecimento ministrassem aulas juntos, trocando opiniões entre si e com os alunos sobre os temas tratados. Surgiu assim a possibilidade de

\footnotetext{
${ }^{97}$ Ibid.

${ }^{98}$ Lamfri, 2007: 145-146.
} 
elaborar em conjunto idéias sobre esses temas com base em diferentes bibliografias, levando-se em conta novas vertentes de pensamento. Concordando com Elkin, levar essa forma de trabalhar não somente às disciplinas de um mesmo nível, horizontalmente, mas também interrelacionar atividades no sentido vertical, entre os diferentes níveis, foi uma utopia transformada em realidade. Isso contribuiu para que se unificassem as temáticas com diferentes graus de profundidade e complexidade. Essa forma de trabalho era o inter-nível, pilar da nova construção coletiva do conhecimento ${ }^{99}$.

Como já foi dito anteriormente, fazia parte do Taller Totalincluía-se a construção de inter-relações com grupos profissionais que provinham do campo das Ciências Sociais, como pedagogos, sociólogos, antropólogos, economistas, historiadores.

Cabe aqui estender as considerações sobre a equipe de Pedagogia incorporada ao corpo docente da FAU-UNC, devido ao seu papel fundamental na construção do novo currículo no processo do Taller Total.

\section{A equipe de Pedagogia}

Essa equipe era formada por um grupo de professores com diferentes trajetórias, mas unidos ante a idéia de uma pedagogia crítica. Isso contribuiu significativamente para o desenvolvimento de uma experiência nova em vários sentidos.

"A partir da intervenção desse grupo a elaboração da proposta teóricometodológica do Taller Tota/ resumiu o que havia de mais avançado em matéria de teoria pedagógica nesses anos"100.

\footnotetext{
${ }^{99}$ Ver Elkin, 2000: 68-69.

${ }^{100}$ Lamfri, 2007: 131.
} 
Tratava-se de pôr em prática o pensamento crítico pedagógico expresso numa proposta que apresentou desafios e exigiu muita criatividade, pois não havia outra experiência que fosse referência ${ }^{101}$. Maria Saleme de Bournichón era coordenadora da equipe de Pedagogia, que também contava com a participação de Alicia Carranza, Justa Ezpeleta, Lilians Fandiño, Marta Casarini, Lucia Garay,guilermo Villanueva, Lucy Jachewasky, Susana del Barco e Neolid Caballos. Contou-se com o assessoramento de Delich ${ }^{102}$, convidado para desenvolver temas no Taller Total do ponto de vista marxista, escutado com atenção pelos estudantes e docentes.

Maria Saleme de Burnichón, uma das máximas referências da educação na Argentina, foi demitida da Universidad Nacional de Córdoba, por ocasião do golpe de Organía em 1966. Exilou-se no México, onde foi pesquisadora da Universidad de Veracruz, em Xalapa, e realizou um importante trabalho de alfabetização de adultos em comunidades indígenas e escolas rurais; organizou também, nessa mesma universidade, a pós-graduação e participou da criação do Centro de Investigaciones Educativas ( $\mathrm{ClE}$ ).

Muitas referências consultadas coincidem ao afirmar que voltando do exílio, em meados dos anos 1970, Maria Saleme de Burnichón foi um dos pilares pedagógicos do "mítico Taller Total" da FAU-UNC e simultaneamente desenvolveu trabalhos de alfabetização em Salta (Argentina), em cuja Universidade dirigiu o Año Básico Común ABC, para ingressantes.

Em 1976, exilou-se novamente no México e só retornou para a Argentina, reassumindo seu cargo na UNC, onze anos depois. Declarou em várias oportunidades a respeito desses anos:

"As pessoas não querem saber o que se sabe, mas há silêncios que não se apagam [...] Foram anos escuros e difíceis de contar, tinha medo e

${ }^{101}$ Segundo membro da equipe de Pedagogia em depoimento concedido a Lamfri, 2007: 131. 
sabia que tinha, levava-o no braço o tempo inteiro, nem sequer ia embora em sonhos."

A experiência interdisciplinar tratava de formar equipes com profissionais que vinham de áreas em que não se valorizava a formação pedagógica para o exercício da docência. A tarefa prioritária da equipe de Pedagogia foi iniciar a construção de um espaço de diálogo e um vocabulário comum entre esses professores, ensaiando modos de trabalho conjunto - pois era impossível pensar a transformação das práticas pedagógico-didáticas proposta pelo Taller Total sem a participação da equipe de Pedagogia.

Essa equipe colaborava com a fixação de indicadores para as avaliações no decorrer da programação. Contribuía também com a implementação docente, com a programação e com as avaliações.

\section{Temas desenvolvidos}

No Taller Total o social estava presente nos temas abordados, o que pode ser revelado pela extensa bibliografia publicada pela FAU-UNC no período e resgatada por Elkin: Políticas Habitacionais, Saúde, Educação, Relação Arquitetura-Habitat, Critérios de Projeto nos Países Subdesenvolvidos, Formação Docente, etc ${ }^{103}$.

As reuniões da equipe de Pedagogia com os docentes incluíam leitura e discussão de textos, entre outros de Paulo Freire, cujas idéias eram compartilhadas por Maria Burnichón e sua equipe. Isso ajudava muitos dos docentes a construir uma articulação entre uma prática pedagógica dinâmica e interativa com uma prática participativa do arquiteto urbanista, que tem o usuário como seu destinatário.

\footnotetext{
${ }^{102}$ Delich, um dos participantes da revista Pasado e Presente, referência nos meios intelectuais cordobeses.

${ }^{103}$ Entre as publicações realizadas pela editora da FAU-UNC, referentes a esse tema encontram-se várias de Paulo Freire.
} 
Havia ciclos de palestras ministrados por sociólogos, antropólogos, historiadores e outros profissionais provenientes das Ciências Sociais, entre eles Baigorria, Delich e Aricó, reconhecidos intelectuais de Córdoba, os dois últimos participantes da revista Pasado y Presente. Faziam-se trabalhos de campo nas periferias, onde os estudantes descobriam a precariedade das moradias e da paisagem. A realidade das vilas de periferia, que eram apenas casas em série, impactava os estudantes da FAU-UNC, acostumados a projetar os edifícios como parte da paisagem, pensando nas áreas de convívio, contemplativas, de sombra e sol etc., inexistentes no cotidiano dessas populações ${ }^{104}$. Os estudantes, junto a muitos docentes, realizavam levantamentos nas favelas, analisando o modo de vida dos moradores, seus costumes, sua cultura, percebendo que "era muito pouco o que poderiam fazer a partir da arquitetura"105.

Muito citado pela maioria das fontes consultadas foi o tema abordado em 1974 por toda a FAU-UNC: Habitação e Equipamentos. Sua escolha se deveu ao fato de ter sido considerado um todo complexo, múltiplo e transformador como é o habitat humano. A Coordenadoria de Instrumentalização propusera um programa de seminários de informação docente com o objetivo de salvar, em alguma medida, a falta de programas de instrumentalização específica motivada pelo tardio acordo sobre o problema a ser desenvolvido durante o período letivo de 1974. Por outro lado, cada sub-área deveria definir um programa de conteúdos básicos compatibilizados por ciclo e nível, que seria incorporado à programação geral e desenvolvido e avaliado pelas equipes de trabalho e as sub-áreas.

A Coordenadoria Geral observou as características gerais dos produtos finais que deveriam realizar-se, levando em conta especialmente a formulação das considerações teóricas gerais e específicas a partir dos

\footnotetext{
${ }^{104}$ Depoimento de um membro da equipe de pedagogia concedido a Lamfri, 2007: 125.

${ }^{105}$ Depoimento de ex-estudante do Taller Total concedido a Lamfri, 2007: 125.
} 
quais cada equipe de trabalho deveria definir o tema e o problema a ser abordado. Para o trabalho em campo sugeriu-se atuar no meio urbano da cidade de Córdoba, não excluindo a possibilidade de atuar em outros lugares.

Foi proposto o seguinte esquema ${ }^{106}$ :

- Ciclo Básico - a) agrupamento básico de habitação (cinco a dez unidades) numa trama modulada contemplando circulações veiculares e de pedestres, equipamentos de uso diário (quiosques, padarias, etc.), redes de infraestrutura, áreas verdes, lazer para as crianças etc.; b) desenvolver uma célula com os detalhes técnicos construtivos.

- Ciclo Médio - módulo e trama habitacional inserido na proposta geral de habitat correspondente a cada equipe de trabalho que definiam a quantidade de habitações a desenvolver. Projetavam também os equipamentos, a infra-estrutura e áreas exteriores próprias à escala do problema. A ênfase estava nas soluções tecnológicas, sem que, no entanto, fossem descuidados os outros aspectos.

- Ciclo Superior - desenvolvia a estrutura geral habitacional e de serviços para um setor da cidade escolhido e sua relação com a estrutura urbana inserida.

\section{Carreira docente e concursos}

As profundas modificações que exigia o Taller Total fizeram com que 0 acesso e a permanência da docência fosse um dos temas a serem resolvidos. A portaria 6/71 tratou também da estruturação da carreira docente e da formatação dos concursos - o meio pelo qual eram contratados os professores, que em 1973 eram em número de 305; em 1974, 349, diminuindo para 318 em 1975, em decorrência da demissão

\footnotetext{
${ }^{106}$ Esquema sintetizado da publicação elaborada pela Coordenadoria Geral del Taller Total: Propuesta de Lineamientos para el Desarrollo Del Ciclo Acadêmico 1974. FAU-UNC, 1974: 02 apud Lamfri, 2007: 101-102.
} 
de 31 professores no contexto do avanço da direita peronista em Córdoba.

Em 1973, a relação docente-estudante era de 9,2; em 1974 era de 11,2; em 1975 cai para 10,7 $7^{107}$, o que demonstra, diferentemente do que ocorre hoje, uma preocupação com a qualidade de ensino, coerente com a etapa da universidade de massas.

O tema referente a Carreira e Formação Docente ${ }^{108}$ foi estudado em 1973 por uma comissão integrada pelas arquitetas Liliana Rainis, Sonia Terreno e Nilda Ramacciotti, encontrando-se entre as mais importantes contribuições do Taller Total. O documento apresentado por essa comissão destacou, entre outras questões, a importância da formação docente e criticava as hierarquias estabelecidas pela Lei Universitária vigente. Considerava o docente também como trabalhador, defendendo seu direito à estabilidade, porém entendia que essa questão dizia respeito a uma contradição inerente à organização do país e que sua resolução fugiu aos limites da FAU-UNC.

No início de 1972, o arquiteto Fontán renunciou a seu cargo e foi substituído pelo arquiteto Carlos Alberto Villada, que permaneceu somente três meses. Foi sucedido na diretoria por Victor Soria, em cuja gestão foi aprovado, no Honorável Conselho Superior (HCS), a estrutura do Taller Total e implementada a carreira docente, a partir de convocação de concursos públicos para cobrir 221 cargos docentes ${ }^{109}$. O arquiteto Osvaldo Bontempo iniciou seu mandato como diretor em junho de 1973. Sua gestão iniciou-se durante o governo eleito de Cámpora e suas primeiras resoluções foram reveladoras quanto à orientação que imprimiria; a primeira dessas resoluções apoiava-se numa portaria do Ministério da Cultura e da Educação pela qual se

\footnotetext{
107 “Síntese Estatística Universitária 1968-1975”, realizada pela Direção de Planejamento Departamento de Estatística - UNC (1976)

${ }^{108}$ Pela sua importância e complexidade, esse tema merece outra pesquisa, não cabendo aqui seu aprofundamento.

${ }^{109}$ Lamfri, 2007: 67; Elkin, 2000: 245-250. Os concursos públicos realizados não eram reconhecidos pelo Conselho Superior, sendo então esses cargos temporários.
} 
deixava sem efeito "toda separação de professores motivada por questões políticas", reincorporando, assim, os professores afastados em 1955, como também aqueles que foram discriminados nos concursos pelas mesmas causas ou simplesmente obrigados a apresentar sua renúncia. A outra resolução, que se apoiava na Lei de Anistia de 1973, incorporou os professores demitidos no ano de $1966^{110}$.

No começo de 1975, no contexto de "direitização" do peronismo (após a morte de Perón), Bontempo exilou-se devido às perseguições políticas, interrompendo seu mandato sem que nenhuma data apareça nos arquivos da FAU-UNC, segundo Elkin.

Seu sucessor foi o arquiteto J uan Rossi Fraire, que permaneceu no cargo por pouco tempo. Durante sua gestão pode-se dizer que o Taller Total entrou numa etapa de "esgotamento da experiência".

Para Elkin, a gestão do arquiteto Liliano Livi (iniciada em abril de 1975) deixa bem claro que a experiência do Taller Tota/ havia terminado. Seu fechamento definitivo e oficial se deu com violência física e a repressão dos participantes por ocasião do golpe militar de 1976.

${ }^{110}$ Rébora, Luis,1991: 79. 


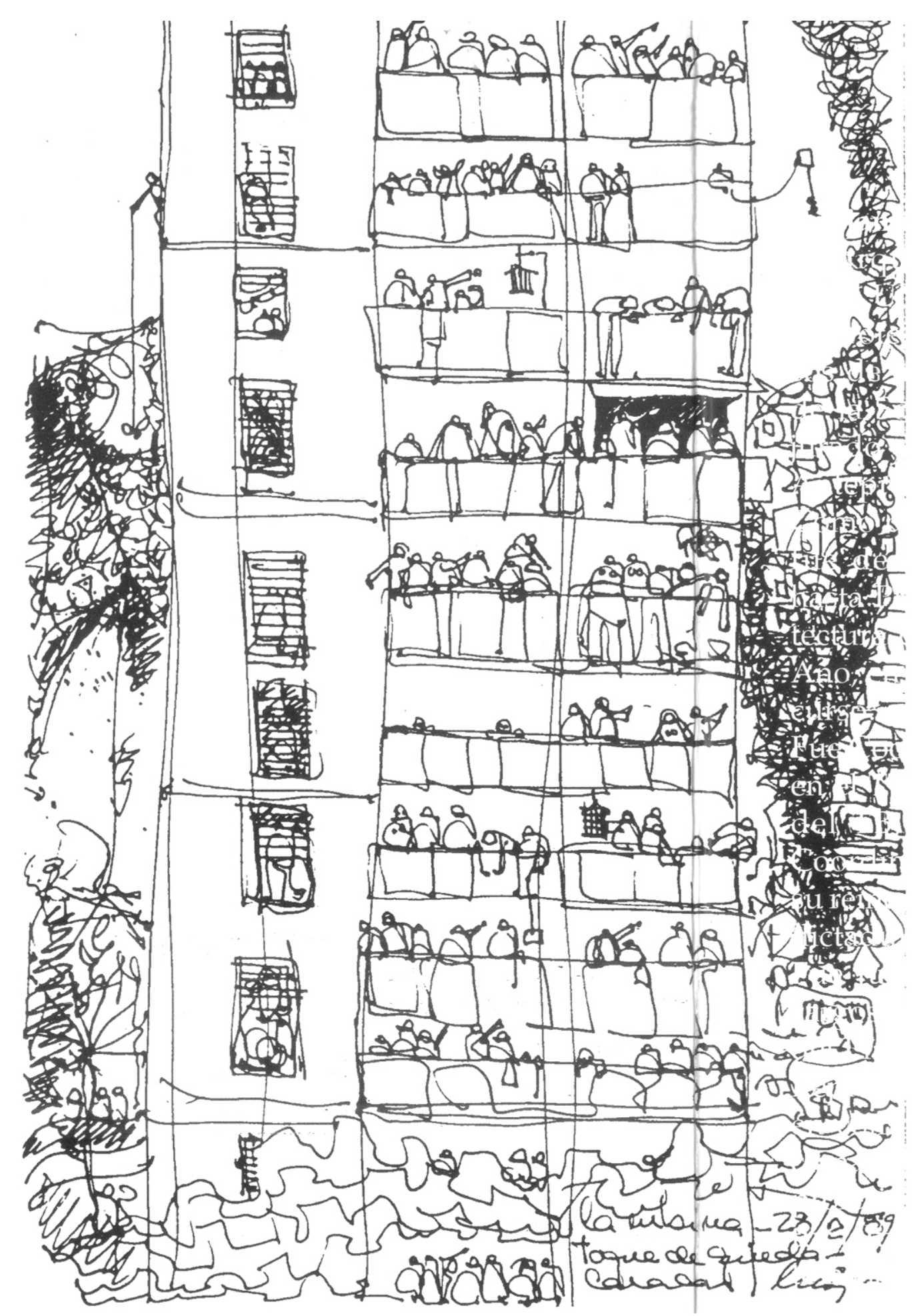

Ocupação da FAU-UNC.

Desenho de Luis Coccato, publicado por Elkin, B., 2000: capa. 


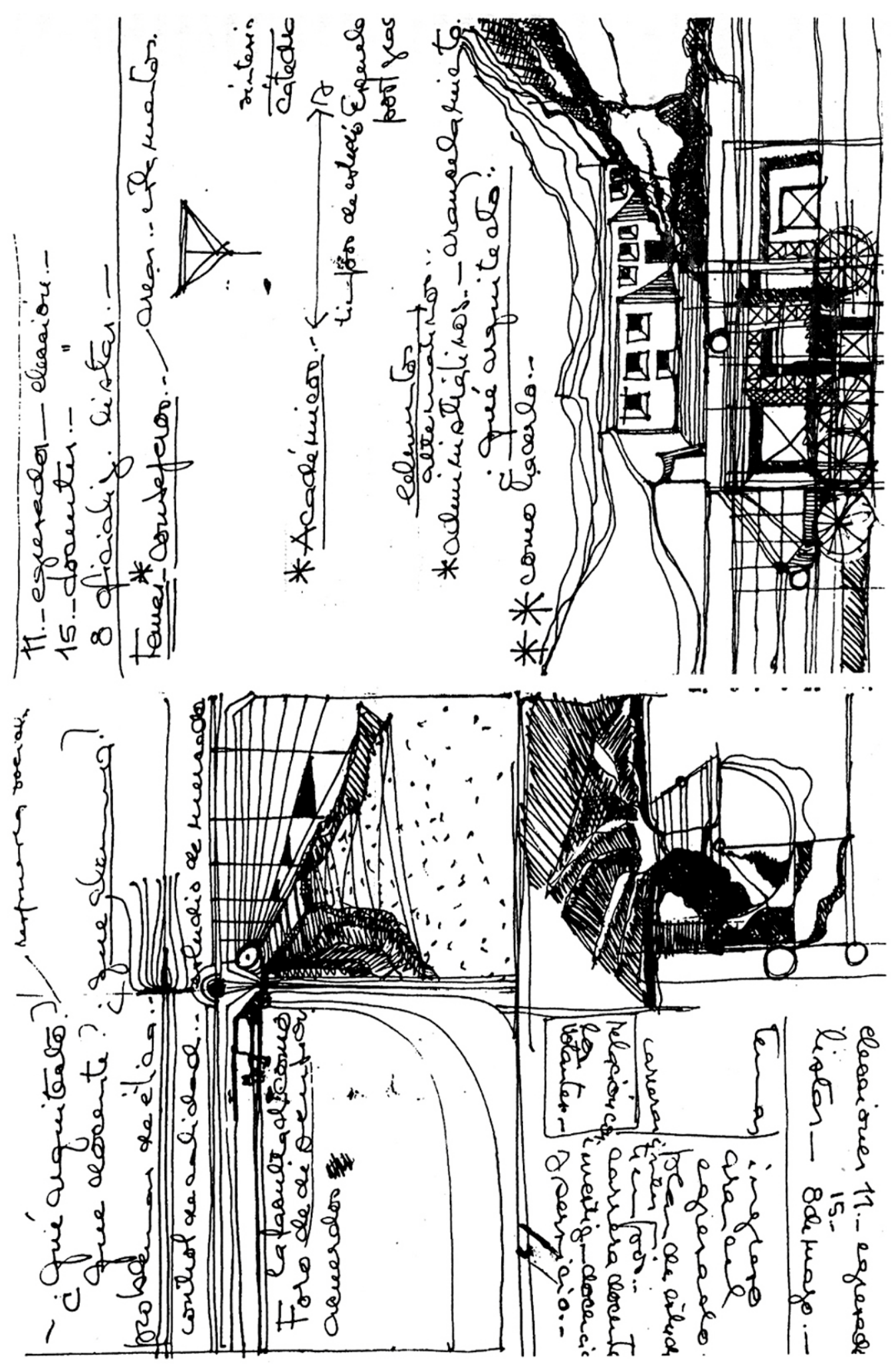

Desenho em reunião no Taller Total da FAU-UNC.

Realizado por Luis Coccato, publicado por Elkin, Benjamin, 2000: 86-87. 


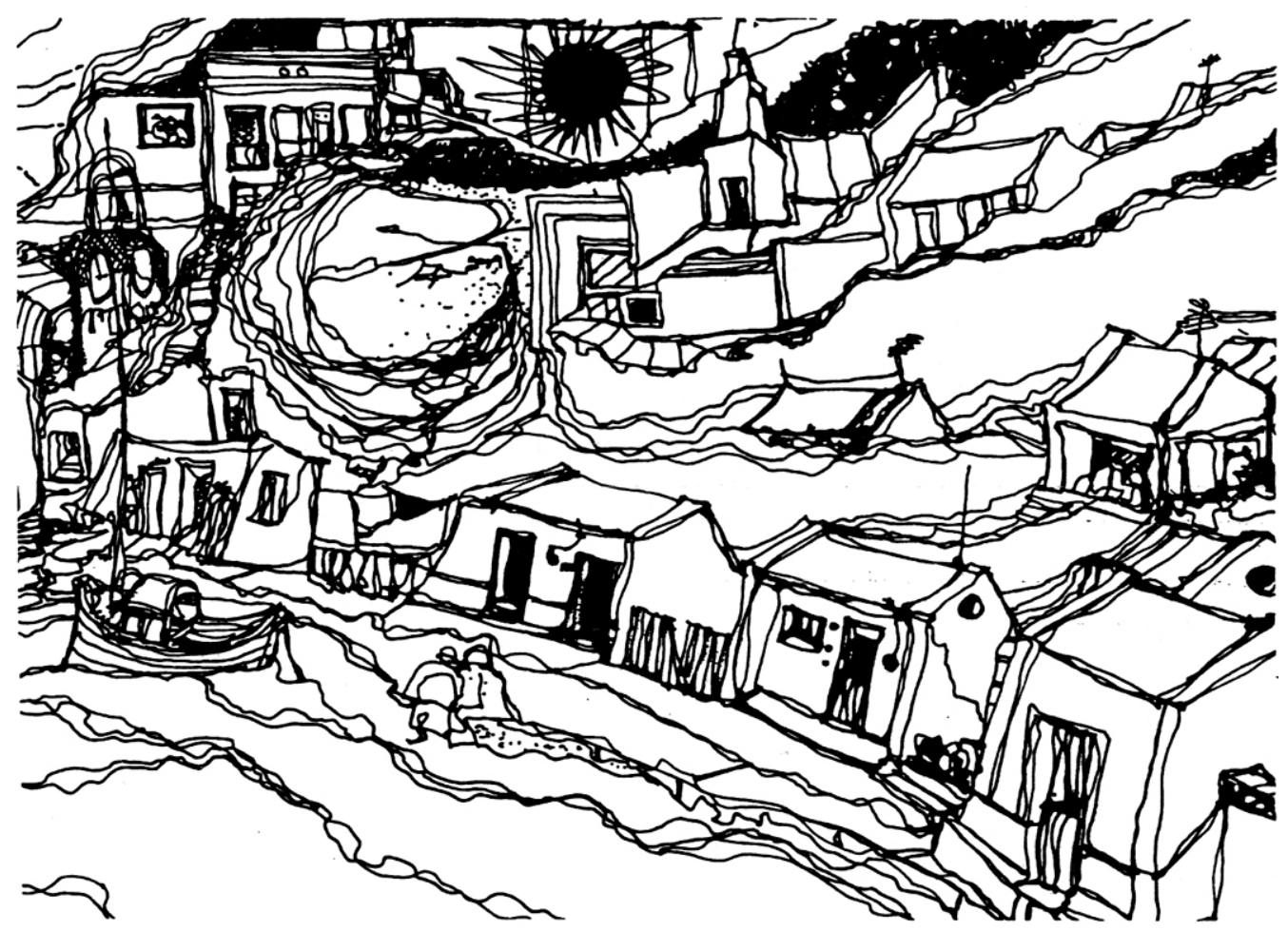

$$
\begin{aligned}
& \text { Fkilio trua m. Gu iro.. } \\
& \text { * AEQ . Fernaudo Grime. }
\end{aligned}
$$

Exílio de um professor da FAU-UNC.

Desenho do arquiteto e professor Fernando Gomez, publicado por Elkin, B., 2000: 110. 
Capítulo III

\section{FAU-SJC: O IPC - INSTITUTO DE PROJETO E COMUNICAÇÃO}

\section{Considerações iniciais}

A contenção inflacionária que se instaurou com o governo militar após 1964 refletiu-se, no campo da arquitetura e urbanismo, na retração da demanda de projetos e na redução de sua qualidade ${ }^{1}$.

Em algumas categorias profissionais, tal como a dos arquitetos, as formas de enfrentamento ao regime adquiriram maior visibilidade e por isso transformaram-se em emblemáticas.

A Universidade converteu-se num dos principais pólos de crítica e resistência ao governo e o meio universitário exigia uma ampla e radical reforma da instituição, procurando uma resposta política a um projeto de Universidade Nacional e mantendo posições correspondentes à fase de afirmação profissional, entre 1952 e $1965^{2}$.

Simultaneamente, a enorme massa de excedentes, calculada em 125 mil no vestibular de 1968, pressionava por uma mudança na política educacional, com demandas por mais verbas e vagas e por uma reforma universitária que atendesse a essas demandas. Porém, a resposta do governo foi, como já visto, a formulação de outra reforma universitária, em 1968, que atendeu aos interesses da expansão do capital e da política instaurada com o golpe de 1964, situação consolidada pelo acordo MEC-Usaid (United States Agency for International Development) ${ }^{3}$. Essa nova política educacional expressava

\footnotetext{
${ }^{1}$ Fernandes, Ari e outros, 1976: 126.

${ }^{2}$ Ibid.

${ }^{3}$ Fernandes, Ari e outros, 1976 (b): 03. Anexo VI.
} 
uma concepção empresarial ligada à economia de mercado, o que já foi discutido no capítulo I, parte II.

Fechada a UnB, por ocasião do golpe militar, e enfraquecida a FAUUSP, com o endurecimento do regime no final de 1968 e 1969, o Al-5 e a cassação de Vilanova Artigas e a aposentadoria compulsória de outros professores, o clima passou a ser amedrontador e desmobilizante. $\mathrm{E}$ nesse contexto se iniciou o processo de privatização do ensino superior, no qual se inclui a criação da FAU-SJ C.

Tendo participado intensa e ativamente como professora na FAU-SJ C, na FAU-Santos, na FAU-UnB e na EESC-USP, Mayumi Souza Lima elaborou, como fruto dessas experiências, um texto apresentado no $\mathrm{X}$ Encontro Nacional sobre Ensino de Arquitetura e V Congresso da Área ${ }^{4}$, no qual analisa os "mitos e impossibilidades reais nas universidades privadas e públicas". Considero interessante registrar aqui algumas das questões tratadas pela autora, que ajudarão a esclarecer o tema focado nesta tese. Mayumi W. Souza Lima foi um dos poucos arquitetos a entender o ensino de arquitetura inserido no processo geral da educação, assumindo-se como educadora, além de arquiteta, o que ainda hoje é difícil de ser compreendido nas faculdades de arquitetura. Realizou a tese de doutoramento na FE-USP, difundiu sua visão de ensino nos encontros, seminários e congressos de arquitetura, além de sua prática docente.

Segundo a autora, as condições de existência das universidades privadas e públicas, como também as características da demanda interna das escolas de arquitetura no Brasil tinham explicação e origem na maneira como as elites no poder conduziram as pressões populares pelo direito à educação e na forma como foi dirigida a política universitária.

\footnotetext{
${ }^{4}$ Lima, Mayumi Watanabe Souza, 1995: 59 - 60. Em 1973 e 1974 foi vice-diretora da FAUSJC.
} 
Mayumi Souza Lima relembra brevemente que esse processo está ligado à luta pelo direito à educação ginasial nos anos 1950, em especial em São Paulo, onde a carência de escolas e professores fomentava descontentamentos e reivindicações para ampliação na rede com o objetivo de assegurar vagas para todas as crianças em idade escolar. As pressões interferiam nas eleições de governantes, levando ao atendimento das reivindicações. Esse processo, afirma a autora, foi permeado pela falsa premissa que incidiu sobre todo o sistema escolar, incluindo as universidades: "democratização = má qualidade e elitização = boa qualidade" ${ }^{\prime 5}$.

A ampliação do direito à educação foi assim transformada numa concessão das elites, tanto pela necessidade de atender à maior escolaridade exigida pela industrialização, como para controlar e acalmar a pressão popular. As poucas exceções, abortadas, ressurgiram só nos anos $1980^{6}$.

A partir de 1971, o grupo escolar e o ginásio passaram a ser ensino básico de 10 Grau, sob a lei 5692. Porém, segundo a autora, a aplicação dessa lei não levou em consideração a realidade: poucos professores capacitados e instalações deficitárias. Conseqüentemente, muitas escolas funcionavam em porões e garagens, crianças sentavamse sobre caixotes, havia aulas em cinco ou seis turnos e eram convocadas às pressas professores leigos titulados de substitutos. A grande quantidade de escolarizados do 10 grau foi responsável pela pressão quanto à seqüência dos outros níveis, ou seja, pelo $2 \stackrel{0}{\text { grau }} \mathrm{e}$ mais tarde pela Universidade, porque as oportunidades de trabalho oferecidas pelo mercado eram insatisfatórias ${ }^{7}$, criando no imaginário popular a ilusão de que um diploma permitiria um melhor padrão de vida. Então, continua descrevendo Mayumi Souza Lima, o 20 grau funcionou nos vãos dos lugares destinados ao 1 o grau, nos horários

\footnotetext{
${ }^{5}$ Lima, Mayumi Watanabe Souza, 1995: 60. Grifo nosso.

${ }^{6}$ Ibid.

${ }^{7}$ Lima, Mayumi Watanabe Souza, 1995: 60.
} 
vagos das instalações conquistadas recentemente pelo ensino básico, nos cursos noturnos, com professores horistas, "verdadeiros caixeirosviajantes do ensino para completar salários aviltantes", lecionando para adolescentes que utilizavam carteiras e mesas inadequadas para seus corpos em crescimento.

A quantidade de alunos que chegavam a finalizar o $2^{\circ}$ grau era excessiva para as poucas vagas disponíveis nas universidades existentes; frente a essa situação, as elites, que já tinham controlado

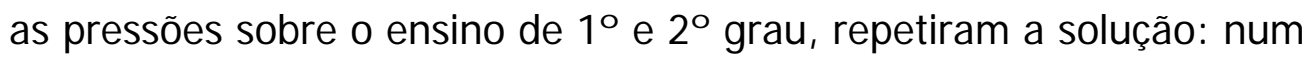
passe de mágica, o ensino universitário abriu-se para todos os candidatos, decretando a democratização do ensino universitário por meio de medidas ministeriais que fizeram frente às crises políticas de $1968^{8}$.

No entanto, tratava-se de uma falsa democratização, como se verá adiante. Eliminando o que se chamava de interferência estudantil na administração das escolas, a reforma universitária também instaurava mecanismos com o objetivo de frear a pressão social, como por exemplo a opção pela dispersão de escolas isoladas pelo interior, evitando assim a concentração de grandes conglomerados estudantis com os possíveis problemas políticos decorrentes disso?.

Nesse contexto, a nova política educacional do MEC era percebida também como uma esperada oportunidade de ampliar o número de cursos de arquitetura e urbanismo no Brasil. Muitos professores progressistas estavam descontentes com os caminhos pelos quais tinha enveredado o ensino nas escolas mais antigas (públicas ou privadas) e viam nesse processo de privatização novas oportunidades de criar cursos experimentais nos quais, sem entraves burocráticos, acreditavam ser possível pôr em prática modelos e propostas de ensino considerados mais avançados ${ }^{10}$.

\footnotetext{
${ }^{8}$ Ibid.

${ }^{9}$ Ibid.

${ }^{10}$ Fernandes, Ari, 1976: 129.
} 


\section{As novas FAUs privadas no estado de São Paulo}

Desde os anos 1960 vinha-se discutindo, tanto em âmbito nacional quanto latino-americano e mundial, o ensino de arquitetura, retomando e valorizando a experiência pioneira da Bauhaus.

Durante 0 ano de 1969, a partir de contatos prévios com instituições de ensino superior em municípios vizinhos à capital do estado de São Paulo, considerados pólos regionais, organizaram-se grupos de professores ${ }^{11}$ com o objetivo de viabilizar tais experiências, entre as quais as FAUs Santos, SJ C e Mogi das Cruzes.

Muitos dos cursos de arquitetura abertos no estado de São Paulo nessa época contaram com corpo docente formado por esses grupos de professores, que estavam empenhados na proposta de uma Universidade crítica em contraposição ao ensino empresarial postulado pela política governamental ${ }^{12}$.

Começava no ensino de arquitetura um novo período, com a proliferação das faculdades isoladas. Essas escolas eram vistas como laboratórios ideais para novas experiências de ensino, com estruturas operacionais revisadas e em que se rediscutiam as propostas políticas $^{13}$.

Porém, simultaneamente, a reforma oficial do ensino superior estava sendo implantada: "Nem a Universidade crítica, aberta, democrática, nem o modelo MEC-Usaid puro, mas uma mistura de concepções ecléticas sobre $o$ ensino superior variando de posturas positivistas a concepções tecnocráticas, passando pelas teses liberais de ensino, com ampla participação do enfoque da Universidade à luz da segurança nacional"14.

\footnotetext{
${ }^{11}$ Fernandes, Ari, 1976: 129 - também Bastos, Paulo, 2006, em entrevista concedida à autora. Esse arquiteto destaca o entusiasmo e empenho de todo esse grupo com que se trabalhou para abrir as novas escolas: noites sem dormir formatando novos currículos, reuniões e debates madrugada adentro e sem honorários.

${ }^{12}$ Fernandes, Ari e outros, 1976 (b): 9. Anexo II.

${ }^{13}$ Fernandes, Ari e outros, 1976 (b): 9. Anexo II. Também coincidem com essa visão: Lacaz, Guto,2007; Cury, Nabi,2007; Bastos, Paulo, 2006, entrevistas concedidas à autora.

${ }^{14}$ Fernandes, Ari e outros, 1976 (b): 09. Anexo II.
} 
Em 1969, aplicaram-se medidas de exceção tais que se calaram as reivindicações pelas quais lutavam os grupos organizados nas universidades brasileiras. Assim, a reforma universitária elaborada pelo MEC, emanada da ditadura militar, atendia na totalidade às necessidades da economia do ponto de vista do capital, incluindo-se as das empresas.

Como resultado dessa política, o ensino privado proliferou a partir dos anos 1970, como já visto; o número de faculdades aumenta desordenadamente, o que contribuiu para a queda da qualidade de ensino no Brasil, com o surgimento, também, de cursos caça-níqueis.

Esse contexto, porém, trazia em seu interior algumas contradições: não obstante serem tempos de ditadura militar, o sonho de um mundo melhor não estava silenciado. 0 ano de 1968 no seu significado na América Latina e no mundo ainda estava presente e a possibilidade de resistir e vencer as condições políticas adversas estimulava grandes setores sociais, entre eles, estudantes e intelectuais. Essas contradições possibilitaram aberturas, permitindo, até um certo ponto, o surgimento de propostas políticas de ensino que aspiravam à liberdade e à qualidade ${ }^{15}$.

A Faculdade de Arquitetura e Urbanismo de São J osé dos Campos, verdadeiro laboratório de ensino, não obstante os avanços e retrocessos que, de acordo com Guto Lacaz $^{16}$, colocavam o curso em crise a cada seis meses, porque o que se desejava não era atendido. O arquiteto e professor Hélio Duarte vincula a formação da FAU-SJ C à mudança da FAU-USP para a Cidade Universitária, no ano de 1969, considerando essa troca de endereço um marco na abertura ao ensino de massas. 0 aumento considerável de vagas, de 70 para 150, obrigava “a uma mudança quase radical nos processos de transmissão do conhecimento. Às modificações, dentro de cada turma para atender a

\footnotetext{
${ }^{15}$ Fernandes, Ari e outros, 1976 (b): 10. Anexo II.

${ }^{16}$ Lacaz, Guto, 2007, entrevista concedida à autora.
} 
grupos menores, seguiram-se alterações nos currículos a que se vieram juntar ainda novas contratações de professores"17.

No mesmo depoimento, Duarte caracteriza esse momento como de adaptação às novas condições, processo não isento de dificuldades, "penoso" mesmo. E lembra:

“Foi nesse período que, a convite e em colaboração com outros professores, participávamos da implantação daquela que deveria ser no tempo a melhor escola de arquitetura do país. Refiro-me à Faculdade de Arquitetura de São J osé dos Campos, infelizmente fechada depois, e para sempre, por desacertos entre professores e alunos de um lado e a Fundação de outro"18. O professor acrescenta que espera ver retomado, no futuro, o sentido dessa proposta de ensino.

Por ocasião do IX Congresso Brasileiro de Arquitetos, realizado em 1976, foi apresentado o documento 'Prática-Investigação: um processo de trabalho em São José dos Campos ${ }^{\prime 19}$. Segundo seus autores, os novos cursos em implantação apresentavam características similares, tais como:

- Tentavam absorver a demanda excedente dos vestibulares dos cursos ou faculdades mais tradicionais.

- Eram mantidos por entidades privadas com fins lucrativos, mesmo que, na maioria dos casos, seus estatutos afirmassem 0 contrário.

- Constituíam escolas isoladas.

- O corpo docente inicial era o mínimo suficiente para 0 funcionamento da primeira série, e ampliava-se na medida da necessidade de cada ano.

\footnotetext{
${ }^{17}$ Duarte, Hélio, Depoimento: 06, in Cadernos Brasileiros de Arquitetura $\mathrm{n}^{\circ}$ 8.,s/data.

${ }^{18}$ Ibid. Também Bastos, Paulo, 2006, em entrevista concedida à autora.

${ }^{19}$ Os autores desse documento são: Fernandes, Ari Vicente, arquiteto; Nogueira, Cristina Wickerhauser, estudante; Morita, Horacio M., arquiteto; Freitas, Ives de, estudante; Maffezoli, Lineu Carlos, economista; Oliveira, Márcio Romero de, estudante; Cunha, Maria C. Pereira, historiadora; Nucci, Marizabel Penteado, estudante; Nador, Mônica P., estudante; Fernandes, Yara Vicentini, arquiteta.
} 
- A maioria dos professores, residentes na capital, viajava semanalmente para dar aulas na escola, geralmente localizada em uma cidade próxima.

- As mantenedoras sabiam muito pouco do ensino de arquitetura, adaptando o novo curso superior aos modelos convencionais de outros mais tradicionais.

- Geralmente utilizavam prédios já existentes, construídos para outros fins, sem as adaptações necessárias.

- Comprovada a lucratividade do curso, após alguns anos de funcionamento começavam a ser realizados pelas mantenedoras os considerados 'investimentos de longo prazo', tais como infraestrutura administrativa, equipamento básico de oficinas e laboratórios e instalações especiais mínimas ${ }^{20}$.

Na FAU-SJ C, somavam-se a essas características gerais, alguns aspectos particulares:

- A economia industrial em expansão do Vale do Paraíba e seu contexto regional eram um estímulo à implantação do curso.

- Um possível convênio cultural entre a mantenedora e a prefeitura local resolveria o problema dos recursos para o investimento inicial e daria emprego aos estudantes.

- O corpo docente inicial elaborou uma proposta de organização curricular baseada em suas experiências de ensino anterior, na UnB (tanto entre 1962-64 quanto em 1968) e na FAU-USP ${ }^{21}$.

Se por um lado não existiam os entraves burocráticos das universidades tradicionais, sobretudo das públicas, por outro lado apresentava-se outro entrave, o empresarial, que aspirava ao lucro máximo e imediato com um investimento reduzido ao mínimo possível para a subsistência

\footnotetext{
${ }^{20}$ Fernandes, Ari e outros, 1976: 129. Também, Mayumi Souza Lima, 1995. Observação: essas características se mantêm quase na íntegra até hoje.

${ }^{21}$ Fernandes, Ari e outros, 1976: 129. Também, Mayumi Souza Lima, 1995 e Bastos, Paulo, 2006, em entrevista à autora.
} 
do curso $^{22}$ (pode-se dizer que estas últimas características mantêm-se até hoje na maioria das escolas particulares).

\section{I mplantação da FAU-SJ C e sua relação com a cidade de São José dos Campos}

A instituição mantenedora da FAU-SJ C foi a Fundação Valeparaibana de Ensino (FVE). Existente desde 1963 em São J osé dos Campos, a fundação congregava várias faculdades e estava interessada em se transformar em universidade.

Cabe aqui registrar brevemente alguns aspectos do Vale do Paraíba e da cidade de São J osé dos Campos, onde se instalou a FAU-SJ C, para entender melhor o processo de ensino de arquitetura e urbanismo nela desenvolvido.

Os núcleos urbanos estabelecidos no Vale do Paraíba desenvolveramse, durante quatro séculos, junto às margens do Rio Paraíba e somente no século XX expandiram-se no sentido leste-oeste, em relação aos eixos do rio, das rodovias e da ferrovia ${ }^{23}$.

O Vale do Paraíba assistiu a diversos ciclos de crescimento e declínio econômico, especialmente no período da economia cafeeira. Seu crescimento populacional, urbano e econômico, sobretudo após os anos 1940, inclui-se na lógica da reprodução do capital, processo que se vinculou às formas e diretrizes de ocupação territorial que permitiram novas dinâmicas de desenvolvimento econômico e expansão urbana. Foram determinantes para a orientação do crescimento industrial e populacional do vale paraibano a construção da rodovia Presidente Dutra e a instalação da indústria siderúrgica de Volta Redonda ${ }^{24}$. Essa urbanização esteve historicamente relacionada às mudanças do sistema produtivo e às intervenções do governo federal nos eixos de

\footnotetext{
${ }^{22}$ Ibid.

${ }^{23}$ Ibid.

${ }^{24}$ Ibid.: 75 .
} 
transporte, tanto inter-estaduais quanto inter-municipais, tais como a estrada de ferro Central do Brasil, no século XIX, e as rodovias Presidente Dutra, Dom Pedro I, Ayrton Senna e Carvalho Pinto, a partir dos anos $1950^{25}$.

O processo de urbanização, inclusive no período desenvolvimentista, entre 1956 e 1961, foi caracterizado por grandes investimentos estatais com o objetivo de criar condições para a produção de bens de consumo duráveis e de uma infra-estrutura urbana e regional que possibilitasse a circulação de pessoas e mercadorias e a geração de energia ${ }^{26}$.

Nesse contexto, o processo de urbanização do Vale do Paraíba, inserido no eixo de deslocamento do capital entre São Paulo e Rio de Janeiro e na substituição das atividades agropecuárias pelas industriais, caracterizou-se pela tendência à concentração de capital e de população em determinados municípios ${ }^{27}$.

A urbanização no Vale do Paraíba, e em particular em São J osé dos Campos, a partir da década de 1970, revela o modelo econômico baseado na concentração de renda e riqueza e na formação do 'exército de reserva', fundamentais para a implantação do parque industrial, para a reprodução do capital investido e para a lucratividade. Esse processo se relaciona com as tendências de desconcentração da estrutura produtiva ao redor da cidade de São Paulo, em direção às regiões próximas cuja infra-estrutura possibilitou a consolidação de novos pólos de desenvolvimento. ${ }^{28}$ É o caso da cidade de São José dos Campos, que se situa entre as serras do Mar e da Mantiqueira, perto dos portos de São Sebastião e de Santos e das praias do litoral norte.

As origens dessa cidade remontam à Aldeia do Rio Comprido, fazenda jesuítica formada no final do século XVI ${ }^{29}$. Entre 1930 e 1950, São José dos Campos teve uma fase chamada de 'sanatorial', já que, devido ao

\footnotetext{
${ }^{25}$ Ibid.: 70-71.

${ }^{26}$ Reschilian, Paulo Romano, 2004: 89.

27 Ibid.

${ }^{28}$ Ibid.: $72-74$.
} 
clima, era procurada principalmente por doentes de tuberculose; em 1935 foi transformada em Estância Climatérica e Hidromineral ${ }^{30}$.

Dois fatores contribuíram para a consolidação da economia industrial da cidade: a instalação do Centro Técnico Aerospacial (CTA) em 1950 e, no ano seguinte, a inauguração da rodovia Presidente Dutra. Em decorrência da industrialização, o processo de urbanização da cidade acelerou-se, chegando a ter um crescimento demográfico expressivo ${ }^{31}$. O final da década de 1960 e a década de 1970 constituíram um período particular do desenvolvimento industrial no Brasil, caracterizado, como em outros países periféricos, pelo surgimento de plantas industriais desenvolvidas nos países centrais, ou, dito de outra forma, pela abertura de filiais de indústrias consolidadas nesses países centrais ${ }^{32}$. Desenvolveram-se então políticas governamentais incentivando a desconcentração industrial, favorecendo o crescimento de cidades médias e a formação de pólos regionais ${ }^{33}$, como é o caso de São J osé dos Campos.

Nesses anos, o crescimento econômico, especialmente no interior dos estados de São Paulo, Minas Gerais e Rio Grande do Sul, teve origem em grandes investimentos estatais em infra-estrutura energética e de transporte ${ }^{34}$. Segundo Shiffer, o capital industrial paulista controlava essa desconcentração econômica, o que, por um lado, trazia o aumento da acumulação intensiva e, por outro, contribuía para o enfraquecimento do poder dos sindicatos de São Paulo, que se vinham fortalecendo desde $o$ início dos anos $1970^{35}$.

\footnotetext{
${ }^{29}$ Reschilian, Paulo Romano, 2004.

${ }^{30}$ Ibid. também , Silvia Vitale, 2007, pesquisadora do Vale Paraibano, em entrevista concedida à autora.

${ }^{31}$ Vitale, Silvia, 2007, em entrevista concedida à autora.

${ }^{32}$ Lucchese, Maria Cecília, 2004: 18.

33 Ibid.

34 Ibid.

${ }^{35}$ Shiffer, Sueli, in Lucchese, Maria Cecília, 2004: 19.
} 


\section{Conversações iniciais para a abertura da FAU-SJ C}

Desde o início da criação da FAU-SJ C, sua mantenedora, a Fundação Valeparaibana de Ensino, manifestava um desconhecimento didático e técnico quanto à formação do arquiteto. Sua orientação geral era criar escolas com o mínimo de despesas e o máximo de lucros, com a administração estritamente necessária; assim, a fundação solicitou a um corpo de professores a elaboração do Regimento Interno e do projeto pedagógico da FAU-SJ C, iniciando conversações com Vicente Bicudo, arquiteto, designer e professor, para ocupar a diretoria do novo curso ${ }^{36}$.

Considero importante explicar brevemente a trajetória desse arquiteto, inserida no processo de industrialização das décadas de 1950 a 1970, nas quais o design encontrou possibilidades de realização estética e tecnológica. É necessário lembrar que, com a inauguração de Brasília, as indústrias que utilizavam o design brasileiro cresceram expressivamente, já que a nova capital, além de abrir oportunidades no mercado interno, configurou-se numa vitrine internacional ${ }^{37}$.

Nesse período "começou a circular pelas estradas do país o que seria uma inovação mundial: o ônibus com sanitário a bordo, poltrona-leito e cabine fechada para o motorista - um projeto com a marca Tepperman, elaborado pela equipe chefiada pelo designer Vicente Bicudo" ${ }^{38}$, também responsável pelos bancos aéreos para passageiros do metrô de Washington, São Francisco e Los Angeles e pelo projeto da Catedral de Loanda, no Paraná.

Paulo Bastos, em 1969, foi convidado por Vicente Bicudo, para organizar, junto com Siegbert Zanettini, a Faculdade de Arquitetura de São J osé dos Campos. Ele aceitou o convite pela oportunidade de fazer

\footnotetext{
${ }^{36}$ A opção por arquitetura, na visão de Regina Cardarelli, ex-aluna da FAU-SJC, foi influenciada, entre outros motivos, pela existência na época de mobilizações estudantis por mais vagas nessa área (Cardarelli, Regina, 2006, em entrevista concedida à autora. Pertenceu à primeira turma da FAU-SJC).

${ }^{37}$ Leal, Joice Joppert, 2005: 13, in https://portal.br/tec/imagens/revistas/012_015_marcos_do_design_brasileiro_SEG.pdf
} 
uma escola diferente, sem os vícios da FAU-USP, que, na sua visão, naquela época manifestava uma tendência a "se enquistar, se engessar, convencionalizar-se nos trabalhos" ${ }^{\prime 39}$.

\section{O vestibular}

Para Hélio Duarte, "os exames vestibulares ali [na FAU-SJ C] realizados naquela ocasião foram realmente um paradigma. A Faculdade foi fechada, os professores, entretanto, haviam lavrado um tento magnífico" ${ }^{40}$.

O vestibular foi preparado, segundo Paulo Bastos, mais com o intuito de perceber o grau de sensibilidade e nível cultural dos alunos que a quantidade de informações que possuíam, sobretudo as de caráter politécnico, como era a tônica dos vestibulares nas FAUs tradicionais. As provas focadas na arquitetura não eram de múltipla escolha e os conhecimentos de português eram avaliados na prova de história, que dava ênfase a arte e arquitetura. Da elaboração das provas participaram também profissionais da área de comunicação visual ${ }^{41}$.

\section{Proposta inicial: o I PC}

Passado o vestibular, o curso teve início dentro da proposta de implantar, de forma gradual, um instituto - que veio a receber o nome de Instituto de Projeto e Comunicação (I PC) - similar ao Instituto

\footnotetext{
${ }^{38}$ Ibid.

${ }^{39}$ Bastos, Paulo, 2006, em entrevista concedida à autora. Paulo Bastos, arquiteto formado em 1959 na FAU-USP, foi professor da FAU-Mackenzie, demitido em 1964 e readmitido em setembro do mesmo ano, por pressão de greve estudantil. Voltou a ser demitido em 1968. Foi indicado pelo IAB junto a Miguel Pereira, Newton Braga e Liberal de Castro para reabrir o curso de arquitetura na Universidade de Brasília, cumprindo um papel preponderante.

${ }^{40}$ Depoimento de Hélio Duarte in Cadernos Brasileiros de Arquitetura ${ }^{\circ}$ 8: Siegbert Zanettini. ${ }^{41}$ Alguns ex-alunos entrevistados, entre eles a arquiteta Regina Cardarelli, lembram que as provas, comparadas às da FAU-USP no mesmo período, estavam mais bem estruturadas e mais focadas em Linguagem Arquitetônica. Opinião similar foi expressada pelo arquiteto Luiz Ackel, ex-aluno da FAU-Santos nesse período, que diz que os vestibulares de SJC e Santos em 1970 eram muito similares entre si, e, em relação ao da FAU-USP desse ano, "mais conceituais, inteligentes e inovadores, não tão técnicos e de informação”. Entrevistas concedidas à autora, 2006-2007.
} 
de Comunicação e Artes (ICA) da UnB. O objetivo era que os alunos entrassem no universo cognitivo da arte, "descortinando-o"42. O IPC introduziu o postulado de que o conhecimento deveria ser construído com base no agrupamento de áreas gerais e que era conveniente formatar um curso básico de dois anos, em que os alunos pudessem fazer as primeiras experiências, contatos, observar e criar dentro da arte. Os três últimos anos seriam no campo estritamente profissional, resultando numa formação com ampla base de conhecimentos ${ }^{43}$. Para Paulo Bastos, na época, poucos professores procuravam ter uma visão abrangente, quase "todos éramos amadores", num sentido estrito, já que a grande maioria dos arquitetos professores, entre $80 \%$ e $90 \%$, não tinham realizado cursos de pedagogia ou comunicação. Dava-se aula por intuição, sem ter um pensamento organizado sob o ponto de vista pedagógico, situação não muito diferente da atual ${ }^{44}$. Das inúmeras reuniões e conversas realizadas para organizar esse novo curso, tinham ficado claras as idéias relativas às características e ao ritmo de trabalho que se pretendia: os alunos desenvolveriam suas próprias potencialidades; jamais se daria a solução de um problema, mesmo que não se concordasse com a proposta do aluno; o professor deveria ter, em certo sentido, o papel de 'advogado do diabo', não poderia esmagar 0 aluno com o peso de sua experiência. E era preciso ficar alerta quanto à desigualdade social, à injustiça, à falta de liberdade; lutar pela liberdade de crítica e não se dobrar frente a imposições dadas pelo contexto político, social, econômico e cultural ${ }^{45}$. Outros postulados, segundo Paulo Bastos, diziam respeito à busca de uma formação de caráter humanista, sobretudo no sentido de não dividir a realidade, já que ela é una e seus aspectos são relacionados. Isso implicava formular como objetivo de ensino o desenvolvimento da capacidade de relacionar e de despertar a permanente curiosidade nos

\footnotetext{
${ }^{42}$ Bastos, Paulo, 2006, entrevista concedida à autora.

${ }^{43}$ Ibid.

${ }^{44}$ Ibid.
} 
alunos e evitar vícios que significassem a negação dessa abrangência e consolidassem verdades que poderiam abrir caminhos para a nãointegração ${ }^{46}$.

Em síntese, para Paulo Bastos havia na formatação desse curso um grande esforço para integrar o conhecimento, que se originava no modelo do ICA da UnB, do qual era 'herdeiro', fechado pelo regime militar em 1964.

A FAU-SJ C enfrentou, durante toda sua existência, o embate entre uma estrutura pedagógica desconhecida e estranha para os moldes da mantenedora e as determinações de seu corpo financeiro e administrativo ${ }^{47}$. I sso contribuiu para configurar uma diferenciação entre dois poderes, um de direito e outro de fato: o poder de direito estava constituído pelo aparato administrativo e financeiro da entidade mantenedora, enquanto o poder de fato era exercido pela estruturação pedagógica do curso e seus órgãos decisórios. Esse embate acontecia, porém, só na faculdade de arquitetura, que ficava assim isolada dentro da estrutura de funcionamento geral da mantenedora ${ }^{48}$.

Desde o início a estrutura pedagógica da FAU-SJ C possibilitava, por seu caráter democrático, a participação do corpo discente, permitindo flexibilidade, autonomia, a auto-gestão de suas estruturas e a construção de uma disciplina interna própria ${ }^{49}$ - o que se revelava na elaboração e discussão dos temas desenvolvidos em cada semestre, tanto pelos professores quanto pelos estudantes, na efetiva e intensa participação nas aulas, na avaliação conjunta de estudantes e professores, nos trabalhos curriculares desenvolvidos sempre em equipe, com real participação de cada integrante. Muitas vezes, em função do andamento do curso, fazia-se uma reestruturação

\footnotetext{
${ }^{45}$ Bastos, Paulo, 2006, em entrevista concedida à autora.

${ }^{46}$ Ibid.

${ }^{47}$ Fernandes, Ari e outros, 1976 (b): 02. Anexo IV.

48 Ibid.

${ }^{49}$ Fernandes, Ari e outros, 1976 (b): 02. Anexo IV.
} 
metodológica ${ }^{50}$, o que foi motivo de debates, em muitos casos acirrados.

Ari Fernandes e outros, no texto 'Prática-Investigação', destacam as freqüentes discussões nos corredores, seminários interclasses e assembléias gerais e/ou permanentes dos estudantes. As atividades iniciavam-se democraticamente nas salas de aula e, de acordo com a complexidade dos problemas em deliberação, chegava-se à Plenária, culminando assim com a mobilização e a participação de estudantes e professores; em função da legislação vigente, as decisões eram então ratificadas pela Congregação ${ }^{51}$. Cabe também registrar a ativa participação dos estudantes no debate sobre o currículo escolar, regimento interno e órgãos de apoio, segundo todas as fontes consultadas.

Desde sua abertura, a FAU-SJ C, uma das escolas de arquitetura mais caras do Brasil, funcionava em período integral, exigindo a participação intensiva dos estudantes, que ficavam assim muitíssimo limitados para realizar trabalhos remunerados que ajudassem no seu sustento; estes dois fatores contribuíram para definir a origem de classe ou a composição social dos estudantes ${ }^{52}$.

No primeiro dia de aula os estudantes foram informados de que a proposta de ensino do IPC constituía-se num projeto experimental, com estrutura básica de trabalhos semestrais. No primeiro semestre, organizaram-se equipes com dez alunos cada uma com a proposta de desenvolver o tema 'A cidade de São J osé dos Campos'. O que implicava, segundo vários ex-estudantes dessa faculdade, entre eles Regina Cardarelli, na apropriação da cidade, já que a grande maioria dos alunos vinha de outros lugares, em especial de São Paulo. A linguagem proposta era audiovisual.

\footnotetext{
${ }^{50}$ Ibid.: 02-03. Anexo IV.

51 Ibid.

${ }^{52}$ Fernandes, Ari e outros, 1976 (b): 03. Anexo IV. Na visão desses autores, isto foi determinante no processo desenvolvido nos seis anos de existência da FAU-SJC.
} 
Essas equipes deveriam percorrer a cidade, registrando por meio de fotos, desenhos, filmes, entrevistas com moradores etc., o que considerassem mais significativo, para depois elaborar um audiovisual sobre 0 aspecto urbano escolhido. ${ }^{53}$ Foi realizado um curso rápido de fotografia, som e cinema, de caráter operacional, do qual participaram, entre outros professores, Dalton de Luca e J ean Claude Bernardet ${ }^{54}$. Esse curso, que se incluiu na Programação para a Abertura e Formação do Curso de Arquitetura, contou com conferências do cineasta Maurice Capovilla; dos arquitetos J oão W. Toscano, José Cláudio Gomes, Flavio Império; do engenheiro Ernest Roberto de Carvalho Monge; do sociólogo J uarez R. Brandão; do professor Andreas Pavel; do musicista e maestro tropicalista Damiano Cosella e dos poetas e lingüistas Haroldo de Campos e Décio Pignatari.

O resultado, na visão de Paulo Bastos, foi fantástico e surpreendente. “Para esse pessoal recém-saído do ginásio, foi uma enorme descoberta: uma nova maneira de perceber uma cidade, suas paisagens, entender 0 uso que seus moradores faziam dela, uma maneira diferente de olhar a arquitetura e urbanismo". Diversos arquitetos que estudaram nessa faculdade lembram que os alunos vinham de uma estrutura de ensino mais tradicional e essa foi uma experiência que arejou tanto as suas cabeças quanto as dos professores; para esses ex-alunos da FAU-SJ C também importante foi o fato de que, entre os estudantes, um grupo provinha dos movimentos das lutas dos excedentes e trazia uma visão diferente da vida, pois era mais politizado e mais maduro, consciente do momento político, do Al 5 etc ${ }^{55}$.

Os professores e também os estudantes da FAU-SJ C tiveram, desde 0 início, a preocupação de ampliar o debate, tanto de arquitetura e urbanismo quanto na inter-relação com outros campos do conhecimento, refletindo-se essa intenção também nas atividades

\footnotetext{
${ }^{53}$ Bastos, Paulo, 2006, em entrevista concedida à autora.

${ }^{54}$ Ibid.

${ }^{55}$ Cardarelli, Regina; Cury, Nabil; Dau, Renato. Em entrevistas concedidas à autora, 2006 e 2007.
} 
realizadas junto à comunidade. Assim, o debate interno na faculdade tomava a forma de uma intersecção entre as problemáticas no interior do curso de graduação e a análise da comunidade na qual se inseria ${ }^{56}$. No primeiro semestre os estudantes não tinham aulas teóricas. Cada equipe inscrevia-se para atendimento com os professores, que inseriam conteúdos específicos, discussões, ajudando a focar o trabalho. ${ }^{57}$ Nesses atendimentos, segundo Regina Cardarelli, os estudantes apresentavam esboços realizados em pequenos cadernos, indicando, por exemplo, qual aspecto significativo da cidade fora selecionado para a elaboração do audiovisual proposto. Eram questionados sobre o que se queria dizer com tal foto, qual a intenção, qual o tipo de linguagem mais conveniente, se supercontraste, se nevoada etc.

As equipes definiam a abordagem do trabalho após as discussões e atendimentos: algumas desenvolveram 0 audiovisual com base nos grandes monumentos da cidade, outras centraram o foco na arquitetura, enfatizando as edificações; outras optaram por discutir as questões sociais e outras ainda que preferiram abranger a cidade do ponto de vista da paisagem urbana ${ }^{58}$.

Ex-alunos entrevistados afirmaram que a metodologia de ensino obrigava a pensar. Tinham que descobrir o que precisavam para realizar o trabalho e construir o conhecimento procurando, por um lado, os professores adequados para a orientação, por um lado e, por outro, definindo a técnica de apresentação em audiovisual.

Os estudantes mergulharam nessa forma de adquirir conhecimentos como vivência experimentada integralmente: passavam horas fazendo trabalho de campo, madrugadas a fio elaborando, discutindo, trocando

\footnotetext{
${ }^{56}$ Fernandes, Ari e outros, 1976 (b): 01. Anexo III.

${ }^{57}$ Cardarelli, Regina, 2006, em entrevista concedida à autora. Para Guto Lacaz toda faculdade de arquitetura deveria ter disciplinas de cinema (em entrevista concedida à autora).

${ }^{58}$ Ibid.
} 
idéias e, ao fim do semestre, produziram dez audiovisuais de excelente qualidade que foram apresentados à comunidade ${ }^{59}$.

\section{1a crise: o curso seriado (2을 semestre de 1970)}

Em julho do mesmo ano, porém, o corpo docente inicial, sem condições mínimas para continuar com o trabalho, e sem receber remuneração havia vários meses, demitiu-se coletivamente; cedo se percebeu que à mantenedora não interessavam experiências didáticas pioneiras e que seu modelo de ensino era o curso seriado tradicional ${ }^{60}$.

Com base nesse modelo de curso, a instituição realizou novas contratações de professores para lecionar disciplinas estanques e isoladas. Eles permaneceram três meses, à revelia dos alunos, que se declararam em assembléia permanente ${ }^{61}$.

O segundo semestre transcorreu com uma metodologia totalmente diferente da inicial, uma surpresa para a maioria dos alunos; tinham aulas tradicionais, expositivas, porém poucas, porque como não havia lugar fixo dependiam da disponibilidade de salas emprestadas dos outros cursos, sem pranchetas e com laboratórios improvisados. Podese dizer que o semestre caracterizou-se pela conscientização da falta de lugar $^{62}$. Se a temática do primeiro semestre era compatível com a falta de salas adequadas, porque se desenvolvia com pesquisa de campo a maior parte do tempo, no segundo semestre essa falta de lugar inviabilizava o desenvolvimento das atividades ${ }^{63}$.

\footnotetext{
${ }^{59}$ Bastos, Paulo; Cardarelli, Regina, 2006, em entrevistas concedidas à autora.

${ }^{60}$ Fernandes, Ari e outros, 1976 (b): 13. Em carta de 03 de agosto de 1970 endereçada à Fundação Valeparaibana de Ensino, notifica-se que “resguardados no artigo 483, letra 'd' da Consolidação das Leis do Trabalho, somos obrigados a considerar rescindidos os contratos de trabalho mantidos com V.V.S.S., e, assim sendo, contra a nossa vontade, deixamos de assumir o emprego nesta data”. Assinam: professores Paulo de Mello Bastos, Ricardo I. Ohtake, Milton F. Pelliciota, José Augusto Berlinck, Dalton De Lucca, Plácido de Campos Jr, Ruth Amorin Toledo. Documento cedido à autora por Bastos, Paulo, 2006.

${ }^{61}$ Ibid.

${ }^{62}$ Cardarelli, Regina, 2006; Cury, Nabil, 2007; Daud, Renato, 2007; Lacaz, Guto, 2007. Em entrevistas concedidas à autora.

${ }^{63}$ Cardarelli, Regina, 2006; Cury, Nabil, 2007; Daud, Renato, 2007; Lacaz, Guto, 2007. Em entrevistas concedidas à autora.
} 
Parece que a fundação esperava que o curso de arquitetura fosse tão rentável quanto os outros existentes, e só no segundo semestre percebeu que o investimento era grande e decidiu minimizar seus custos implantando um curso seriado normal, afirma Regina Cardarelli.

\section{A resistência ao curso seriado: a luta pela volta do I PC}

Os alunos não aceitaram a mudança realizada pela mantenedora e pretendiam continuar com o corpo inicial de professores, retomando a proposta do IPC. Para isso decidiram levar suas reivindicações a instâncias superiores ${ }^{64}$.

As atividades de essência criativa que foram desenvolvidas no primeiro semestre contribuíram para gerar no conjunto dos estudantes disposição de lutar para conseguir o que consideravam o direito a um ensino pioneiro e de qualidade. Passaram o semestre procurando apoios variados, que incluíam o Quartel de Caçapava (6o Regimento de Infantaria), o Centro Tecnológico de Aeronáutica, do qual fazia parte 0 ITA, e a imprensa ${ }^{65}$.

Para entender esse processo é preciso lembrar que a participação conjunta de professores e estudantes - tanto no âmbito interno como no dos trabalhos realizados e vivenciados junto à comunidade - foi fundamental para a construção e manutenção do poder de fato citado anteriormente, que caracterizava a estrutura de poder interno da FAUSJ $\mathrm{C}^{66}$.

Desde 0 1ํㅗ semestre da escola o movimento estudantil criou o Diretório Acadêmico, organizou-se em assembléias permanentes, reivindicou a plena implantação da escola, o que resultou no crescimento dos

\footnotetext{
${ }^{64}$ Cardarelli, Regina, 2006, entrevista concedida à autora. Também Cury, Nabil,, 2007, em entrevista concedida à autora

65 Ibid.

${ }^{66}$ Fernandes, Ari e outros, 1976 (b): 06 Anexo IV. Também Cardarelli, Regina, 2006, em entrevista concedida à autora.
} 
estudantes ${ }^{67}$ e na percepção de que transitavam por caminhos contraditórios de uma realidade complexa.

Sua mobilização na busca de apoio para as mudanças pleiteadas contribuiu para a destituição da presidência da Fundação Valeparaibana de Ensino. Em contrapartida, as autoridades envolvidas no episódio ganharam legitimidade para exercer um controle velado sobre as atividades da faculdade. Parte desse controle foi a proibição de apresentar à comunidade os trabalhos desenvolvidos pelos estudantes a partir de agosto de 1972.

O movimento estudantil foi bem-sucedido ao garantir o reinício das aulas, mas não conseguiu viabilizar a infra-estrutura minimamente requerida para a normalização do curso e a instalação definitiva da FAU-SJ C. Essa forma de participação estudantil - presente em todo o processo de construção das diversas estruturas didáticas do curso (Instituto de Projeto e Comunicação, Ateliê Central, Ateliê integrado, Unidades Interdepartamentais) - contribuiu de maneira decisiva para congregar os estudantes de todos os semestres numa forma de representação democrática que se organizava tanto horizontal quanto verticalmente, junto aos órgãos decisórios da FAU-SJ C ${ }^{68}$.

\section{A volta do I PC}

Em 1971, com a recontratação do corpo docente inicial e a retomada da proposta do IPC, a FVE alugou um prédio fora da cidade para o funcionamento do curso de arquitetura: tratava-se de um antigo seminário desativado que incluía o mobiliário específico e que, com a boa vontade de alguns estudantes e 0 apoio de um funcionário com habilidades de marceneiro, se transformou em pranchetas. Essa atividade foi desenvolvida como uma experiência da disciplina Projeto do Objeto, que possibilitou o contato com as idéias de modulação, linha

\footnotetext{
${ }^{67}$ Ibid.
} 
de montagem, flexibilidade, resistência dos materiais, maneiras próprias de junção, trabalho em equipe etc.; ou seja, permitiu vivenciar questões relacionadas à industrialização de mobiliário, tão discutidas na época ${ }^{69}$. Para os alunos foi uma experiência de ensino-aprendizagem proveitosa, com filiação clara à escola Bauhaus, e para a entidade mantenedora representou uma economia significativa na compra do mobiliário inicial básico para o curso de arquitetura ${ }^{70}$.

Essa experiência também serviu de base para projetar e construir o mobiliário das repúblicas estudantis: com caibros de madeira, diversos projetos de sistemas de montagem foram realizados pelos próprios estudantes.

Em 1971, 3으 semestre letivo da primeira turma, o curso estava estabilizado: além de salas amplas com pranchetas, contava com piscinas e quadras de esportes e com os serviços de uma cozinheira contratada devido à distância em relação à cidade ${ }^{71}$.

Além da recuperação do semestre perdido, uma comissão foi nomeada com o objetivo de elaborar a justificativa e estruturação básica do IPC. Essa comissão, da qual participou o arquiteto e professor Paulo de Mello Bastos ${ }^{72}$, elaborou um documento - chamado de Documento Básico J ustificativo do IPC - detalhando o instituto, constituindo as bases para sua organização. Considero interessante registrar alguns trechos do mesmo para ajudar na compreensão do processo dessa faculdade:

\footnotetext{
${ }^{68}$ Fernandes, Ari e outros, 1976 (b): 06. Anexo IV. Também Cardarelli, Regina, 2006, em entrevista concedida à autora.

${ }^{69}$ Cardarelli, Regina, 2006; Cury, Nabil, 2007. Em entrevistas concedidas à autora.

${ }^{70}$ Ibid.

${ }^{71}$ Cardarelli, Regina, 2006; Cury, Nabil, 2007. Em entrevistas concedidas à autora.

72 Segundo carta de Paulo Mello Bastos, de 03/01/1972, endereçada ao novo diretor da FAUSJC, Aluísio Rosa Monteiro. Nela apresentava-se o resultado do trabalho dessa comissão: 1) documento básico justificativo contendo uma introdução e a justificativa dividida em 16 pontos; 2) curriculum pleno; 3) fluxograma e quadro geral da estrutura didática. Documentos pertencentes ao arquivo do professor Bastos, com data de dezembro de 1971, cedidos à autora em 2006. Ver também Fernandes, Ari e outros, 1976 (b): 14.
} 
"O Instituto de Projeto e Comunicação é a proposta de transformação da Faculdade de Arquitetura e Urbanismo de São José dos Campos"73, formulada "em função de existirem uma série de profissões, as que funcionam na área de criação ao nível do consumo de massa, que estruturalmente tem uma mesma metodologia de abordagem"174. Arquitetura, urbanismo, desenho industrial, imagem e som (cinema, televisão, comunicação visual e música) são atividades criadoras que podem ser vistas como projetos de produtos (design) ${ }^{75}$. Permeia essa declaração de princípios a revalorização da Bauhaus, que, como dito anteriormente, estava sendo resgatada desde os anos 1960, no mundo e na América Latina.

Nesse documento, considerou-se que São J osé dos Campos oferecia fatores que possibilitavam a implantação de uma estrutura didática pioneira:

- Situada no eixo Rio-São Paulo, a região do Vale do Paraíba mostrava-se na época como um real corredor de desenvolvimento, beneficiando-se da força econômica dessas duas metrópoles; e São J osé dos Campos catalisava aceleradamente a industrialização.

- Pela implantação de vários centros federais de pesquisa de alto nível, como o CTA e o CNAE, a cidade consolidou posição como maior pólo regional de desenvolvimento com projeção nacional.

- Havia necessidade urgente de resolver problemas decorrentes do planejamento e da comunicação, o que aumentava notavelmente a demanda de profissionais qualificados nessas áreas.

- As potencialidades da região criavam condições para a implantação de iniciativas pioneiras ${ }^{76}$.

Afirmava-se, nesse documento, que na maioria dos casos as universidades brasileiras constituíam conglomerados de escolas isoladas

\footnotetext{
${ }^{73}$ Bastos, Paulo e outros, 1971: 01 (Documento Básico Justitficativo do IPC).

${ }_{75}^{74}$ Ibid. Ver também Fernandes, Ari e outros, 1976 (b): 14.

${ }^{75}$ Ibid: 04.

${ }^{76}$ Bastos, Paulo e outros, 1971: 01, 04 e 05
} 
agrupadas fisicamente, mas sem vínculos, exceto o administrativo. A estrutura interna de cada uma dessas unidades, componentes da universidade era, quase sempre, formada por cátedras estanques e individualizadas. Ainda segundo o Documento Básico, "só recentemente, a Legislação Federal - através do decreto lei 53 e 252 veio determinar e impulsionar o processo da reforma universitária, elegendo como unidade mínima de decisão o departamento e estabelecendo um elenco de medidas que, desenvolvidas e corretamente aplicadas, levarão de maneira segura as universidades brasileiras à integração e interação de suas partes e componentes, à flexibilidade interna necessária ao atendimento da constante evolução das várias áreas do conhecimento humano, à centralização de funções e equipamentos, fundamental para a economia de tempo e recursos em qualquer atividades universitária"77.

No documento defendia-se a tese da estruturação da universidade partindo de unidades centrais, abrangendo cada uma delas uma determinada área do conhecimento: ciências puras, humanas, artes, tecnológicas etc.; essas unidades deveriam ministrar ensino e pesquisa em duas fases consecutivas:

- básica, de forma geral para toda a universidade;

- profissional, de maneira específica e particular $^{78}$.

Os estudantes só optariam por um curso profissional após vivenciar uma experiência básica de pesquisa, que contribuiria para esclarecer e definir suas habilidades e interesses. A formação do futuro profissional aprofundava-se e consolidava-se com a criação, desde o início, de uma visão global da realidade, pensada como a razão de ser da universidade ${ }^{79}$.

\footnotetext{
${ }^{77}$ Ibid: 02. Cabe aqui diferenciar essa organização em departamentos, antecipada no ICA da UnB, implicando agrupamento de vários cursos ou faculdades pertencentes a um departamento, diferente dos departamentos estabelecidos na FAU-USP, por exemplo, que agrupam várias disciplinas pertencentes a uma mesma faculdade. Grifos nossos.

${ }^{78}$ Ibid.: 02 e 03.

79 Ibid.
} 
Frente ao quadro apresentado na Fundação Valeparaibana de Ensino, onde deveria ser implantada uma nova faculdade de arquitetura, existia um grupo de cinco faculdades (Ciências Econômicas e Administrativas, Ciências e Letras, Direito, Engenharia, Filosofia e Serviço Social) em funcionamento, porém num regime de isolamento de umas em relação às outras com a conseqüente desarticulação do conjunto, sem a existência de uma universidade. Nesse contexto, a criação de uma faculdade de arquitetura tradicional produziria mais uma escola igualmente isolada e desvinculada do todo ${ }^{80}$.

Ainda na visão dos autores do Documento Básico, grande número de faculdades de arquitetura teve que acrescentar aos seus currículos disciplinas visando - além do aprofundamento dos conhecimentos necessários à formação do arquiteto - a ampliação e a diversificação dessa área profissional; isso porque essas escolas, por serem isoladas, eram obrigadas a criar dentro de si propostas que fizessem frente às constantes e rápidas modificações da realidade, por faltar-lhes o apoio de uma universidade estruturada para permitir encontrar respostas comuns a várias áreas da própria universidade. Isso resultava em aumento de equipamentos, aparelhos administrativos e carga didática ${ }^{81}$.

Fazia parte das idéias apresentadas nesse documento a permanente preocupação com uma universidade que não fosse fechada em si, nem isolada da comunidade a que pertencesse, procurando então canais universitários de atuação na comunidade: seja sob a forma de transmissão de conhecimentos por meios de expressões artísticas e culturais, propondo para isso a criação de minicentros, seja sob a forma de prestação de serviços através de convênios com entidades oficiais industriais e de classe, a criação de um Centro de Planejamento (Ceplan) e, por fim, a publicação dos trabalhos e atividades ${ }^{82}$.

\footnotetext{
${ }^{80}$ Ibid.: 03.

${ }^{81}$ Ibid.: 03 e 04. Percebe-se aqui a filiação desse documento à proposta da UnB, vista nos capítulos anteriores.

${ }^{82}$ Ibid.: 01 e 03.
} 


\section{A estruturação do I PC}

A proposta de estruturação do Instituto de Projetos e Comunicação fundamentou-se nos princípios citados acima.

Argumentava-se que, sob o prisma da metodologia de abordagem e da criatividade, os profissionais egressos do IPC nas suas diferentes áreas possuíam semelhanças estruturais de formação. Atribuía-se grande importância à interação dos diferentes setores profissionais ${ }^{83}$.

\section{Estrutura departamental}

O modelo proposto aspirava à perspectiva de criação da Universidade do Vale do Paraíba, que se iniciaria com o IPC, comportando três departamentos ${ }^{84}$ :

- DPC - Departamento de Projeto e Comunicação, responsável pela informação básica e formação profissional nas áreas de Imagem e Som, nas quais se incluíam cinema, televisão e música.

- DPPU - Departamento de Projeto do Produto da Edificação e da Urbanização, responsável pela informação básica e formação profissional nas áreas de projeto de arquitetura, planejamento e artes gráficas; o projeto do objeto estava implícito, já que no texto 'Prática-Investigação' era empregado em substituição a artes gráficas.

- DCHTF - Departamento de Ciências Históricas e Tecnologia do Produto, responsável pelas disciplinas na formação básica e profissional de tecnologia, história e metodologia de trabalho e que não formaria nenhum tipo de profissional específico.

\footnotetext{
${ }^{83}$ Ibid.: 05. Esta opinião é compartilhada por Lacaz, Guto, 2007, em entrevista concedida à autora.

${ }^{84}$ Ibid.: 05. Também Fernandes, Ari e outros, 1976 (b): 14.
} 
Esse modelo correspondia, num primeiro momento, a uma faculdade de arquitetura e urbanismo com o acréscimo de dois órgãos de pesquisa, os Minicentros de Som e de I magem, pensados como os canais de relacionamento inicial entre a comunidade e a universidade ${ }^{85}$.

\section{Organização do curso}

Definiu-se a duração do curso em cinco anos, organizados em três etapas ${ }^{86}$ :

1. Curso Básico, chamado de Ateliê Básico Integrado.

2. Curso de Profissionalização, onde se desenvolveria a formação específica.

3. Tese de Diplomação, finalizando a Graduação.

A primeira etapa, com duração de quatro semestres, seria comum a todos os alunos em todas as áreas. Estavam previstas matérias profissionalizantes para possibilitar aos alunos a opção por uma das áreas: Imagem e Som (que incluía cinema, televisão e música) e Arquitetura e Urbanismo; na segunda etapa, o curso profissionalizante com predomínio de matérias específicas das áreas, imagem, objeto e som, também previsto para quatro semestres, implicava, ao seu término, na definição dos estudantes por uma das áreas de interesse ${ }^{87}$. Por fim, a Tese de Graduação ou Diplomação teria duração de dois semestres, tempo no qual o aluno deveria desenvolver um projeto na área escolhida no Curso de Profissionalização ${ }^{88}$.

Em relação aos docentes, o documento propunha para o IPC uma equipe básica em tempo integral, que deveria se integrar com as outras faculdades da Universidade por meio de conferências, cursos comuns, seminários, formação de equipes mistas de trabalho e assessorias ${ }^{89}$.

\footnotetext{
${ }^{85}$ Fernandes, Ari e outros, 1976 (b): 14.

${ }^{86}$ Bastos, Paulo e outros, 1971: 01 e 05.

${ }^{87}$ Ibid.: 01 e 05.

${ }^{88}$ Ibid.: 05

${ }^{89}$ Ibid.: 01 e 05.
} 
Porém, segundo Cardarelli, a idéia de que o IPC teria dois anos básicos e que depois se dividiria em três cursos (arquitetura, cinema-fotografia e música) foi-se perdendo; era previsível que só se desenvolveria o curso de arquitetura, já que não havia corpo de professores nem estrutura para mais ${ }^{90}$.

No primeiro semestre de 1971 , os temas propostos relacionavam-se aos municípios vizinhos. As aulas eram mais dirigidas que no primeiro semestre do ano anterior; o terceiro semestre letivo foi mais calmo, mas a sensação era que os estudantes estavam isolados num gueto, longe da cidade ${ }^{91}$.

\section{A relação com a comunidade}

Durante os seis anos de vida dessa faculdade, merece destaque a relação estabelecida com a comunidade, por ser uma característica que a diferenciava de outras, e só compreensível no contexto desse momento e lugar.

Primeiramente, essa relação estava condicionada pela localização da escola na cidade de São J osé dos Campos, considerada a cidade mais progressista do Vale do Paraíba; sendo a maioria dos estudantes e dos docentes predominantemente de São Paulo, sua permanência gerava um intenso vínculo de participação com a comunidade ${ }^{92}$.

Como em outras cidades onde as faculdades recebem alunos de diversas regiões, também em São J osé dos Campos os estudantes se organizaram em repúblicas, o que, pela força da convivência, contribuiu para formar um dos pontos de apoio mais importantes para as ações desenvolvidas na cidade, fato reforçado pela realização de trabalhos

\footnotetext{
${ }^{90}$ Cardarelli, Regina, 2006, em entrevista concedida à autora.

91 Ibid. Também Cury, Nabil, 2007, em entrevista à autora.

${ }^{92}$ Fernandes, Ari e outros, 1976 (b): 03. Anexo IV. Afirmação também confirmada por Cardarelli, R. e Bastos, Paulo, em entrevistas concedidas à autora, 2006.
} 
conjuntos com os docentes, que possibilitaram fortalecer esse vínculo com a comunidade ${ }^{93}$.

Outra atividade que contribuiu fortemente para a união do grupo de arquitetura e para criar sua identidade foi a realização de rodas de samba às sextas-feiras, das quais participavam conjuntamente estudantes, funcionários e professores ${ }^{94}$.

Regina Cardarelli lembra que essa relação com a comunidade tinha também dificuldades; na época, São J osé dos Campos era uma cidade pequena, de cerca de 50 mil habitantes, que tinham desconfiança em relação a esses estudantes de fora, temporários, que iriam embora. Essa desconfiança já manifestada em relação aos alunos do ITA agravou-se com a turma de arquitetura. Marcadamente diferenciados, os alunos com seus cabelos e roupas exóticas, alguns hippies, que fotografavam pela cidade, chocavam a população, que não via com bons olhos a possibilidade de amizades com seus filhos; os estudantes de arquitetura ficavam, assim, quase isolados na cidade ${ }^{95}$.

Por outro lado, superando as limitações apontadas acima, a integração estudantil transcendeu o âmbito interno da FAU-SJ C, estendendo-se à comunidade da cidade. Essa inter-relação desenvolveu-se tanto nos trabalhos de curso e pesquisa quanto nas atividades realizadas com estudantes de outras escolas ${ }^{96}$.

A filosofia geral da FAU-SJC incluía a tentativa de uma correta avaliação da realidade sobre a qual atuava e, nesse sentido, os trabalhos desenvolvidos no curso eram apresentados à comunidade. Além disso a faculdade contava com órgãos de prestação de serviços externos, como o Centro de Imagem e Som (CEIS), o Centro de Estudos e Debates (CED) e o Centro de Planejamento da FAU-SJ C (Ceplan), além de

\footnotetext{
${ }^{93}$ Fernandes, Ari, 1976 (b): 03. Anexo IV. Também Cardarelli, Regina, 2006, em entrevista à autora.

${ }_{94}$ Cardarelli, Regina, 2006, em entrevista à autora.

95 Ibid. Também Bastos, Paulo, que afirmou que a Aeronáutica "ficava de olho” frente aos "barbudos” de arquitetura, vistos como subversivos, coincidindo com esta afirmação, Fernandes,Ari e Cury, Nabil, 2007, em entrevistas à autora.
} 
órgãos de apoio à estrutura didática ${ }^{97}$, entre os quais destacava-se 0 convênio realizado entre Ceplan e Prefeitura Municipal, em 1973, para a elaboração do Cadastro de Área do Município para Renovação Urbana Fundo do Vale. No mesmo ano estabeleceu-se um convênio entre o CEIS e o Museu da Imagem e do Som de São Paulo (MIS) para a realização do Registro da Interferência Sócio-cultural da Rio-Santos no Litoral Norte. Outro convênio com esse Museu, em 1975, permitiu produzir a exposição 'São Paulo Antigo'. Nesse mesmo ano foi implantada uma praça em São J osé dos Campos, projetada por estudantes da FAU-SJ C premiados no concurso promovido pela Urban e pela Prefeitura de São J osé dos Campos; também realizou-se uma Exposição de Cartazes do Cinema Brasileiro, organizada por estudantes. Apresentou-se no Congresso da UIA, em Madri, Espanha, um trabalho de alunos da FAU-SJC escolhido para representar as faculdades de arquitetura brasileiras, com o tema Habitação de Emergência ${ }^{98}$.

Já o trabalho desenvolvido pelos estudantes da FAU-SJ C junto às dez faculdades da cidade inseria-se no contexto letárgico geral que permeava todo o país. Assim, todo apoio aos movimentos internos nesses cursos ficou limitado a uma divulgação isolada em cada escola; só a partir de 1973 os diretórios acadêmicos de forma conjunta promoveram eventos culturais e esportivos considerados imprescindíveis à vida cultural da cidade ${ }^{99}$.

Essas atuações, limitadas pela deficiência de infra-estrutura, por variadas formas de boicotes e também pelo cerceamento geral à liberdade de expressão, foram finalmente interrompidas com o agravamento da crise permanente na FAU-SJ C e, sobretudo, com a

\footnotetext{
${ }^{96}$ Fernandes, Ari e outros, 1976 (b): 04. Anexo IV.

${ }^{97}$ Ibid.

${ }^{98}$ Dados registrados por Fernandes, Ari e outros, 1976: 02 - 03. Anexo III.

${ }^{99}$ Fernandes, Ari e outros, 1976: 05. Anexo III.
} 
intensificação da repressão a toda e qualquer forma de organização estudantil $^{100}$.

\section{O debate sobre a formação do arquiteto na FAU-SJ C}

Outro aspecto importante diz respeito à participação dos estudantes da FAU-SJ C no movimento estudantil, que se iniciou com a organização e realização e do 1 ํㅡㄹ Encontro Nacional de Estudantes de Arquitetura (ENEA), realizado durante a XI Bienal em São Paulo, seção de Arquitetura, de setembro a dezembro de 1971. A reflexão e o debate pertinentes à formação do arquiteto foram objeto de trabalho conjunto dos estudantes de diversos cursos de arquitetura ${ }^{101}$, participando na Comissão de Redação da publicação 'Escolas de Arquitetura na XI Bienal' os estudantes da FAU-SJ C Márcio Freire Penteado, Plínio Walder Prado J r. E Sérgio Luiz Bianco.

A segunda turma de estudantes havia ingressado na faculdade no 20 semestre de 1971, quando a primeira atingia o 4으 semestre letivo, último do $1^{\circ}$ ciclo. A programação letiva das duas turmas realizou-se com base em um tema único, A Universidade Brasileira ${ }^{\mathbf{1 0 2}}$, tratado por todos os Departamentos em suas disciplinas. Esse tema, proposto pelo Departamento de Projeto, previa como produto final o anteprojeto da Universidade do Vale do Paraíba.

O desenvolvimento dessa proposta - vista na época como possível e cuja concretização estava mobilizando esforços - possibilitou vislumbrar a ampliação da integração disciplinar em torno de um tema de projeto, o que permitiria realizar uma transição ao 50 semestre letivo, no ano seguinte, início do 2 o ciclo do curso da turma inicial ${ }^{103}$.

O tema escolhido possibilitou, também, uma abertura importante para o debate, somada à ativa participação dos estudantes no concurso de

\footnotetext{
${ }^{100}$ Ibid. Também Bastos, Paulo, 2006, em entrevista concedida à autora.

${ }^{101}$ Fernandes, Ari, e outros, 1976 (b): 04 - 05. Anexo IV.

${ }^{102}$ Fernandes, Ari e outros, 1976 (b): 15.
} 
escolas de arquitetura da XI Bienal em São Paulo. A discussão estudantil sobre os aspectos políticos da reforma universitária, $\mathbf{0}$ significado da universidade brasileira, seu sentido histórico, os modelos de ensino existentes etc ${ }^{104}$. foi aprofundada e diversificada, colaborando para a reflexão crítica do próprio processo vivenciado, no seu contexto político e histórico ${ }^{105}$. Assim, segundo os autores do texto 'Prática-Investigação', inicia-se um período de posicionamento crítico, tanto de estudantes como de professores, que marcaria o desenvolvimento das atividades da FAU-SJ C nos semestres seguintes.

\section{Redução da proposta inicial do I PC}

No ano de 1972 ingressa uma nova turma, mediante a realização do terceiro vestibular e, com o aumento do número de alunos, novos professores foram contratados. Muitos deles vinham da FAU-Santos (da qual se falará brevemente no próximo capítulo), entre os quais Mayumi W. Souza Lima, Sergio Souza Lima, Ari Fernandes, Rodrigo Lefèvre (também professor da FAU-USP) e Francisco de Oliveira. Outros provinham da UnB como, por exemplo, J ean Claude Bernardet ${ }^{106}$. Havia então três turmas cursando simultaneamente a FAU-SJ C: a primeira no 50 semestre letivo, no 20 ciclo do IPC, desenvolvendo o tema Universidade Brasileira. A segunda cursava o 20 semestre letivo e a terceira o 10 semestre. Na turma do 50 semestre cada equipe devia desenvolver e detalhar um dos prédios do anteprojeto da cidade universitária proposto para abrigar a Universidade do Vale do

\footnotetext{
103 Ibid: $14-15$.

${ }^{104}$ Ibid.

105 Ibid.

${ }^{106}$ Bastos, Paulo, 2006, em entrevista à autora. Também o arquiteto Luiz Ackel, então estudante na FAU-Santos, 2006, em entrevista à autora.
} 
Paraíba ${ }^{107}$. O modelo adotado para o ciclo profissional do curso na área de formação do arquiteto era o do Ateliê Integrado ${ }^{108}$.

Na negociação com a mantenedora, para instalação do curso de arquitetura ficou estabelecido, devido à ausência absoluta de recursos financeiros, que o Departamento de Som e Imagem não participaria do ciclo profissional, restando como única opção a formação em arquitetura, o que foi mal recebido pela maioria dos estudantes ${ }^{109}$. Essa insatisfação incentivou a formação de Grupos de Trabalho (GT) que, objetivando a reorganização da escola, estudaram formas de superar 0 impasse criado. Aceitando a impossibilidade de concretizar o $2^{\circ}$ ciclo de Imagem e Som, os GT procuraram levar ao ciclo algumas disciplinas e também atividades de pesquisa relacionadas a essa área ao curso de arquitetura, já que havia, na época, o consenso de que para a formação do arquiteto era extremamente interessante o contato com essas áreas próximas a seu campo de conhecimento $^{110}$.

\section{Efetivação do Ateliê I ntegrado}

O trabalho desenvolvido pelos Grupos de Trabalho contribuiu com subsídios para a elaboração de uma programação conjunta do semestre. Em que pese a existência de opiniões diferentes e até opostas, efetivou-se o funcionamento de um Ateliê Integrado com a participação dos professores de Projeto, de História e de Tecnologia (que nesse momento já constituía um departamento separado) ${ }^{111}$. Programou-se que a participação de todos os professores seria

\footnotetext{
${ }^{107}$ Cardarelli, Regina, 2006; Araújo, Renato, 2007, em entrevistas à autora. Também Fernandes, Ari e outros, 1976 (b): 15.

${ }^{108}$ Fernandes, Ari e outros, 1976 (b): 15.

${ }^{109}$ Ibid.

${ }^{110}$ Fernandes, Ari e outros, 1976 (b): 15. Guto Lacaz comentou, a respeito, que nessa época prevalecia a idéia de que o projeto não era exclusivo do edifício: poder visualizar por etapas, se possível com desenhos, antever, era pertinente tanto para arquitetura quanto para música, cinema, fotografia. Nesse sentido ele se considera um arquiteto, um construtor de espaços, mesmo que no bidimensional, sempre usando em suas atividades os conhecimentos provenientes da arquitetura. 2007, em entrevista à autora.
} 
simultânea no horário do Ateliê, e para todos os semestre letivos foi desenvolvido um tema único: Sistema de Abastecimento de Gêneros Alimentícios em São J osé dos Campos ${ }^{112}$.

Essa experiência de construção da interdisciplinaridade deu forma às concretas dificuldades que deveriam ser aprofundadas no campo da teoria e que nesse momento estavam sendo discutidas também em outras faculdades de arquitetura da América Latina e do mundo, como por exemplo, na FAU da Universidade Nacional de Córdoba na Argentina.

No Ateliê, a falta de uma linguagem comum entre arquitetos, sociólogos, engenheiros, economistas e historiadores tornava o contato semanal confuso e agravado pelas divergências decorrentes das diversas possibilidades de abordagem do tema ${ }^{113}$.

Esses problemas são, na minha visão, centrais na construção de um trabalho interdisciplinar visto como processo e requerem tempo de elaboração devido à sua complexidade. A situação de precariedade contribuía como impedimento para que essa experiência fosse aprofundada, já que a "própria escola era um projeto de uma nova forma de ensino"114. Somava-se a isso o fato de que se carecia de infraestrutura operativa e os dados de apoio eram insuficientes, como também as condições para levantamentos de campo e a realização de pesquisas ${ }^{115}$.

Segundo Lacaz, enquanto os alunos desenhavam os projetos, uma parte dos professores, sociólogos e economistas, por exemplo, ficava ociosa no ateliê. Isso porque as etapas não estavam suficientemente articuladas e, talvez, por falta de uma programação que possibilitasse a entrada dos conhecimentos de cada disciplina nos momentos

\footnotetext{
${ }^{111}$ Ibid.

${ }^{112}$ Ibid. Também Lacaz, Guto; Araújo, Renato; Cardarelli, Regina; Cury, Nabil, 2007 em entrevistas à autora.

${ }^{113}$ Fernandes, Ari e outros, 1976 (b): 16.

${ }^{114}$ Lacaz, Guto, 2007, em entrevista à autora.

${ }^{115}$ Fernandes, Ari e outros, 1976 (b): 16.
} 
pertinentes - questões que poderiam ter sido superadas se houvesse 0 apoio efetivo da instituição mantenedora.

A própria proposta de Ateliê não consegue ser 'integrada', apesar de seu nome, porque prevalece nele a direção do Departamento de Projeto, atribuindo aos outros departamentos a tarefa de responder às perguntas que emergiriam do processo de projeto. 0 conflito estava colocado: jogo de vaidades, quem manda, quem é mais importante. Repetia-se, talvez com mais força, o embate vivido na FAUUSP, visto em capítulos anteriores.

Em finais de 1972, o Departamento de Projeto propôs que a estrutura do ciclo básico fosse dividida em Ateliê e Instrumental.

No Ateliê agrupavam-se cinco disciplinas em três áreas. No Instrumental, também cinco disciplinas que serviriam de preparo para o Ateliê do semestre seguinte, sem vínculo direto com o atual.

Para o ciclo profissional, a proposta do Departamento de Projeto era similar, especificando-se que a finalidade do Ateliê era a "elaboração de projetos com a participação de equipe interdisciplinar de orientadores".

Ficava claro o 'convite' do departamento nessa proposta, ao especificar em que fase tornava-se desnecessária a participação direta ou contínua de cada departamento. Dividindo o processo em três fases, ficava estabelecida para o Departamento de Tecnologia, a participação no início e no final; para o Departamento de História, explicitava-se que sua participação seria mais intensa na fase inicial, "orientando na conceituação do projeto, devendo atuar na área de estudos socioeconômicos e histórico-críticos". Na segunda fase não teria participação direta, podendo ser solicitada se necessário. E na última fase atuaria novamente com intensidade, para um "balanço crítico, relacionando a conceituação inicial ao anteprojeto final"116.

\footnotetext{
${ }^{116}$ Documento elaborado pelo Departamento de Projeto da FAU-SJC em 11/12/1972. Arquivo do arquiteto Paulo Bastos, cedido à autora.
} 
A proposta fazia também a distribuição de cargas horárias para os departamentos de Tecnologia e História, considerando que as horas não investidas no ateliê durante a fase do exercício de projeto poderiam ser utilizadas em outras atividades, tais como a preparação do ateliê do semestre seguinte, a coleta de dados ou 0 desenvolvimento das pesquisas.

Deve-se levar em consideração que, tratando-se de uma faculdade privada, onde os honorários dependiam das horas de aula ministradas, sem previsão de atividades de pesquisa ou extensão, essa distribuição era um fator limitativo dos vencimentos, o que levou, entre outras coisas, os professores das disciplinas não diretamente implicadas com o projeto a reivindicar maior carga horária para desenvolver os conteúdos que consideravam importantes, o que aprofundou os conflitos ${ }^{117}$. Outro aspecto conflitivo com os direitos trabalhistas referia-se à proposta de contratação de novos professores. Tal proposta previa contratos por semestre ou, no máximo, por um ano, e no final do período seria feita a avaliação fundamentada em critérios didáticos, freqüência e participação na organização da estrutura do curso. Esta posição que, obviamente, favorecia a empresa mantenedora e não levava em consideração os direitos trabalhistas dos professores era comum a outras experiências, como as da FAU-UnB e a do Taller Total em Córdoba, Argentina. A questão do professor-trabalhador, no entanto, merece uma discussão mais aprofundada, o que foge ao escopo desta tese.

Outra questão comum nesse período era a de que o professor deveria ter "experiência profissional em sua área específica de atuação". I sso significava que o perfil ideal do professor seria o de um profissional que dedicasse uma parte de seu tempo à docência e outra ao exercício da prática profissional.

${ }^{117}$ Fernandes, Ari, 2006, em entrevista concedida à autora. 
Diversos documentos ${ }^{118}$ produzidos entre o final de 1972 e final de 1973 revelam um grande esforço, tanto por parte dos alunos quanto dos professores, em fazer uma avaliação crítica do processo, visando uma proposta capaz de superar os impasses.

Algumas reuniões, realizadas em janeiro e fevereiro de 1973 no IAB, ${ }^{119}$ revelam, através do registro em atas, o envolvimento dessa instituição na criação das novas escolas de arquitetura ${ }^{120}$.

Nas reuniões de janeiro, entre as resoluções, destacam-se:

- "Fica reafirmado o Ateliê como forma de ensino, devendo ser adotado no primeiro semestre de 1973 (março a junho)".

- "As três áreas, imagem, som e arquitetura (espaço), não são uma seqüência na formação do aluno, mas são independentes, apesar da semelhança do ponto de vista de método de projeto de produção e consumo".

- "O objetivo do atelier é o de conseguir manipular todos os dados em várias áreas e transformá-los num projeto de espaço físico".

Na reunião de 08/02/1973 no IAB, também registrada em ata, a presença de mais alunos pareceu dar uma tônica mais 'organizativa'. Entre outras resoluções dessa reunião, podemos destacar:

- "Os professores designados para trabalhar junto aos alunos no ateliê de cada semestre devem organizar-se de forma que cada professor participe de maneira sistemática do trabalho de uma equipe em particular [...] porém todas as equipes de cada semestre terão uma programação comum de etapas [...]".

\footnotetext{
${ }^{118}$ Entre outros, a proposta elaborada pelo Departamento de Projeto em 11/12/1972, estabelecendo os critérios de aprovação; explicita-se nela que foi elaborada após consultas aos professores responsáveis por cada disciplina e semestre, tanto no ciclo básico quanto no profissional, do ateliê e dos instrumentais. Essa proposta é reafirmada na íntegra, em 19/01/1973, assinada pelo professor Maffei e pelo aluno Penna, representante do $6^{\circ}$ semestre. ${ }^{119}$ Reunião Plenária dos Professores, em 08/02/1973, no IAB. Ata da reunião de Projeto da FAU-SJC, em 17/01/1973, no IAB, São Paulo - segunda reunião de estruturação do curso para o $1^{\circ}$ semestre de 1973.

${ }^{120}$ Fernandes, Ari, 2006, em entrevista à autora. Pereira, Miguel, 2006, em entrevista à autora.
} 
- "A escolha dos temas do ateliê deverá ser feita em reunião de todos os professores do semestre", levando em conta "o equipamento previamente fornecido aos alunos, bem como os objetivos de cada área e departamento atuante naquele semestre [...] porém os conteúdos dos cursos de formação e instrumentais permanentes não precisam necessariamente rebater-se no ateliê".

\section{O início das críticas ao Ateliê}

As críticas ao IPC e ao ateliê como sistema onde predominava o Departamento de Projeto começaram a delinear-se no Texto básico para discussão no Fórum de Debates (alunos, professores, diretor) a realizar-se no dia 14/06/73', encaminhado pela representação do Departamento de Tecnologia ${ }^{121}$ à Comissão de Estruturação da FAU-SJ C e cuja análise será desenvolvida no próximo capítulo.

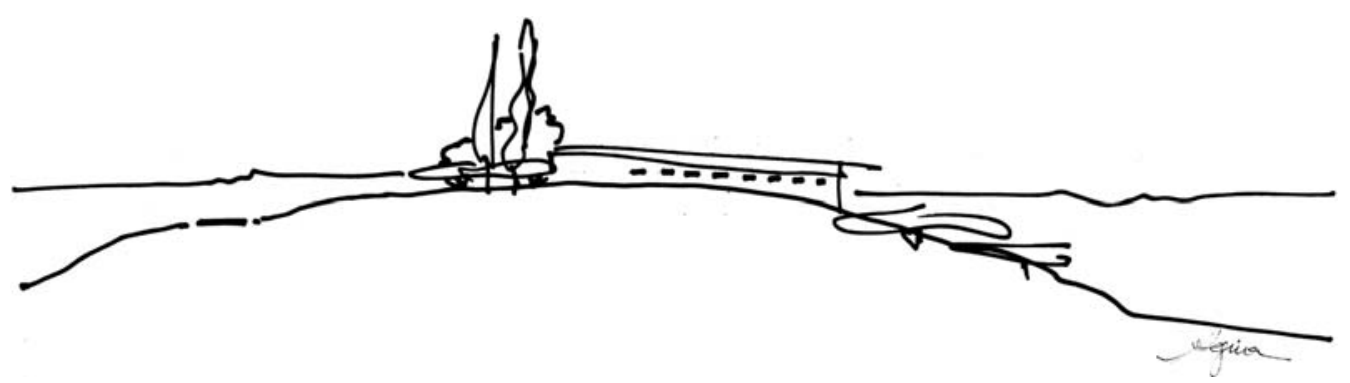

Vista do antigo seminário em que funcionou o IPC FAU-SJ C.

Desenho de Regina Cardarelli, 2008. Arquivo pessoal.

\footnotetext{
${ }^{121}$ Pertenciam ao Departamento de Tecnologia, na época, entre outros, Mayumi W. Souza Lima, Rodrigo Lefèvre e Sergio Souza Lima.
} 
Capítulo IV

DAS CRITICAS AO ATELIÊ ÀS UNIDADES

INTERDEPARTAMENTAIS DE ENSINO E PESQUISA NA FAU-SJC

\section{Considerações iniciais}

O Ateliê Interdepartamental pretendia a integração de todas as disciplinas do curso de arquitetura e urbanismo em torno do ateliê, visto como eixo central da faculdade. Esse modelo foi também denominado Ateliê Integrado e já fazia parte do ateliê do início dos anos $1960^{1}$ (exemplo disso foi o ateliê proposto pela reforma de 1962 na FAU-USP).

A redução dessa proposta ao nível possível resultou no Ateliê Central. 0 "Ateliê Integrado representa a consolidação final e completa da proposta original, só consegue ser implantado a partir dos debates em torno da reforma universitária, a partir de $1968^{\prime 2}$. Os cursos de arquitetura - vinculados a universidades devido às normas dessa reforma - corriam o risco de desmembrar-se em três institutos: Ciências Humanas, Artes e Comunicação e Ciências Exatas.

Frente a esse risco e também devido à diminuição da tensão entre arquitetura e engenharia foi possível, na FAU-USP, propor o Ateliê Integrado, visto como espinha dorsal do curso. Nesse modelo, as disciplinas técnicas e históricas compunham 0 ateliê subordinadas à temática e à programação do Departamento de Projeto $^{3}$, o que não contribuía para a integração e harmonia do conjunto do curso,

\footnotetext{
${ }^{1}$ Fernandes, Ari e outros, 1976: 127.

2 Ibid.: 128. Grifo nosso.
} 
colocando, na minha visão, obstáculos à real possibilidade de interdisciplinaridade no ateliê.

Na proposta do Ateliê Integrado, a atividade projeto era considerada o produto final do curso, seu meio e seu fim, e os temas a serem desenvolvidos no ateliê escolhiam-se a partir do repertório de atividades exercidas na profissão liberal do arquiteto, ou seja, na prática profissional dos professores-arquitetos, mas foram esses temas que permitiram a integração vertical e horizontal objetivada4.

A crítica aos Ateliês Central e Integrado pode ser sintetizada em três aspectos:

- "A impossibilidade prática de esses modelos desenvolverem pesquisas incorporadas ao ensino, com igual participação das áreas técnicas, humanas e de projeto.

- A redução das atividades escolares ao simples desenvolvimento de temas 'profissionais', que impõem um produto final predeterminado, limitando estudantes e professores ao trabalho de prancheta, enquanto única solução, empobrecendo o sentido do Projeto, que se torna mera 'reprodução de soluções clássicas análogas'.

- O academismo da postura pedagógica professor-aluno, prolongamento histórico do precedente 'mestre-aprendiz', que acaba perpetuando as práticas de trabalhos vigentes (dos professores) como modelos de soluções inquestionáveis (pelos alunos)" ${ }^{\prime 5}$.

Porém, é importante considerar que o Ateliê Central, posto em prática parcialmente a partir da década de 1960, refletia também a pressão exercida pelos arquitetos que desejavam adquirir maior força nas decisões no âmbito do ensino, já que a maioria dos cursos de

\footnotetext{
${ }^{3}$ Ibid: 128. Ver Também Albuquerque, Roberto Portugal, 2004 e Millan, Carlos, 1962.

${ }^{4}$ Fernandes, Ari e outros, 1976: 128. Ver também Millan, Carlos, 1962. Essa questão é também discutida por Elkin, Benjamin, 2000; Fontán, J. C. e Novillo Corvalán, Marcelo, 1971. ${ }^{5}$ Ibid: 128. De maneira similar, foi realizada crítica ao Taller de Composición Arquitectónica, ver Fontán, J. C. e Novillo Corvalán, Marcelo, 1971.
} 
arquitetura era dirigido por engenheiros, que ministravam as disciplinas técnicas contando com maior carga horária ${ }^{6}$.

Os arquitetos eram minoria nas votações nos órgãos colegiados, por exemplo, nas congregações, o que contribuía para que, nas escolas de arquitetura, os engenheiros exercessem domínio político. Frente a essa situação, na época, a palavra de ordem foi 'Arquitetura não é engenharia'"

A proposta do Ateliê Central ou do Ateliê Integrado modificava essa relação de poder, como também o método de ensino, revelando-se, na época, uma proposta muito progressista, motivo pelo qual o curso de arquitetura na UnB, cujo primeiro ciclo inseria-se no ICA, adotou esse modelo para o segundo ciclo ${ }^{8}$.

Em diversas faculdades de arquitetura latino-americanas, entre elas, no Brasil, a FAU-USP e a FAU-UFRG, a liderança dos cursos foi assumida pelos arquitetos, por meio dos ateliês; no contexto da prática profissional correspondente a essa época, foi possível introduzir no interior das escolas de arquitetura as linguagens, o mobiliário, 0 instrumental, as atitudes e os métodos de trabalho próprios das relações de produção da arquitetura ${ }^{9}$. Isso, na visão dos autores do documento 'Prática-Investigação' ${ }^{10}$, representou uma tomada do espaço do ensino pela arquitetura, uma conquista na qual sobressaíam posturas de uma profissão até então não muito conhecida, que passou a ser respeitada pelos professores engenheiros.

Na prática dos anos 1960, porém, os cursos de arquitetura continuavam sob o controle majoritário dos engenheiros, o que se evidencia, por exemplo, no fato de que a FAU-USP teve diretores engenheiros até 1968. Essa dificuldade cotidiana na luta pelo espaço

\footnotetext{
${ }^{6}$ Fernandes, Ari, 1976 (b), anexo II: 07.

${ }^{7}$ Ibid.

${ }^{8}$ Ibid. Outros cursos pertencentes ao ICA adotaram também o modelo de Ateliê Central.

${ }^{9}$ Ibid.

10 Ibid.
} 
nas escolas de arquitetura, que representa luta pelo poder dos diversos setores envolvidos, esclarece por que tornou-se rapidamente palavra de ordem a idéia do 'Ateliê como espinha dorsal do curso de arquitetura'11, que fez parte de intenso debate no meio cultural vivenciado no Brasil. Mas com o golpe militar de 1964 iniciou-se um processo de tentativa de silenciamento.

Isso esclarece também o sentido da busca de um ensino crítico e transformador impresso no processo de reabertura da FAU-UnB - em meio à intensa repressão do governo militar - , forte influência para a FAU-SJ C, ambas inseridas nesse debate da formação do arquiteto, 0 que contribuiu para a realização nessa última faculdade, nas palavras de Guto Lacaz ${ }^{12}$, de um "laboratório de ensino".

\section{As críticas ao ateliê na FAU-SJ C}

A análise do Documento elaborado pelo Departamento de Tecnologia da FAU-SJ C em 1973 permite entender as idéias desse grupo na disputa que teve a Faculdade como palco. Uma disputa que abriu espaço para um debate baseado em diferentes leituras da realidade, como também sobre o que é arquitetura e seu ensino. Permeava também esse debate uma disputa pelo poder.

Expoentes desse debate eram Mayumi W. Souza Lima, vice-diretora da FAU-SJ C (1973-1974) e coordenadora do Departamento de Tecnologia (1972-1974) - cargo que havia ocupado também na FAU-Santos (1971)

- Rodrigo Lefèvre e Sergio Souza Lima, entre outros. As reflexões que nutriam o debate tiveram origem na FAU-Santos, em 1970, quando experiências de renovação no ensino de arquitetura se depararam com dificuldades, as mesmas que se verificavam na FAU-SJ $\mathrm{C}^{13}$.

\footnotetext{
${ }^{11}$ Fernandes, Ari, 1976 (b), anexo II: 07. Ver_também Millan, Carlos Barjas, 1962 revista Sinopses, 1993: 166 a 176 e Vilanova Artigas, 1974, revista Sinopses, 1993: 133 a 137.

${ }^{12}$ Lacaz, Guto,2007, entrevista concedida à autora em 2007.

${ }^{13}$ Muitos professores da FAU-Santos foram despedidos, após uma crise, em 1972, entre eles Mayumi e Sergio Souza Lima, Rodrigo Lefèvre e Francisco de Oliveira. Segundo Paulo
} 
O texto elaborado pelo Departamento de Tecnologia da FAU-SJ C levanta problemas vinculados ao funcionamento dessa Faculdade, mas que poderiam ser aplicados às demais escolas de arquitetura do estado de São Paulo, cada vez mais numerosas ${ }^{14}$. Os autores, considerando as discussões que estavam sendo processadas na Comissão de Estruturação, apresentaram esse documento frente à:

- perspectiva de implantação, em 1975, da Universidade do Vale do Paraíba, a partir da Fundação Valeparaibana de Ensino (FVE);

- ampliação de forma caótica, da FVE em São José dos Campos, de cursos isolados, fruto de esquecimento ou falta de explicitação dos objetivos iniciais da proposta do IPC.

Afirmam os autores que a educação institucionalizada é um dos meios que o sistema dominante utiliza para alcançar seus objetivos, embora as alterações no sistema educacional estejam sempre atrasadas em relação às transformações no sistema produtivo. A defesa de uma ampla reforma do sistema educacional no Brasil vincula-se diretamente à necessidade do ensino de se adequar às condições exigidas pela expansão capitalista e industrial do país ${ }^{15}$. "Mas, ainda assim, a aceitação de mudanças dentro do sistema educacional é um fato lento e penoso" ${ }^{\prime 16}$.

Muitas vezes, segundo os autores, os professores atuam em conformidade com as regras da sociedade, que vê como indesejáveis modificações mais profundas na esfera das relações sociais, enquanto considera benéficos os avanços tecnológicos, mesmo quando estes tornam obsoletas algumas formas de relacionamento social. Porém, até no Relatório do Grupo de Trabalho da Reforma Universitária do governo

Bastos, por considerá-los arquitetos e professores de grande capacidade, decidiu convidá-los para participar da FAU-SJC. O fato de alguns desses professores terem participado efetivamente da formação do ICA-FAU na UnB, convalidava ainda mais o convite. Entrevista à autora, 2006.

${ }^{14}$ Além de Santos, em São José dos Campos e Mogi das Cruzes abriam-se na época outras escolas particulares de arquitetura, entre outras, em Guarulhos, Campinas e uma segunda escola em Mogi das Cruzes.

${ }^{15}$ Departamento de Tecnologia, FAU-SJC, 1973: 04 (copiografado).

${ }^{16}$ Ibid. Grifos nossos. 
Costa e Silva pode-se ler que a Universidade é concebida como objeto e agente das mudanças necessárias à estrutura socioeconômica ${ }^{17}$.

Defende-se, no texto do Departamento de Tecnologia da FAU-SJ C, a idéia, ainda própria do desenvolvimentismo dos anos 1950/60, de que a educação, em especial a universitária, seria "eficiente para o desenvolvimento do próprio sistema econômico, social e político dominante e que mesmo para tanto tornou-se necessário repensar o ensino tradicional passivo, de transmissão de experiências, para outro ensino mais ativo e aberto"18.

Vem à tona o sentimento de medo e letargia que o contexto político estava impondo, quando se diz no documento que não há o que temer ou esconder ao se proporem transformações de um sistema. 0 próprio relatório de reforma do governo propunha que a Universidade tivesse uma ativa participação e que deveria ser o "lugar de confrontação dialética, onde o indivíduo se situa na sua circunstância histórica, proporcionando-Ihe [...] as categorias necessárias para a compreensão e a crítica do próprio processo cultural, e instância de reflexão sobre as condições e o sentido do desenvolvimento" ${ }^{19}$. Porém na prática do ensino observavam-se as dificuldades de aplicar as idéias aparentemente aceitas.

Esse momento foi também analisado por Edgard Graeff, já em 1970, no artigo 'Sobre a formação do arquiteto', no qual afirmava: “É perfeitamente compreensível que um resíduo de temor permaneça entre nós, como herança dos períodos agudos de repressão, mas não é lícito que se cultive o medo de manifestar o pensamento, principalmente quando se trata [...] de problemas que envolvem a própria sobrevivência do ensino superior. Na livre, aberta e franca discussão dos problemas profissionais e do ensino, o que se afirma não é alguma intenção subversiva, mas o desejo de diagnosticar [...] e

\footnotetext{
${ }^{17}$ Ibid. Não se pode deixar de observar aqui que as mudanças que o governo Costa e Silva estava propondo eram referentes à adequação do Brasil às transformações do capital mundial. ${ }^{18}$ Departamento de Tecnologia, FAU-SJC, 1973: 05 (copiografado).
} 
curar os males que se alojam no corpo da profissão e no seio da universidade. $\mathrm{E}$ de todos estes males, o pior, sem dúvida, reside na aceitação passiva do silêncio: fruto estéril da autocensura"20. Nesse mesmo artigo, Graeff opina que não se pode atribuir só à repressão as dificuldades referentes ao ensino de arquitetura, apesar das brutalidades cometidas contra as escolas, entre 1964 e 1968, que prejudicaram o processo de renovação do ensino e resultaram no afastamento de muitos dos mais ativos, inquietos e lúcidos professores $^{21}$.

\section{As dificuldades do diálogo}

Verificava-se na época uma certa homogeneidade de linguagem no meio acadêmico. Eram de uso comum, por parte de professores (e não só no Brasil), os termos pesquisa, análise, experimentação, metodologia, síntese, práxis, modelo. Mas isso indicava uma unidade de conceitos apenas aparente, pois nas escolas de arquitetura o confronto era evidente e questões de importância fundamental extraviavam-se em desgastantes discussões ${ }^{22}$.

Essa falta de diálogo é também tema de preocupação em Graeff, quando diz que na maioria das escolas os professores e estudantes não conseguiam estabelecer um diálogo aberto. Seja nas escolas, seja no $I A B$, a comunicação é dificultada como por barreiras ou muros de desconfiança: as linguagens usadas "parecem cifradas, feitas de sinalizações herméticas, densas de expressões de sentido dúbio. É como se temêssemos empregar as palavras para expor com clareza nossos pensamentos, como se nós as usássemos, de fato, para escondê-los. E assim a comunicação é quase impossível"23.

\footnotetext{
${ }^{19}$ Ibid: 06, apud texto da Reforma Universitária.

${ }^{20}$ Graeff, Edgard, 1970: 01 e 02.

${ }^{21}$ Graeff, Edgard, 1970: 02

${ }^{22}$ Departamento de Tecnologia, FAU-SJC, 1973: 06. Grifos nossos.

${ }^{23}$ Graeff, Edgard, 1970: 01.
} 
O texto do Departamento de Tecnologia da FAU-SJ C considerava que, nesses anos, a própria atividade profissional arquitetônica estava em discussão, fosse pelas diferentes auto-definições,

tais como artista, técnico, artesão, coordenador de equipes etc. e suas formas de atuação, fosse pelos resultados de pesquisas de mercado, discutíveis quanto aos critérios usados e às conclusões.

\section{Arquitetura e ensino}

A reflexão sobre ensino realizada pelo Departamento de Tecnologia da FAU-SJ C tomava como base as idéias de Paul Legrand, que comparava a educação de uma sociedade dinâmica com a de uma estática, na qual os padrões de conduta e os conhecimentos vinham do passado. Nesse sentido, os professores seriam os transmissores desses conhecimentos, necessários para que os alunos se transformassem em "iniciados". ${ }^{24}$ Correspondiam a essa idéia de educação, afirma o Departamento de Tecnologia, visões estereotipadas do professor (dono do saber) e do aluno (vazio de saber), estabelecendo-se critérios de avaliação que valorizavam a capacidade do aluno de maneira competitiva, tomandose como referência um modelo prefixado de um 'arquiteto' bemsucedido.

Esse tipo de ensino, ministrado de fora para dentro e de cima para baixo e que impunha ao aluno um saber acabado, provindo da autoridade profissional e da experiência, exagerava a importância do produto final e diminuía o valor do processo. Confundiam-se assim os objetivos-meios e os objetivos-fins da educação e impedia-se a participação mais ativa do aluno no próprio desenvolvimento ${ }^{25}$.

\footnotetext{
${ }^{24}$ Paul Legrand foi responsável pela Divisão de Educação de Adultos, setor da Educação. No ano de 1970 apresentou em Conferência da Unesco o relatório "Uma introdução à educação ao longo da vida”, segundo Amorin, Marlene Paula Castro, 2001. Também Paulo Freire cita Paul Legrand no livro Educação e Mudança, 1984: 67-68.

${ }^{25}$ Departamento de Tecnologia, FAU-SJC, 1973: 08
} 
$\mathrm{Na}$ crítica a esse tipo de processo, colocava-se uma outra visão de ensino entendida como formação contínua no percurso do indivíduo, passando o objetivo a ser o de "ensinar a aprender a estudar" por meio de experiências que, longe de completar-se em si mesmas, dariam origem a novas indagações em cada fase de crescimento do estudante, num ciclo contínuo de pesquisa. Os métodos para incentivar a participação do aluno aliavam formas de trabalho de equipe e individuais, aceitas e combinadas livremente pelo grupo, nas quais se incluíam a programação e os prazos para a realização de atividades.

Na visão do Departamento de Tecnologia, a educação ativa desenvolve a autodisciplina e uma atitude consciente e crítica da realidade, que abre espaço para a atividade criadora, e não para o individualismo anárquico, como propõem alguns. 0 ensino dinâmico substitui o julgar pelo diagnosticar, desenvolvendo nos estudantes a percepção do potencial da realidade analisada. Ao mesmo tempo avalia os resultados em cada fase e em cada curso para, nas fases seguintes, organizar programas adequados, o que só é possível quando o professor participa como co-responsável dos trabalhos de equipe e não cumpre somente 0 papel de gerente ${ }^{26}$.

Outro aspecto levantado pelo Departamento de Tecnologia é que o profissional (arquiteto, comunicador ou cineasta), ao fazer opção pela docência, acrescenta uma outra profissão específica, que demanda novos conhecimentos. Não se espera dele a transmissão mecânica de sua experiência (que pode ou não ser refletida em prêmios e publicações), válida e necessária porém não suficiente para descobrir e procurar conjuntamente novos caminhos para uma atuação transformadora sobre a realidade ${ }^{27}$.

\footnotetext{
${ }^{26}$ Departamento de Tecnologia, FAU-SJC, 1973: 09

${ }^{27}$ Ibid., grifos nossos. Poderá ser discutido em uma pesquisa futura o significado de “acrescentar”: se o professor-arquiteto deve assumir na íntegra os saberes pedagógicos ou se deve ser apoiado e assessorado por pedagogos, ou as duas possibilidades integradas. O Taller Total da FAU-UNC optou pela integração de uma equipe de pedagogos.
} 
Para os professores do Departamento de Tecnologia, o IPC representava um avanço frente à existência de escolas isoladas naquele momento, porém indagavam quais as possibilidades de a FAU-SJC poder cumprir suas funções se "os horizontes de crescimento não ultrapassarem os de uma agência de formação profissional ajustada ou não às necessidades da região em que se inserem" ${ }^{28}$.

\section{Arquitetura, urbanismo e contexto}

Esboça-se aqui uma das questões que tinham já provocado uma crise na FAU-Santos, mas que só pode ser entendida no contexto da época em relação às possibilidades de desenvolvimento da arquitetura e do urbanismo.

Nesses anos, na minha visão, o debate inicial, revelado no documento do Departamento de Tecnologia da FAU-SJC, revelava muitas vezes ausência de diálogo e polarização dos pontos de vista de cada setor. No entanto, as experiências de ensino desses anos constituíam um campo fértil para a elaboração de diversas idéias que fazem parte de uma polêmica que permanece aberta. Esse debate tinha como pano de fundo diferentes leituras políticas da realidade nacional, o que se refletia em diferentes propostas da arquitetura e seu ensino. Mas estavam presentes também questões não explicitadas, talvez pela mitificação do papel do arquiteto, e que diziam respeito à arquitetura como trabalho, ou seja, meio de sobrevivência.

A economia nas décadas de 1960-1970 estava em processo de concentração e internacionalização do capital, necessitando de mãode-obra qualificada ${ }^{29}$, condição na qual se incluem os arquitetos, questão que muitas vezes é negada, como se a arquitetura pairasse no ar, e fosse só um trabalho intelectual auto-suficiente.

\footnotetext{
${ }^{28}$ Departamento de Tecnologia, FAU-SJC, 1973: 10. Grifos nossos.

${ }^{29}$ Ver Parte II, Capítulo I desta tese.
} 
Essa época contraditória para a categoria dos arquitetos, entre outras da sociedade brasileira, é posta a nu no depoimento dado por Vilanova Artigas a Lívia Pedreira, ao relacionar arquitetura, sobrevivência e contexto político-econômico.

0 arquiteto cita, nesse depoimento, as possibilidades de desenvolvimento da arquitetura e urbanismo oferecidas pela época do "milagre brasileiro", período em que foi escrito o documento dos professores do Departamento de Tecnologia da FAU-SJC que se está analisando. Vários de seus autores haviam sido discípulos desse arquiteto na FAU-USP.

“O Al5 me mandou embora, mas não fui só. O Paulo Mendes da Rocha e o J on Maitrejean eram homens dignos. Ao ser cassado com eles, não puderam me cobrar posições políticas radicais, mesmo porque nunca as tive. Cassaram-me com pessoas dignas. [Depois do Al5] fiquei sem salário. Dei continuidade a meu trabalho [...] aproveitei-me um pouco do milagre econômico e durante esse período fiz algumas escolas e escrevi alguns artigos. [...] Para falar a verdade, sobrevivi. E, depois de cassado, vivi a década de 1970 cercado pelo medo. Desse período só me lembro do medo. Terror que fez meus colegas calarem a boca na universidade, e não os chamo de covardes por não terem protestado contra minha ausência. Para dizer a verdade, só agora começo a tomar conhecimento dessas coisas, do terror da época. Tive que reengolir esses terrores, inclusive para me submeter a este concurso, pois revi um monte de besteiras, sem qualquer conteúdo histórico ou político, para fazer um discurso bonito. Fatos como esses ilustram como viveram os intelectuais nos últimos vinte anos" ${ }^{30}$.

É preciso lembrar que em 1973 o crescimento econômico do país havia alcançado uma taxa superior a $10 \%$, enquanto Delfim Netto anunciava uma taxa inflacionária de pouco mais de 14\%. A indústria da construção, depois do período de quase paralisia dos anos 1964-1965, 
tinha sido ativada, sobretudo com a criação do BNH (em 1966) e o desenvolvimento de outras instituições estaduais como, por exemplo, a CECAP (Caixa Estadual de Casas para o Povo), autarquia estadual paulista, como parte de uma política do Estado para a construção de grandes obras, tais como conjuntos habitacionais, escolas, ginásios, hospitais, estações rodoviárias etc. Conseqüentemente, grande parte dos escritórios de arquitetos, entre os quais muitos eram também professores, estavam com bastante trabalho. Sabe-se hoje que o chamado 'milagre brasileiro' foi baseado em uma inflação retida e um desenvolvimento financiado por sucessivos empréstimos externos, com um custo social elevado, devido à crescente concentração de renda e à contenção salarial.

O Estado ditatorial que cassava direitos (inclusive de muitos arquitetos), que efetuava prisões, torturava e cerceava a liberdade de expressão era o mesmo Estado que possibilitava a ansiada produção habitacional em larga escala, e aparecia marchando para o progresso ${ }^{31}$.

Muitos arquitetos, em fins da década de 1960 e nos anos 1970, entre eles Paulo Bastos, coordenador do Departamento de Projeto da FAUSJ C, Vilanova Artigas, Paulo Mendes da Rocha - e mesmo outros que, como Paulo Bruna, tinham uma visão diferente da realidade acreditavam que poderiam ser desenvolvidas técnicas industriais e modernas na arquitetura para resolver questões de carência habitacional, entre outras, mesmo que num regime governamental autoritário.

Defendiam a idéia de que a pré-fabricação permitiria alcançar níveis de qualidade na habitação, por meio de uma construção honesta, racionalizada, acessível a todos e que correspondia aos conhecimentos técnicos do momento histórico. Dentro dessa idéia, as possibilidades econômicas de cada classe social não eram as principais determinantes.

\footnotetext{
${ }^{30}$ Depoimento a Lívia Pedreira, apud Xavier, Alberto, 2003: 223. Nele, refere-se ao concurso para Professor Titular realizado na FAU-USP em 1983.

${ }^{31}$ Ver Ermínia Maricato, 1976.
} 
E aqui se revela, tanto no projeto dos conjuntos habitacionais quanto no desenho industrial, a revalorização da Bauhaus, trazendo para 0 Brasil tardiamente os temas discutidos por ela nos anos 1920-1930, e não por acaso, já que o contexto industrializante da época permitiria sua aplicação.

A realidade, porém, demonstrou que as esperadas conseqüências progressistas do desenvolvimento das forças produtivas apresentavam limites: o Brasil produzia automóveis mas continuava aplicando técnicas atrasadas na construção civil, situação que se mantém até hoje.

A arquitetura, se por um lado progrediu na modernização das formas, continua distante da modernização das relações de trabalho e produção. Mantém-se ainda hoje uma oposição entre estética "arrojada" e canteiro de obras atrasado, inclusive nos casos dos chamados "prédios inteligentes" e da "tecnologia de ponta".

A maioria dos professores que compunham o Departamento de Tecnologia e o de História na FAU-SJ C alinhava-se com uma visão que, no Brasil, vinha sendo elaborada principalmente na FAU-USP e na FAUSantos e estava inserida no debate latino-americano revelado já em 1963, na reunião da UIA (União Internacional de Arquitetos), realizada em Cuba. Esses profissionais avaliavam que não havia no país possibilidades de industrialização da construção devido à grande disponibilidade de mão-de-obra barata. Achavam que se deveria adotar sistemas construtivos atrasados que, a partir do domínio popular, avançariam na medida do possível, seja com simples racionalização, seja com pré-fabricação in loco, atendendo à construção em massa e também à conscientização dos operários.

O movimento cubano das microbrigadas dos anos 1970 foi forte referência para esses arquitetos. Roberto Segre afirma que as microbrigadas fortaleceram o poder popular com uma "entusiasmada participação dos trabalhadores na materialização das estruturas 
urbanas e arquitetônicas [...] na configuração do ambiente na sua gestão"32. Mas o autor adverte que a idéia de participação não conseguiu alcançar um vínculo entre projetista e usuário, pela falta de quadros e pelas soluções padronizadas e pré-fabricadas, que afastavam 0 arquiteto da comunidade. Para Segre, as experiências mais artesanais, "embora tenham demonstrado um menor rendimento econômico [...] foram mais positivas quanto à participação, educação técnica, trabalho coletivo e consciente" ${ }^{33}$.

Anos mais tarde essa opção será defendida por Rodrigo Lefèvre na dissertação de mestrado "Projeto de um acampamento de obra: uma utopia", na qual propõe o canteiro-escola inspirado em Paulo Freire. Para esse arquiteto-professor, as formas de produção artesanais de arquitetura (autoconstrução generalizada, que inclui também os mutirões), mesmo precárias, seriam vantajosas por serem mais conscientizadoras e tecnicamente mais criativas, devido à possibilidade de diálogo entre mutirantes e arquitetos. No entanto, no mesmo ano da defesa de sua dissertação, Rodrigo Lefèvre escreve o 'Arquiteto assalariado', refletindo sobre seu trabalho na Hidroservice, com um caráter diferente dos mutirões, de que se falará adiante. A polêmica pré-fabricação-mutirões, iniciada em fins da década de 1960, continua em aberto, como o demonstra o ciclo de debates realizado na FAU-USP em 2004.

Nesse evento, Francisco de Oliveira pronunciou uma conferência na qual propunha-se discutir "os processos de autoconstrução, esse calcanhar-de-aquiles do movimento habitacional", afirmando que a elaboração de sua abordagem sobre as relações entre os processos de acumulação de capital no Brasil e a autoconstrução urbana fora resultado do contato com arquitetos na FAU-Santos ${ }^{34}$. Essa ligação

\footnotetext{
${ }^{32}$ Segre, Roberto, 1991: 198-202.

33 Ibid.: 202.

${ }^{34}$ Oliveira, Francisco, “O vício da virtude”, 2006.Conferência apresentada no seminário de pesquisa "Políticas habitacionais, produção de moradia por mutirão e processos
} 
surgiu quando um grupo de arquitetos e alguns sociólogos, empenhados numa "fase missionária", passaram a fundar escolas de arquitetura e urbanismo por todo o estado de São Paulo.

Na FAU-Santos, havia um grupo muito interessante, formado pelos arquitetos Sergio Ferro, Rodrigo Lefèvre, Sergio e Mayumi Souza Lima e pelos sociólogos, Francisco de Oliveira, Gabriel Bolaffi e Danielle Ardaillon. Os arquitetos realizaram junto com os alunos uma pesquisa sobre habitação popular, em que se constatou que a "casa própria" construída em mutirões ou pelo sistema de autoconstrução informal era a realidade da grande maioria. Francisco de Oliveira, apoiado nos resultados da pesquisa, comentou: "Mutirões da tradição: você chama 0 compadre no fim de semana, toma uma cerveja, come uma lingüiça frita e vai fazendo a casa aos pouquinhos. Caiu a ficha. Crítica à razão dualística partiu dessa constatação [...]: a industrialização estava se fazendo com base na autoconstrução, como um modo de rebaixar 0 custo de reprodução da força de trabalho"35.

Para 0 autor, a industrialização brasileira foi firmada por duas vertentes: a estatal, pela qual o Estado subsidiava a implantação industrial transferindo renda de certos setores; e a outra, gerada com recursos da própria classe trabalhadora, que ao autoconstruir sua habitação, rebaixava o custo de reprodução. "O capital se reproduz com o rebaixamento do custo da força de trabalho ou, em outras palavras, com o rebaixamento do salário"36.

Oliveira problematizou o papel dos mutirões no contexto das estratégias para resolver o problema da habitação no Brasil, argumentando que o barateamento da força de trabalho por meio da autoconstrução resultou nas nossas periferias: aglomerações infernais, onde não há fronteiras entre a vida privada e a promiscuidade.

autogestionários: balanço crítico de experiências em São Paulo, Belo Horizonte e Fortaleza”, realizado na FAU-USP em outubro de 2004.

${ }^{35}$ Oliveira, Francisco, 2006: 03.

${ }^{36}$ Ibid.: 04. 
Esse debate, que perpassou várias experiências de ensino, entre elas as da FAU-Santos e a FAU-SJ C na década de 1970, e o Laboratório de Habitação da Belas Artes nos anos 1980, deve ser aprofundado, ainda hoje.

Se em 1965 o déficit habitacional era de 8 milhões de unidades habitacionais, em 1981 era oficialmente calculado em 7 milhões: ou seja, em dezesseis anos, a solução do problema tinha atingido menos de $13 \%$.

Nesses anos, muitos dos professores-arquitetos das faculdades de arquitetura estavam desenvolvendo em seus escritórios grande quantidade de projetos, contratados na sua maioria pelo Estado. E 0 IAB tinha, de acordo com o caráter inerente a uma organização representativa de uma categoria profissional, atuado no sentido de abrir novas possibilidades. Esse também era um dos motivos pelos quais 0 IAB dava apoio à abertura de novas escolas no interior de São Paulo, já que por meio de seus professores, a maioria originários da capital, abriam-se novos campos de contratação de projetos e obras ${ }^{37}$. Já os arquitetos que questionavam mais a fundo o significado da produção habitacional por um Estado ditatorial e anti-social, não acreditando na possibilidade de algum setor da burguesia nacional investir na pré-fabricação, acusavam o setor hegemônico do IAB de "vender-se por migalhas". Essa crítica era parte do pano de fundo da controvérsia que começou na FAU-USP em 1968 entre Vilanova Artigas seus discípulos (como visto no capítulo III, parte II) e perpassou pela FAU-Santos e a FAU-SJ C, nesta última talvez de forma ainda mais acirrada.

Um debate que, na minha opinião, ao polarizar-se e exagerar as posições, fechava a possibilidade de diálogo. Isso contribuiu para deixar em aberto o verdadeiro debate sobre a arquitetura e seu ensino. O que era para ser uma discussão entre setores do mesmo campo, entre

\footnotetext{
${ }^{37}$ Fernandes, Ari, 2006, entrevista concedida à autora.
} 
"amigos", converteu-se muitas vezes numa guerra que perdia de vista 0 inimigo principal, que na época era a ditadura. Entretanto, nos momentos mais duros da repressão, as partes foram solidárias entre si.

\section{Paulo Freire, arquitetura e ensino participativo}

Perpassa pelo documento que se está analisando a forte preocupação pedagógica, compartilhada pela maioria dos professores dos Departamentos de Tecnologia e de História ${ }^{38}$. Essas preocupações nasceram já em 1962, com a participação de Mayumi e Sergio Souza Lima no ICA-FAU da UnB organizada por Darcy Ribeiro e outros intelectuais. Em Santos, Mayumi e Sergio junto a Sergio Ferro, Rodrigo Lefèvre e Francisco de Oliveira, entre outros, contribuíram na elaboração de uma nova estrutura de ensino.

Mas foi na FAU-SJ C que essas idéias tiveram possibilidade de se desenvolver, num processo mais extenso que os anteriores, porém em "permanente crise".

Paulo Freire foi também uma influência forte nessa nova proposta de ensino, que propunha relacionar realidade, técnica e necessidades da maioria da população. A referência a ele está implícita na vontade de encontro com o povo.

“Paulo Freire iluminou os espaços da educação, considerando-os como relação interativa que transcende o espaço formal e atinge o informal na 'cidade que se alonga como educativa'. De igual maneira ele inspira a possibilidade de uma articulação onde a prática pedagógica interativa e dinâmica se entrelaça com uma forma de agir do arquiteto na sociedade, dialógica, interativa e que procura construir um projeto

\footnotetext{
${ }^{38}$ Paulo Bastos, afirmou em depoimento à autora (2006) que "o grupo de Mayumi W. Souza Lima tinha muitos conhecimentos de pedagogia e era muito preocupado com essa questão”. A experiência dessa arquiteta, voltada fortemente para Educação, abrangendo desde o nível primário até o universitário, é manifesto no seu curriculum vitae. Ver: Souza Lima, Mayumi W, 1995: 243 a 259. Também ver revista CJ Arquitetura, revista de planejamento e construção $\mathrm{n}^{\mathrm{o}} 4,1974$, dedicada ao ensino de arquitetura, contendo artigos de, entre outros, Mayumi Souza Lima, Paulo Bruna, Ari Fernandes e Nestor Goulart Reis Filho.
} 
participativo dos espaços, vendo o homem como um ser de relação 'não apenas no mundo, mas com o mundo'"'39.

Esse educador traz elementos importantes para a reflexão quando fala nas "relações entre educação, enquanto processo permanente, e a vida nas cidades, enquanto contextos que não apenas acolhem a prática educativa como prática social mas também se constituem, através de suas múltiplas atividades, em contextos educativos em si mesmos" ${ }^{40}$. A leitura da cidade, tão necessária à ação do arquiteto e à do estudante de arquitetura e urbanismo, revela, para Paulo Freire, o olhar que "destrincha ou esmiúça a sua significação mais íntima, expressa ou explicita a compreensão do mundo [...] a inteligência da vida na cidade, o sonho em torno desta vida, tudo isso grávido de preferências políticas, éticas, estéticas e urbanísticas de quem o faz"41.

Na FAU-SJ C, seja no IPC, seja nas UIDs (unidades interdepartamentais), das que se falará adiante, a ação educativa, considerada uma relação de diálogo, tinha como objeto de estudo e de intervenção a cidade e propunha que o arquiteto tivesse com ela uma relação de interação, e não fosse apenas um observador distante, que visse a cidade como objeto.

A experiência do IPC nas turmas do primeiro semestre, vista no capítulo anterior, coincide plenamente - mesmo que de forma não explícita com a proposta de Paulo Freire de "surpreender a cidade como educadora [...] e não só como o contexto em que a educação se pode dar, formal e informalmente" ${ }^{42}$. Nesse sentido, as práticas da FAU-SJC coincidiam com as do Taller Total da FAU-UNC, nos mesmos anos.

Outra questão em pauta era a mudança do perfil do arquiteto, que a sociedade estava demandando.

\footnotetext{
${ }^{39}$ Pronsato, Sylvia A. Dobry, 2005: 49.

${ }^{40}$ Freire, P., 1997: 16.

${ }^{41}$ Freire, P., 1997: 16. O tema da relação entre arquitetura e urbanismo e seu ensino e Paulo Freire foi tratado pela autora, 2005: 45 a 72. Também Arantes, Pedro trata da influência de Paulo Freire em Rodrigo Lefèvre, professor da FAU-SJC, entre outras, 2002: 140.

${ }^{42}$ Freire, P., 1997: 18.
} 


\section{O novo perfil do arquiteto a partir dos anos 1970: desmistificando a profissão}

A arquitetura e o urbanismo fazem parte do modelo de desenvolvimento econômico da sociedade. Assim, em coerência com os rumos tomados pelo capital no mundo e no Brasil, nos anos 1970 aparecem novas modalidades do exercício da profissão de arquiteto. 0 seu reflexo no ensino de arquitetura e urbanismo não é geralmente explicitado até hoje. Nas FAUs Santos e SJ C, esse tema permeou o debate sobre arquitetura e seu ensino, pelo que considero pertinente estender-me sobre ele.

As grandes empresas de arquitetura e planejamento urbano aparecem nos anos 1970 como conseqüência das importantes obras públicas contratadas durante o governo militar, tais como conjuntos habitacionais, aeroportos, hospitais, escolas, barragens, usinas, pontes, portos, planos diretores, novas cidades etc.

A produção de projetos de forma considerada artesanal, representada pelos ateliês ou escritórios dos arquitetos enquanto profissionais liberais, ficava defasada frente à nova racionalidade que as grandes empresas estabeleciam. Isso porque, ao concentrarem nelas muitos profissionais assalariados, conseguiam melhorar os processos de trabalho, respondendo às demandas públicas de maneira mais apropriada.

Essas empresas, porém, tiveram pouca duração, já que se extinguiram junto com as grandes obras dos anos 1970, quando, com a crise das décadas de 1980 e 1990, houve mudanças frente às demandas públicas. A "flexibilização da produção", que, em outras palavras, constituía a terceirização e depois até a quarteirização inaugurou a formação de empresas menores ligadas por gerenciadoras de projetos $^{43}$.

\footnotetext{
${ }^{43}$ Este tema foi desenvolvido por Arantes, Pedro, 2002: 142-156. Há uma história a ser escrita que relacione os diferentes níveis de atuação dos arquitetos por meio de seus organismos
} 
Essas alterações na produção de arquitetura e urbanismo se refletem na mudança do perfil do arquiteto.

No texto "Sobre a formação do arquiteto", já anteriormente citado, o arquiteto Edgard Graeff ${ }^{44}$, que foi professor no ICA-FAU da UnB até 1964, fez uma análise que foi referência importante para muitos dos professores da FAU-SJ C, entre eles Mayumi W. Souza Lima, Ari Fernandes, Rodrigo Lefèvre, Ermínia Maricato, Horácio Morita, como também para muitos estudantes, como I ves de Freitas, Monica Nadar, Yara Vicentini, entre outros.

Para Graeff, as tarefas atribuídas ao arquiteto dependem da realidade social da qual decorre a realidade profissional, que não pode ser confundida com mercado de trabalho nem com modalidades de profissionalização assumidas pelos arquitetos sob pressão do próprio mercado. Esse seria um equívoco a obscurecer a já nebulosa problemática do ensino.

O mercado de trabalho tem uma ação direta e imediata sobre o ritmo da atividade produtiva de um arquiteto e sua vida cotidiana; porém esse mercado mascara a realidade do campo da arquitetura ${ }^{45}$. Isso porque, para esse autor, nas condições do Brasil de fins das décadas de 1960 e 1970, os arquitetos incluíam-se (e na minha visão ainda hoje é assim) em quatro modalidades de profissionalização:

1. O profissional liberal ou autônomo ao estilo tradicional. Essa modalidade é o sonho dourado da maior parte dos arquitetos: trabalhar só em seu ateliê ou em equipe com outros arquitetos da mesma condição, com a colaboração de desenhistas, quase sempre estudantes, aprendizes. Lá, ele poderia - teoricamente menos vinculado a compromissos externos à atividade criadora - realizar obras que refletissem suas idéias e sua personalidade. Porém, já arquitetura e urbanismo no Brasil a partir dos anos 1970.

${ }^{44}$ Edgard Graeff, a respeito de suas obras arquitetônicas pode-se consultar Xavier, Alberto e Mizoguchi, Ivan, Arquitetura moderna em Porto Alegre. São Paulo, FAU-UFRGS-Pini, 1987. 
nos anos 1970, essa modalidade oferecia perspectivas para uma ínfima minoria de arquitetos. E, concordando com Graeff, essa categoria não pode ser confundida com a daqueles que, tendo apoio suplementar em outras fontes de renda, constituem a grande maioria dos profissionais liberais do Brasil: uns se dedicam a negócios paralelos, como por exemplo transações imobiliárias, comércio de equipamentos e materiais ou de móveis, indústria da construção etc. Outros dispõem de rendimentos produzidos por bens de raiz, imóveis ou se apóiam em atividades assalariadas de tempo parcial, como emprego público ou em empresa, docência etc. Essas situações descritas acima podem ser consideradas híbridas: umas derivam de privilégio, outras da penúria ${ }^{46}$.

2. O arquiteto empresário, individual ou associado: nesse caso, o escritório deve ganhar o suficiente para cobrir despesas de instalações, material, salários dos funcionários e sócios, além dos lucros. No Brasil, em geral as pequenas firmas de arquitetos não conseguem assegurar um fluxo contínuo de trabalho, flutuando entre períodos com alto volume de projetos com solicitação de entrega a curto prazo e outras fases, às vezes longas, de ociosidade. Na década de 1970 aprofundou-se a formação de grandes escritórios que refletiam a política de concentração de recursos exercida pelo governo. Para órgãos como, por exemplo, SERPHAU ou BNH, repartições públicas ou grandes empresas, não era suficiente a garantia do talento e do currículo dos profissionais. Eles queriam escritórios que oferecessem capital, equipamentos e instalações e garantissem os prazos estipulados ou o pagamento das multas acordadas. Nessa modalidade, muitas vezes, a realização criativa do arquiteto-patrão ficava comprometida pelas preocupações financeiras e administrativas ${ }^{47}$.

\footnotetext{
${ }^{45}$ Graeff, Edgard, 1970: 03.

46 Ibid.: 05.

${ }^{47}$ Graeff, Edgard, 1970: 09.
} 
3. O arquiteto assalariado: em decorrência da formação de grandes escritórios que concentravam a produção de projetos de arquitetura e urbanismo, muitos arquitetos passaram a ser empregados dessas firmas. A relação entre arquitetos-patrões e arquitetos-assalariados já vigorava nos países capitalistas centrais, quando começou no Brasil.

Rodrigo Lefèvre, por exemplo, professor da FAU-USP, FAU-Santos e FAU-SJ C, da PUC de Campinas, onde foi diretor, e da FAU-Belas Artes, em São Paulo, é um dos arquitetos que passaram a se incluir na categoria profissional assalariado a partir de 1972, ao ser contratado pela Hidroservice, uma grande empresa de projetos, na qual trabalhou até sua morte, em $1984^{48}$. Nessa empresa exercia a coordenação de projetos. Entre eles, os do Instituto dos Ambulatórios do Hospital das Clínicas, em São Paulo (1975), do Edifício Sede do DNER em Brasília (1973), da Fábrica de Combustíveis da Nuclebras (1978), do Terminal Rodoviário Tietê, em São Paulo, de projetos na Nigéria(1980-1981) e em Guiné Bissau (1983).

Em 1981, escreveu um artigo para a revista Módulo, no qual avaliava o trabalho assalariado numa empresa de projetos ${ }^{49}$. Nele destaca a oportunidade de trabalhar em equipe, com profissionais de várias áreas interagindo num projeto: um processo de criação coletiva em oposição ao da criação impenetrável e genial do grande arquiteto. Lefèvre, ao contrário de outros arquitetos, que viam no assalariamento o fim da criatividade e da independência do arquiteto, considerava a "proletarização" dessa profissão uma possibilidade de democratização. Mas era uma democratização restrita aos técnicos, não se podia estendê-la ao canteiro de obras. A atividade projetual do arquiteto passava a ser debatida com os profissionais das equipes multidisciplinares.

\footnotetext{
${ }^{48}$ Ver Arantes, Pedro F., 2002: 150 a 156. Ver também Koury, Ana Paula, 2003.

49 “O arquiteto assalariado”, revista Módulo, n 66, 1981: 68 a 71.
} 
Porém, em entrevista a Renato Maia ${ }^{50}$, ressalta que, nessas equipes multidisciplinares, o arquiteto é o único ainda a ter uma visão "global e universalista", ficando responsável pelo plano geral e as diversas colaborações. Mantém-se aqui a idéia de Gropius, primeiro diretor da Bauhaus, do arquiteto como diretor de orquestra.

Para Lefèvre, a grande empresa abria a possibilidade para 0 desenvolvimento de uma tecnologia nacional de construção e para o conhecimento sobre a produção de projetos. Em outras palavras, ensejava a formação de um corpo técnico qualificado que respondesse aos complexos problemas que o Estado desenvolvimentista demandava. Lefèvre avaliava que, sem a constituição desse corpo técnico, acabaríamos por importar e adaptar projetos, previsão que se concretizou com o fechamento dessas empresas a partir da década de 1990.

Outra questão privilegiada por Lefèvre, ao projetar obras tais como o Instituto dos Ambulatórios do Hospital das Clínicas, era o conceito de servir às necessidades do usuário: como o prédio poderia atendê-lo da melhor forma possível, como planejar adequadamente o espaço para os profissionais que lá iriam trabalhar, quais os materiais mais duráveis etc.

No entanto, apesar dos aspectos positivos apontados acima, não é possível ignorar que, no capitalismo, as relações estabelecidas entre os profissionais da arquitetura para sua produção, diferem de como elas se davam no Renascimento, na Idade Média e até na Antiguidade - épocas em que as relações entre mestres e aprendizes eram marcadas por uma hierarquia de conhecimento ${ }^{51}$.

No sistema atual, muitos dos arquitetos-proprietários são menos qualificados que os profissionais assalariados, que, como registrava

\footnotetext{
${ }^{50}$ Entrevista a Renato Maia apud Koury, Ana Paula, 2003.

${ }^{51}$ Graeff, Edgard, 1970: 07.
} 
Graeff já em 1970, permanecem muitas vezes no anonimato, enquanto os primeiros aparecem como os autores de excelentes projetos que mal conhecem.

Quando o arquiteto é funcionário de construtoras nem sequer pode ter, na maior parte dos casos, a satisfação de acompanhar a transformação do projeto em obra. Isso porque nas construtoras o que é privilegiado são os interesses da indústria e do comércio da construção, os quais raramente coincidem com a busca de qualidade arquitetônica $^{52}$.

4. O arquiteto funcionário público: em geral, tanto no Brasil quanto em outros países, desenvolvidos ou não, o trabalho do arquiteto nas repartições públicas tende a assumir caráter burocrático e administrativo. A política de Estado no Brasil das décadas de 1960-1970 visava fortalecer prioritariamente os setores privados. Conseqüentemente, em geral os profissionais responsáveis por projetos de arquitetura e planejamento urbano dentro das repartições públicas exerciam apenas funções administrativas e de fiscalização, e não de criação ${ }^{53}$.

Hoje soma-se a isso, como diz Raul Pereira, "a debilidade de nossas estruturas administrativas, no sentido de garantir a permanência de projetos significativos [...]. Trata-se de uma questão recorrente nos programas, obras e projetos desenvolvidos pelo poder público brasileiro, tanto na esfera do executivo municipal como na estadual e federal" ${ }^{54}$. Outro aspecto refere-se à correlação de forças sociais, culturais e políticas, que em determinados momentos pode aprofundar ou esvaziar o espaço reservado a projetos e obras significativas para a paisagem das cidades.

\footnotetext{
52 Ibid.: 08.

53 Ibid.: 09.

${ }^{54}$ Pereira, Raul, 2006: 159.
} 
Mas, por outro lado, trabalhar em órgãos públicos oferece ao arquiteto a possibilidade de enfrentar escalas maiores, dificilmente assumidas por escritórios ou empresas.

Mayumi Souza Lima é um dos exemplos de arquitetos que desenvolveram intensamente atividades também nos órgãos públicos, de maneira criativa e eficiente, experiência que se refletiu em sua atividade docente, enriquecendo-a, segundo a maioria das fontes consultadas.

Mas, por ser arquitetura e urbanismo uma profissão dependente do contexto econômico, social, cultural e político para sua realização, como destacou Graeff, com raríssimas exceções, os arquitetos "passaram a se dedicar quase exclusivamente aos problemas imediatos do trabalho e, em especial, ao maior deles: o problema de arranjar trabalho" 55 .

\section{A estrutura organizacional}

A respeito da estrutura organizacional da FAU-SJ C, no texto elaborado pelo Departamento de Tecnologia para o Fórum de Debates de junho de 1973, afirma-se que a solução do IPC assumiu o modelo proposto pela Reforma Universitária, aplicada pela primeira vez em 1962 em Brasília, que tem como referência experiências de outros países e que se repetira, quase sempre só formalmente, na quase totalidade das universidades no Brasil. Ou seja, o IPC, aparentemente muito avançado, na realidade obedecia ao modelo defendido pela Reforma Educacional vigente ${ }^{56}$, instaurada pelo governo militar. Cabe aqui, na minha visão, lembrar que essa reforma começou a ser estudada com a contratação, pelo MEC, do assessor americano Atcon em 1956, oito anos antes do golpe militar de 1964. Já no final do período nacional desenvolvimentista o modelo de universidade cuja

${ }^{55}$ Graeff, Edgard, 1970: 15. 
forma final foi apresentada em 1968, indicava, por um lado, que para o governo militar a instituição universitária possuía ainda importância e prestígio e, por outro, que o desenvolvimentismo teve continuidade no governo militar, não atuando apenas como oposição, como pareceria à primeira vista. Porém, o novo Estatuto de 1970 da UnB dava um outro rumo à Universidade, abandonando definitivamente o compromisso com as concepções originais que até então tinham-se mantido, assumindo objetivos de racionalidade e eficiência. Talvez por esse motivo, o Departamento de Tecnologia da FAU-SJ C considerasse ainda válida a organização do IPC FAU-SJ C, mas esclarecendo seu vínculo originário e argumentando que esse tipo de organização propunha ainda um progresso, ao dizer:

“O avanço que propõe o IPC poderia, porém, ser metodológico, isto é, na compreensão e análise do processo de produção de mercadorias e ideologias que levam à reprodução do sistema e suas contradições. Nesse sentido, a amplidão das áreas que transformam o IPC numa mini-universidade poderia justificar-se, por permitir melhor apreensão do processo referido" $" 57$.

O Departamento de Tecnologia da FAU-SJC afirma que a diretriz única seria a apreensão do processo, sobre o qual se programariam as atividades do(s) instituto(s) e das escolas profissionais, já que o profissional de arquitetura tem um instrumental técnico e teórico diversificado dos profissionais de som ou de cinema.

O texto do Departamento destaca também as dificuldades de implantação originadas no objetivo básico do IPC, já que cada equipe de professores correspondente a cada área deveria adotar o mesmo método de análise global, levando em conta, no entanto, os objetos específicos e as técnicas. No dizer dos autores, "não se poderia

\footnotetext{
${ }^{56}$ Departamento de Tecnologia, FAU-SJC, 1973: 10.

${ }^{57}$ Departamento de Tecnologia, FAU-SJC, 1973: 11.
} 


\section{supor a divisão entre a reflexão histórica e o fazer técnico na própria atividade de projeto" ${ }^{58}$.}

Nessa idéia se revela a crítica a muitos professores do Departamento de Projeto da FAU-SJ C, que viam a atividade projetual como patrimônio exclusivo desse departamento ${ }^{59}$. 0 que se contrapõe à opinião de que a ação projetual é síntese de um processo no qual intervêm todos os departamentos. Nessa controvérsia, estabeleceu-se uma luta de poderes, como também aconteceu na FAU-UNC (Córdoba, Argentina). Na FAU-SJ C esse debate virá a tona ainda no início de 1973.

Os Grupos de Trabalho, que se haviam formado levados pelo descontentamento com a redução da proposta inicial do IPC, fundiramse na Comissão de Reestruturação da Proposta Básica do IPC, com a participação de professores e estudantes (paritária).

Em meados de 1973, essa Comissão, com base na crítica aos modelos anteriores $^{60}$ e no estudo de suas variações possíveis, apresentou alternativas. E preparou, em setembro desse mesmo ano, os princípios do sistema de Unidades Interdepartamentais de Ensino e Pesquisa.

Configurou-se um período de transição, com a implantação de apenas cinco unidades ${ }^{61}$. Os professores que discordavam desse modelo se afastaram, entre eles Paulo Bastos ${ }^{62}$; outros que 0 aprovavam, considerando-o viável, na prática fizeram uma "resistência velada" que dificultou sua implantação.

A proposta das Unidades Interdepartamentais de Ensino e Pesquisa na FAU-SJ C, assim como a do "Taller Total" na FAU-UNC, a meu ver, surgem como opções superadoras da distorção proveniente da hegemonia de um dos departamentos sobre os outros. Desenvolve-se, nessas alternativas, a prática projetual como produto e processo

\footnotetext{
${ }^{58}$ Ibid.: 12, grifo nosso.

${ }^{59}$ Isso também acontecia nas FAUs USP, Santos e hoje na maioria das escolas de arquitetura no Brasil e na América Latina.
} 
dialético de todos os conhecimentos de arquitetura e urbanismo e sua relação com o meio.

\section{As Unidades I nterdepartamentais de Ensino e Pesquisa (UI Ds)}

O sistema de Unidades Interdepartamentais de Ensino e Pesquisa resultou, entre outras correlações, da forte influência das idéias de Sergio Ferro sobre muitos professores da FAU-SJ C, entre eles Rodrigo Lefèvre. Desde 1972, Sergio Ferro era catedrático da Ecole d'Architecture de Grenoble ${ }^{63}$, na França. Nesse país, como produto da mobilização estudantil de 1968, o ensino de arquitetura e urbanismo sofreu modificações. Foram criadas Unidades Pedagógicas em Paris e outras cidades, entre elas Grenoble, como alternativa à Escola de Belas Artes $^{64}$.

O sistema de Unidades Pedagógicas em Grenoble relacionava disciplinas obrigatórias, optativas e laboratórios.

Nos dois últimos anos ( 30 ciclo) dava-se maior ênfase às atividades de pesquisa nos laboratórios, com caráter interdisciplinar, que por sua vez alimentavam as disciplinas de todos os $\operatorname{ciclos}^{65}$.

Na FAU-SJ C, as UIDs levavam em conta:

- "a luta dos arquitetos por um ensino adequado para a sua formação necessariamente de sintetização, que também significa a compreensão das partes em seu relacionamento entre si e no todo, luta esta bastante longa e que faz parte da existência do IAB e das escolas de arquitetura no país;

- a reivindicação estudantil no sentido da participação direta e ativa;

\footnotetext{
${ }^{60}$ Crítica ao Documento Básico do IPC, elaborado pela Comissão de Reestruturação da Proposta Básica do IPC, FAU-SJC, 1973.

${ }^{61}$ Fernandes, Ari e outros, 1976 (b): 16. Também Freitas, Ives de, 2007, entrevista à autora.

${ }^{62}$ Em ofício encaminhado ao Conselho Departamental da FAU-SJC, com data de 12/07/1973, o arquiteto Bastos pede licença por seis meses. Assume a diretoria do Departamento de Projeto, no seu lugar, José Eduardo de Assis Lefèvre.

${ }^{63}$ Koury, Ana Paula, 2003: 129. Depois de ser preso pelo regime militar por um ano, Sergio Ferro muda-se para a França.

${ }^{64}$ Heck, Carlos H., 2006, depoimento à autora.
} 
- as novas condições da realidade nacional e profissional;

- a necessária integração docência-pesquisa e não de cursos de mera transmissão de informações;

- a reivindicação docente - particularmente dos jovens arquitetos no sentido de ampliar seu tempo de dedicação à atividade docente;

- a necessidade de formar quadros docentes para o ensino da arquitetura, somente possível quando houver profissionais em condições de se preocuparem prioritariamente com o ensino, em contato permanente com o corpo discente, dedicados ao estudo aprofundado de um aspecto do trabalho profissional, transformado em tema globalizador sem compromisso de prazo e resultado imediato;

- $\quad$ interesse na troca de experiência e contato entre a população local e a população escolar;

- as dificuldades - ou até indigência - das condições materiais, financeiras e técnicas da maioria das escolas existentes, que leva a defender uma solução não onerosa e possível de se implantar gradativamente;

- a defesa pela transformação das escolas isoladas em unidades componentes de uma universidade" ${ }^{\prime 66}$.

O sistema de UID não estabelecia um modelo único de profissional a ser formado, dando-se ênfase ao processo de educação do indivíduo além da atuação profissional. Pretendia-se que os professores e estudantes desenvolvessem a capacidade de selecionar informações, fazer uma análise crítica e identificar meios e momentos de soluções adequadas para mudanças desejadas e necessárias.

Postulava o pensar para propor e não só saber fazer; ultrapassar os limites de um treinamento específico profissional dado por um

\footnotetext{
${ }^{65}$ Heck, Carlos H., 2006, depoimento à autora.

${ }^{66}$ Fernandes, Ari e outros, 1976 (b): 16 e 17. O tema das UIDs na FAU-SJC consta desse trabalho: 16 a 23 e anexo V: 01 a 05.
} 
condicionamento empírico, alheio à realidade política social e econômica ${ }^{67}$.

Os postulados do IPC não diferiam substancialmente das idéias colocadas acima. A diferença principal centrava-se na participação equilibrada dos três departamentos em todas as unidades. Isto, na visão do Departamento de Tecnologia, garantia a interdisciplinaridade. Para ele, o elemento unificador era o objeto de pesquisa, não o tema. O processo era considerado mais importante que o produto final. A interdisciplinaridade era o ponto obrigatório de todas as atividades das UIDs no curso de graduação e no de pós-graduação (que não chegou a concretizar-se) e das atividades com a comunidade ${ }^{68}$.

Propunha-se congregar as áreas do conhecimento como instrumento de investigação-pesquisa-prática durante todo o curso, por meio das seguintes UIDs:

“UID-1 - Sistema de Produção, Distribuição e Consumo (básico)

UID-2 - I deologia e Produção

UID-3 - Tecnologia e Produção (básico)

UID-4 - Meios de Produção e Circulação (profissional)

UID-5 - Meios de Consumo Coletivo (profissional)

UID-6 - Meios de Consumo Individual (básico e profissional)

UID-7 - Objeto e Mercadoria (básico e profissional)

UID-8 - Meios de Comunicação Visual e Sonora (básico)

UID-9 - Cidade e Região (profissional)

UID-10.1 - Estrutura e Projeto (básico e profissional)

UID-10.2 - Infra-estrutura e Projeto (básico e profissional)"69

Cada unidade apoiava-se em várias disciplinas para desenvolver 0 recorte proposto, o que permitiria elaborar determinados temas (hospitais, habitação popular etc.) relacionados à região ou à cidade de

\footnotetext{
${ }^{67}$ Fernandes, Ari e outros, 1976 (b): 17

68 Ibid.: 17.

${ }^{69}$ Fernandes, Ari e outros, 1976 (b): 19.
} 
São José dos Campos $^{70}$. As equipes eram compostas por alunos de todos os semestres, exceto do primeiro, considerado básico, no qual se adquiriam conhecimentos mínimos indispensáveis ${ }^{71}$. 0 sistema de UID colocava as áreas de conhecimento no mesmo patamar e a possibilidade de formar uma visão crítica da realidade em primeiro plano $^{72}$.

(Ver na página seguinte o quadro com a matriz da proposta inicial do sistema de unidades interdepartamentais.)

Para implantar as UIDs deveriam ser superados vários impedimentos:

- "ausência de condições materiais e administrativas;

- necessidade de dedicação maior dos professores, e de formação rápida de um quadro docente em regime de dedicação integral;

- despreparo dos professores face à nova postura pedagógica;

- adaptação do currículo vigente ao sistema de UID"73.

Outras divergências dificultavam o processo, porém, a meu ver, o enriqueciam ao produzir o debate, sem o qual é impossível desenvolver consensos e dissensos no exercício de uma democracia concreta e participativa.

Uma das polêmicas, que provocou infindáveis discussões, foi sobre desenhar ou não. Uma parte dos estudantes e professores negava 0 projeto como trabalho de prancheta, propondo em seu lugar outras formas de investigação adequadas à formação do arquiteto e consideradas mais amplas e complexas. A outra parte enxergava 0 trabalho de prancheta como quase exclusivo do projeto $^{74}$.

\footnotetext{
${ }^{70}$ Freitas, Ives de, 2007, entrevista à autora.

${ }^{71}$ Ibid.

${ }^{72}$ Ibid.

${ }^{73}$ Fernandes, Ari e outros, 1976 (b): 19.

${ }^{74}$ Fernandes, Ari e outros, 1976 (b): 19. Até hoje essas visões estão presentes no ensino de arquitetura. Tem-se escutado, de professores experientes de faculdades conceituadas, a opinião de que projeto trata do "terreno para dentro", o edifício, sem interessar o que está fora. Ou que o desenho fala por si mesmo em projeto e a palavra pertence a outras áreas: premissas, objetos, levantamentos, diagnósticos não fariam parte do projeto. Na minha visão, idéias redutoras da profissão que desconsideram a relação paisagem urbana-edifício.
} 
QUADRO 10 - MATRIZ DA PROPOSTA INICIAL DO SISTEMA DE UNIDADES INTERDEPARTAMENTAIS

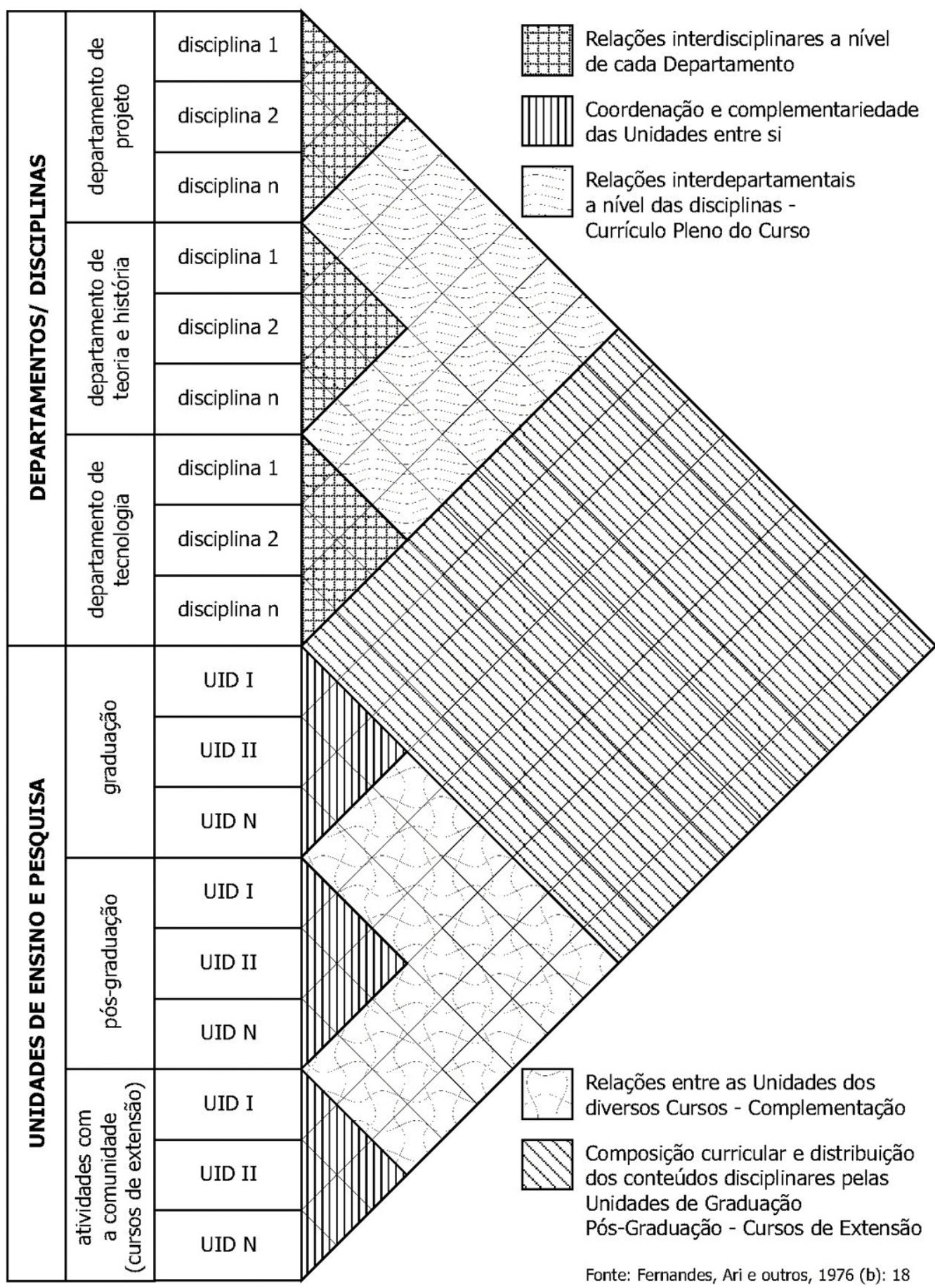


Opunha-se o pessoal do '6B' ao da 'máquina de escrever'75. De outra forma retomava-se a discussão que remetia a se o projeto era um processo de caixa preta ou de caixa transparente. Dom oposto a aprendizado. Intuição oposta a razão.

O tema das metodologias de projeto era recorrente nos anos 1960 e 1970, implícito na retomada dos debates instaurados pela Bauhaus na década de 1920. Nos cursos de arte, o debate foi similar: saber fazer, aprender a aprender e visão crítica eram vistos como propostas opostas. Após acirradas discussões, muitos setores conseguiram incluir todos esses aspectos numa metodologia sintetizadora.

Na minha visão, várias linguagens se processam de forma interrelacionada, compondo a dialética do projeto.

Mais tarde, a maioria da escola considerou o projeto como um processo no qual se incluem ambos os métodos: o "da prancheta" e o da "abstração". Porém nesse debate está implícita também a concorrência de diversos setores profissionais pelo mercado, o que hoje não é muito diferente: engenheiro civil versus arquiteto, urbanista versus geógrafo, agrônomo versus engenheiro florestal e ambos versus arquiteto paisagista. Isso não é exclusivo dessas áreas. A definição de atribuições das diferentes categorias profissionais está permeada de concorrência pelos nichos de mercado. Questões que permanecem em aberto. Nos anos 1970, o "milagre brasileiro" abria um mercado importante para planejadores urbanos, vistos como diferentes dos urbanistas. Para atender a essa demanda, as escolas de arquitetura e urbanismo deveriam formar planejadores urbanos, por isso o "quantum das Ciências Sociais" ${ }^{\prime 76}$ (nas palavras de Francisco de Oliveira) deveria incorporar-se com mais força aos currículos de graduação.

\footnotetext{
${ }^{75}$ No ambiente cotidiano do arquiteto, chamava-se de "pessoal do 6B" aos que defendiam quase que exclusivamente o uso da prancheta como instrumento de linguagem (referência à numeração do grafite para desenho); os “da máquina de escrever” utilizavam prioritariamente a linguagem verbal.

${ }^{76}$ Oliveira, Francisco, 1973: 73.
} 
As novas escolas particulares de arquitetura e urbanismo, nos chamados publicitários para seus vestibulares, argumentavam que seus currículos eram também orientados a capacitar bons arquitetosplanejadores urbanos para atender a forte demanda desse mercado. $\mathrm{E}$ contratavam cientistas políticos e sociais renomados para integrar seus quadros docentes, que despertavam nos alunos alto grau de fascínio ${ }^{77}$. Isso talvez porque o estudante de arquitetura e urbanismo era, nesses anos, muito interessado em entender o contexto político-cultural e social em que se inseria a profissão.

A inserção desses professores demandava maior espaço no currículo: a antiga competição pelo poder entre engenheiros e arquitetos nas escolas de arquitetura e urbanismo, ausente nas novas escolas, fora substituída pela disputa por espaço no currículo entre os professores provenientes das ciências sociais e políticas e os professores arquitetos. Outra discussão girava em torno da constante reprogramação, com o objetivo de afirmar e consolidar as propostas de trabalho, prática característica da FAU-SJ C, cuja origem era anterior ao sistema de UID. Os defensores da reprogramação entendiam que o método era parte integrante do modelo de ensino, como auto-avaliação e retomada constante do objeto de trabalho, valorizando-se a participação coletiva. Os opositores dessa prática a consideravam um sinal de anarquia ou de insegurança quanto à proposta das UIDs.

\section{A implantação das UI Ds na FAU-SJ C: o período de transição}

oS anos 1973 e 1974 foram implantadas cinco UIDs abordando temas passíveis de estender-se por mais um semestre.

Isso atendia à necessidade de um período de transição para compatibilizar o histórico escolar dos modelos anteriores com o novo sistema.

\footnotetext{
${ }^{77}$ Fernandes, Ari, 2007, entrevista concedida à autora.
} 
Gradativamente seriam abolidos os pré-requisitos e seqüências do currículo anterior até as UIDs se constituírem em áreas independentes de pesquisa.

O novo sistema instituía a separação do 1 ํㅡ semestre (informações básicas iniciais) e a do $10^{0}$ semestre (trabalho de graduação) e aceitava a divisão imposta pela legislação vigente em ciclos básico e profissional $^{78}$.

\section{Unidades I nterdepartamentais de Ensino e Pesquisa e os Órgãos das Escolas de Arquitetura}

Em outubro de 1974 o sistema de UID da FAU-SJ C foi apresentado no 10 Encontro de Diretores das Escolas de Arquitetura, em Brasília.

A reflexão sobre a experiência desenvolvida na FAU-SJC e sua contribuição para o ensino de arquitetura no Brasil despertou aprovação e interesse. O que convalidou a eleição de Aluísio J osé Rosa Monteiro, então diretor da FAU-SJ C, como vice-presidente da ABEA (Associação Brasileira de Escolas de Arquitetura), integrando a primeira diretoria, com a presidência de Nestor Goulart Reis Filho, diretor da FAU-USP. 0 diretor da FAU-SJ C, nessa oportunidade, integrou o CEAU (Comissão de Ensino de Arquitetura e Urbanismo) como representante das escolas isoladas ${ }^{79}$.

\section{Procurando a institucionalização}

O reconhecimento da escola e o credenciamento dos professores no MEC demandava organizar a documentação, tarefa nada fácil. Era

\footnotetext{
${ }^{78}$ Fernandes, Ari e outros, 1976 (b): 20.

${ }^{79}$ Fernandes, Ari e outros, 1976 (b): 20.

ABEA (Associação Brasileira de Escolas de Arquitetura) e CEAU (Comissão de Ensino de Arquitetura e Urbanismo) foram criadas em fins de 1973. Segundo Nestor Goulart Reis Filho a ABEA é um órgão com funções culturais, mas é prioritariamente político, na medida em que através dele se definem as diretrizes das escolas de arquitetura. Já a CEAU, criada na mesma época, tem como uma de suas funções principais levantar condições de funcionamento das
} 
preciso cumprir com o aspecto regimental, preparar a compatibilização da nova estrutura didática com as anteriores, rever cargas horárias, conteúdos curriculares e preparar condições para a renovação dos docentes, já que se previa um regime de dedicação mais intensa. Cabia à fundação mantenedora instalar e equipar os laboratórios necessários, completar o quadro mínimo de funcionários, a biblioteca e encaminhar ao Conselho Federal de Educação o regimento e processos de credenciamento de professores, após sua aprovação interna.

Porém a mantenedora vetou a aprovação devido:

- "a estrutura de poder, que propunha uma ampla participação do corpo docente e discente da escola nas decisões, reduzindo o poder absoluto pretendido pela Fundação;

- a proposta didática, que exigia um nível de qualidade de equipamentos e recursos humanos que implicariam em redução sensível das suas expectativas de lucro, comparada a um curso seriado sem dúvida mais lucrativo" $" 80$.

A mantenedora iniciou um boicote à aprovação do regimento alegando que continha uma proposta didática deficitária e utópica. 0 que contribuiu para que o diretor, arquiteto Aluisio Monteiro, se demitisse, iniciando mais uma crise na FAU-SJC. A direção foi assumida provisoriamente pelo Conselho Departamental, que levou a Minuta do Regimento ao Conselho Federal de Educação para apreciação, o que provocou um choque direto com a Fundação.

“No final de 1974 a mantenedora intervém diretamente na escola nomeando diretor pro-tempore o engenheiro eletrônico Aroldo Borges Diniz do Instituto Tecnológico da Aeronáutica (ITA). A maior parte do corpo docente é demitida e substituída às pressas acompanhada de um Regimento inadequado até para um curso de engenharia. No início de

escolas e colaborar com o MEC na fixação de diretrizes nesse campo. Depoimento em CJ Arquitetura $\mathrm{n}^{\circ}$ 4, 1974: 14.

${ }^{80}$ Fernandes, Ari e outros, 1976 (b): 20-21. 
1975 esse regimento é aprovado pela Fundação e enviado imediatamente ao MEC ${ }^{\prime \prime 1}$.

A intervenção foi derrotada pela imediata mobilização estudantil. O MEC designou a $\mathrm{CEAU}^{82}$ (Comissão de Ensino de Arquitetura e Urbanismo) visando salvaguardar a FAU-SJ C de uma estrutura e um regimento superados em termos de ensino de arquitetura e urbanismo.

O diretor pro-tempore, e seu corpo docente demitiram-se. A maioria dos professores partícipes da elaboração das UIDs foi novamente contratada em maio. Entre eles, foi nomeado diretor pro-tempore 0 arquiteto José Eduardo de Assis Lefèvre.

O regimento adequado às UIDs foi recolocado e o orçamento do ano, elaborado. As UIDs foram reprogramadas e abertas as inscrições. Apesar de a mantenedora continuar se recusando a assumir a escola, ela retomou os trabalhos em agosto do mesmo ano.

Nos meses seguintes, a comissão de assessoramento da CEAU constatou o cumprimento, por parte da escola, das tarefas de reorganização que Ihe competiam e o não-cumprimento da Fundação Valeparaibana de Ensino das obrigações inerentes à qualidade de mantenedora. Em conseqüência disso, a comissão da CEAU autodissolveu-se $\mathrm{s}^{83}$.

Durante o semestre letivo a escola funcionou quase sem verbas, com atrasos de pagamento dos salários de seus funcionários e sem equipamentos.

Nesse clima de instabilidade consolidou-se na prática a estrutura de UID. Afirmou-se como modelo viável pedagogicamente, aperfeiçoaramse seus mecanismos e novos conceitos foram discutidos.

\footnotetext{
${ }^{81}$ Fernandes, Ari e outros, 1976 (b): 21.

${ }^{82}$ A CEAU foi nomeada por Portaria Ministerial. Compunha-se de um representante do IAB, de diretores ou representantes de quatro ou cinco escolas (um de escola particular) e um representante do SERFHAU, para representar a demanda. É um órgão de assessoramento do Departamento de Assuntos Universitários, financiado por ele. Depoimento de Nestor Goulart Reis Filho in revista CJ Arquitetura ${ }^{\circ}$ 4, 1974: 15.

${ }^{83}$ Fernandes, Ari e outros, 1976 (b): 21.
} 
A crítica do semestre que se fechou forneceu as diretrizes para 0 semestre seguinte, permitindo a programação das UIDs para 1976, apresentada a seguir, na próxima página.

A capacidade de sobrevivência da FAU-SJ C, sob pressões externas, atingiu o limite de expectativa da fundação mantenedora, que esperava uma autodissolução da escola. Frente a essa situação, no início do ano de 1976 houve uma nova intervenção após as fracassadas tentativas de vender a escola. A Fundação Valeparaibana de Ensino, após seis anos de experiência, havia aperfeiçoado seus métodos: demitiu professores e funcionários sem substituí-los, transferiu a escola de seu prédio retirando seu espaço político de atuação, promoveu a transferência de todos os alunos e suspendeu as atividades da FAU-SJ C com o consenso do MEC ${ }^{84}$, "até que os ânimos estejam serenados".

${ }^{84}$ Fernandes, Ari e outros, 1976 (b): 22. 


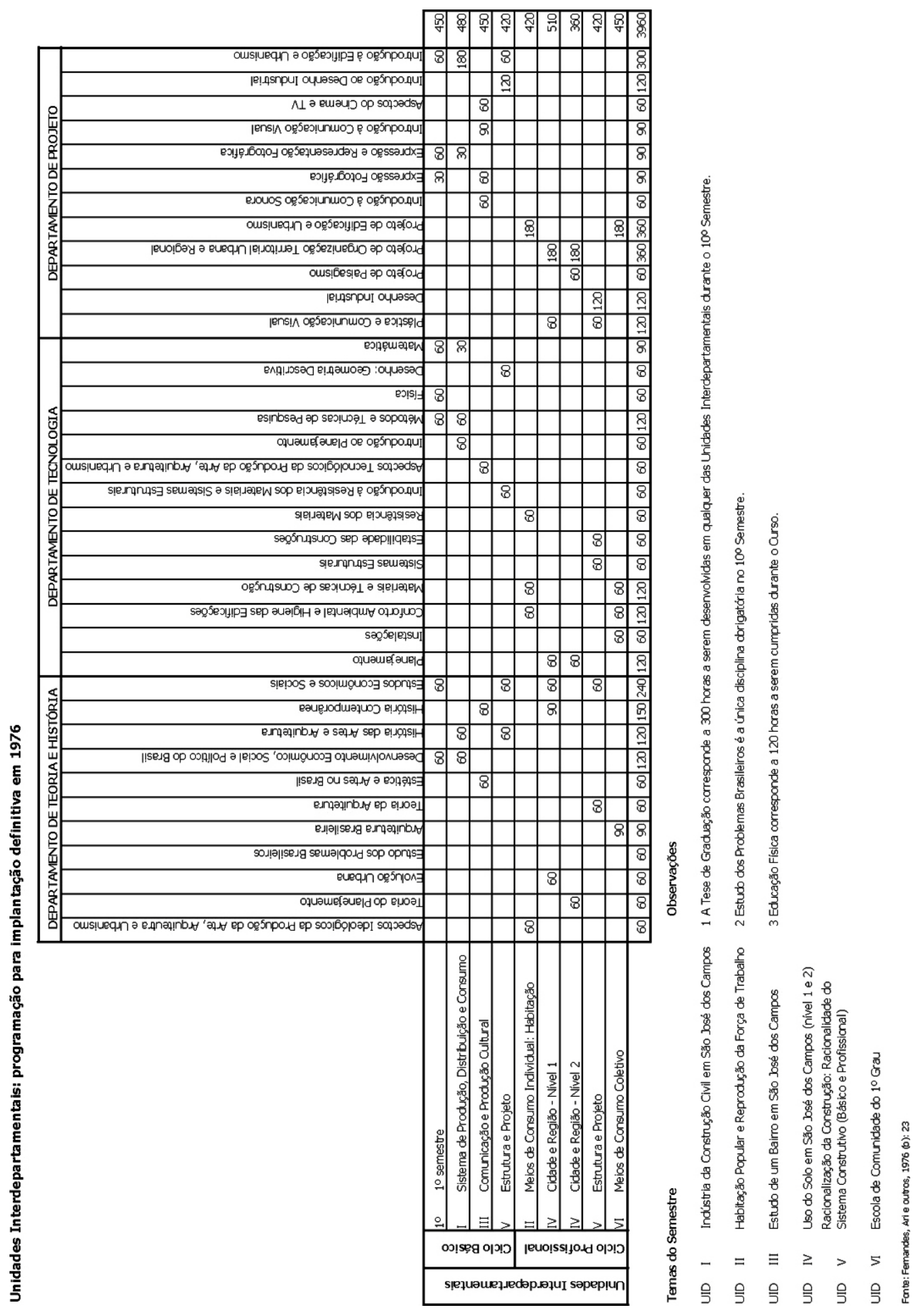



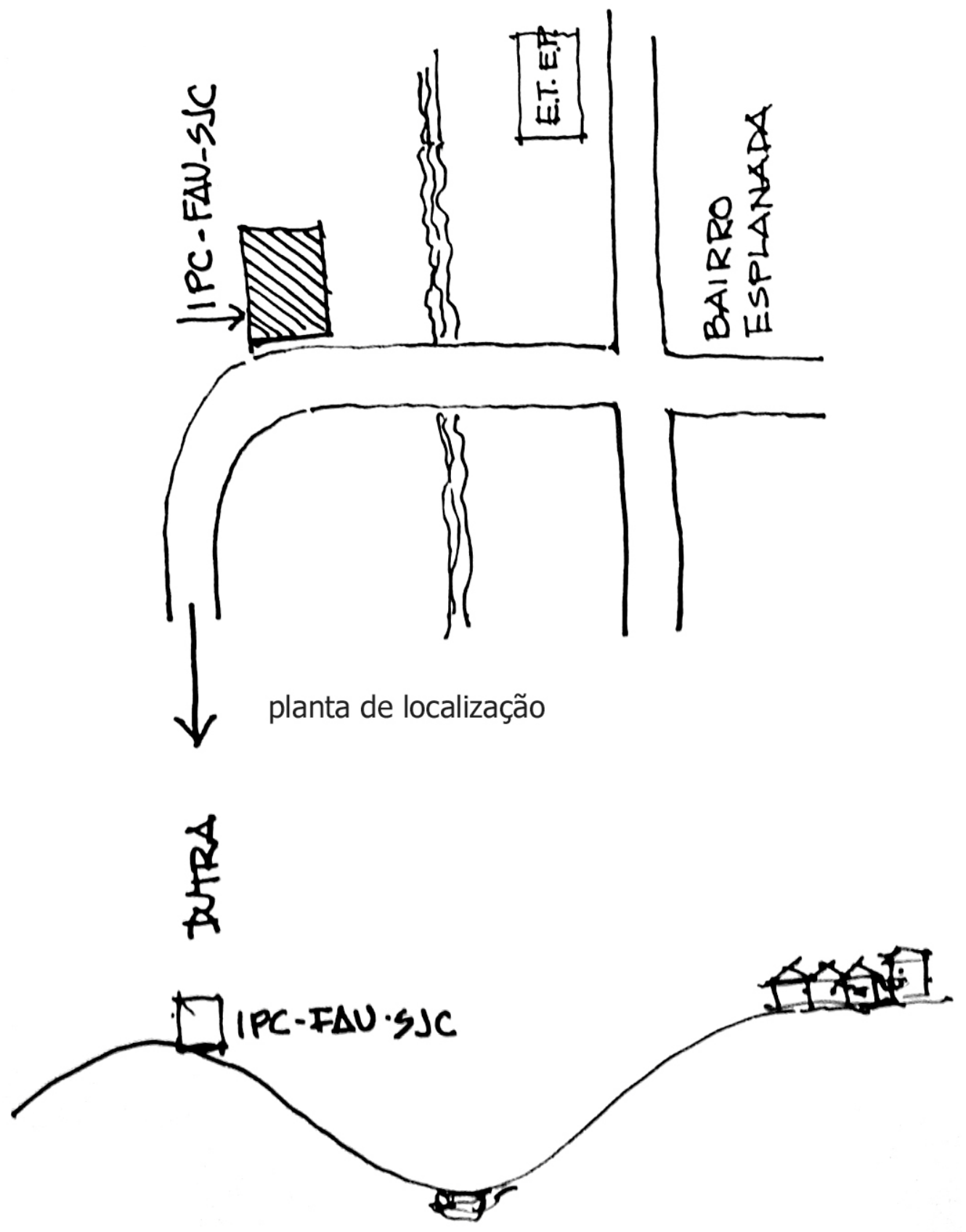

corte esquemático

Localização do antigo seminário onde funcionou o IPC-FAU-SJ C. Desenho de Regina Cardarelli, 2008. Arquivo pessoal. 


\section{CONSIDERAÇÕES FINAIS: PONTUAÇÕES PARA UM DEBATE ATUAL}

Ao remontar a um passado recente, em especial ao período de 19701976, foi possível perceber que as propostas de ensino de arquitetura e urbanismo analisadas não poderiam ser desligadas da situação política, econômica, social e cultural de cada país onde se desenvolveram. Porém, longe de se tratar de um reflexo mecânico, o contexto não apareceu só como referência, mas também como dialética permanente na construção dos processos específicos da arquitetura e do urbanismo e seu ensino, sendo ao mesmo tempo produto e processo das relações de força existentes nos diferentes momentos em que se desenvolveram.

Nos casos da FAU-SJC e do Taller Total da FAU-UNC, com forte referência da Bauhaus, os planos de estudos propunham construir uma vivência pedagógica dinâmica e interativa combinada com uma prática participativa do arquiteto urbanista.

As experiências analisadas neste trabalho são expressão do debate sobre arquitetura e urbanismo e seu ensino realizado na América Latina e no mundo nos anos próximos a 1960. Nesse debate incluía-se a luta por um ensino crítico, o que se verifica, por exemplo, nas recomendações da V Conferência Latino-Americana de Faculdades de Arquitetura (Clefa), que afirmava que a Universidade profissionalizante alienou sua capacidade real de gerar conhecimento e cultura e que, para inverter essa realidade, os cursos não deveriam se organizar em torno das profissões, mas com base na construção do conhecimento, para o que se faz necessário a autonomia acadêmica, econômica e administrativa. 
Nos anos 1960 e 1970 muitos docentes e estudantes entendiam que a construção de conhecimentos se relacionava intimamente com responsabilidade social e assumiam, assim, o papel do intelectual compromissado com a realidade sociopolítica, relacionando teoria e pratica. No campo da arquitetura e urbanismo, essa posição é uma clara referência à Bauhaus, revalorizada nesse período na América Latina e no mundo.

Existiam duas premissas básicas compartilhadas tanto pela Bauhaus durante a República de Weimar, de 1919 a 1933, quanto pela FAU-SJ C, no Brasil, e pelo Taller Total da FAU-UNC, na Argentina, cujas experiências se desenvolveram entre 1970 e 1976, períodos conturbados de sua historia, com suas particularidades:

- A arquitetura e urbanismo é uma profissão principalmente social.

- O seu ensino deve partir da análise da sociedade e suas necessidades, numa gestão democrática e participativa.

Nos anos 1970 estavam presentes também, como idéias fortes, a busca de metodologias de projeto, e discutiam-se os novos perfis de arquitetos, definidos por sua posição na produção de arquitetura e urbanismo.

Essas experiências foram possíveis devido ao ambiente políticointelectual de efervescência, de ativa participação de estudantes e docentes, que o contexto repressivo não conseguiu silenciar. Pela época e contexto em que se desenvolveram, constituíram-se em resistência às formas autoritárias de governo, tanto no país quanto nas universidades onde a relação de forças o permitiu, alcançando mais visibilidade nas FAUs UnB e SJ C, no Brasil, e na FAU-UNC, na Argentina. Revelaram-se, neste doutorado, experiências de ensino de arquitetura e urbanismo que deram respostas criativas, enriquecedoras e inovadoras, em gestões democráticas e participativas, às contradições constantes da dialética arquitetura-sociedade.

Essas propostas demonstraram que é possível integrar a participação individual e a coletiva, quando há objetivos comuns e a capacidade real 
de exercer coletivamente influência nas decisões, constituindo o que é geralmente designado como projeto participativo, o que exige 0 estabelecimento de canais de comunicação implícitos no processo de ensino.

A presença da equipe de Pedagogia no Taller Total da FAU-UNC demonstrou sua importância na estruturação e no apoio quotidiano a um curso de arquitetura e urbanismo, em especial na contribuição e assessoramento à formação docente entendida como processo continuo. Este requer, entre outras atividades específicas, a realização de avaliações com base em critérios e procedimentos científicos - interrelacionando a prática e a teoria - para possibilitar o amadurecimento e re-desenho do projeto pedagógico, quando necessário, e a relação ensino-aprendizagem.

A complexidade dos diferentes saberes leva a pensar na necessidade da comunicação com outras disciplinas, entre elas as Ciências da Educação. O arquiteto docente, certamente, quando assume a função do ensino, precisa de outros saberes não incluídos no currículo de graduação e dificilmente poderia dominar o saber específico das Ciências da Educação. Resgata-se, então, a importância da participação de equipes pedagógicas interagindo no quotidiano dos processos de ensino-aprendizagem de arquitetura e urbanismo.

É necessário levar em consideração que em certas condições conjunturais, essas experiências inovadoras, abrindo brechas, podem vir à tona. Porém, pelo fato de as condições não serem estruturais, 0 período de duração dessas experiências, assim como seu grau de inovação, criatividade e visão critica podem mudar devido à relação de forças existente em cada momento.

As experiências descritas neste trabalho, em especial as da FAU-SJ C, com suas propostas do Instituto de Projeto e Comunicação, do Ateliê e das Unidades Interdepartamentais, e as do Taller Total da FAU-UNC, contribuem de maneira importante para um debate atual de arquitetura 
e urbanismo e seu ensino. Elas demonstram a viabilidade de incorporar os diversos aspectos da criatividade individual, coletiva e interdisciplinar, contemplando a participação como parte integrante do processo projetual. Também inspiram a busca de caminhos para a construção de uma dialética entre os movimentos populares de inserção social e 0 processo de ensino de arquitetura e urbanismo visando discutir suas diretrizes.

Essas propostas curriculares contêm o esforço de superação de ensino fragmentado, de inter-relação e integração dos conteúdos numa busca interdisciplinar, seja por níveis, seja no internível proposto pelo Taller Total.

Está implícita nelas uma visão da ação projetual como resultado da confluência e inter-relação de todas as disciplinas que compõem 0 currículo dos cursos. Verifica-se também que no debate sobre ensino de arquitetura e urbanismo está implícita a luta entre dois paradigmas: 0 da Universidade como crítica de si mesma e da sociedade e o da Universidade como grande empresa, que funciona com a idéia do saber visto como mercadoria.

Os currículos e seu projeto pedagógico têm-se definido como produtos da relação de forças desses paradigmas, pontuada pelas relações econômicas de produção, que relegam, na maioria das vezes, ao segundo plano questões importantes do ensino de arquitetura e urbanismo, como as relacionadas a políticas urbanas, participação popular e de percepção dos lugares de vida.

É importante recuperar um diálogo que permita construir, no ensino de arquitetura e urbanismo - indissoluvelmente ligados à paisagem, entendida como processo e produto da ação dos homens - , uma interdisciplinaridade em torno da ação projetual. Este é um desafio proposto para a atualidade.

Entende-se também necessário reconquistar o sentido do habitat ampliado, que permeou o debate latino-americano e mundial nos anos 
1969-1970 e que teve marcada visibilidade no processo do Taller Total, na FAU-UNC.

Cada caso, com suas características próprias, contém a busca de um habitat ampliado ou uma relação cognitiva com os lugares de vida que constrói o sentido de pertencimento e identificação - , possibilitando sua apreensão ao entender que habitar não é só possuir uma casa, mas pertencer a um lugar.

Essa visão questiona o paradigma racionalista na arquitetura e urbanismo, que encontra na sobrevalorização do planejamento uma das suas expressões, entendendo que a forma poderia organizar a sociedade.

O desenvolvimento do Brasil, como o de outros países latinoamericanos, entre eles a Argentina, atende a um processo desigual e combinado, onde convivem formas avançadas e arcaicas de produção. Isso se revela nas formas de produção da arquitetura e urbanismo e da paisagem, que ora se apóiam no 'exercito de reserva', sem qualificação técnica, ora no mais alto nível de tecnologia (neste caso, em baixíssima proporção). Por isso entendo que o ensino de arquitetura e urbanismo deva atender a essa complexa demanda com alto grau de flexibilidade, abrangência e profundidade.

Os modos de construir o conhecimento arquitetônico e urbanístico demandam a interdisciplinaridade e a construção conjunta do conhecimento. Debater as interrogações de: como, por que, para que, para quem, com quem e o que ensinar e aprender é hoje imprescindível na complexa realidade a ser atendida.

Do ponto de vista da educação, Paulo Freire, Nidia Nacib Pontuschka e Maria Saleme de Burnichón, entre outros,concordam com Gramsci quando afirmam que a participação realmente ativa do estudante somente pode existir se o processo de ensinar e aprender estiver ligado à vida, tendo uma visão critica, processo que se entretece com a construção da cidadania. 
Referências Bibliográficas

ALBUQUERQUE, Roberto Portugal. Uma escola de Arquitetura - FAUUSP, edifício e ensino. São Paulo: FAU-USP (dissertação de mestrado), 2004.

ALENCAR, Francisco; CARPI, Lucia; RIBEIRO, Marcus. História da Sociedade Brasileira. Rio de Janeiro: Ed. Ao livro técnico, 1979.

ARANTES, Pedro F. Arquitetura Nova. São Paulo: Ed. 34, 2002. ARANGO, Diana Soto; J ARDILINO, Rubens Lima. Políticas universitárias em Latinoamérica: História e Perspectiva. São Paulo: ed. Emblema, 2006.

ARA-CEAU (Agrupación rerformista de Arquitectura - Centro de Estudantes de Arquitectura e Urbanismo). Objetivos de un plan de estudios. Córdoba (Argentina). Dirección General de Publicaciones de la Universidad Nacional de Córdoba, 1963.

ARGAN, Giulio Carlo. Walter Gropius e a Bahaus. Lisboa: ed. Presença Martins Fontes, 1984.

. Projeto e destino. São Paulo: Ática, 2001.

ARTIGAS, J oão Batista Vilanova. Caderno dos riscos originais da Faculdade de Arquitetura e Urbanismo (fac-símile). São Paulo: FAUUSP, 1992.

ARTIGAS, J oão Batista Vilanova. Caderno dos riscos originais: projeto do edifício da FAU-USP na Cidade Universitária, coordenação de Roberto Portugal Albuquerque. São Paulo: FAU-USP, 1998. 
BARONE, Ana Claudia Castilho. Team 10:arquitetura como crítica. São Paulo: Annablume: FAPESP, 2002.

BASTOS ,Paulo e outros. Documento Básico Justificativo do IPC .São Jose dos Campos: s/ editora,1971

BETTO, Frei. Batismo de Sangue. Rio de Janeiro: Civilização Brasileira, 1982.

BONDUKI, Nabil. Origens da habitação social no Brasil. São Paulo:

Estação Liberdade, 1998.

BOUCINHAS, Caio. Projeto participativo na produção de espaço público.Tese de doutorado,São Paulo: FAU-USP,2005

BRENNAN, J . El Cordobazo. Las guerras obreras en Córdoba, 1955-1976. Buenos Aires: Ed. Sudamericana, 1996

BRENNAN, J . e GORDILLO M. Protesta obrera, rebelión popular e insurrección urbana em La Argentina: El Cordobazo): Centro de Estúdios Avanzados - UNC . Estúdios no. 4, Córdoba, (Argentina ), Jul/ Diciembre 1994.

COLQUHOUN, Alan. Modernidade e tradição clássica. São Paulo: CosacNaif, 2004.

DEPARTAMENTO DE TECNOLOGI A . Texto básico para discussão no Fórum de Debates. São J ose dos Campos: s/editora ,1973.

DELICH, F. Crisis y Protesto Social. Córdoba: FAU-UNC, 1969.

DIRECCIÓN DE PLANEAMIENTO. Departamento de estatística.Sintesis estatística universitaria 1968-1976. Cordoba,(Argentina): UNC,1976.

ELKIN, Benjamín. Taller total, una experiencia educativa democrática en la Universidad Nacional de Córdoba. Córdoba (Argentina): ed. Ferreyra, 2000.

FAU-HISTÓRICO, revista O Desenho, São Paulo, n 1, 1970. 
FERNANDES, Ari e outros. Pratica- Investigação in Anais do IX Congresso Brasileiro de Arquitetos. São Paulo: Instituto de Arquitetos do Brasil, 1976. . Prática-investigação: um processo de trabalho em São J osé dos Campos. S/ editora,1976,(b) FERNANDES, Ari. Capitulo IV. C/ Arquitetura, revista de planejamento e construção,São Paulo, n.4,1974.

FERREIRA CENTENO, Raul. El Croquis. Córdoba (Argentina): FAU-UNC, 1973.

FONTAN, Juan Carlos; NOVILLO CORVALAN, Marcelo. La facultad de Arquitectura e Urbanismo. Argentina: Universidad Nacional de Córdoba, 1971.

FRAMPTON, Kenneth. Historia Crítica de la Arquitectura Moderna. México: Editorial Gustavo Gili, 1983. Evolución del concepto de vivienda 1870-1970 . revista Summa, no.86, Buenos Aires, fevereiro. 1975. FREIRE, Paulo. A pedagogia do oprimido. Rio de Janeiro: Paz e Terra, 1970.

GAITE, A. Reflexões acerca de la enseñanza de la arquitectura .Revista Summa Universitaria no 1. Buenos Aires,no.1, 1986.

GRAEFF, Edgard A. Sobre a formação do arquiteto. Texto copiografado, s/ ed. 1970.

HOBSBAWM, Eric. Mayo de 1968, in Gente poco corriente. Barcelona: ed. Crítica, 1999.

KOOP, Anatole. Quando o moderno não era um estilo e sim uma causa. São Paulo: Nobel - Edusp, 1990. 
KOURY, Ana Paula. Grupo Arquitetura Nova: Flávio Império, Rodrigo Lefèvre e Sérgio Ferro. São Paulo: Edusp, Romano Guerra, Fapesp, 2003.

LAMFRI, Nora Z. Urdimimbres. El Taller Total: Um estúdio de caso Cordoba, (Argentina) :Centro de Estúdios Avanzados.UNC (Dissertação de mestrado),2007

LEFÈVRE, Rodrigo. Projeto de acampamento de obra: uma utopia. São Paulo: FAU-USP (Dissertação de Mestrado), 1981. . 0 arquiteto assalariado. Revista Módulo n 66. São Paulo,no.66, setembro de 1981.

LI MA, Mayumi Watanabe de Souza. Arquitetura e Educação. São Paulo: Studio Nobel, 1995.

LIMA, Mayumi Watanabe de Souza. Introdução. CJ Arquitetura ,revista de planejamento e construção,São Paulo, n.4,1974.

LUCCHESE, Maria Cecília. Curam-se cidades: uma proposta urbanística da década de 70. São Paulo: FAU-USP (Dissertação de Mestrado), 2004. LURIA, A. R. Desenvolvimento cognitivo. São Paulo: ed. Ícone, 1990. MACHADO, Alexander da Silva. Uma reflexão sobre a Faculdade Interamericana de educação (1970-1977) in ARANGO, Diana de Soto; J ARDI LINO, Rubens L. Políticas Universitarias en Latinoamérica. São Paulo: Emblema, 2006.

MARIANO, Cassia. Preservação e paisagismo em São Paulo: Otavio Augusto Teixeira Mendes. São Paulo: Annablume/ Fapesp/ Fundação Oscar Americano, 2005.

MARICATO, Ermínia. Habitação e cidade. São Paulo: Atual, 1997. Política Habitacional e Regime Militar: do milagre militar à crise econômica. Petrópolis: Vozes, 1976. 
MARTI NEZ PAZ. El sistema educativo nacional - Formación, Desarrollo, Crisis. Córdoba: UNC.,1986.

MARTINEZ, Silvia Alicia. Memória de Professores: Experiências pedagógicas universitárias na Argentina (1968-1976).Rio de J aneiro: PUC-RJ ,2000.

- Ensaio de construção de uma Universidade

Critica: A "Oficina Total" de Arquitetura e Urbanismo de Córdoba.(Argentina,1970-1976). Trabalho apressentado à 23으 Reunião Anual.(ANPED), Caxambú,MG ,2000.

MARTINS, C. B. (org.). Ensino Superior Brasileiro, transformações e perspectivas. São Paulo: Brasiliense, 1988.

MEYER, Hannes. El arquitecto en la lucha de clases e otros escritos. Barcelona: Editorial Gustavo Gili, 1972.

MILLAN, Carlos Barjas. O Ateliê na formação do Arquiteto. (1962), revista Sinopses, São Paulo, número especial ,1993,.

NASELLI,Cesar. Homenaje al arquitecto Carlos Eduardo David. Revista Summa, Buenos Aires, n.154,1984.

NOBRE,Ana Luisa. Lucio Costa,o primeiro verso. Revista AU Arquitetura urbanismo, São Paulo, n.38, out./Nov.1991.

OLIVEIRA, Francisco de. Crítica à razão dualista - O Ornitorrinco. São Paulo: ed. Boitempo, 2006. . Ensino de Arquitetura, in revista Opção n 2. São José dos Campos: FAU-SJ C, dezembro 1972. . O vício da virtude. Revista Novos Estudos.

CEBRAP, São Paulo, no 74, março. 2006.

OLIVEN, Arabela Campos. A paroquialização do ensino superior: classe média e sistema educacional no Brasil. Petrópolis: Vozes, 1990. 
PANERAI, Philipe R.; CASTEX, Jean; DE PAULE, J. Charles. Formas Urbanas: de la manzana al bloque. Barcelona: Editorial Gustavo Gili, 1986.

PEREIRA, Miguel Alves. Arquitetura: cultura, formação, prática e política profissional. São Paulo, Pini, 2005.

PEREIRA, Raul. O sentido da paisagem e a paisagem consentida. São Paulo: FAUUSP (Tese de Doutorado), 2006.

PRONSATO, Sylvia Adriana Dobry. Arquitetura e paisagem - projeto participativo e criação coletiva. São Paulo: ed. Annablume, Fapesp, Fupam, 2005.

REBORA, Luis. FAU - Cronologia Testimonial. Córdoba: FAU-UNC, 1991. REIS, Nestor Goulart. Depoimento. CJ Arquitetura, revista de planejamento e construção,São Paulo, n.4,1974.

RESCHILIAN, Paulo Romano. A produção de assentamentos precários em São José dos Campos: a favela Nova Tatetuva, um exemplo para análise. São Paulo: FAUUSP (Tese de Doutorado), 2004.

RIBEIRO, Darcy. Universidade para quê? Brasília: UnB, 1986.

RICHARD, Leonel. A República de Weimar. São Paulo: Companhia das Letras, 1988.

RODRIGUES, Antonio J acinto. A Bauhaus e o ensino artístico. Lisboa: Ed. Presença, 1989.

SANTOS, Boaventura de Sousa. Pela mãe de Alice - O social e o político na pós modernidade. São Paulo: ed. Cortez, 1997.

SANTOS, Maria Cecília Loschiavo (org). Maria Antonia: uma rua na contramão. São Paulo: Nobel, 1988.

SANTOS, Milton. Encontro Nacional de Didática e Prática de Ensino (palestra), in volume III ed. XI ENDIPE, Águas de Lindóia, São Paulo: 1998. 
SUPLEMENTOS SUMMA. Conjuntos habitacionais. Recopilação dos números 36/49/71/72/76/78. Buenos Aires: 1975.

SEGRE, Roberto. Arquitetura e Urbanismo da Revolução Cubana. São Paulo: Studio Nobel, 1991.

SEVCENKO, Nicolau. A corrida para o século XXI. São Paulo: Companhia das Letras, 2001.

SILVA J r., J oão dos Reis; SGUISSARDI, Valdemar. Novas faces da educação superior. Bragança Paulista: Edusf, 1999.

(org.) Políticas públicas para a Educação Superior.

Piracicaba: editora Unimep, 1997.

TAFURI, Manfredo. Para uma crítica da ideologia contemporânea.

Barcelona: Gustavo Gili, 1972.

TARAZONA, Alvaro Acevedo. Conflicto e reforma universitaria en América Latina, in ARANGO, Diana Soto; JARDI LINO, R. L., Políticas Universitarias en Latinoamérica. São Paulo: Emblema, 2006.

TESTA,Clorindo; SOLSONA, J J .; IBARLUCIA,A.; GRICHENER,S.;

AIZEMBERG,L.,Concurso Summa 1967/ 68. Summa, Buenos Aires,no. 13,out. 1968.

VAN EICK, Aldo. A história de uma outra idéia. Revista Fórum no 7. Amsterdã: 1959.

VIEIRA, Sofia Lerche, O (dis)curso da (re)forma universitária. Fortaleza: Editora UFC/PROED, 1962. Labyrinthine Clarity. World Architecture, no 3, 1966.

VIGOTSKY, L. S. A formação social da mente. São Paulo: Martins Fontes, 1989. . Pensamento e linguagem. São Paulo: Martins Fontes, 1989. 
VOLPI, Jorge. La imaginación y el poder: una historia intelectual de 1968. México: Era, 2001.

XAVIER, Alberto (org.). Depoimento de uma Geração. São Paulo: ABEA/ FVA/ Pini, 1987.

XAVIER, Alberto; MIZOGUCHI, I van. Arquitetura Moderna em Porto Alegre. São Paulo: FAU-UFRGS - Pini, 1987.

ZACCARELLI, O.Vender. Población Ignácio Centeno, Valparaiso.

Summa, Buenos Aires, No. 11,abril, 1968.

ZANETINI, Siegbert (org.). Cadernos Brasileiros de Arquitetura no 8. São Paulo: Editora Projeto, sem data.

\section{Sites}

CASTRO, André Augusto. Disponível em

<www.unb.br/acs/unbagencia/ago05-76>. Acesso em 19 ago.2007.

GASPAROTO, Rafael. Disponível em

<www.radiobras.gov.br/especiais/golpe64/golpe64_unb2htm?materia= 179996\&editoria>. Acesso em 29 ago.2007.

TAHAN, Lilian. Disponível em

<clipping. planejamento.gov.br/Noticias. asp?NotCod=113299>. Acesso em 18 ago.2007.

<www.arte.unb.br/ida_historia/65a70.htm>. Acesso em 20 ago.2007.

<www.arte.unb.br/ida_historia/estatuto70.htm>. Acesso em 20 ago.2007.

<www.unb.br/fau/guia/historico.htm>. Acesso em 19 ago.2007. 
Bibliografia

ARACY, Amaral. Arte para quê? São Paulo: Nobel, 1984.

ARANTES, Otília. O lugar da arquitetura depois dos modernos. São Paulo: Edusp, 1993.

ARTIGAS, J oão Batista Vilanova. A cidade é uma casa. A casa é uma cidade (exposição). São Paulo: Almada, Casa da Cerca e Fundação Vilanova Artigas, 2001.

ARTIGAS, J oão Batista Vilanova. Contribuição para o Relatório sobre Ensino de Arquitetura. UIA-UNESCO, 1974, in Sobre a História do Ensino de Arquitetura no Brasil. São Paulo: Associação Brasileira de Escolas de Arquitetura, 1977.

BONDUKI, Nabil. Construindo territórios da Utopia: a luta pela gestão popular em projetos habitacionais. São Paulo: FAU-USP (Dissertação de mestrado), 1986.

CASARINI RATTO, M. Teoria e Diseño Curricular. México: Itesm, 1999.

ENGELS, F. A questão da Habitação. 1872 (várias edições).

FAGGIN, Carlos Augusto Mattei. O ateliê na formação do arquiteto: uma análise crítica do documento apresentado por Carlos Millan na FAU-USP em 1962, in revista Sinopses, 1993 (número especial).

FANDINHO, Lilian. La enseñanza del Proceso de Diseño. Córdoba, Argentina: FAU-UNC, 2005.

FANDINHO, Lilian. El aprender en la Universidad. Córdoba, Argentina: IEU-UNC, 1990.

FERNANDES, Florestan. Brasil, em compasso de espera. São Paulo: editora Hucitec, 1980. 
A revolução burguesa no Brasil. Rio de J aneiro:

Zahar, 1975.

FERRO, Sérgio. Arquitetura Nova (1968). Arte em revista $n^{\circ} 4$. São Paulo: ed. Kairos, 1980.

. Reflexões para uma política na arquitetura (1969/70).

Arte em revista $\mathrm{n}^{\circ}$ 4. São Paulo: ed. Kairos, 1980.

. O Canteiro e o Desenho. São Paulo: ed. Projeto/ IAB,

1979.

- O ensino do Desenho: nota sobre o ensino de

Arquitetura, revista Arquitetura e Urbanismo. São Paulo, n 5, abril . 1986.

FREIRE, Paulo. Política e educação. São Paulo: ed. Cortez, 1997. - Pedagogia da autonomia. Rio de Janeiro: Paz e Terra, 1997. . A educação na cidade. São Paulo: ed. Cortez, 1999.

FREITAS, I ves de; MARTINS, Maria Lucia. A crise nas Belas Artes. revista Projeto, São Paulo. $n^{\circ}$ 88, janeiro . 1986.

GOHN, Maria da Glória. A educação não formal e a escola comunidade. revista Eccos, São Paulo,, V.6 n² 2, 2004.

GRAEFF, Edgard A. Aprendizado de Arquitetura: uma experiência na Universidade de Goiás. revista Projeto .São Paulo, n 54, agosto .1983. . Essa longa saga de frustrações, depoimento ao Conselho Federal de Educação, revista Arquitetura e Urbanismo. n ${ }^{\circ} 5$, abril de 1986.

GROPIUS, Walter. Impressões sobre a instrução de um arquiteto. Brasil Arquitetura Contemporânea, n 8, 1956. 
HARVEY, David. O trabalho, o capital e o conflito de classes em torno do ambiente construído nas sociedades capitalistas avançadas, in revista Espaço e Debate n 6. São Paulo: ed. Cortez, 1982.

LEFEBVRE, Henry. La production de l'espace. Paris: Anthropos, 1986.

LEFÈVRE, Rodrigo. Notas de um estudo sobre os objetivos de ensino da arquitetura e meios para atingi-los em trabalho de Projeto. São Paulo: FAU-USP, 1977.

LI MA, Mayumi Watanabe de Souza. A cidade e a criança. São Paulo: Nobel, 1989.

MANACORDA, Mario Alighiero. Marx e a Pedagogia Moderna. São Paulo: ed. Cortez, 1996.

MARICATO, Ermínia. Loteamentos clandestinos, revista Módulo n 60 . São Paulo: setembro . 1980. . Metrópole na periferia do capitalismo. São Paulo:

Hucitec, 1996.

MAGNOLI, Miranda. Entrevista a SILVA, J onathas Magalhães Pida. revista Paisagem e Ambiente. $\mathrm{n}^{\circ} 21$. São Paulo, No. 21, FAU-USP, 2006.

MARX, Karl. Manuscritos Económico Filosóficos de 1944 in Os pensadores: Marx v. 02. São Paulo: Nova Cultura, 1998.

MÉSZÁROS, István. A educação para além do capital. São Paulo: ed. Boitempo, 2005.

MÉSZÁROS, István. Marx: a teoria da Alienação. São Paulo: ed. Boitempo, 2005.

MOTTA, Flávio. Subsídios para Relatório sobre Ensino de Arquitetura (UIA-UNESCO), in Sobre a História do Ensino de Arquitetura no Brasil. São Paulo: Associação Brasileira de Escolas de Arquitetura, 1977. PEREIRA LEITE, Maria Ângela Faggin. As tramas da segregação. São Paulo: FAU-USP, 1998. 
PRADILLA, Emilio; JIMÉNEZ, Carlos. Arquitectura, Urbanismo e dependência neocolonial. Buenos Aires: Ediciones Siap - Planteos, 1973.

SANTOS, Milton. Pensando o espaço do homem. São Paulo: Hucitec, 1982.

SANTOS JUNIOR, W. R. O currículo mínimo no ensino de arquitetura e urbanismo no Brasil: 1969-1994. São Paulo: FAU-USP (Tese de Doutorado), 2001.

SARLO, Beatriz. Paisagens Imaginárias: Intelectuais, Arte e Meios de Comunicação. São Paulo: Edusp, 2005.

SUBIRATS, Eduardo. Da vanguarda ao pós-moderno. São Paulo: Nobel, 1987. 